Contom $=$

\begin{tabular}{|c|c|c|}
\hline ENGINEERING CHANGE NOTICE & Pooe 1 of 2 & $\begin{array}{l}\text { 1. ECN } Q \because 599 \\
\text { Proj. }\end{array}$ \\
\hline
\end{tabular}

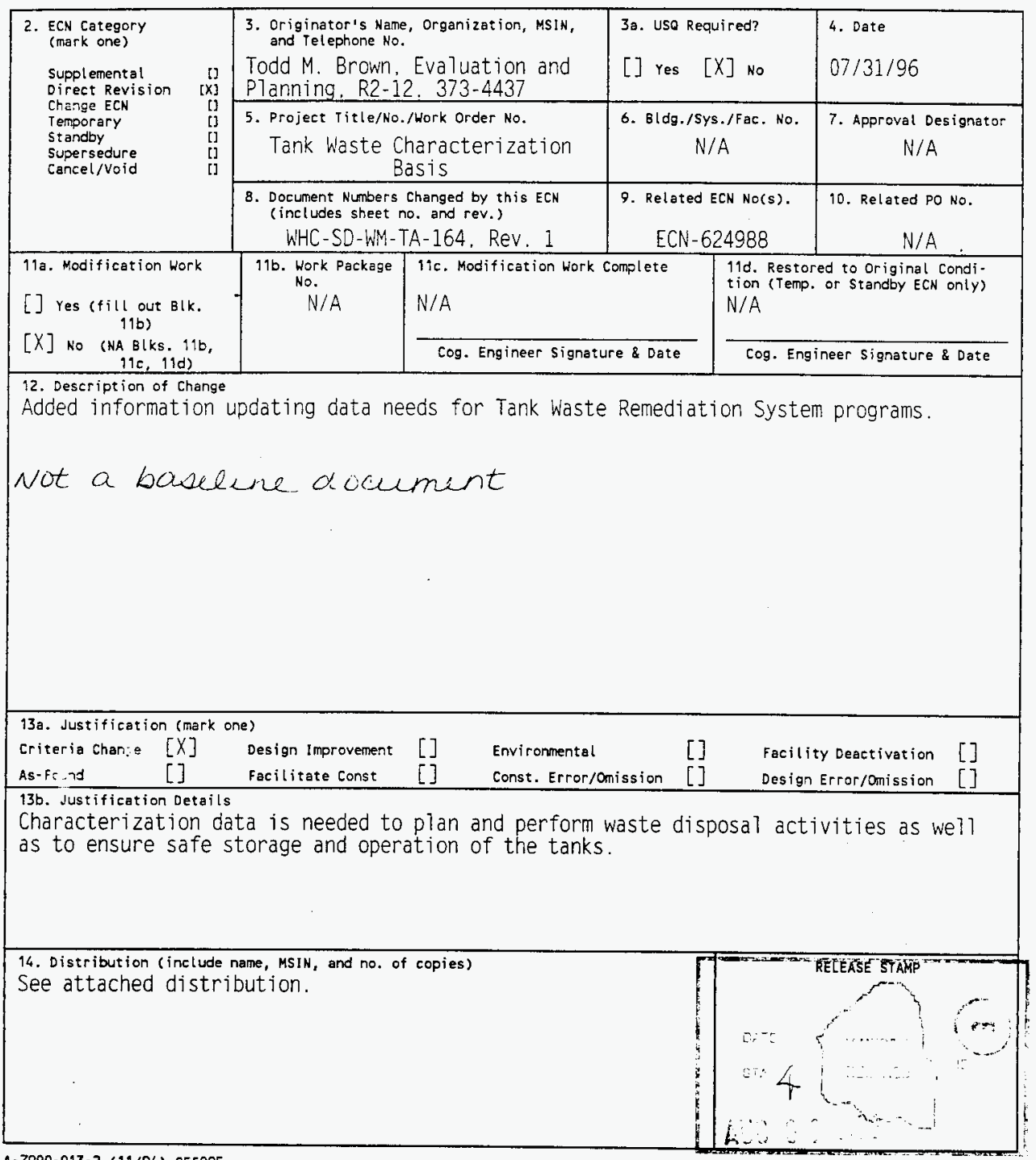




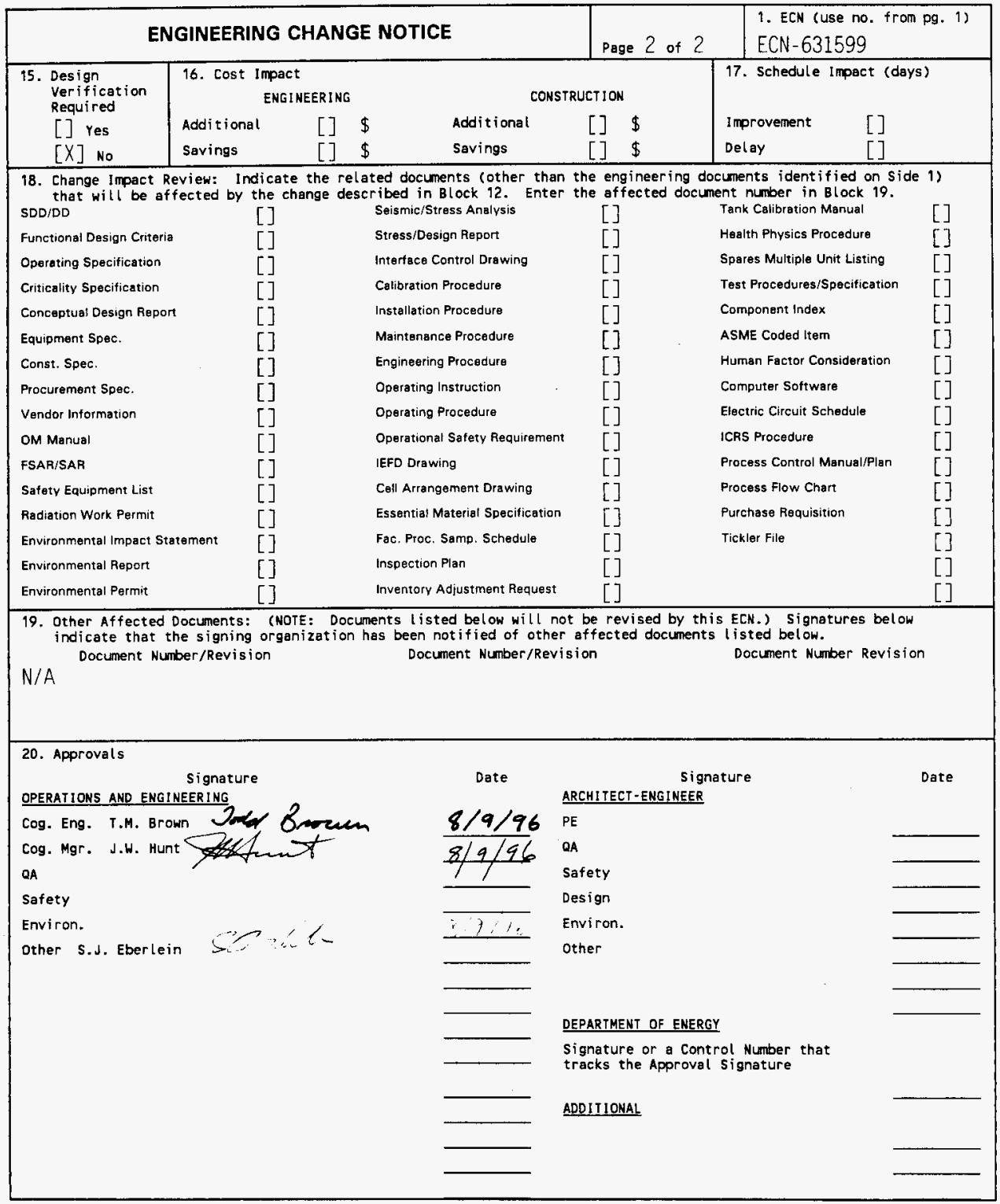




\title{
Tank Waste Characterization Basis
}

\author{
Todd M. Brown
}

Westinghouse Hanford Company. Richland, WA 99352

U.S. Department of Energy Contract DE-AC06-87RL10930

EDT/ECN: $\quad$ ECN-631599

Org Code: 79200

B\&R Code: EW 3120074
UC: 2070

Charge Code: N4G6A

Total Pages: 200

Key Words: Characterization. Safety Issues, Strategy, Data Quality objectives, Safety Screening. Prioritization. Matrix, Criteria. Constraints

Abstract: This document describes the issues requiring characterization information. the process of determining high priority tanks to obtain information, and the outcome of the prioritization process. In addition, this document provides the reasoning for establishing and revising priorities and plans.

TRADEMARK DISCLAIMER. Reference herein to any specific comercial product, process, or service by trade name, trademark, manufacturer, or otherwise, does not necessarily constitute or imply its endorsement, recommendation, or favoring by the United States Government or any agency thereof or its contractors or subcontractors.

Printed in the United States of America. To obtain copies of this document, contact: HHC/BCS Document Control Services, P.0. Box 1970, Mailstop H6-08, Richland WA 99352, Phone (509) 372-2420; Fax (509) $376-4989$.
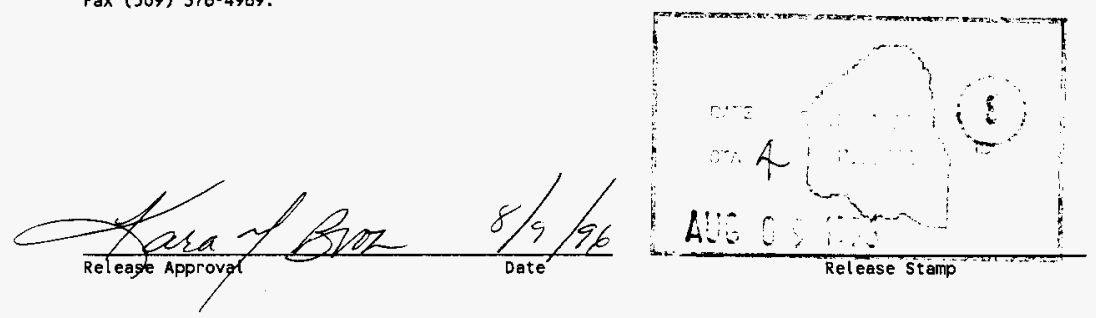

\section{Approved for Public Release}


RECORD OF REVISION

(1) Document Number

WHC-SD-WM-TA-164

Page 1

(2) Title

TANK WASTE CHARACTERIZATION BASIS

CHANGE COHTROL RECORD

(3) Revision (4) Description of Change - Replace, Add, and Delete Pages (7) EDT $612695,06 / 29 / 95$

0

1 RS Added data requirements for waste disposal. ECN 624988, 08/28/95.

2 R. Incorporate per $\mathrm{ECN}-631599$.

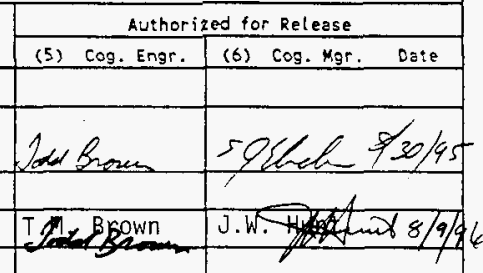




\title{
Tank Waste Characterization Basis
}

\author{
T. M. Brown \\ S. J. Eberlein \\ J. W. Hunt \\ Westinghouse Hanford Company \\ T. J. Kunthara \\ ICF Kaiser \\ Date Published \\ August 1996
}

Prepared for the U.S. Department of Energy

Assistant Secretary for Environmental Management

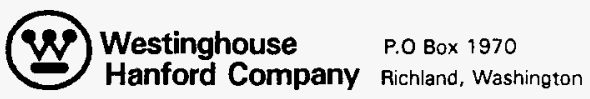

Manegement and Operations Contractor for the

U.S. Department of EnergV under Contract DE-ACO6-87RL10930

Approved for public release; distribution is unlimited 


\section{EXECUTIVE SUMMARY}

The Hanford Site has 177 underground high-level radioactive waste storage tanks in 18 tank farms. The tanks contain accumulated liquid, sludge, and saltcake wastes from more than 50 years of nuclear weapons material production activities at the Hanford Site. Several types of waste exist in the tanks, and the tank contents vary from homogeneous to highly heterogeneous. The tanks also have a variety of safety, disposal, and operational issues of varying importance associated with them.

This document establishes an approach to determine the priority of tank sampling and characterization activities and identifies high priority tanks for sampling at Hanford. The approach is based on data quality objectives (DQOs) for each issue identified:

- Flammable Gas (McDuffie 1995 - DQO is being revised to incorporate single-shell tanks)

- Organic Fuel Phenomenology (Turner et al. 1995)

- Safety Screening (Dukelow et al. 1995)

- Vapor Screening (Osborne et al. 1995, Price 1994, Mulkey and Markillie 1995, and Laws 1996)

- Vapor Space Phenomenology (DOE-RL 1996)

- Ferrocyanide (Meacham et al. 1995b)

- Privatization (DQO is being prepared)

- Process Testing: Sludge Washing (Slankas et al. 1995 and Kupfer et al. 1995)

- Process Testing: Supernatant Pretreatment (Slankas et al. 1995) 
- Retrieval (Bloom et al. 1995)

- Historical Model Evaluation (Simpson and McCain 1996)

- Evaporator (Von Bargen 1995)

- Waste Compatibility (Fowler 1995)

- Caustic Mitigation (Test plans may be used where applicable)

Evaluation criteria were established and weighted for each issue, and the tank priorities were determined following the approach outlined in this document. Priority scores for each issue were assigned by Tank Waste Remediation System (TWRS) programs, the Department of Energy - Richland Operations Office (DOE-RL), and the Washington State Department of Ecology.

Twenty seven tanks have been identified that would best support the needs of the several TWRS programs, if sampled. These 27 tanks are referred to as high priority tanks. For each of the high priority tanks, the waste phase of interest (solid, supernatant, or vapor), type of sampling required, Watch List status, and related program issues associated with it are shown in Table ES-1.

Six tanks (241-TY-103, 241-SX-104, 241-TX-111, 241-BY-105, 241-BY-103, and 241-BY-106), which were on the list of high priority tanks in the previous revision of this document, are no longer on the list. The primary reason that these tanks are no longer on the list is that they were to be sampled for the flammable gas issue; however, they are no 
Table ES-1. High Priority Tanks for Sampling

\begin{tabular}{|c|c|c|c|c|}
\hline Thin & Wosie Ihase & Sampling WYoe & Watcrithrst & Worlaes \\
\hline U-103 & Solid & Push/RGS & Hydrogen Organic & FG, OR, SS \\
\hline A-101 & Solid & Push/RGS & Hydrogen Organic & FG, OR, SS, SW, HM \\
\hline AN-103 & Solid & Push/RGS & Hydrogen & FG, SS \\
\hline AN-104 & Solid & Push/RGS & Hydrogen & FG, SS \\
\hline SX-103 & Solid & Rotary & Hydrogen Organic & OR, SS, HM \\
\hline C-104 & Solid & Push & None & OR, SS, SW, HM \\
\hline AX-101 & Solid & Rotary & Hydrogen & OR, SS, HM \\
\hline BX-110 & Solid & Rotary & None & OR, SS, SW, HM \\
\hline S-106 & Solid & Push/RGS & None & FG, SS, HM \\
\hline TX-118 & Solid & Rotary & $\begin{array}{l}\text { Ferrocyanide } \\
\text { Organic }\end{array}$ & OR, SS, SW, HM \\
\hline BY-101 & Solid & Push/RGS & None & FG, SS \\
\hline TY-102 & Solid & Rotary & None & OR, SS, \\
\hline SX-101 & Solid & Rotary & Hydrogen & SS, SW, HM \\
\hline C-106 & Solid & To be determined & High Heat & $\mathrm{R}, \mathrm{SS}, \mathrm{HM}$ \\
\hline AX-104 & Solid & $\begin{array}{l}\text { Light Duty } \\
\text { Utility Arm }\end{array}$ & None & $\mathrm{R}, \mathrm{SS}$ \\
\hline AW-101 & Supernatant & Grab & Hydrogen & $\mathrm{PV}, \mathrm{SP}$ \\
\hline AN-107 & Supernatant & Grab & None & PV, SP \\
\hline AZ-101 & Supernatant & Grab & None & $\mathrm{PV}, \mathrm{R}, \mathrm{SP}$ \\
\hline C-106 & Supernatant & Grab & High Heat & $\mathrm{PV}$ \\
\hline $\mathrm{AY}-102$ & Supernatant & Grab & None & PV, R \\
\hline B-103 & Vapor & Vapor & Organic & VS, VP \\
\hline $\mathrm{U}-112$ & Vapor & Vapor & None & VS, VP \\
\hline BX-104 & Vapor & Vapor & None & VS, VP \\
\hline BY-108 & Vapor & Vapor & Ferrocyanide & VS, VP \\
\hline C-107 & Vapor & Vapor & None & VS, VP \\
\hline S-102 & Vapor & Vapor & Hydrogen Organic & VS, VP \\
\hline TY-103 & Vapor & Vapor & Ferrocyanide & VS, VP \\
\hline
\end{tabular}

Notes:

FG = Flammable Gas

$\mathrm{HM}=$ Historical Model Evaluation

$\mathrm{OR}=$ Organic

PV = Privatization

$R=$ Retrieval

RGS $=$ Retained Gas Sampler

SS $\quad=$ Safety Screening

SP $=$ Supernatant Pretreatment

SW = Sludge Washing

VP $\quad$ Vapor Phenomenology

VS $=$ Vapor Screening 
longer within the scope of that issue. Because the retained gas sampler (RGS) cannot be used for tanks that require rotary-mode sampling, the above-named tanks can no longer provide useful information to the flammable gas program because they all require rotary-mode sampling. If the RGS sampler becomes available for rotary-mode sampling in the future, tanks 241-SX-104 and 241-BY-105 should be considered high priority tanks, because they contain waste types that are of interest to the flammable gas program. Sampling tanks 241-SX-104 and 241-BY-105 without the RGS sampler would be detrimental to the flammable gas program.

Another reason that tanks 241-TY-103, 241-BY-103, 241-BY-105, and 241-BY-106 are no longer high priority tanks is because they are on the ferrocyanide Watch List. Because sampling is no longer being performed for the ferrocyanide issue, the priority of these tanks has dropped even lower.

The high priority tanks, determined by applying the process outlined in this document, support the recommendations of the Defense Nuclear Facilities Safety Board (DOE-RL 1996). Tanks with known safety issues (Watch List tanks) are targeted for early resolution. The few non-Watch List tanks in Table ES-1 were selected to obtain information about poorly understood waste types and important waste phenomena. 


\section{CONTENTS}

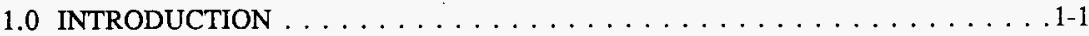

2.0 PROCESS FOR DETERMINING TANK PRIORITIES $\ldots \ldots \ldots \ldots \ldots \ldots$

3.0 ISSUES REQUIRING CHARACTERIZATION INFORMATION . . . . . . . . 3-1

3.1 ISSUES THAT AFFECT SAMPLING PRIORITY OF TANKS $\ldots \ldots \ldots$ 3-1

3.1 .1 Flammable Gas . . . . . . . . . . . . . . . . 3-1

3.1.2 Organic Fuel Phenomenology $\ldots \ldots \ldots \ldots \ldots \ldots \ldots \ldots$

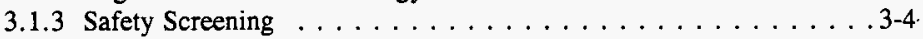

3.1 .4 Vapor Screening . . . . . . . . . . . . . . . . . .

3.1 .5 Vapor Space Phenomenology . . . . . . . . . . 3-6

3.1 .6 Ferrocyanide . . . . . . . . . . . . . . . . $3-6$

3.1 .7 Privatization . . . . . . . . . . . . . . . . 3-7

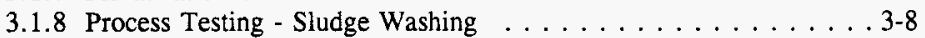

3.1.9 Process Testing - Supernatant Pretreatment . . . . . . . . . . 3-9

3.1 .10 Retrieval . . . . . . . . . . . . . . . . 3-11

3.1.11 Historical Model Evaluation . . . . . . . . . . . . 3-11

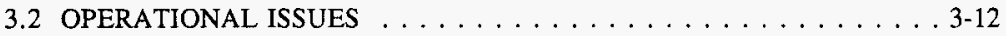

3.2.1 Compatibility of Waste Transfers $\ldots \ldots \ldots \ldots \ldots \ldots \ldots$ 3-12

3.2 .2 Caustic Mitigation . . . . . . . . . . . . 3-13

3.2.3 Evaporator Operations . . . . . . . . . . . . . . 3-14

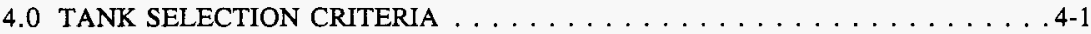

4.1 FLAMMABLE GAS CRITERIA . . . . . . . . . . . . 4-1

4.2 ORGANIC FUEL PHENOMENOLOGY CRITERIA . . . . . . . . . . 4-4

4.3 SAFETY SCREENING CRITERIA . . . . . . . . . . . . . 4-6

4.4 VAPOR SCREENING CRITERIA . . . . . . . . . . . . . 4-10

4.5 VAPOR SPACE PHENOMENOLOGY CRITERIA $\ldots \ldots \ldots \ldots \ldots$. . . . .

4.6 FERROCYANIDE CRITERIA . . . . . . . . . . . . . 4-12

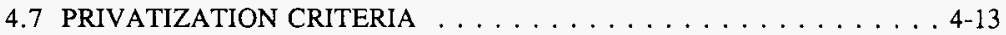

4.8 PROCESS TESTING - SLUDGE WASHING CRITERIA . . . . . . . 4-15

4.9 PROCESS TESTING - SUPERNATANT PRETREATMENT CRITERIA : 4-17

4.10 RETRIEVAL CRITERIA . . . . . . . . . . . . . . . . . . 4-19

4.11 HISTORICAL MODEL EVALUATION CRITERIA $\ldots \ldots \ldots \ldots$. . . 4-21

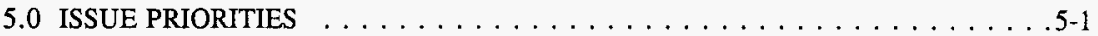

6.0 TANK PRIORITIES $\ldots \ldots \ldots \ldots \ldots \ldots \ldots \ldots . \ldots \ldots$. . . . . . . . . . . . . . .

6.1 TANK PRIORITY LIST FOR COMBINED ISSUES $\ldots \ldots \ldots \ldots \ldots$. . . . .

6.2 TECHNICAL CONSTRAINTS TO SAMPLING . . . . . . . . . 6-1

6.2.1 Number of Samples Previously Taken . . . . . . . . . . . . 6-9

6.2 .2 Number of Available Risers . . . . . . . . . . . . . . . 6-9 


\section{CONTENTS (Continued)}

6.2.3 Volume of Tank Waste . . . . . . . . . . . . . . . . . . . 6-9

6.3 TANK WASTE ANALYSIS PLAN REQUIREMENTS . . . . . . . . 6-9

7.0 SELECTION OF HIGH PRIORITY TANKS $\ldots \ldots \ldots \ldots \ldots \ldots \ldots \ldots .1$

7.1 APPROACH TO SELECT HIGH PRIORITY TANKS $\ldots \ldots \ldots \ldots \ldots 7-1$

7.2 HIGH PRIORITY TANKS FOR SOLID PHASE SAMPLING . . . . . . . 7-3

7.3 HIGH PRIORITY TANKS FOR LIQUID PHASE (GRAB) SAMPLING . 7-9

7.4 HIGH PRIORITY TANKS FOR VAPOR PHASE SAMPLING $\ldots \ldots \ldots$ 7-11

7.5 SUMMARY OF HIGH PRIORITY TANKS FOR SAMPLING $\ldots \ldots .7-12$

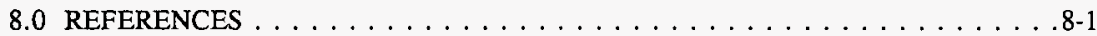

\section{APPENDICES}

A TANK PRIORITY MATRIX .................. A-1

B TANKS IN SCOPE OF ISSUES $\ldots \ldots \ldots \ldots \ldots \ldots \ldots \ldots$ B-

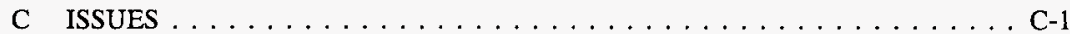

C1 FLAMMABLE GAS . . . . . . . . . . . . . . . . . C1-1

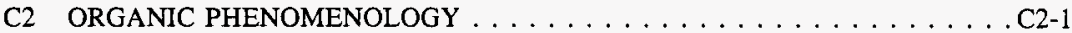

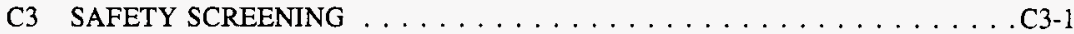

C4 VAPOR SCREENING . . . . . . . . . . . . . . C4-1

C5 VAPOR PHENOMENOLOGY $\ldots \ldots \ldots \ldots \ldots \ldots \ldots \ldots \ldots \ldots$ C5-1

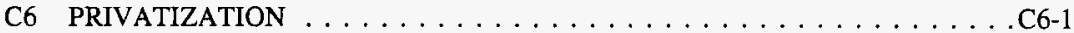

C7-1 PROCESS TESTING-SLUDGE WASHING $\ldots \ldots \ldots \ldots \ldots \ldots$ C7-1-1

C7-2 PROCESS TESTING - SUPERNATANT PRETREATMENT . . . . . . C C7-2-1

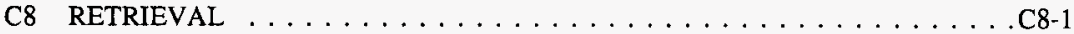

C9 HISTORICAL MODEL EVALUATIONS $\ldots \ldots \ldots \ldots \ldots \ldots \ldots \ldots$ C9-1

D INDIVIDUAL ISSUE PRIORITIES $\ldots \ldots \ldots \ldots \ldots \ldots \ldots \ldots \ldots \ldots \ldots$

E ISSUE PRIORITIES AND WEIGHTS $\ldots \ldots \ldots \ldots \ldots \ldots \ldots \ldots$ E-1

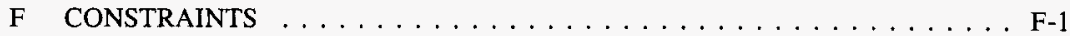


WHC-SD-WM-TA-164 Rev. 2

\section{LIST OF FIGURES}

2-1 Process of Determining High Priority Tanks for Sampling $\ldots \ldots \ldots \ldots$ 2-2

\section{LIST OF TABLES}

5-1 Results of the Multi-Attribute Utility Model Method of

Determining Relative Priority of Issues $\ldots \ldots \ldots \ldots \ldots \ldots \ldots \ldots$. . . . . . .

6-1 Tank Priority List With Technical Constraints . . . . . . . . . . . . 6-2

6-2 Tanks Available for Tank Waste Analysis Plan . . . . . . . . . . . . . 6-10

7-1 High Priority Tanks for Sampling $\ldots \ldots \ldots \ldots \ldots \ldots \ldots \ldots \ldots$ 7-13 


\section{LIST OF TERMS}

CC

DNFSB

DOE

DOE-RL

DQO

DSSF

DST

Ecology

EPA

HDW

HLW

LFL

LLW

NCAW

NCRW

NRC

RFP

RGS

SST

TCR

TOC

TRU

WHC

TWRS complexant concentrate

Defense Nuclear Facility Safety Board

U. S. Department of Energy

DOE Richland Operations Office

data quality objective

double-shell slurry feed

double-shell tank

Washington State Department of Ecology

U.S. Environmental Protection Agency

Hanford Defined Waste (model)

high-level waste

lower flammability limit

low-level waste

Neutralized Current Acid Waste

Neutralized Cladding Removal Waste

Nuclear Regulatory Commission

Request for Proposal for Privatization

retained gas sampler

single-shell tank

Tank Characterization Report

total organic carbon

transuranic

Westinghouse Hanford Company

Tank Waste Remediation System 


\subsection{INTRODUCTION}

Many safety concerns, coupled with high levels of uncertainty over tank contents, led the U.S. Department of Energy (DOE) to enter into an agreement to characterize the tank waste. This agreement, the Hanford Federal Facility Agreement and Consent Order (Tri-Party Agreement) (Ecology et al. 1996), was made between the DOE, the Washington State Department of Ecology (Ecology), and the U.S. Environmental Protection Agency (EPA). Another driver of tank characterization efforts is the DOE 93-5 Implementation Plan (DOE-RL 1996), which resolves Defense Nuclear Facility Safety Board (DNFSB) Recommendation 93-5.

This document establishes priorities for sampling and characterization activities conducted under the Tank Waste Remediation System (TWRS) Tank Waste Characterization Project. The Tank Waste Characterization Project is designed to provide all TWRS programs with information describing the physical, chemical, and radiological properties of the contents of 177 waste storage tanks at the Hanford Site. These tanks contain radioactive waste generated from the production of nuclear weapons materials at the Hanford Site. The waste composition varies from tank to tank because of the large number of chemical processes that were used when producing nuclear weapons materials and because the wastes were mixed during efforts to better use tank storage space. The Tank Waste Characterization Project mission is to provide information and waste sample material necessary for TWRS to define and maintain safe interim storage and to process waste fractions into stable forms for ultimate disposal.

The Tank Waste Characterization Basis (this document) integrates information needed to address safety issues, disposal projects, and historical model evaluation issues.

Characterization sampling to support tank farm operational needs is also discussed.

The document is outlined as follows:

- Section 2.0 outlines the process used to determine tank priorities.

- Section 3.0 describes the issues requiring information.

- Section 4.0 defines tank selection criteria.

- Section 5.0 defines the priorities of issues.

- Section 6.0 describes the process of setting tank priorities.

- Section 7.0 describes the high priority tanks recommended for sampling to best address issue needs.

The list of 28 high priority tanks determined in the previous revision of the Tank Waste Characterization Basis (Brown et al. 1995) is amended by the list of high priority tanks provided in Table 7-1 of this document. 
Six tanks (241-TY-103, 241-SX-104, 241-TX-111, 241-BY-105, 241-BY-103, and 241-BY-106), which were on the list of high priority tanks in Brown et al. (1995), are no longer on the list of high priority tanks. The primary reason is that they were to be sampled for the flammable gas issue; however, they are no longer within scope of that issue. Because the retained gas sampler (RGS) cannot be used for tanks that require rotary-mode sampling, the above-named tanks can no longer provide useful information to the flammable gas program because they all require rotary-mode sampling. If the RGS sampler becomes available for push-mode sampling in the future, tanks 241-SX-104 and 241-BY-105 should be considered high priority tanks because they contain waste types that are of interest to the flammable gas program. Sampling of tanks 241-SX-104 and 241-BY-105 without the RGS sampler would be detrimental to the flammable gas program.

Another reason that tanks 241-TY-103, 241-BY-103, 241-BY-105, and 241-BY-106 are no longer high priority tanks is because they are on the ferrocyanide Watch List. Because sampling is no longer being performed for the ferrocyanide issue, the priority of these tanks has dropped even lower.

The data quality objectives (DQO) process was used to develop the information needs of the various programs requiring information. Information needs (issues) integrated in this document are described in the following references:

- Flammable gas (McDuffie 1995 - DQO is currently being revised to incorporate single-shell tanks)

- Organic fuel phenomenology (Turner et al. 1995)

- Safety screening (Dukelow et al. 1995)

- Vapor screening (Osborne et al. 1995, Price 1994, Mulkey and Markillie 1995, and Laws 1996)

- Vapor space phenomenology (DOE-RL 1996)

- Ferrocyanide (Meacham et al. 1995b)

- Privatization (DQO currently in preparation)

- Process testing: sludge washing (Slankas et al. 1995 and Kupfer et al. 1995)

- Process testing: supernatant pretreatment (Slankas et al. 1995)

- Retrieval (Bloom et al. 1995)

- Historical model evaluation (Simpson and McCain 1996)

- Evaporator (Von Bargen 1995)

- Waste compatibility (Fowler 1995)

- Caustic Mitigation (test plans may be used where applicable). 


\subsection{PROCESS FOR DETERMINING TANK PRIORITIES}

The overall process used to determine the priority of tanks and to develop a list of high priority tanks for sampling is illustrated in Figure 2-1. The first steps of this process were performed by the TWRS programs requiring data. This led to the creation of an initial list of criteria for choosing tanks for sampling associated with each issue. On this document, 'criteria' refers to a standard set of tank characteristics or tank contents that are used to determine the priority of tanks for sampling.

To formalize and document the process of determining tank priorities, data and criteria used to choose tanks for sampling were entered into a computer spreadsheet. The mechanics of the computer spreadsheet (matrix) are described in Appendix A. A review of the process of setting tank priorities and the final selection of high priority tanks for sampling has been performed jointly by the Tank Waste Characterization Project, TWRS programs that require characterization information, and the DOE Richland Operations Office (DOE-RL). The outcome of this review is described in Section 7.0.

Throughout this document, tank priority refers to a number assigned to each tank that indicates the relative priority (or importance) of a tank with respect to the needs of the programs requiring characterization information. A 'high priority tank' is recommended for sampling; it is one that best integrates the needs of all the programs requiring characterization information.

The process of choosing tanks for sampling began with identifying issues specified by TWRS programs. For each issue, the criteria that make a tank more or less important were determined. Tanks were reviewed against these criteria, and the most important tanks associated with each issue were identified using the best available data.

The issues were weighted so that tanks required for addressing higher priority issues received more importance in the overall ranking than tanks required for less important issues. Determining the priorities of issues involved all TWRS programs requesting data and consensus from the DOE and Ecology. The tanks that have high priority for multiple issues were ranked higher overall because they provide the greatest information return for the sampling and analysis resource investment.

Once an initial priority list of tanks was generated, screening criteria were applied to remove applicable tanks from the priority list. Screening criteria were generated by the programs requesting data (based on need) and by the Tarik Waste Characterization Project. In this document screening criteria refers to technical constraints. The most common technical constraint used to screen tanks from sampling was whether a tank had already been sampled sufficiently to meet the needs of the TWRS programs requesting information. 


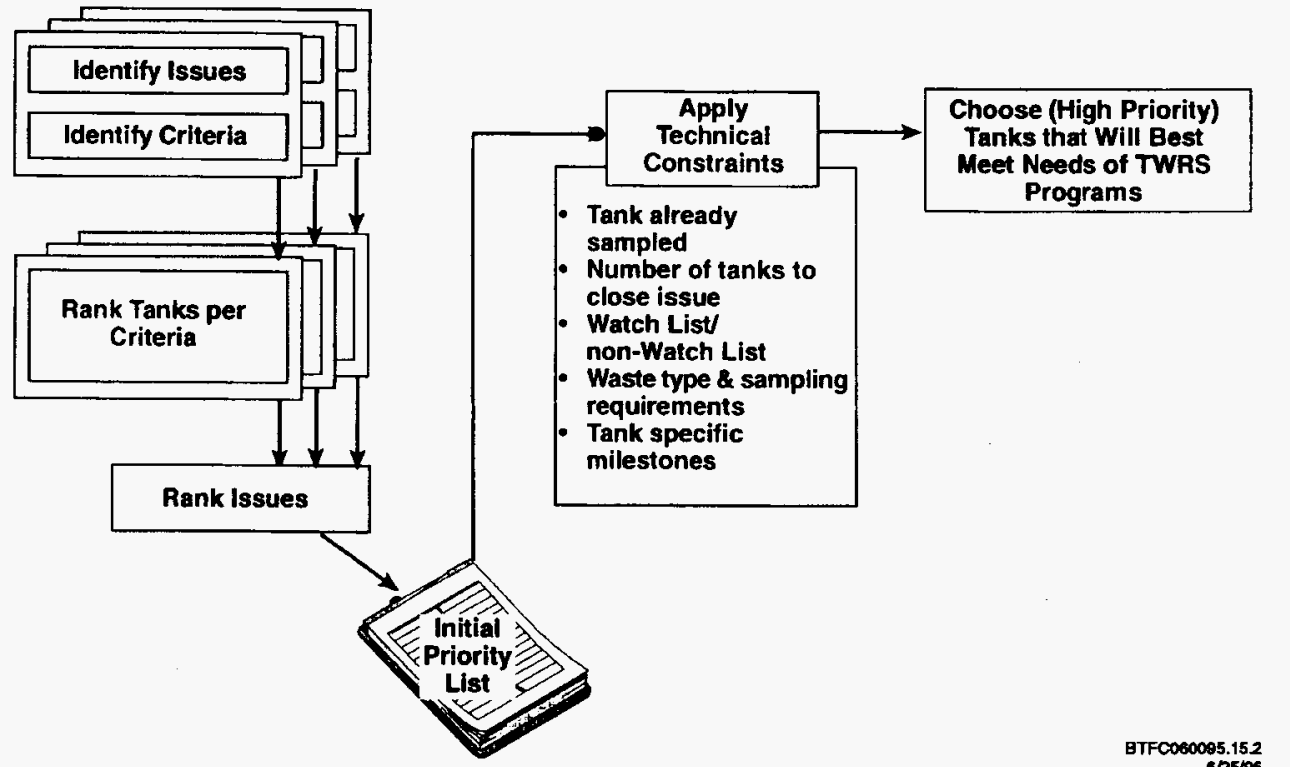

ETFC060095.152 
Operational constraints for the priority list of tanks are not within the scope of this document. Operational constraints will be considered when the sampling schedule is created.

The final product of the tank waste characterization basis is a current list of tanks (high priority tanks) recommended for sampling to obtain the maximum information about the waste in a cost-effective manner. The outcome of the process of determining high priority tanks for sampling is reviewed with the TWRS programs requesting data to ensure that their needs continue to be met. The list of high priority tanks will be updated often to best accommodate the changing needs of TWRS programs as additional information regarding tank issues is learned. 
WHC-SD-WM-TA-164 Rev. 2

This page intentionally left blank. 


\subsection{ISSUES REQUIRING CHARACTERIZATION INFORMATION}

Two general types of TWRS issues that require characterization information are discussed in this section.

1. Issues that affect the priority of tanks for sampling (safety, disposal, and historical model evaluation issues).

2. Operational issues.

Programmatic requirements (or information needs) for issues are developed through the DQO process (EPA 1994), which contain detailed information about characterization data requirements for each specific issue. The relevant DQOs are summarized in the following sections.

\subsection{ISSUES THAT AFFECT SAMPLING PRIORITY OF TANKS}

The three issues that affect the sampling priority of tanks are safety, disposal, and historical model evaluation. Safety issues include flammable gas, organic fuel phenomenology, safety screening, vapor screening, vapor space phenomenology, and ferrocyanide. Disposal issues include privatization, process testing for sludge washing and supernatant pretreatment, and retrieval.

To create an updated list of high priority tanks, criteria for tank selection must be developed. Before tank selection criteria can be determined, it is essential to understand the current status of each issue. For example, it is necessary to known (1) what information has been learned about the issue to date, (2) what the current decisions are that require characterization information for resolution, and (3) how sampling can provide necessary information to make decisions.

The process of determining high priority tanks for sampling is optimized by considering what has been learned already about the issue through tank characterization. Redundancies in characterization planning can be avoided by providing feed-back from the results of tank sampling.

\subsubsection{Flammable Gas}

3.1.1.1 Description of Issue. The possibility of releasing flammable gases into the vapor space of a waste tank is a major issue, because the ignition of confined gases could result in a release of radioactive and chemical materials to the environment. 
The issue of flammable gas release has been addressed by the Flammable Gas Tank Safety Program in Flammable Gas Tank Safety Program: Data Requirements for Core Sample Analysis Developed Through the Data Quality Objectives Process (McDuffie 1995).

3.1.1.2 Current Status of Issue. Some progress has been made to reduce gas retention. In tank 241-SY-101, gas retention was minimized using a large mixer pump to mix the waste. Dilution, heating, and sonic agitation of the waste may also reduce gas buildup and retention.

Although progress has been made in the flammable gas issue, many phenomena are still not understood. The flammable gas DQO states "insufficient knowledge has been obtained about the processes occurring within the waste that generate, retain, and release gases." To further explain and mitigate flammable gas retention, three approaches are used:

1. Measure gases released into the vapor space.

2. Monitor gas retention in the liquid and solid waste

3. Measure chemical and physical properties of the waste that could affect gas generation, retention, and release.

The first approach is implemented by measuring gas concentration and composition in the vapor space. Work for the first approach is ongoing, and data are being collected. Modeling and analysis of data to predict the degree to which a tank could develop a flammable gas problem is being performed. The two major references for predicting flammable gas producing tanks are, Methodology for Flammable Gas Evaluations, (Hopkins 1996) and Evaluation of Hanford Tanks for Trapped Gas, (Hodgson et al. 1996).

The second approach is implemented by monitoring the level of tank waste. Waste level measurements are used to estimate gas retention in tanks.

The third approach is implemented by measuring the chemical and physical properties of liquid and solid waste in flammable gas producing tanks. In particular, the chemical and physical properties of wastes, which are predicted to affect gas generation, retention, and release, are studied. Tank waste sampling and analysis is the primary method of determining the chemical and physical properties of the waste.

The motivation for the third approach is to develop a quantitative understanding of specific phenomena in the waste that tend to produce flammable gas. Understanding the phenomena of gas production, retention, and release will help to avoid flammable gas problems in the future and to identify options for remediating tanks that are known to have, or are suspected to have, a flammable gas problem. 
3.1.1.3 Basis for Tank Selection Criteria. Both single-shell tanks (SSTs) and double-shell tanks (DSTs) need to be studied for the flammable gas issue. When selecting tanks for the study, the criteria considered include tanks that are expected to produce high levels of flammable gas, tanks that represent different waste types, and tanks that are conducive to sampling using the RGS system. Criteria for selecting flammable gas tanks are specified in Section 4.1 .

\subsubsection{Organic Fuel Phenomenology}

3.1.2.1 Description of Issue. Organic complexant salts were sent to waste tanks. In sufficient concentrations with nitrates and/or nitrites and at sufficiently high temperatures, organic complexants could support a propagating chemical reaction. Organic complexant and solvent degradation products have been widely distributed in the tanks as a result of waste management activities (Agnew 1996a).

The DQO requirements for the organic complexant issue include energetics, moisture, total organic carbon (TOC) measurements, and at times, organic speciation (Turner et al. 1995).

3.1.2.2 Current Status of Issue. Several important conclusions about the organic fuel issue have been made. Recent work by G. S. Barney (1994 and 1995) has confirmed the solubility of fuel-rich organics in the waste aqueous phase. This suggests the fuel is associated with free-standing or entrained aqueous waste rather than precipitated with saltcake or sludge solids. However, it has been observed that saltcake waste, after interim stabilization, does not intrinsically retain sufficient moisture (greater than $20 \mathrm{wt} \%$ ) to completely rule out propagating chemical reactions in a tank (Atherton 1974, Handy 1975, Metz 1975, Kirk 1980, Epstein et al. 1994).

Recently, the Hanford Defined Waste (HDW) model (Agnew 1996a) was enhanced to include refined predictions of organics in the tanks. The HDW model predicts the contents of tanks using historical information, and it will be evaluated for its ability to accurately predict the organic contents of a tank.

Four key concerns are being evaluated for the organics issue: (1) to identify which tanks contain sufficiently high concentrations of fuel-rich organics to pose a risk for propagating reaction; (2) to determine whether organic complexants rapidly degrade to oxalate, formate, and carbonate, thereby posing no risk (Camioni 1994); (3) to determine whether organic complexants remain soluble in saturated salt media (Barney 1994) and, if so to determine whether they can be removed by saltwell pumping; and (4) whether wastes are resistant to drying out at tank ambient operating conditions.

3.1.2.3 Basis for Tank Selection Criteria. To respond to the concerns listed in Section 3.1.2.2, characterization is necessary. To provide information for the decision making on the organic fuel issue, it is desirable to select the tanks most likely to contain high quantities of organic material. Although some organic Watch List tanks are not believed to 
be a concern based upon the most recent studies of organic fuels, Watch List tanks still need to be considered. Finally, it is desirable to select some tanks that can be used to evaluate the efficacy of the HDW model. Criteria for selecting organic tanks are specified in Section 4.2.

\subsubsection{Safety Screening}

3.1.3.1 Description of Issue. The safety screening DQO (Dukelow et al. 1995) is applied to every tank to ensure the appropriate safety issues are identified. In response to the recommendations of the DNFSB (DOE-RL 1996), all tanks will be screened to determine the proper safety issue with respect to uncontrolled exothermic chemical reactions, the presence of flammable gases in the vapor space of the tank, and the potential for nuclear criticality. The DQO defines threshold concentrations of specific properties and analytes necessary to categorize the tank with respect to the appropriate safety issue.

3.1.3.2 Current Status of Issue. As of July 1, 1996, the sampling and analysis process was completed for 42 tanks to meet the requirements of the safety screening DQO. Nineteen of these tanks had no analysis exceeding the notification limits and had not been previously associated with any safety issue; therefore these tanks were categorized as safe: $241-\mathrm{A}-102$, 241-AN-106, 241-AP-108, 241-B-101, 241-B-112, 241-B-204, 241-BX-101, 241-BX-104, 241-BX-106, 241-BX-112, 241-C-107, 241-C-110, 241-C-203, 241-SX-113, 241-T-108, 241-TX-107, 241-TY-106, 241-U-201, and 241-U-202.

Ten tanks did not exceed the safety screening notification limits, but were previously associated with another safety issue; therefore, these tanks were not categorized as safe: 241-B-103, 241-C-108, 241-C-109, 241-C-111, 241-C-112, 241-S-102, 241-T-107, 241-TY-104, 241-U-203, and 241-U-204.

Thirteen tanks exhibited exothermic chemical reactions which exceeded the safety screening notification limits. Six tanks, which exhibited exothermic chemical reactions, had moisture concentrations above 20 percent, enough moisture to quench an exothermic reaction: 241-B-203, 241-C-204, 241-AN-102, 241-AN-107, 241-AX-102, and 241-T-111. Seven tanks, which exhibited exothermic chemical reactions, had moisture concentrations below 20 percent, potentially not enough moisture to quench an exothermic reaction: 241-BY-105, 241-BY-106, 241-BY-108, 241-C-103, 241-C-105, 241-C-201, and 241-C-202.

Six of the 13 tanks exhibiting exothermic chemical reactions are not currently associated with any other safety issues: 241-B-203, 241-C-201, 241-C-202, 241-C-204, 241-AN-102, and 241-AN-107. It is the objective of the safety screening DQO to ensure that tanks, which exceed notification limits but which are not currently associated with another issue, be assigned to a safety issue (for example, organic, flammable gas). The other seven tanks are presently associated with safety issues: 241-AX-102, 241-BY-105, 241-BY-106, 241-BY-108, 241-C-103, 241-C-105, and 241-T-111. 
The remaining tanks (other than the 38 tanks listed in this section) have not been sampled for safety screening or have been sampled for safety screening with incomplete results.

3.1.3.3 Basis for Tank Selection Criteria. Although all tanks are within the scope of safety screening, it is desirable to give sampling priority to tanks that are more likely to be unsafe. Tanks that are suspected of exhibiting exothermic reactions, emitting flammable gases, or having high concentrations of plutonium (according to historical based estimates of the tank contents), are a high priority for sampling. Other criteria used for selecting tanks for safety screening include suspected dry tanks (because of their inability to inhibit exothermic reactions) and tanks that contain waste types that are not well characterized. Criteria for selection of safety screening tanks are specified in Section 4.3.

\subsubsection{Vapor Screening}

3.1.4.1 Description of Issue. Characterization of the gases and vapors in the waste tank headspace is necessary to identify potentially hazardous waste storage conditions, support the worker health and safety assurance strategy, and to ensure regulatory compliance.

Information needs for all tanks must satisfy the Data Quality Objectives for Tank Hazardous Vapor Safety Screening (Osborne and Buckley 1995). Tanks to be rotary-mode sampled must also satisfy the Rotary Core Vapor Sampling Data Quality Objective (Price 1994) and the Data Quality Objective for Regulatory Requirements for Hazardous and Radioactive Air Emissions Sampling and Analysis (Mulkey and Markillie 1995) as amended by Status of the Current Understanding of the Toxic Air Pollutants (TAPS) and Hanford Tank Farm Vapor Space Characterization; Recommended Path Forward and Justification for Continued RMCS Exhauster Operations (Laws 1996).

3.1.4.2 Current Status of Issue. No tank headspace has levels of flammable gases or organic vapor at levels near the lower flammability limit (LFL). A summary of results from 43 tanks is provided in Headspace Gas and Vapor Characterization Summary for the 43 Vapor Program Suspect Tanks (Huckaby et al. 1995). To date, ammonia is the primary noxious gas of concern found in the tanks.

All 177 underground tanks must be vapor-sampled for organic solvent screening in accordance with the Recommendation 93-5 Implementation Plan (DOE-RL 1996). Some tanks may require additional vapor sampling because of other program needs. These tanks may be classified as (1) tanks that are to be rotary-mode core-sampled because of the rotary sampling system exhauster permit requirements, (2) tanks on organic or ferrocyanide Watch Lists, (3) tanks in C Farm because of large quantities of solvents that have been sent to $\mathrm{C}$ Farm, and (4) tank 241-BX-104 because of past vapor exposure. 
3.1.4.3 Basis for Tank Selection Criteria. The four categories of tanks above define the criteria for selecting tanks for vapor screening. Because vapor sampling has already been performed on the organic and ferrocyanide Watch List tanks, all tanks in C Farm, and on tank 241-BX-104, only tanks requiring rotary-mode sampling will be given higher priority. Criteria for selecting vapor screening tanks are specified in Section 4.4.

\subsubsection{Vapor Space Phenomenology}

3.1.5.1 Description of Issue. An understanding of headspace vapor phenomenology is essential to ensure that vapor samples are meaningful, and that results can be used, with confidence, to resolve vapor issues. The requirements for characterization of vapor samples to support the vapor space phenomenology issue are outlined in the Recommendation 93-5 Implementation Plan (DOE-RL 1996).

3.1.5.2 Current Status of Issue. Three concerns about headspace dynamics have been identified as critical to the technical basis of the vapor sampling effort. The first addresses whether samples, collected from a single tank headspace location, represent headspace in general (whether the vapor in the headspace is homogeneous). If large differences in composition exist from one location to another, samples at multiple locations would be required for vapor space characterization. The second addresses the extent to which vapor headspace composition changes with time. The third addresses how the exchange of atmospheric air and tank headspace vapor, or exchanges between overflow (cascade) connected tanks, affects the homogeneity and composition of the tank headspace vapor.

3.1.5.3 Basis for Tank Selection Criteria. Vapor characterization to support the issue of vapor phenomenology will be performed in three parts. (1) A spatial homogeneity study, planned for October, 1996, will examine whether large differences in vapor composition exist from one location to another in the tank headspace. (2) A current study is assessing the temporal changes (changes in time) of the tank headspace composition: samples from winter 1995 and spring 1996 have been collected; samples from summer, fall, and winter 1996 have yet to be obtained. (3) A study to measure the total ventilation rates of several passively ventilated tanks using a tracer gas is planned for Fiscal Year 1997. Criteria for selecting vapor space phenomenology tanks are specified in Section 4.5 .

\subsubsection{Ferrocyanide}

3.1.6.1 Description of Issue. To precipitate cesium, nickel sulfate and sodium ferrocyanide were added to 18 tanks to create sodium nickel ferrocyanide (Borsheim and Simpson 1991). Ferrocyanide, in sufficiently high concentrations and mixed with an oxidizing material such as sodium nitrate/nitrite, can be made to react exothermically by heating it to high temperatures (Epstein et al. 1994). Therefore, it is desirable to know whether a potential 
exists for an exothermic ferrocyanide reaction that could produce a radioactive release. Transfer records provided a strong justification that the ferrocyanide safety issue was limited to the ferrocyanide Watch List tanks (Borsheim and Simpson 1991).

3.1.6.2 Current Status of Issue. Originally, the ferrocyanide issue focused on the need to show that the ferrocyanide content in each tank could not sustain an exothermic reaction. This approach required core sampling of all ferrocyanide tanks to ensure that the fuel concentration was below $480 \mathrm{~J} / \mathrm{g}$ or that the moisture content was sufficient ( $\geq 20 \mathrm{wt} \%$ ) to prevent a propagating reaction.

Earlier laboratory work (Lilga et al. 1993 and 1994) and sampling results indicated that ferrocyanide degraded (aged) to nonreactive components during interim storage in the waste tank environment. A revised approach to ferrocyanide issue resolution (Meacham et al. 1995a and 1995b) focused on proving that the ferrocyanide had degraded. Nickel found in the waste indicates that sodium nickel ferrocyanide was present. If nickel is found in waste that exhibits no exotherms, then the ferrocyanide has degraded (Meacham et al. 1995b). Confirmation of this model was done by sampling only a few bounding ferrocyanide tanks. The need to sample all 18 tanks for ferrocyanide was eliminated. For selection of the bounding tanks to expedite closure of the ferrocyanide safety issue, refer to Brown et al. (1995).

Based on the conclusion that ferrocyanide has degraded to nonreactive components, the Westinghouse Hanford Company has requested the closeout of the ferrocyanide safety issue. The request was transmitted to DOE in July, 1996 (Bacon 1996).

3.1.6.3 Basis for Tank Selection Criteria. For the purposes of determining tank priorities, it is assumed that the current recommendation to close out the ferrocyanide safety issue will be accepted by the DOE; therefore, there is no need to define criteria for selecting ferrocyanide tanks.

\subsubsection{Privatization}

3.1.7.1 Description of Issue. The treatment and disposal of tank waste is contracted to private companies under a DOE initiative referred to as "privatization." Gathering information on the composition of waste in specific tanks is a high priority so that the contractors can develop and construct the proper process for waste treatment and the management and integrating contractor can select, stage, and provide waste to the private contractor.

Characterization requirements to support the privatization effort will be outlined in the privatization DQO which is currently being prepared. 
3.1.7.2 Current Status of Issue. The first phase of privatization is to demonstrate that waste supernatant material can be pretreated to form low-level waste (LLW) products. Immobilization of washed sludge into a high-level waste (HLW) product is an option of the first phase.

3.1.7.3 Basis for Tank Selection Criteria. Under privatization, a number of tanks have been selected for demonstrating the first phase. The primary criterion for determining tanks to sample for privatization is to give the highest priority to the tanks from which samples will be taken for the contractors. A second criterion for sampling the first phase tanks places the tanks in the order in which they are expected to be staged to the contractor for processing. The final criterion places tanks in order by the date after which no more transfers in or out of the tanks are expected. Criteria for selecting privatization tanks are specified in Section 4.7.

\subsubsection{Process Testing - Sludge Washing}

3.1.8.1 Description of Issue. Tank wastes will be pretreated to separate them into HLW and LLW streams. The HLW stream will contain the bulk of the radionuclides. The LLW stream will contain the bulk of the chemical waste in the tanks, a much larger volume. Sampling can be broken down into two categories: (1) sampling and analysis of tank solids and supernatant to evaluate sludge washing behavior; and (2) supernatant sampling to evaluate liquid pretreatment technologies (especially cesium removal). Characterization to evaluate sludge washing behavior is considered in this section. Characterization to evaluate liquid pretreatment technologies is considered in Section 3.1.9.

The baseline sludge pretreatment steps are water washing and caustic leaching. Water washing will dissolve soluble species from insoluble sludge. Leaching is expected to dissolve significant portions of chromium, aluminum, and phosphate in certain tank sludges. The wash solutions will be decanted to separate them from the HLW solids. The fundamental characterization need for sludge washing is to obtain samples from as many different waste types as possible (Kupfer et al. 1995 and Slankas et al. 1995). Characterization support for sludge washing issues will consist of providing samples to the programs performing sludge washing.

3.1.8.2 Current Status of Issue. To date, a number of tank samples have been evaluated for sludge washing characteristics (Lumetta and Rapko 1994, Rapko et al. 1995, Temer and Villarreal 1995a and 1995b). Additional tank samples will be required for sludge washing, as addressed in Strategy for Sampling Hanford Site Tank Wastes for Development of Disposal Technology (Kupfer et al. 1995).

Sludge washing efficiency, solid/liquid separations efficiency, and time required for pretreatment functions will be addressed through full =scale testing in tank 241-AZ-101. Sampling will be required at various times during the test to evaluate performance. 
3.1.8.3 Basis for Tank Selection Criteria. The most important consideration is to ensure the majority of the waste in tank farms is represented by sampling; therefore tanks should be selected that represent waste types which are not well-characterized. The least understood waste type is REDOX waste, followed by non-bismuth phosphate sludge waste types and saltcake waste types. Because aluminum and chromium have a significant affect on the total volume of HLW glass produced in vitrification disposal processes, tanks estimated to have high aluminum and chromium contents also are given high priority. Wastes, which have been subjected to high temperatures for long periods of time (self-boiling wastes), are expected to exhibit significantly different chemical properties than wastes stored at lower temperatures. For this reason, former self-boiling tanks in the $S$ and SX Farms have priority. Tanks with high-waste volumes (preferably sludge) are preferred to tanks with low waste volume, because insoluble sludge wastes greatly affect the amount of HLW glass produced. Finally, priority is given to tank 241-AZ-101 because of the retrieval and sludge washing demonstration. Criteria for selecting tanks for sludge washing are specified in Section 4.8 .

\subsubsection{Process Testing - Supernatant Pretreatment}

3.1.9.1 Description of Issue. The baseline supernatant liquid pretreatment process is to remove cesium from the waste. Cesium removal is necessary to (1) bring Neutralized Current Acid Waste (NCAW) supernatant within U.S. Nuclear Regulatory Commission (NRC) Class C limits, and (2) meet NRC incidental waste criteria.

The NRC regulates the disposal of HLW. Supernatant waste is currently classified as HLW. If the waste is left in its current state, it will require NRC regulation and repository disposal. By pretreating the supernatant to the greatest extent practical economically and technically, the waste can be reclassified as "incidental" or low activity waste, suitable for disposal onsite (provided all onsite disposal requirements are met).

Two cesium removal technologies will be evaluated: ion exchange with resorcinol/ formaldehyde resin and sorption within a crystalline silicotitanate matrix. Alternate liquid pretreatment technologies, which may be evaluated, include removing technetium, strontium, and transuranic (TRU) elements. Removing technetium may be desirable to improve the projected performance of the LLW disposal system. Removing strontium may be desirable to decrease doses incurred during operational activities. Removing transuranic (TRU) elements will be necessary to meet NRC Class $\mathrm{C}$ waste criteria for a limited number of tanks.

Characterization support for supernatant pretreatment will consist of providing samples to the programs performing pretreatment. Laboratory analysis of samples is not required (Slankas et al. 1995). 
3.1.9.2 Current Status of Issue. Testing with hot tank samples is expected to continue in 1996. Three major liquid waste types will be tested: (1) noncomplexed double-shell slurry feed (DSSF), (2) complexant concentrate (CC), and (3) NCAW. Testing in Fiscal Year 1996 will include only DSSF waste from tank 241-AW-101.

3.1.9.3 Basis for Tank Selection Criteria. To evaluate liquid waste pretreatment technologies, samples of several major DST waste types (DSSF, CC, and NCAW) are required; therefore, tanks predicted to have high quantities of DSSF, CC, and NCAW wastes are a high priority. In the future, Neutralized Cladding Removal Waste (NCRW) may be studied. Tanks predicted to have NCRW waste are a low priority for liquid pretreatment. Criteria for selecting tanks for supernatant pretreatment are specified in Section 4.9.

\subsubsection{Retrieval}

3.1.10.1 Description of Issue. In the Tri-Party Agreement, the DOE made a commitment to retrieve all tank wastes before pretreatment and disposal. Single-shell tank wastes will be mobilized by sluicing, then transferred by a slurry pump (these technologies have been successfully demonstrated previously at the Hanford Site). Double-shell tank sludges will be mobilized by mixer pumps, then transferred by slurry pump.

The DQO for the retrieval program (Bloom and Nguyen 1995) identifies the sampling of tank 241-AZ-101 as high priority. Most data needs are currently being met through evaluation of historical data and sampling conducted for other programs. However, future needs, including in-situ measurements and ex-situ analysis of tank samples in support of specific retrieval activities, will need to be integrated into characterization planning as early as September 1996. Specific tank sample analysis required for future retrieval needs are discussed below and will be considered when determining tank priorities.

3.1.10.2 Current Status of Issue. A full-scale, in-tank mixer pump and sludge washing demonstration is planned for tank 241-AZ-101 in November 1996. This demonstration will help verify the sludge mobilization model used for predicting mixer pump performance and confirm the mixer pump concept for retrieving DST sludges. In addition, data critical to retrieval and sludge pretreatment will be obtained, for example, solids settling rate, sludge washing efficiency, and impact of retrieval activities on in-tank equipment.

Retrieval activities are scheduled to begin by transferring sludge from tank 241-C-106 to 241-AY-102 in 1998. Retrieval will be accomplished by sluicing. Retrieval of tank 241-C-106 waste will resolve the high heat issue for tank 241-C-106 (the only tank on the high heat Watch List).

Future plans may call for retrieval and transfer of sludge in tank 241-SY-102 into 241AW-103 via mixer pump mobilization. Transfer of sludge from tank 241-SY-102 will consolidate TRU sludges and free up critical DST space in the 200 West Area (Powell et al. 1996). 
Subsequent SST retrieval activities are expected to focus on the A and AX Farms.

The following questions require characterization data to plan SST retrieval projects. (1) Are predicated emission or gases released during retrieval activities within the design envelopes. Emissions include toxic (for example, ammonia), radiological emissions, and organic vapors. (2) Will retrieval operations, the radiological inventory and the Hazardous Material Inventory be within the operating parameters outlined in the safety documentation. (3) Will the retrieved waste be compatible with waste in the receiving tank. (4) Could retrieval operations develop a concentration of plutonium in the waste that would lead to nuclear criticality concerns.

3.1.10.3 Basis for Tank Selection Criteria. Retrieval characterization needs have a high impact on schedules for retrieval projects and tank waste retrieval operations. Sampling needs are determined from retrieval project design dates and waste retrieval operations schedules. Criteria for selecting tanks for retrieval needs are specified in Section 4.10.

\subsubsection{Historical Model Evaluation}

3.1.11.1 Description of Issue. The HDW model, developed by the Los Alamos National Laboratory, uses historical information to predict the contents of waste tanks (Agnew 1996b). The HDW model uses information about waste transfer logs, chemical purchase records, and process flow sheets to estimate the inventory of certain analytes in the tank. Currently, the HDW model is not used in decision-making, because the data quality used in the model and the assumptions driving the model have not been fully validated. Few historical composition estimates are available that have analytical data or error estimates associated with waste composition. At the same time, it is extremely difficult to interpret or use contemporary data that cannot be placed in a historical context. If the model estimates have not been rigorously examined, and the uncertainties have not been quantified, the estimates are of limited use. The implications of making an incorrect or inappropriate decision based on historical data must be weighed by users.

The purpose of the historical model evaluation DQO (Simpson and McCain 1995) is to evaluate the ability of the HDW model to accurately predict tank waste composition.

3.1.11.2 Current Status of Issue. Several tanks of interest have been sampled to evaluate the HDW model. Observations have been made regarding the assumptions used in the historical model, particularly with respect to source terms, waste distribution, and analyte solubility. Systematic biases, parameter sensitivities, and some computational discrepancies in the HDW model have been revealed.

The following have been questions asked for the historical model evaluation. (1) How well do data from segment samples correlate with the HDW model to predict the expected position/configuration of a waste type within a tank and in defining/quantifying specific waste 
types. (2) How well do the data from a sampling-based inventory estimate of a tank correlate with the inventory derived from the HDW model.

3.1.11.3 Basis for Tank Selection Criteria. Characterization information is necessary to provide estimates of uncertainty that will determine the appropriate uses of the HDW model. To provide information for this evaluation, tanks were selected from a variety of categories and configurations. The tanks selected fall into three categories: spatially complex tanks that received several types of waste; tanks rich in REDOX, PUREX, saltcake, and uranium recovery waste types; and tanks that have multiple risers available in different lateral configurations.

Criteria for selecting tanks to sample for the historical model evaluation are based on these three categories. The criteria are specified in Section 4.11.

\subsection{OPERATIONAL ISSUES}

Tank farm operations requires characterization sampling for the compatibility of waste transfers, caustic mitigation, and the evaporator. These operations are discussed in this section.

Operational issues do not affect sampling priority of tanks for this document; however, they are important. Operational needs are not integrated into the tank priority in this document because they cannot usually be effectively foreseen in advance. Operational needs for characterization sampling are driven by day-to-day operations schedules. Operations schedules are dynamic and change too often to be incorporated effectively into an integrating document. When the need arises to sample a tank for operations, the need will be incorporated into the sampling schedule after assessing the impact of sampling high priority tanks.

\subsubsection{Compatibility of Waste Transfers}

Characterization sampling to support waste compatibility issues and waste transfer is performed before transferring waste in accordance with the Data Quality Objectives for Tank Farms Waste Compatibility Program (Fowler 1995). Waste transfers that require sampling for the compatibility DQO are DST to DST, SST to DST, and waste generating processes to DSTs.

All DSTs are within the scope of the compatibility DQO. The SSTs are within the scope of the compatibility DQO only if waste is scheduled to be transferred out of an SST, for example, for tank stabilization.

The compatibility DQO has two functions. The first is to ensure that DSTs comply with existing requirements and guidelines including operating specification document limits, 
operational safety requirements, and criticality prevention specifications. The guidelines are based on chemical or physical measurements of the waste. The second is to ensure that the potential for release of HLW is not increased by performing the transfer (particularly with transfers involving Watch List tanks or tanks having other unsafe conditions).

When waste is scheduled to be transferred to a DST, both the receiver and the source tanks (SST, DST, or process tank) will be sampled according to the compatibility DQO. An exception to this is the transfer of waste from a candidate feed tank (to be evaporated) to evaporator feed tank 241-AW-102. Such transfers are governed by the evaporator DQO (see Section 3.2.3).

Before sampling is performed for the compatibility DQO, the affect of the sampling effort on the sampling of any high priority tank will be evaluated.

\subsubsection{Caustic Mitigation}

Some DSTs have predicted corrosion rates that are not within the operating specifications determined by the compatibility DQO. These tanks are referred to as "caustic deficient." Operations often require characterization sampling and analysis of such tanks to properly mitigate caustic deficiency. Currently, no DQO exists to direct the sampling and analysis of caustic deficient tanks. When sampling and analysis of caustic deficient tanks is required, operations must provide a request for sampling analysis or a process memo to direct characterization work.

Only DSTs are required to remain within the operating specifications outlined in the compatibility DQO. The DSTs, which are not currently within the operating specifications and are labeled as caustic deficient, are tanks 241-AN-107, 241-AN-102, 241-AY-101, and 241-AZ-101. In addition, although tank 241-AY-102 is currently within operating specification, it is expected to become caustic deficient near the end of Fiscal Year 1996.

Sampling and analysis of caustic deficient tanks is performed to determine the predicted corrosion rate of the tank. Characterization information obtained for caustic deficient tanks is evaluated to determine whether caustic additions to the tank will bring the tank back within specification or whether some other type of mitigation effort is necessary.

The sampling and analysis of caustic deficient tanks is schedule-driven. When a DST falls out of operating limits, operations schedules will determine whether characterization sampling and analysis is required.

Before sampling for caustic mitigation is performed, the effect of the sampling effort on the sampling of any high priority tank will be evaluated. 


\subsubsection{Evaporator Operations}

Successful operation of the 242-A Evaporator requires sampling and analysis of the evaporator feed waste. Sampling and analysis is directed by 242-A Evaporator/Liquid Effluent Retention Facility Data Quality Objectives (Von Bargen 1995).

Several tanks are associated with evaporator operations. Tank $241-\mathrm{AW}-102$ is the feed tank to the evaporator. Tank 241-AW-106 receives the evaporator bottoms after waste evaporation, it is called the slurry tank. Tanks 241-AW-102 and 241-AW-106 are not sampled in accordance with the evaporator DQO for normal evaporator operations because both tanks were sampled before the evaporator campaigns started. Evaporator condensate is sent to the Liquid Effluent Retention Facility. Tanks that transfer waste to the feed tank for processing in the evaporator are called candidate feed tanks. Candidate feed tanks include tanks 241-AP-103, 241-AP-104, 241-AP-105, 241-AP-106, 241-AP-107, and 241-AP-108. Candidate feed tanks are the only tanks that will be sampled in accordance with the evaporator DQO.

The evaporator DQO has three functions. Process control evaluation ensures the evaporator operates efficiently with minimal equipment depreciation. Process control evaluation also compares the waste compatibility in the candidate feed tanks with the wastes in the feed and slurry tanks. Safety evaluation ensures that hazardous wastes do not endanger workers or the environment. Environmental compliance evaluation ensures the waste released to the slurry tank, the gases released to the air, and the water released to Liquid Effluent Retention Facility are in compliance with environmental limits.

Sampling to support evaporator operations will be performed on candidate feed tanks involved in upcoming evaporator campaigns. Since the evaporator DQO includes waste compatibility and safety functions within its scope, the compatibility DQO will not be applied to candidate feed tanks. The characterization sampling of candidate feed tanks will be driven by operations schedules.

Before sampling for the evaporator DQO is performed, the effect of the sampling effort on the sampling of any high priority tank will be evaluated. 


\subsection{TANK SELECTION CRITERIA}

This section provides a detailed description of the criteria used for tank selection. Tank selection criteria refers to a standard set of characteristics of the tanks or tank contents important to TWRS programs. The criteria are used to determine the priority of tanks for sampling.

This section discusses only issues that have an influence on the priority ranking of tanks for sampling. It does not discuss operational issues.

The following information is addressed for each issue:

- The tanks within the scope of each issue. If the list of tanks within the scope of an issue is too large, a reference may be provided.

- The tank selection criteria for each issue as determined from the basis provided in Section 3.1

The following information is provide for each individual criterion:

- The relative priority of each criterion (high, medium, or low).

- The source of data that will be used to determine the priority of each tank with regard to the criterion, within the scope of the issue (including a description of the data source).

- The tank ranking (high, medium or low priority) for each criterion.

This section results in a priority list of tanks for each individual issue. The priority lists are generated using the tank selection criteria. A spreadsheet matrix is used to determine the priority order of all tanks within the scope of each issue. The spreadsheet matrix is described in Appendix A. A printout of the matrix for each issue is provided in Appendices C1 through C9. The overall priority list of tanks from combined issues is discussed in Sections 6.0 and 7.0 .

\subsection{FLAMMABLE GAS CRITERIA}

The criteria for determining which tanks are within the scope of the flammable gas issue are outlined in the Criteria for Flammable Gas Watch List Tanks (Hopkins 1994). In the Evaluation of Hanford Tanks for Trapped Gas (Hodgson et al. 1996), tanks are compared against the criteria outlined in Hopkins. Tanks meeting the criteria outlined for flammable gas Watch List tanks are within the scope of the flammable gas issue. Currently, 57 tanks (double-shell and single-shell) are suspected of producing unsafe amounts of flammable gas. 
A subset of the 57 tanks are within the scope of the flammable gas DQO for sampling and within the scope of the flammable gas issue for this document.

Until recently, only DSTs were sampled for the flammable gas issue. The DSTs are the most important tanks for the flammable gas issue because of their episodic releases of flammable gases. Sampling DSTs that experience episodic gas releases but have not yet been sampled remains the highest priority. After flammable gas DSTs have been sampled, high priority flammable gas SSTs will be sampled. The most important criteria for determining priority for sampling flammable gas SSTs is the ability of the tank waste to retain gases. Of secondary importance, is the need to represent different types of waste. Finally, since the RGS cannot be used during rotary-mode core drilling, SSTs must be soft enough to push-mode sample.

Requirements for flammable gas DSTs are outlined in McDuffie (1995). Requirements for SSTs will be outlined in the revision of the flammable gas DQO now being prepared. SSTs sampled before the new DQO is issued will require a letter of instruction (or test plan) to document interim requirements. Single-shell tanks within the scope of the flammable gas issue are outlined in Cash (1996a).

\section{Criterion 1: Episodic Gas Release}

Priority: High

Data Source: $\quad$ Some DSTs experience episodic releases of flammable gas. These are the Watch List DSTs reported in the Waste Tank Summary Report for Month Ending February 29, 1996 (Hanlon 1996).

Tank Ranking: High priority is assigned to all tanks that exhibit episodic gas releases. Low priority is assigned to all other tanks.

\section{Criterion 2: Gas Retention}

Priority: High

Data Source: Gas retention is documented in Hodgson et al. (1996) which evaluated all 177 tanks for trapped flammable gas using the flammable gas criteria in Hopkins (1994). Flammable gas concentrations are given as percent of the LFL and are estimated from the steady state concentration in the tank headspace and the volume of the trapped gas using the methodology given in Hopkins (1996). Steady state values for \%LFL were calculated from hydrogen and ammonia concentrations in the vapor space samples (if recently sampled) or by using a method discussed in Hopkins (1996). The volume of the trapped gas was calculated 
Hopkins (1996). The volume of the trapped gas was calculated based on surface level rise and the barometric pressure/surface level correlation.

Tank Ranking: $\quad$ Priority was assigned to each tank based upon Hodgson (1996). The greater \%LFL [(steady state LFL + surface level rise LFL)] or [(steady state LFL + barometric pressure LFL)] was used to assign the priority.

High: \%LFL $\geq 200$

Medium: \%LFL between 200 and 100

Low: \%LFL $\leq 100$

\section{Criterion 3: Waste Type}

Priority:

Data Source:

Tank Ranking:

\section{Medium}

Waste types recognized as potentially having different properties with respect to the flammable gas issue are documented in the Prioritization of Single Shell Tanks for Study of Gas Retention and Episodic Release (Brewster and Palmer 1995) and the Analysis of Visual Waste Observations for Single-Shell Tanks (Recknagle 1996). Tanks were categorized into four waste configurations (Recknagle 1996). Configuration 1 contains a mixture of saltcake and salt slurry, configuration 2 contains primarily saltcake, configuration 3 contains sludge and saltcake, and configuration 4 contains primarily sludge.

High: The tank with the highest LFL from each of configurations 1,2 , and 3 .

Medium: All other tanks in configurations 1, 2, and 3.

Low: All tanks in configuration 4 and tanks not assigned to any waste configuration. Sludge tanks were considered to be of low priority with respect to the flammable gas issue. 
Criterion 4: Ability to be Sampled by RGS

Priority: High

Data Source: $\quad$ Currently, the RGS sampler can be used only in push-mode sampling. Tanks that can be push-mode sampled are documented in the Baseline Sampling Schedule, Change 96-02 (Stanton 1996).

Tank Ranking: $\quad$ High: Tanks that can be push-mode sampled.

Low: All other tanks.

\subsection{ORGANIC FUEL PHENOMENOLOGY CRITERIA}

Thirty six tanks are within the scope of the organic safety issue, as listed in Turner et al. (1995). Some tanks were originally on the organic Watch List (WHC 1994), and some tanks have been identified recently as a potential safety concern in the Preliminary Safery Criteria for Organic Watch List Tanks at the Hanford Site (Webb et al. 1995) Five tanks in Turner et al. are included in the scope: tanks 241-AX-101, 241-C-104, 241-C-107, 241-C-202 and 241-SX-103. These tanks will be used to evaluate the HDW model as reported in History of Organic Carbon in Hanford HLW Tanks: HDW Model Revision 3 (Agnew 1996a). Tanks added to the scope of the organic DQO are documented in Cash (1996b) and Cash (1996c).

The first two criteria listed below determine which Hanford Site tanks have the potential to become unsafe with respect to the amount of organic fuel and water expected to be in the tanks. The third criterion is to support continued sampling of tanks on the organic Watch List. The final criterion for determining the priority of organic tanks for sampling is the evaluation of the HDW model as reported in Agnew (1996a) report for organic tanks.

\section{Criterion 1: Tanks that Become Potentially Unsafe If Pumped of Liquids}

Priority: High

Data Source: The primary source of information used to determine the priority of organic tanks is Webb et al. (1995), which evaluates the organic carbon in tanks using current core sample data and older processing data of percent TOC and percent water in the tanks. The Sort on Radioactive Waste Type Model: A Method to Sort Single-Shell Tanks into Characteristic Groupings

(Hill et al. 1995) is used to predict the TOC and water contents of tanks where data is not available for a particular tank. The 
model data is used to determine whether any tanks are unsafe or have the potential to become unsafe if moisture is pumped from the tank or drying occurs.

Tank Ranking: High priority is assigned to all tanks that will be potentially unsafe if drained of their liquids: tanks 241-A-102, 241-BX-110, 241-BY-102, 241-TY-102, 241-U-102, 241-U-103, 241-U-105, 241-U-107, 241-U-108, and 241-U-109. All other tanks are assigned low priority.

\section{Criterion 2: Tanks that Become Potentially Unsafe If Pumped and Dried for 50 Years}

Priority: $\quad$ Medium

Data Source: $\quad$ Some tanks may fall into the unsafe category if they are pumped and then allowed to dry for 50 years. Tanks that become potentially unsafe if pumped and dried for 50 years are evaluated in Webb et al. (1995). The list of tanks includes all tanks listed in criterion 1 plus tanks 241-B-102, 241-BX-105, and 241-BY-108.

Tank Ranking: High priority is assigned to all tanks that meet this criterion. All other tanks are assigned low priority.

\section{Criterion 3: Current Organic Watch List}

Priority: Low

Data Source: $\quad$ The data source for organic Watch List tanks is the Operating Specifications for Watch List Tanks (WHC 1994).

Tank Ranking: High priority was assigned to all organic Watch List tanks. Low priority was assigned to the remaining tanks within the scope of the organic issue.

\section{Criterion 4: Evaluation of Hanford Defined Waste Model for Organic Tanks}

Priority: High

Data Source: $\quad$ The History of Organic Carbon in Hanford HLW Tanks: HDW Model Revision 3 (Agnew 1996a) was used to select tanks that are predicted by the HDW model to contain high quantities of organic carbon. The selected tanks were predicted to have high organic carbon by the HDW model, but not by Webb et al.

(1995). Selecting tanks on which the models disagree provides a 
basis for evaluating the efficacy of both models. The tanks were selected from three categories in Agnew (1996a):

1. Organics in sludges: tanks 241-C-104 and 241-AX-101

2. Surface residual organics: tanks $241-\mathrm{C}-107$ and 241-C-202. (Tank 241-C-107 has already been sampled)

3. Organics in concentrates: tanks 241-SX-103 and 241-AX-101

When evaluating the HDW model, it is desirable also to select tanks for sampling that the two models do agree upon. Tanks that both models predict to have high organics should not be given additional priority under this criterion because they already receive high priority under criterion 1. Tanks that both models predict to have high organic content, however, should be given consideration when selecting the recommended high priority tanks (see Section 7.0). Both models estimate that the following tanks to have high organic:

1. Organics in sludges: tank 241-A-102

2. Surface residual organics: tank 241-BY-102

3. Organics in concentrates: tank 241-U-109

Tank Ranking: Tanks that are predicted to have high amounts of organic carbon by Agnew (1996a) but not by Webb (1996) are given high priority: tanks 241-AX-101, 241-C-104, 241-C-107, 241-C-202, 241-C-103, and 241-SX-103. All other tanks are given low priority.

\subsection{SAFETY SCREENING CRITERIA}

All SSTs and DSTs fall within the scope of the safety screening issue. The criteria used for determining tank priority within the safety screening issue relate to wastes exhibiting exothermic reactions (energetics), plutonium content, waste types that are not well characterized, waste dryness, and flammable gases.

Criterion 1: Energetics

Priority: High

Data Source: The criterion used to determine the priority of tanks for energetics is based upon expected TOC in the tanks. The exothermic energy expected to be measured in tank waste is not derived by the TOC concentration in the tank waste; TOC is 
Tank Ranking: $\quad$ Priority was assigned to each tank based upon the predicted TOC in the tank from Agnew (1996a).

High: TOC $\geq 1$ wt $\%$

Medium: TOC between $0.4 \mathrm{wt} \%$ and $1 \mathrm{wt} \%$

Low: TOC $\leq 0.4 w t \%$

\section{Criterion 2; Plutonium (Criticality)}

Priority: Medium

Data Source: $\quad$ Several sources of data are considered when priority with respect to criticality is determined. Initially, tanks are assessed to determine whether they contain any sludge or only supernatant and/or saltcake. Fissile materials are expected to remain in the insoluble sludge fraction. The tank layer model, a component of the HDW model reported in the Hanford Tank Chemical and Radionuclide Inventories: HDW Model, (Agnew 1996b), is used to perform this assessment. This model predicts which tanks were used to store evaporator bottoms (saltcake) and/or sludge. The tank layer model was developed from the transfer histories of the waste tanks from the first use of the tanks until the present. The following tanks are of particular interest to the Criticality Safety Program: 
tanks 241-BY-106, 241-C-102, 241-C-104, 241-C-106, 241-S-107, 241-TX-118, 241-SY-102. Specific details are provided in the following sources:

241-C-104, 241-C-106, Estimated as having a high

241-C-102, 241-S-107: plutonium content in the HDW report (Agnew 1996b)

241-BY-106, 241-TX-118: Passive neutron scans indicate potential high plutonium content (Toffer 1994)

241-SY-102:

High plutonium content (Tusler 1995)

Tank Ranking

The criticality safety issue encompasses all tanks. Tanks are assigned as low, medium, or high priority based on the following:

Low: All tanks predicted to contain 95 percent by volume of supernate or saltcake (tank layering model).

High: All tanks predicted to contain 95 percent by volume of first/second cycle sludge, uranium recovery sludge, metal waste sludge, or REDOX waste sludge. The seven tanks mentioned above are also high priority.

Medium: All tanks not ranked high or low are assigned medium priority.

\section{Criterion 3: Non-Characterized Waste Types}

Priority:

Data Source:

Tank Ranking

\section{Medium.}

The intent of this criterion is to sample tanks whose waste types are not well understood; therefore, the tank layering model was used (Agnew 1996b) because it can be used to target the tanks that contain waste types that have not yet been well sampled.

Using the tank layering model, tanks were grouped and assigned a category based on the major type of waste predicted to be in the tank. A priority of high, medium, or low was assigned to each tank based on how well that waste type has been sampled already. 
High: Less than $25 \%$ of the tanks in the category have already been sampled.

Medium: Between $25 \%$ and $50 \%$ of the tanks in the category have already been sampled.

Low: Over $50 \%$ of the tanks in the category have already been sampled.

\section{Criterion 4: Dryness}

Priority:

Low

Data Source:

The primary source of data for this criterion is the Hanford Waste Tank Preliminary Dryness Evaluation (Husa et al. 1995). The document evaluated the potential for any waste tank to have a dry layer. The two data sources that determined the dryness of the tanks were photographs of the waste surface and, where available, recent sample information for moisture. These sources give the highest assurance that tanks are currently wet or dry. Other sources of information were temperature (from surveillance thermocouple information), total waste and supernate level readings (surveillance), pumpable liquid content, and diatomaceous earth additions.

Tank Ranking: The method used to assign priority to each tank is discussed in Husa et al. Each tank was ranked as dry, damp, or wet based upon visual images (still or video) of the surface of the waste. After the initial visual classification, all tanks were evaluated against six criteria:

1. Pumpable liquids less than $20 \%$ of the total volume

2. Supernatant less than $5,110 \mathrm{~L}(1,350 \mathrm{gal})$

3. Saltcake greater than $20 \%$ of the waste

4. Surface level less than $1 \mathrm{~m}$ (40 in.)

5. Maximum temperature in the last year greater than $38^{\circ} \mathrm{C}$

6. Diatomaceous earth additions.

Depending upon the total number of "hits" by the above criteria, the tank was classified as having a low, medium, or high probability of being a dry tank. 
Criterion 5: Vapor Flammability

Priority: Low

Data Source: The criterion used to determine the priority of tanks for vapor flammability is the same criterion used for the flammable gas issue. If a tank is within the scope of the flammable gas issue, it is also given priority for safety screening.

Tank Ranking: All tanks within the scope of the flammable gas issue were assigned a high priority for this criterion. All other tanks were assigned a low priority. No medium ranking priority was provided.

\subsection{VAPOR SCREENING CRITERIA}

All tanks need to be screened for vapor issues to satisfy information needs specified in the Data Quality Objectives for Tank Hazardous Vapor Safety Screening (Osborne and Buckley 1995). Tanks to be rotary-mode sampled must also satisfy the Rotary Core Vapor Sampling Data Quality Objective (Price 1994), and the Data Quality Objective for Regulatory Requirements for Hazardous and Radioactive Air Emissions Sampling and Analysis (Mulkey and Markillie 1995), as amended by Status of the Current Understanding of the Toxic Air Pollutants (TAPS) and Hanford Tank Farm Vapor Space Characterization; Recommended Path Forward and Justification for Continued RMCS Exhauster Operations (Laws 1996). Tanks to be rotary-mode sampled in the future will be assigned higher priority than all other tanks.

\section{Criterion: Tanks Requiring Rotary-Mode Sampling}

Priority:

Data Source:

Tank Ranking:
High

Tanks that require rotary-mode sampling are documented in the Baseline Sampling Schedule, Change 96-02 (Stanton 1996), which is a schedule of anticipated events for all types of sampling.

All tanks that will require rotary-mode sampling in the future will be assigned high priority for vapor screening. All other tanks will be assigned a low priority. 


\subsection{VAPOR SPACE PHENOMENOLOGY CRITERIA}

Seven tanks are within the scope of the vapor space phenomenology issue study: four tanks support the temporal vapor study, three tanks support the vapor mixing study, and one tank supports the ventilation rate study (tank 241-S-102 is within the scope of two studies). The temporal, mixing, and ventilation rate studies become the criteria for tank selection for the vapor phenomenology issue.

The seven tanks that support the vapor space phenomenology studies are of equal priority. The vapor samples are required at specific times of the year (listed below when applicable). Because of the specificity of tanks required to support the vapor space phenomenology issue and the schedules involved, criteria used to select tanks will be provided in a slightly different format. Tanks are listed below with the vapor phenomenological study that is supported by vapor sampling of the selected tanks.

\section{Vapor Sample of Tanks 241-BX-104, 241-BY-108, 241-C-107, and 241-S-102}

Date Sample Needed: Summer, Fall, and Winter 1996

Priority:

Phenomenology Study:
High

The composition of these tanks will be measured four times over one year for the temporal study. One extra sample will be taken at the same time of the year as the first sample to see whether any changes occurred in the vapor composition. Sampling from the winter of 1995 and the spring of 1996 has occurred for tanks 241-BY-108, 241-C-107, and 241-S-102. Because tank 241-BX-104 was not sampled in the winter and spring of 1996, it will need to be sampled in the spring and summer of 1997 . These tanks were selected for their diversity so that the observations from this subset of tanks can be used as indicators of behavior in other tanks. In summary, tank $241-\mathrm{C}-107$ is a hot, high humidity, sludge tank with relatively low concentrations of organic vapors and three principle waste gases (hydrogen, ammonia, and nitrous oxide). Tank 241-BY-108 has the highest recorded concentrations of ammonia sampled to date and the second highest total organic vapor concentration. Tank 241-S-102 has primarily saltcake waste, relatively high hydrogen and nitrous oxide concentrations, and moderate levels of organic vapors. It is also the only representative of the 200 West tank farms, which tend to have a higher proportion of volatile alcohols. Tank 241-BX-104 was 
chosen because it is relatively cool, and based upon previous sampling, it appears to have either an unexpectedly high ventilation rate or a very dry surface.

2. Vapor Sample of Tanks 241-B-103, 241-TY-103, and 241-U-112

Date Sample Needed: October 1996

Priority:

High

Phenomenology Study: For each tank, vapor samples for the mixing study will be taken from two separate risers at three different levels in the tank. Based on surveillance information, tanks with the coolest waste were selected. Sampling for the mixing study will be done in October because the ground temperature above the tanks will be warmer than the waste in the tanks; a situation that does not produce thermally-induced convection.

3. Vapor Sample of Tank 241-S-102

Date Sample Needed: $\quad$ Not specified

Priority:

High

Phenomenology Study: The ventilation rate study will be performed to verify that the method used for measuring the headspace breathing rate is effective. Sulfur hexafluoride and helium will be injected into the dome space, and samples will be taken from the dome space at various times at one location to track the decay in concentration.

\subsection{FERROCYANIDE CRITERIA}

Assuming the recommendation to close out the ferrocyanide safety issue will be accepted by the DOE, there is no current need to select tanks for sampling for this issue. 


\subsection{PRIVATIZATION CRITERIA}

All DSTs and SST 241-C-106 are within the scope of the privatization issue. Certain DST wastes, identified as fitting into waste envelopes defined for the first phase of privatization are given higher priority. Feed envelopes are defined by the type of waste in the tank as follows:

Envelope A: DSSF and NCRW supernatant

Envelope B: high cesium concentration supernatant

Envelope C: CC

Envelope D: high-level waste solids

Priority of tanks for the first phase of privatization is determined based on the order in which a particular tank is expected to be staged and processed. Priority also is based on the earliest date that a particular tank's contents will become (and remain) static, as determined by the Preliminary Low-Level Waste Feed Staging Plan (Certa et al. 1996). This date is when the tank becomes available for use as feed. Finally, a very high priority activity is providing private vendors with waste samples from the four envelopes.

\section{Criterion 1: Sequence for Staging Waste to Private Vendors}

Priority: Medium

Data Source: $\quad$ The sources of data used for this criterion are the Preliminary Low-Level Waste Feed Staging Plan (Certa et al. 1996) and the Phase One High-Level Waste Pretreatment and Feed Staging Plan (Manuel 1996). These plans identify tanks that meet the waste envelopes defined in the draft Request for Proposal (RFP) No. DC-RPO6-96RL133087 TWRS Privatization. The waste envelopes were updated in the final RFP (DOE 1996).

Tank Ranking: The priority of tanks for sampling to support the privatization effort is based upon the order in which the waste is expected to be processed. High priority is given to six tanks fitting into envelope A, one tank fitting into envelope $\mathrm{B}$, and two tanks fitting into envelope C (Certa et al. 1996). Medium priority is given to four tanks fitting into envelope D (Manuel 1996). Low priority is given to other DSTs that fit into the waste envelopes and to DSTs that do not fit into any envelope. 


\section{Criterion 2: Date When DSTs are Available as Feed}

Priority: Medium

Data Source: $\quad$ The reports documenting the availability of DSTs as feed are the Preliminary Low-Level Waste Feed Staging Plan (Certa et al. 1996) and the Phase One High Level Waste Pretreatment and Feed Staging Plan (Manuel 1996).

Tank Ranking: Tank priority for sampling is determined by the date that the contents of a tank will become (and remain) static (the date the tanks are projected to be available for feed). The sooner a tank is available for feed, the higher the priority for sampling. High priority is assigned to DSTs that are expected to be available for feed in Fiscal Year 1996 or 1997. Low priority is assigned to DSTs that are not expected to be available for feed until after Fiscal Year 1997.

NOTE: Tanks that are considered available for feed may be substituted for tanks that would be staged sooner but are not considered available.

\section{Criterion 3: Provide Waste to Private Vendors from Feed Envelopes}

Priority: High

Data Source: The DOE will make available to the private contractor up to ten $125 \mathrm{ml}$ samples from waste envelopes A, B, and C. If included in the current contract, two 50-g dried samples from waste envelope $\mathrm{D}$ will be made available. Samples will be sent to a location of the private vendors choice. Selection of four tanks containing the four waste envelope types is documented in the final RFP (DOE 1996). The four tanks from which samples will be taken are 241-AW-101 (feed stream A), 241-AN-105 (feed stream B), 241-AN-107 (feed stream C), and 241-C-106 (feed stream D). Note that tank 241-AN-105 is actually composed of feed stream A, but the samples will be spiked to represent feed stream B. Substitutes of these tanks providing the correct feed streams may be acceptable.

Tank Ranking: Tanks 241-AW-101, 241-AN-105, 241-AN-107, and 241-C-106 will all be assigned a high priority. All other tanks will be assigned a low priority for this criteria. Note that sampling of the above tanks is expected to occur before the end of Fiscal Year 1996. 


\subsection{PROCESS TESTING - SLUDGE WASHING CRITERIA}

Tanks within the scope of the sludge washing issue are defined in Kupfer et al. (1995). The fundamental characterization need for sludge-washing is to get waste samples from as many of the different waste types as possible for the purpose of process testing (Kupfer et al. 1995). Although some waste types have a higher priority than others, all tank waste types need to be considered. REDOX waste is of particular interest because it contributes significantly to the total sludge volume and is expected to contain bounding values of a number of analytes that limit glass production. Sludge waste is more important than saltcake for pretreatment because the insoluble sludge contributes to the volume of HLW product. Other criteria used to determine the priority of tanks for the sludge washing issue are tanks that self-boiled and tanks with high chromium and aluminum inventories.

It is important to note that the following criteria are not the criteria used to select tanks to be within the scope of sludge washing. Selection of tanks to study for sludge washing was done in Kupfer et al. (1995), and the following criteria only help determine the priority of those tanks.

\section{Criterion 1: Fill History}

Priority: High

Data Source: The data source used for this criterion is the tank layering model (Agnew 1996b).

Tank Ranking: High priority assigned to tanks that are predicted to contain over $40 \%$ (by volume) early REDOX (R1) or later REDOX (R2/RSitCk) waste types.

Medium priority assigned to all tanks that are predicted to contain non-REDOX sludge as the primary waste (over $40 \%$ by volume).

Low priority assigned to all tanks that are predicted to contain evaporator bottoms (saltcake or salt slurry) as the primary waste type (over $40 \%$ by volume).

\section{Criterion 2: Key Analyte - Chromium}

Priority: High

Data Source: Chromium estimates were taken from the historical tank content estimates of Agnew (1996b). 
Tank Ranking: The priority of the tanks was based on the estimate of chromium in the tanks:

High: Chromium > 75,000 ppm

Medium: Chromium $\leq 75,000 \mathrm{ppm}$ and $\geq 5,000 \mathrm{ppm}$

Low: Chromium $<5,000 \mathrm{ppm}$

Criterion 3: Key Analyte - Aluminum

Priority: Medium

Data Source: Aluminum estimates were taken from the historical tank content estimates of Agnew (1996b).

Tank Ranking: The priority of the tanks was based on the estimate of aluminum in the tanks:

High: Aluminum $>50,000 \mathrm{ppm}$

Medium: Aluminum $\leq 50,000 \mathrm{ppm}$ and $\geq 25,000 \mathrm{ppm}$

Low: Aluminum $<25,000 \mathrm{ppm}$

Criterion 4: Self-Boiling Tanks (REDOX Waste Only)

Priority: $\quad$ Medium

Data Source: $\quad$ The tanks in the S and SX Farms that have self-boiled in the past are summarized in Waste Status and Transaction Record Summary for the Southwest Quadrant of the Hanford 200 East Area (Brevick et al. 1995). Very good records have been kept as to which tanks have experienced self boiling and which tanks received self-boiling waste.

Tank Ranking: High priority was assigned to all S and SX Farm tanks that were recorded as self boiling or received self-boiling waste, and experienced large waste level decreases. Low priority was assigned to all other tanks. 


\section{Criterion 5: High Sludge Inventory}

Priority: Medium

Data Source: The data source for determining the total inventory of sludge in the tank is the tank layering model (Agnew 1996b).

Tank Ranking: High: Sludge inventory is $>567 \mathrm{~m}^{3}(150 \mathrm{kgal})$.

Medium: Sludge inventory is between $190 \mathrm{~m}^{3}(50 \mathrm{kgal})$ and $567 \mathrm{~m}^{3}$.

Low: Sludge inventory is $<190 \mathrm{~m}^{3}$.

\section{Criterion 6: High Saltcake Inventory}

Priority: Low

Data Source: The data source for determining the total inventory of sludge in the tank is the tank layering model (Agnew 1996b).

Tank Ranking: High: Saltcake inventory is $>567 \mathrm{~m}^{3}$ (150 kgal).

Medium: Saltcake inventory is between $190 \mathrm{~m}^{3}(50 \mathrm{kgal})$ and $567 \mathrm{~m}^{3}$.

Low: Saltcake inventory is $<190 \mathrm{~m}^{3}$.

\subsection{PROCESS TESTING - SUPERNATANT PRETREATMENT CRITERIA}

The tanks that are within the scope of the supernatant pretreatment issue are DSTs containing DSSF, CC, NCAW, and NCRW waste types (see Section 3.1.9 for waste type definitions). When selecting tanks for the supernatant pretreatment issue, it is important to have a representative sampling for all four of these waste types. It is more beneficial to sample one tank from each of DSSF, CC, NCAW, and NCRW waste types rather than sampling just DSSF and CC tanks (the most important waste types). 


\section{Criterion 1. Tanks with DSSF Waste Type}

Priority: High

Data Source: $\quad$ Tanks containing DSSF waste are recorded in the Waste Tank Summary Report for Month Ending February 29, 1996 (Hanlon 1996).

Tank Ranking: $\quad$ Tanks containing DSSF waste will be assigned a high priority for this criteria. All other tanks will be assigned a low priority.

Criterion 2. Tanks with CC Waste Type

Priority: High

Data Source: Tanks containing CC waste are recorded in Hanlon (1996).

Tank Ranking: Tanks containing CC waste will be assigned a high priority for this criteria. All other tanks will be assigned a low priority.

\section{Criterion 3. Tanks with NCAW Waste Type}

Priority: Medium

Data Source: $\quad$ Tanks containing NCAW waste are recorded in Hanlon (1996), which designates NCAW waste tanks as "Aging."

Tank Ranking: Tanks containing NCAW waste will be assigned a high priority for this criteria. All other tanks will be assigned a low priority.

\section{Criterion 4. Tanks with NCRW Waste Type}

Priority: Low

Data Source: $\quad$ Tanks containing NCRW waste are recorded in Hanlon (1996), which designates NCRW waste as "DN/PD" (Dilute Noncomplexed/PUREX Decladding).

Tank Ranking: Tanks containing NCRW waste will be assigned a high priority for this criteria. All other tanks will be assigned a low priority. 


\subsection{RETRIEVAL CRITERIA}

The tanks that are within the scope of the retrieval function are determined from schedules of future retrieval operations. Characterization needs for retrieval have a high impact on schedules for retrieval projects and tank waste retrieval operations. Sampling schedules are determined from retrieval project design information need dates and waste retrieval operation process information needs.

A high priority is assigned to tanks that have near-term needs for sampling that support retrieval (before the end of Fiscal Year 1997). A low priority is assigned to tanks that have long-term needs for sampling that support retrieval (after Fiscal Year 1997).

Because of the specificity of retrieval characterization needs, tanks that require characterization information for retrieval are listed below in a slightly different format than for other issues. The date by which the sample is required and priority of the sampling event is specified. In addition, the specific retrieval operation that the sample information supports is listed for each tank.

\section{Tank 241-AY-102 Grab Samples}

Date Sample Needed: $\quad$ October 1996

Priority: High

Retrieval Operation: $\quad$ Retrieval of tank 241-C-106. Grab samples of tank 241-AY-102 are required during the tank 241-C-106 Sluicing Initial SST Retrieval Demonstration. There is a need to confirm that the waste leakage limit has not been exceeded, and the solids transfer goal is met. There is also a need to determine whether the suspended solids and radiological material concentration in tank 241-AY-102 aqueous waste exceeds the operational basis. The process grab sample requirements for tank 241-AY-102 will be identified in the process control plan for tank 241-C-106.

\section{Tank 241-AZ-101 Grab Samples}

Date Sample Needed: September 1996

Priority: High

Retrieval Operation:

Tank 241-AZ-101 mixer pump process test. There is a need to take percent dry solids from tank 241-AZ-101 grab samples before, during, and immediately after the 
sludge mobilization process test, which is scheduled to start September 1996. There is also a need for in situ measurement of sludge shear strength by September 1996 as identified in Bloom and Nguyen (1995).

\section{Tanks 241-AX-104 and 241-C-106 Core Samples}

Date Sample Needed:

Priority:

Retrieval Operation:
April 1997

High

The Hanford Tanks Initiative (HTI) program needs waste samples for characterizing the heel in tank 241-AX-104 and the hard heel of tank 241-C-106. There is a need to determine what acquired commercial technology is required to remove the residual hard heel in tank 241-C-106 after initial sluicing retrieval. There is also a need to determine the amount and type of remaining waste in tank $241-\mathrm{AX}-104$ for specification of closure requirements. Similar information will be required for tank 241-C-106 closure after final retrieval.

\section{Tank 241-AX-103 Core Sample}

Date Sample Needed: $\quad$ March 1998

Priority: Low

Retrieval Operation: Initial SST retrieval system design. To have data by October 1998 there is a need for a sample from tank 241-AX-103 by March 1998. Detailed design of retrieval systems begins in October 1998. Specific questions to be answered by characterization information are:

1. Are predicted emissions or release gases within the design envelope (vapor sampling issue)?

2. Will retrieval operations be within the safety basis?

3. Is the radiological inventory within the safety basis? 
4. Is the hazardous material inventory within the assumed envelope of the safety basis?

5. Is the retrieved waste compatible with waste in the receiving tank?

\subsection{HISTORICAL MODEL EVALUATION CRITERIA}

The tanks that are within the scope of the HDW model (Agnew 1996b) evaluation are those listed in the Historical Model Evaluation Data Requirements (Simpson and McCain 1996). The criterion used to determine priority of tanks for the historical model evaluation are tanks with REDOX, saltcake, PUREX, and uranium recovery wastes; and tanks with a high predicted vertical variability. Finally, tanks with many available risers for sampling are given priority (to be able to measure horizontal variability). Tanks with bismuth phosphate waste are not given priority for the historical model evaluation issue because many tanks containing bismuth phosphate waste have already been sampled.

\section{Criteria 1-4: Typical REDOX, Saltcake, PUREX, and UR Waste}

Priority: $\quad$ Typical REDOX waste - High

Typical saltcake waste - High

Typical PUREX waste - Medium

Typical uranium recovery waste - Medium

Data Source: $\quad$ The tank layering model (Agnew 1996b) was used to select tanks with large predicted amounts of REDOX, saltcake, PUREX, and uranium recovery wastes. It should be noted that the purpose of the historical model evaluation DQO is to evaluate the accuracy of the HDW model (including the tank layering model).

Tank Ranking: $\quad$ Each tank was assigned priority based on the estimated likelihood the waste was present in significant quantity.

Low: REDOX, saltcake, PUREX, or uranium recovery waste is not expected to be in the tank.

Medium: Particular waste type is present but is $<50 \%$ of the total.

High: Particular waste type is present and represents $50 \%$ or more of the total waste. Tanks with uncomplicated process histories were identified as generally more desirable. Tanks with overall high volumes of wastes were preferred. Tanks possessing single waste layers at least $1 \mathrm{~m}$ (40 in.) in depth, or 
tanks with the desired waste layer situated on the top were selected. The criterion of approximately $1 \mathrm{~m}$ was selected because that depth constitutes slightly more than two $48-\mathrm{cm}$ (19-in.) segments as provided by the rotary-mode or push-mode core sampling systems. If the waste layer is greater than two segments deep, one core segment should contain the single waste type of interest with limited mixing of other waste types.

\section{Criterion 5: Vertical Spatial Variability}

Priority: Medium

Data Source: $\quad$ The tank layering model (Agnew 1996b) was used to evaluate tanks for the criterion of vertical spatial variability.

Tank Ranking: $\quad$ Each tank was assigned a priority based on the number of discemable layers (over $50,000 \mathrm{gal}$, or over $10,000 \mathrm{gal}$ if on the surface). This criterion complements criteria $1-4$, which require thick layers of specific waste types. The vertical spatial variability criterion still requires thick layers but favors tanks where thick layers of more than one waste type may be obtained so that information can be gained on several waste types in a single sampling event.

Low: One discernable layer.

Medium: Two or three layers.

High: Four or more layers.

NOTE: Tanks with more than five discernable layers are possible but highly unlikely.

\section{Criterion 6: Ability to Measure Horizontal Spatial Variability}

Priority: Low

Data Source: Criterion 6 is different from criterion 5, because priority is determined based on the ability to measure the horizontal variability in the tank rather than setting priorities based on predictable vertical variability in the tank. Horizontal variability is much more difficult to observe than vertical variability. The ability to measure horizontal variability depends on how many risers are available to sample from, and how well those risers are distributed. Riser availability information comes from two 
different sources. The first is the Riser Configuration Document for Single-Shell Waste Tanks (Alstad 1993). This document contains riser information (for all SSTs) about what equipment is in each riser, and which risers have no equipment (spare). An estimate of riser availability can be made by counting the number of spare risers. This estimate is often low because some equipment can be removed for sampling. The second source of information about riser availability is Waste Tank Risers Available for Sampling (Lipnicki 1995), which records information obtained from field inspections of the tanks.

Tank Ranking

Each tank was assigned a priority based on the availability of risers in the tanks. The number of risers available in the center of the tank was also considered, because a good estimate of horizontal variability can be gained by considering estimates from both the sides and middle of the tank.

Low: Only one or two risers are available from the side of the tank.

Medium: Three or four risers are available, or two risers are available, one of which is in the center portion of the tank (within one-half of the total radius of the tank from the center).

High: Five or more risers are available, or three or more risers are available one of which is in the center of the tank. 
WHC-SD-WM-TA-164 Rev. 2

This page intentionally left blank. 


\subsection{ISSUE PRIORITIES}

During the process of determining tank priority for sampling, each TWRS program identified the criteria by which tanks are ranked for a specific issue. However, the relative importance of each issue requiring characterization sampling must be determined to complete the process.

A multi-attribute decision analysis process was applied to all TWRS issues requiring characterization sampling. The multi-attribute decision analysis process involved four steps:

1. Identifying issues that require characterization sampling (see Section 3.0).

2. Determining the range of outcomes associated with sampling for each issue. This step requires an understanding of the best outcome of sampling (assuming that the correct tanks are selected) and the worst outcome of sampling.

3. Ranking issues in order of importance by considering the benefit derived from moving from the worst outcome to the best outcome. It is also necessary to consider the contribution that sampling makes in supporting the best outcome. For some issues, sampling information is a deciding factor; for others it is less important.

4. Assigning weights to the ranked issues indicating the relative importance.

The process of determining issue priorities was completed by representatives of the TWRS programs requiring core sample data, the DOE-RL, and Ecology (Eberlein 1996). The weighted issue priorities determined in the multi-attribute decision analysis process are shown in Table 5-1. Note that the issue weights are normalized between 0 and 10 , whereas the issue weights in Eberlein (1996) are normalized between 0 and 100.

It is important to note that operational issues are included in Table 5-1, although operational issues are not considered in the process of determining tank priorities. (Operational issues are not considered when determining tank priorities because operational functions that require sampling information are schedule driven. In other words, either characterization can support the operational need or it cannot, and tank priority has no meaning). Operational needs must still be incorporated into the final sampling schedule; therefore, an indication of the relative importance of operational issues to the other issues requiring sampling must be documented.

The weighted issue priorities determined in the multi-attribute decision analysis process are used in the spreadsheet that creates the final tank priority list. Details of the spreadsheet matrix are presented in Appendix A. 
Table 5-1. Results of the Multi-Attribute Utility Model Method of Determining Relative Priority of Issues.

\begin{tabular}{|c|c|c|}
\hline Ksstie & Issue Ranle & $\begin{array}{l}\text { relative } \\
\text { isue weight }\end{array}$ \\
\hline Flammable Gas (Safety) & 1 & 10 \\
\hline Organic Phenomenology (Safety) & 2 & 9 \\
\hline $\begin{array}{l}\text { Compatibility and Waste Transfer } \\
\text { (Operations) }^{1}\end{array}$ & 3 & 7.5 \\
\hline Safety Screening (Safety) & 4 & 6.5 \\
\hline Vapor Screening (Safety) ${ }^{2}$ & 5 & 6 \\
\hline Caustic Mitigation (Operations) $^{4}$ & 6 & 4.5 \\
\hline Privatization (Disposal) & 7 & 3.5 \\
\hline Vapor Space Phenomenology (Safety) & 8 & 3.5 \\
\hline Process Testing (Disposal) & 9 & 2.5 \\
\hline Evaporator (Operations) & 10 & 2.5 \\
\hline $\begin{array}{l}\text { Historical Model Evaluation } \\
\text { (Characterization) }\end{array}$ & 11 & 2 \\
\hline Retrieval (Disposal) & 12 & 1 \\
\hline Ferrocyanide (Safety) & 13 & $0^{3}$ \\
\hline
\end{tabular}

Note:

'Compatability (waste transfer) is a combination of two issues identified in Eberlein (1996): waste acceptance and transfers. These issues were combined because they are both addressed by one DQO (Fowler 1995).

${ }^{2}$ Vapor screening is a combination of two issues identified in Eberlein (1996): rotary vapor operations and organic solvents. These issued were combined because they are both addressed by one sampling event, and they will be treated as one issue for characterization purposes.

${ }^{3}$ The issue weight for ferrocyanide was determined in Eberlein (1996) to be 0.5. However, because ferrocyanide has no need for sampling information, the issue weight will be 0 for the characterization technical basis.

"The issue of "Special Test" as reported in Eberlein (1996) will be referred to as caustic mitigation for the characterization technical basis. 


\subsection{TANK PRIORITIES}

\subsection{TANK PRIORITY LIST FOR COMBINED ISSUES}

The tank priority list for sampling for combined issues is shown in Table 6-1. Detailed evaluations for each tank issue are included in Appendix C.

The tank priority list for sampling for combined issues was developed using a spreadsheet. Details of the method used to generate the list are provided in Appendix A.

The first column in Table 6-1 is a list of all tanks (single-shell and double-shell).

Columns 2, 3, and 4 provide a tank priority for each mode of sampling (solid, liquid, and vapor phase sampling, respectively). Columns 2,3 , and 4 were created because most issues are very specific about what type of sampling is required to meet sampling needs.

Columns 5 and 6 show the reasons for screening tanks from consideration on the high priority list. The reasons will be discussed in the next section. The tanks in Table 6-1 were sorted based upon the solids priority number in column 2 .

\subsection{TECHNICAL CONSTRAINTS TO SAMPLING}

After the initial tank priority list was created, screening criteria were applied to remove applicable tanks from consideration on the priority list. Screening criteria will be referred to as "constraints" in this document. When a constraint is applied, the priority ranking of the tank is maintained, but the tank is noted as being constrained. When a tank is constrained, it will not be considered for the high priority list of tanks unless there is a strong justification to sample it. If a constrained tank is considered for the high priority list, justification is provided in Section 7.0.

Operational constraints were not considered in selecting high priority tanks. The tank waste characterization basis only considers technical justification to sample or not sample a tank. Operational constraints will be applied during the creation of the final sampling schedule.

The technical constraints used to remove tanks from the high priority list were number and adequacy of previous samples, number of available risers, and volume of waste in the tanks. Tanks for which one or more of these constraints apply are identified in Table 6-1.

Technical constraints are discussed in this section. 
Table 6-1. Tank Priority List With Technical Constraints. (7 sheets)

\begin{tabular}{|c|c|c|c|c|c|}
\hline (6) & 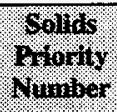 & 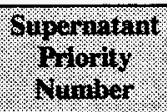 & 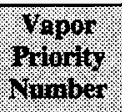 & 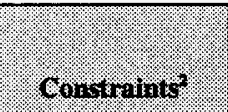 & 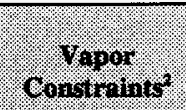 \\
\hline Wos & 100 & 0 & 0 & $\mathrm{~N} / \mathrm{C}$ & DQO Met \\
\hline WOI & 99 & 0 & 0 & $\mathrm{~N} / \mathrm{C}$ & DQO Met \\
\hline $\mathrm{MW} / \mathrm{OH}$ & 91 & 100 & 0 & Samples Taken & $\mathrm{N} / \mathrm{C}$ \\
\hline $4140 \%$ & 85 & 67 & 0 & $\mathrm{~N} / \mathrm{C}$ & $\mathrm{N} / \mathrm{C}$ \\
\hline N 109 & 85 & 89 & 0 & $\mathrm{~N} / \mathrm{C}$ & $\mathrm{N} / \mathrm{C}$ \\
\hline $\mathrm{gr} / \mathrm{OH}$ & 84 & 65 & 0 & Samples Taken & $\mathrm{N} / \mathrm{C}$ \\
\hline AXVOS & 81 & 82 & 0 & Samples Taken & $\mathrm{N} / \mathrm{C}$ \\
\hline S\% 103 & 78 & 0 & 0 & $\mathrm{~N} / \mathrm{C}$ & $\mathrm{N} / \mathrm{C}$ \\
\hline C-104 & 78 & 0 & 0 & $\mathrm{~N} / \mathrm{C}$ & $\mathrm{N} / \mathrm{C}$ \\
\hline 10.09 & 77 & 0 & 0 & Samples Taken & Samples Taken \\
\hline 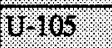 & 70 & 0 & 0 & Samples Taken & DQO Met \\
\hline $\mathrm{H} \times \mathrm{WO}$ & 70 & 0 & 0 & $\mathrm{~N} / \mathrm{C}$ & Samples Taken \\
\hline Urop & 70 & 0 & 0 & Samples Taken & DQO Met \\
\hline $\mathrm{U}-102$ & 69 & 0 & 0 & Samples Taken & $\mathrm{N} / \mathrm{C}$ \\
\hline AN-107 & 66 & 91 & 0 & Samples Taken & $\mathrm{N} / \mathrm{C}$ \\
\hline $1 / 108$ & 66 & 0 & 0 & Samples Taken & Samples Taken \\
\hline BX-110 & 65 & 0 & 0 & Need more sample & Samples Taken \\
\hline A-102 & 65 & 0 & 0 & DQOs Met & Samples Taken \\
\hline BY-102 & 65 & 0 & 0 & Samples Taken & Samples Taken \\
\hline $1 \%(1 / 8$ & 62 & 0 & 0 & $\mathrm{~N} / \mathrm{C}$ & DQO Met \\
\hline $5 \times 106$ & 62 & 0 & 0 & $\mathrm{~N} / \mathrm{C}$ & $\mathrm{N} / \mathrm{C}$ \\
\hline S-106 & 60 & 0 & 0 & $\mathrm{~N} / \mathrm{C}$ & $\mathrm{N} / \mathrm{C}$ \\
\hline$S Y / 03$ & 59 & 46 & 0 & Samples Taken & $\mathrm{N} / \mathrm{C}$ \\
\hline $18 Y-108$ & 58 & 0 & 37 & DQOs Met & DQO Met \\
\hline BX-105 & 58 & 0 & 0 & Samples Taken & Samples Taken \\
\hline C-107 & 56 & 0 & 37 & DQOs Met & DQO Met \\
\hline BY-101 & 55 & 0 & 63 & $\mathrm{~N} / \mathrm{C}$ & $\mathrm{N} / \mathrm{C}$ \\
\hline
\end{tabular}


Table 6-1. Tank Priority List With Technical Constraints. (7 sheets)

\begin{tabular}{|c|c|c|c|c|c|}
\hline monk & 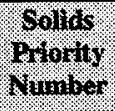 & 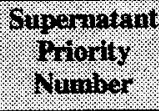 & 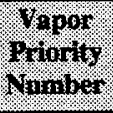 & 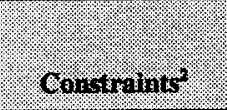 & 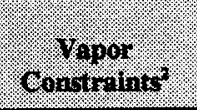 \\
\hline A-103 & 54 & 0 & 0 & $\mathrm{~N} / \mathrm{C}$ & Samples Taken \\
\hline 10106 & 53 & 0 & 0 & Samples Taken & DQO Met \\
\hline S.KX & 50 & 0 & 0 & Need more sample & DQO Met \\
\hline AY-101 & 50 & 56 & 0 & Samples Taken & $\mathrm{N} / \mathrm{C}$ \\
\hline $6 / 14 \%$ & 49 & 0 & 0 & $\mathrm{~N} / \mathrm{C}$ & DQO Met \\
\hline BY-109 & 49 & 0 & 0 & $\mathrm{~N} / \mathrm{C}$ & $\mathrm{N} / \mathrm{C}$ \\
\hline TY-102 & 48 & 0 & 0 & $\mathrm{~N} / \mathrm{C}$ & Samples Taken \\
\hline $5 \times 101$ & 48 & 0 & 0 & $\mathrm{~N} / \mathrm{C}$ & $\mathrm{N} / \mathrm{C}$ \\
\hline C 106 & 48 & 0 & 0 & DQOs Met & DQO Met \\
\hline $10+102$ & 47 & 0 & 0 & DQOs Met & DQO Met \\
\hline AW-104 & 47 & 35 & 0 & Need more sample & $\mathrm{N} / \mathrm{C}$ \\
\hline 6102 & 47 & 0 & 37 & Samples Taken & DQO Met \\
\hline C-202 & 46 & 0 & 0 & Need more sample & $\mathrm{N} / \mathrm{C}$ \\
\hline B-102 & 43 & 0 & 0 & Need more sample & Samples Taken \\
\hline $8 \times 10_{4}$ & 41 & 0 & 0 & $\mathrm{~N} / \mathrm{C}$ & $\mathrm{N} / \mathrm{C}$ \\
\hline B) $10 \%$ & 40 & 0 & 0 & Samples Taken & DQO Met \\
\hline 8106 & 39 & 62 & 0 & Need more sample & $\mathrm{N} / \mathrm{C}$ \\
\hline 18.103 & 39 & 0 & 100 & DQOs Met & DQO Met \\
\hline S-107 & 39 & 0 & 0 & Samples Taken & $\mathrm{N} / \mathrm{C}$ \\
\hline$S-101$ & 39 & 0 & 0 & Samples Taken & $\mathbf{N} / \mathrm{C}$ \\
\hline$B Y=10$ & 38 & 0 & 0 & Samples Taken & DQO Met \\
\hline SX-108 & 38 & 0 & 63 & Need more sample & $\mathrm{N} / \mathrm{C}$ \\
\hline TX-111 & 38 & 0 & 0 & $\mathrm{~N} / \mathrm{C}$ & Samples Taken \\
\hline $1 \times 105$ & 37 & 0 & 0 & $\mathrm{~N} / \mathrm{C}$ & DQO Met \\
\hline $8 \times-112$ & 37 & 0 & 0 & $\mathrm{~N} / \mathrm{C}$ & $\mathrm{N} / \mathrm{C}$ \\
\hline$c-102$ & 37 & 0 & 0 & Need more sample & DQO Met \\
\hline $1 Y>106$ & 37 & 0 & 0 & Need more sample & DQO Met \\
\hline
\end{tabular}


Table 6-1. Tank Priority List With Technical Constraints. (7 sheets)

\begin{tabular}{|c|c|c|c|c|c|}
\hline Tontks? & $\begin{array}{l}\text { Solitis: } \\
\text { Iminority } \\
\text { Number }\end{array}$ & $\begin{array}{l}\text { Supernatant } \\
\text { Prionily. } \\
\text { Number }\end{array}$ & 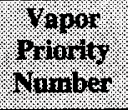 & Constralints? & congroring \\
\hline 1-111: & 37 & 0 & 0 & DQOs Met & DQO Met \\
\hline Xx-103. & 37 & 0 & 0 & $\mathrm{~N} / \mathrm{C}$ & Samples Taken \\
\hline$S-110$ & 36 & 0 & 63 & Samples Taken & Samples Taken \\
\hline BY 1O4 & 36 & 0 & 0 & Samples Taken & DQO Met \\
\hline TY 104 & 35 & 0 & 0 & DQOs Met & DQO Met \\
\hline S.IT2 & 34 & 0 & 0 & $\mathrm{~N} / \mathrm{C}$ & Samples Taken \\
\hline AN-102 & 31 & 78 & 0 & Samples Taken & $\mathrm{N} / \mathrm{C}$ \\
\hline A-106 & 31 & 0 & 63 & $\mathrm{~N} / \mathrm{C}$ & $\mathrm{N} / \mathrm{C}$ \\
\hline $5 x-105$ & 31 & 0 & 0 & $\mathrm{~N} / \mathrm{C}$ & $\mathrm{N} / \mathrm{C}$ \\
\hline BY 107 . & 31 & 0 & 0 & Samples Taken & DQO Met \\
\hline SX 109 & 30 & 0 & 0 & $\mathrm{~N} / \mathrm{C}$ & $\mathrm{N} / \mathrm{C}$ \\
\hline TX-110 & 30 & 0 & 63 & $\mathrm{~N} / \mathrm{C}$ & $\mathrm{N} / \mathrm{C}$ \\
\hline S-104 & 28 & 0 & 0 & Samples Taken & $\mathrm{N} / \mathrm{C}$ \\
\hline TX-116 & 27 & 0 & 63 & $\mathrm{~N} / \mathrm{C}$ & $\mathrm{N} / \mathrm{C}$ \\
\hline SX-107 & 27 & 0 & 63 & $\mathrm{~N} / \mathrm{C}$ & $\mathrm{N} / \mathrm{C}$ \\
\hline AZ-101 & 26 & 63 & 0 & Need more sample & $\mathrm{N} / \mathrm{C}$ \\
\hline U 203 & 26 & 0 & 0 & DQOs Met & DQO Met \\
\hline W-204 & 26 & 0 & 0 & DQOs Met & DQO Met \\
\hline SX-110 & 26 & 0 & 0 & $\mathrm{~N} / \mathrm{C}$ & $\mathrm{N} / \mathrm{C}$ \\
\hline TX-113 & 25 & 0 & 63 & $\mathrm{~N} / \mathrm{C}$ & $\mathrm{N} / \mathrm{C}$ \\
\hline BX-111 & 25 & 0 & 63 & $\mathrm{~N} / \mathrm{C}$ & $\mathrm{N} / \mathrm{C}$ \\
\hline BY 111 & 25 & 0 & 0 & $\mathrm{~N} / \mathrm{C}$ & DQO Met \\
\hline $\mathrm{BX}-112$ & 24 & 0 & 0 & Samples Taken & $\mathrm{N} / \mathrm{C}$ \\
\hline $\mathrm{T}-104$ & 24 & 0 & 0 & Samples Taken & Samples Taken \\
\hline TX-106 & 24 & 0 & 63 & $\mathrm{~N} / \mathrm{C}$ & $\mathrm{N} / \mathrm{C}$ \\
\hline TX-104 & 24 & 0 & 63 & $\mathrm{~N} / \mathrm{C}$ & $\mathrm{N} / \mathrm{C}$ \\
\hline TX-102 & 22 & 0 & 63 & $\mathrm{~N} / \mathrm{C}$ & $\mathrm{N} / \mathrm{C}$ \\
\hline
\end{tabular}


Table 6-1. Tank Priority List With Technical Constraints. (7 sheets)

\begin{tabular}{|c|c|c|c|c|c|}
\hline ininis & 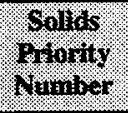 & 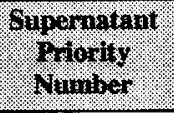 & $\begin{array}{l}\text { Wopr } \\
\text { riums } \\
\text { nomber }\end{array}$ & (6on & (jograr \\
\hline B-111 & 22 & 0 & 0 & Samples Taken & $\mathrm{N} / \mathrm{C}$ \\
\hline TX-101 & 22 & $\overline{0}$ & 63 & $\mathrm{~N} / \mathrm{C}$ & $\mathrm{N} / \mathrm{C}$ \\
\hline B-109 & 21 & 0 & 0 & $\mathrm{~N} / \mathrm{C}$ & $\mathrm{N} / \mathrm{C}$ \\
\hline BY. 103 & 21 & 0 & 0 & Need more sample & DQO Met \\
\hline AN-106 & 20 & 36 & 0 & DQOs Met & $\mathrm{N} / \mathrm{C}$ \\
\hline AW-106 & 20 & 36 & 0 & Need more sample & $\mathrm{N} / \mathrm{C}$ \\
\hline SY-102 & 20 & 36 & 0 & Samples Taken & $\mathrm{N} / \mathrm{C}$ \\
\hline$\overline{B X-103}$ & 20 & 0 & 0 & Need more sample & $\mathrm{N} / \mathrm{C}$ \\
\hline AX-104 & 20 & 0 & 0 & Low Volume & $\mathrm{N} / \mathrm{C}$ \\
\hline BY. 112 & 20 & 0 & 0 & $\mathrm{~N} / \mathrm{C}$ & DQO Met \\
\hline TX-112 & 19 & 0 & 63 & $\mathrm{~N} / \mathrm{C}$ & $\mathrm{N} / \mathrm{C}$ \\
\hline TX-115 & 19 & 0 & 63 & $\mathrm{~N} / \mathrm{C}$ & $\mathrm{N} / \mathrm{C}$ \\
\hline BX-104 & 19 & 0 & 37 & DQOs Met & DQO Met \\
\hline BX-106 & 18 & 0 & 0 & DQOs Met & $\mathrm{N} / \mathrm{C}$ \\
\hline BX-107 & 18 & 0 & 0 & Samples Taken & Samples Taken \\
\hline AY-102 & 18 & 33 & 0 & Need more sample & $N / C$ \\
\hline B-105 & 18 & 0 & 63 & $N / C$ & $\mathrm{~N} / \mathrm{C}$ \\
\hline TY-105 & 18 & 0 & 63 & $\mathrm{~N} / \mathrm{C}$ & $\mathrm{N} / \mathrm{C}$ \\
\hline B-106 & 18 & 0 & 0 & Samples Taken & $\mathrm{N} / \mathrm{C}$ \\
\hline TX-114 & 17 & 0 & 63 & $\mathrm{~N} / \mathrm{C}$ & $\mathrm{N} / \mathrm{C}$ \\
\hline TX-117 & 17 & 0 & 63 & $\mathrm{~N} / \mathrm{C}$ & $\mathrm{N} / \mathrm{C}$ \\
\hline B-104 & 17 & 0 & 0 & Samples Taken & $\mathrm{N} / \mathrm{C}$ \\
\hline B-108 & 17 & 0 & 0 & $\mathrm{~N} / \mathrm{C}$ & $\mathrm{N} / \mathrm{C}$ \\
\hline $\mathrm{T}-109$ & 16 & 0 & 0 & Need more sample & $\mathrm{N} / \mathrm{C}$ \\
\hline A-104 & 16 & 0 & 0 & $\mathrm{~N} / \mathrm{C}$ & $\mathrm{N} / \mathrm{C}$ \\
\hline A-105 & 16 & 0 & 0 & $\mathrm{~N} / \mathrm{C}$ & $\mathrm{N} / \mathrm{C}$ \\
\hline B-112 & 16 & 0 & 0 & DQOs Met & $\mathrm{N} / \mathrm{C}$ \\
\hline
\end{tabular}


Table 6-1. Tank Priority List With Technical Constraints. (7 sheets)

\begin{tabular}{|c|c|c|c|c|c|}
\hline (6. & 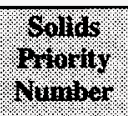 & $\begin{array}{l}\text { Supernakant } \\
\text { DFiority } \\
\text { Number. }\end{array}$ & 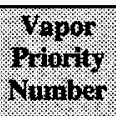 & Gorptrainits? & 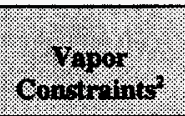 \\
\hline S-103 & 16 & 0 & 0 & $\mathrm{~N} / \mathrm{C}$ & $\mathrm{N} / \mathrm{C}$ \\
\hline$S X-111$ & 16 & 0 & 63 & $\mathrm{~N} / \mathrm{C}$ & $\mathrm{N} / \mathrm{C}$ \\
\hline SX-112 & 16 & 0 & 63 & $\mathrm{~N} / \mathrm{C}$ & $\mathrm{N} / \mathrm{C}$ \\
\hline SX-114 & 16 & 0 & 63 & $\mathrm{~N} / \mathrm{C}$ & $\mathrm{N} / \mathrm{C}$ \\
\hline SX-115 & 16 & 0 & 0 & $\mathrm{~N} / \mathrm{C}$ & $\mathrm{N} / \mathrm{C}$ \\
\hline$S X-113$ & 16 & 0 & 0 & DQOs Met & $\mathrm{N} / \mathrm{C}$ \\
\hline BX-109 & 16 & 0 & 0 & Samples Taken & $\mathrm{N} / \mathrm{C}$ \\
\hline S-105 & 16 & 0 & 0 & $\mathrm{~N} / \mathrm{C}$ & Samples Taken \\
\hline B-110 & 15 & 0 & 0 & Samples Taken & $\mathrm{N} / \mathrm{C}$ \\
\hline T. 107 & 15 & 0 & 0 & DQOs Met & DQO Met \\
\hline B-202 & 15 & 0 & 0 & Samples Taken & $\mathrm{N} / \mathrm{C}$ \\
\hline BX-101 & 15 & 0 & 0 & DQOs Met & $\mathrm{N} / \mathrm{C}$ \\
\hline T-101 & 15 & 0 & 63 & $\mathrm{~N} / \mathrm{C}$ & $\mathrm{N} / \mathrm{C}$ \\
\hline TX-107 & 15 & 0 & 0 & DQOs Met & $\mathrm{N} / \mathrm{C}$ \\
\hline C. 108 & 15 & 0 & 0 & DQOs Met & DQO Met \\
\hline S-109 & 15 & 0 & 0 & Samples Taken & $\mathrm{N} / \mathrm{C}$ \\
\hline T-103 & 14 & 0 & 0 & Need more sample & $\mathrm{N} / \mathrm{C}$ \\
\hline $\mathrm{U}-110$ & 14 & 0 & 0 & Samples Taken & $\mathrm{N} / \mathrm{C}$ \\
\hline B-201 & 14 & 0 & 0 & Samples Taken & $\mathrm{N} / \mathrm{C}$ \\
\hline AZ-102 & 13 & 24 & 0 & Need more sample & $\mathrm{N} / \mathrm{C}$ \\
\hline C.109 & 13 & 0 & 0 & DQOs Met & DQO Met \\
\hline S-108 & 13 & 0 & 0 & $\mathrm{~N} / \mathrm{C}$ & Samples Taken \\
\hline B-101 & 13 & 0 & 0 & DQOs Met & $\mathrm{N} / \mathrm{C}$ \\
\hline $\mathrm{C}-105$ & 13 & 0 & 0 & DQOs Met & $\mathrm{N} / \mathrm{C}$ \\
\hline TX-109 & 13 & 0 & 63 & $\mathrm{~N} / \mathrm{C}$ & $\mathrm{N} / \mathrm{C}$ \\
\hline AW-103 & 12 & 30 & 0 & Samples Taken & $\mathrm{N} / \mathrm{C}$ \\
\hline AW-105 & 12 & 30 & 0 & Need more sample & $\mathrm{N} / \mathrm{C}$ \\
\hline
\end{tabular}


WHC-SD-WM-TA-164 Rev. 2

Table 6-1. Tank Priority List With Technical Constraints. (7 sheets)

\begin{tabular}{|c|c|c|c|c|c|}
\hline Tonis's & 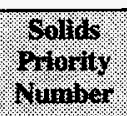 & 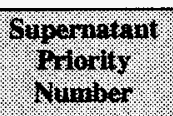 & 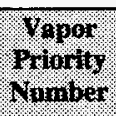 & 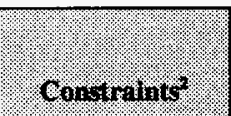 & congraing \\
\hline (1.112. & 12 & 0 & 0 & DQOs Met & DQO Met \\
\hline BX-108 & 11 & 0 & 0 & Samples Taken & $\mathrm{N} / \mathrm{C}$ \\
\hline $\mathrm{C}-203$ & 11 & $\overline{0}$ & 0 & DQOs Met & $\mathrm{N} / \mathrm{C}$ \\
\hline 1.110 & 11 & 0 & 0 & $\mathrm{~N} / \mathrm{C}$ & Samples Taken \\
\hline TX-108 & 11 & 0 & 63 & $\mathrm{~N} / \mathrm{C}$ & $\mathrm{N} / \mathrm{C}$ \\
\hline $\mathrm{T}-108$ & 11 & 0 & 0 & DQOs Met & $\mathrm{N} / \mathrm{C}$ \\
\hline B-107 & 10 & 0 & 63 & $\mathrm{~N} / \mathrm{C}$ & $\mathrm{N} / \mathrm{C}$ \\
\hline$T-105$ & 10 & 0 & 0 & Samples Taken & $\mathrm{N} / \mathrm{C}$ \\
\hline TX-103 & 10 & 0 & 63 & $\mathrm{~N} / \mathrm{C}$ & $\mathrm{N} / \mathrm{C}$ \\
\hline U-101 & 10 & 0 & 0 & Samples Taken & $\mathrm{N} / \mathrm{C}$ \\
\hline T-204 & 10 & 0 & 63 & $\mathrm{~N} / \mathrm{C}$ & $\mathrm{N} / \mathrm{C}$ \\
\hline $\mathrm{C}-110$ & 8 & 0 & 0 & DQOs Met & DQO Met \\
\hline $\mathrm{T}-112$ & 8 & 0 & 0 & $\mathrm{~N} / \mathrm{C}$ & $\mathrm{N} / \mathrm{C}$ \\
\hline BX-102 & 8 & 0 & 63 & $\mathrm{~N} / \mathrm{C}$ & $\mathrm{N} / \mathrm{C}$ \\
\hline C-101 & 8 & 0 & 0 & Need more sample & DQO Met \\
\hline \%.11 & 8 & 0 & 0 & DQOs Met & DQO Met \\
\hline C-201 & 8 & 0 & 0 & Need more sample & $\mathrm{N} / \mathrm{C}$ \\
\hline T-201 & 8 & 0 & 63 & $\mathrm{~N} / \mathrm{C}$ & $\mathrm{N} / \mathrm{C}$ \\
\hline $\mathrm{T}-202$ & 8 & 0 & 63 & $\mathrm{~N} / \mathrm{C}$ & $\mathrm{N} / \mathrm{C}$ \\
\hline TY 101 & 8 & 0 & 0 & $\mathrm{~N} / \mathrm{C}$ & DQO Met \\
\hline TY-106 & 8 & 0 & 0 & DQOs Met & $\mathrm{N} / \mathrm{C}$ \\
\hline U-104 & 8 & 0 & 0 & $\mathrm{~N} / \mathrm{C}$ & $\mathrm{N} / \mathrm{C}$ \\
\hline B-203 & 7 & 0 & 0 & DQOs Met & $\mathrm{N} / \mathrm{C}$ \\
\hline B-204 & 7 & 0 & 0 & DQOs Met & $\mathrm{N} / \mathrm{C}$ \\
\hline C-204 & 7 & 0 & 0 & DQOs Met & $\overline{N / C}$ \\
\hline U-112 & 7 & 0 & 100 & $\mathrm{~N} / \mathrm{C}$ & $\mathrm{N} / \mathrm{C}$ \\
\hline $\mathrm{T}-102$ & 5 & 0 & 0 & Samples Taken & $\mathrm{N} / \mathrm{C}$ \\
\hline
\end{tabular}


Table 6-1. Tank Priority List With Technical Constraints. (7 sheets)

\begin{tabular}{|c|c|c|c|c|c|}
\hline (2), & 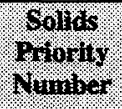 & 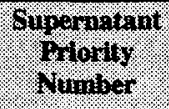 & 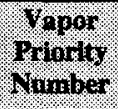 & gomstraintis & . \\
\hline$T-106$ & 5 & 0 & 0 & Samples Taken & $\mathrm{N} / \mathrm{C}$ \\
\hline$T-203$ & 5 & 0 & 63 & $\mathrm{~N} / \mathrm{C}$ & $\mathrm{N} / \mathrm{C}$ \\
\hline $1 \% 103$ & 5 & 0 & 37 & $\mathrm{~N} / \mathrm{C}$ & DQO Met \\
\hline U-201 & 5 & 0 & 0 & DQOs Met & $\mathrm{N} / \mathrm{C}$ \\
\hline $\mathrm{U}-202$ & 5 & 0 & 0 & DQOs Met & $\mathrm{N} / \mathrm{C}$ \\
\hline $\mathrm{AN}-101$ & 0 & 31 & 0 & Samples Taken & $\mathrm{N} / \mathrm{C}$ \\
\hline AP-101 & 0 & 12 & 0 & Samples Taken & $\mathrm{N} / \mathrm{C}$ \\
\hline AP-102 & 0 & 32 & 0 & Samples Taken & $\mathrm{N} / \mathrm{C}$ \\
\hline AP-103 & 0 & 17 & 0 & Samples Taken & $\mathrm{N} / \mathrm{C}$ \\
\hline AP-104 & 0 & 12 & 0 & Samples Taken & $\mathrm{N} / \mathrm{C}$ \\
\hline AP-105 & 0 & 27 & 0 & Samples Taken & $\mathrm{N} / \mathrm{C}$ \\
\hline AP-106 & 0 & 22 & 0 & Need more sample & $\mathrm{N} / \mathrm{C}$ \\
\hline AP-107 & 0 & 17 & 0 & Samples Taken & $\mathrm{N} / \mathrm{C}$ \\
\hline AP-108 & 0 & 12 & 0 & DQOs Met & $\mathrm{N} / \mathrm{C}$ \\
\hline AW-102 & 0 & 36 & 0 & Need more sample & $\mathrm{N} / \mathrm{C}$ \\
\hline
\end{tabular}

Notes:

'Shaded tanks are Watch List tanks.

${ }^{2} \mathrm{~N} / \mathrm{C}=$ not constrained from sampling 


\subsubsection{Number of Samples Previously Taken}

Where more than one previous full-depth (core) sample already has been taken from a tank during or after 1989 , or has been taken prior to July 1, 1996, the tank was constrained. If a tank had more than one previous core sample available, but the samples were taken from the same riser or were inadequate to meet DQOs, the tank was not constrained. This constraint may require tank-by-tank review because the adequacy of previous sample analysis data depends on the issue being addressed.

\subsubsection{Number of Available Risers}

Tanks that only had one riser available were constrained from the priority list. Currently, a minimum of two samples is required to obtain information about horizontal variability in the waste. Information for this constraint was taken from the Riser Configuration Document for Single-Shell Tanks (Alstad 1993) and from a compilation of available and field data (Lipnicki 1995). No tanks were limited by this constraint.

\subsubsection{Volume of Tank Waste}

Tanks containing less than $38 \mathrm{~m}^{3}$ (10 kgal) of waste were constrained from the priority list. Because of their minor contribution to the overall waste volume, issues associated with these tanks were considered less important than issues associated with large-volume tanks. Waste depths are recorded in the surveillance waste tank summary report (Hanlon 1996). This constraint was reviewed on a tank-by-tank basis to ensure that no safety or disposal issues specific to low-volume tanks were overlooked.

\subsection{TANK WASTE ANALYSIS PLAN REQUIREMENTS}

The Tri-Party Agreement (Ecology et al. 1996) directs that a certain number of tank characterization reports (TCRs) be submitted each fiscal year. In Fiscal Year 1997, $40 \mathrm{TCRs}$ are to be submitted. In support of TCR production, the characterization project attempts to sample tanks that have the highest priority possible, for which a new TCR can be written. The Fiscal Year 1997 Tank Waste Analysis Plan (in process) will document which TCRs will be written in Fiscal Year 1997. Table 6-2 is provided to aid in selecting tanks with the highest possible priority for which a TCR still has to be written. The tanks listed below are the tanks that do not have a current TCR written (or will not have a TCR written by the end of Fiscal Year 1996). Table 6-2 also provides the priority number for each tank. 
WHC-SD-WM-TA-164 Rev. 2

Table 6-2. Tanks Available for Tank Waste Analysis Plan. (2 sheets)

\begin{tabular}{|c|c|c|c|}
\hline Tank & Solids Prionity Number & Tank & Solids Priority Number \\
\hline U-103 & 100 & C-102 & 37 \\
\hline A-101 & 99 & AX-103 & 37 \\
\hline AN-103 & 85 & S-110 & 36 \\
\hline AN-104 & 85 & $S-112$ & 34 \\
\hline AN-105 & 81 & A-106 & 31 \\
\hline SX-103 & 78 & SX-105 & 31 \\
\hline C-104 & 78 & BY -107 & 31 \\
\hline$A X-101$ & 70 & $S X-109$ & 30 \\
\hline $\mathrm{U}-102$ & 69 & $\mathrm{TX}-110$ & 30 \\
\hline $\mathrm{U}-108$ & 66 & $\mathrm{TX}-116$ & 27 \\
\hline BY -102 & 65 & SX-107 & 27 \\
\hline TX-118 & 62 & $S X-110$ & 26 \\
\hline SX-106 & 62 & $\mathrm{TX}-113$ & 25 \\
\hline$S-106$ & 60 & $\mathrm{BX}-111$ & 25 \\
\hline BY -101 & 55 & BY-111 & 25 \\
\hline A-103 & 54 & TX-106 & 24 \\
\hline U-106 & 53 & TX-104 & 24 \\
\hline$S-111$ & 50 & TX-102 & 22 \\
\hline U-111 & 49 & TX-101 & 22 \\
\hline BY -109 & 49 & B-109 & 21 \\
\hline TY-102 & 48 & BY -103 & 21 \\
\hline SX-101 & 48 & AX-104 & 20 \\
\hline SX-104 & 41 & BY -112 & 20 \\
\hline $\mathrm{TX}-111$ & 38 & $\mathrm{TX}-112$ & 19 \\
\hline TX-105 & 37 & $\mathrm{TX}-115$ & 19 \\
\hline$S X-102$ & 37 & B-105 & 18 \\
\hline
\end{tabular}




\section{WHC-SD-WM-TA-164 Rev. 2}

Table 6-2. Tanks Available for Tank Waste Analysis Plan. (2 sheets)

\begin{tabular}{|c|c|c|c|}
\hline Trank & Sollds Priority Number & Tank & Solids Prority Number \\
\hline TY-105 & 18 & TX-109 & 13 \\
\hline TX-114 & 17 & T-110 & 11 \\
\hline TX-117 & 17 & TX-108 & 11 \\
\hline B-108 & 17 & B-107 & 10 \\
\hline A-104 & 16 & TX-103 & 10 \\
\hline A-105 & 16 & U-101 & 10 \\
\hline S-103 & 16 & T-204 & 10 \\
\hline SX-111 & 16 & T-112 & 8 \\
\hline SX-112 & 16 & BX-102 & 8 \\
\hline SX-114 & 16 & T-201 & 8 \\
\hline SX-115 & 16 & T-202 & 8 \\
\hline S-105 & 16 & TY-101 & 8 \\
\hline T-101 & 15 & U-104 & 8 \\
\hline S-109 & 15 & U-112 & 7 \\
\hline T-103 & 14 & T-203 & 5 \\
\hline S-108 & 13 & TY-103 & 5 \\
\hline
\end{tabular}


WHC-SD-WM-TA-164 Rev. 2

This page intentionally left blank. 


\subsection{SELECTION OF HIGH PRIORITY TANKS}

High priority tanks were selected from the priority list shown in Table 6-1. These tanks are recommended for early sampling to best meet the needs of the many TWRS programs that require tank sampling information. The high priority tanks are recommended for sampling, after which a decision will be made on how to better direct further characterization efforts. Early sampling of high priority tanks will also expedite resolution of the safety issues.

The high priority list of tanks is not necessarily an exclusive list of tanks to be sampled. It is recognized that to meet requirements outlined in the Tri-Party Agreement (Ecology et al. 1996), additional tanks other than those specified in the high priority list will need to be sampled. The complete list of tanks to be sampled to meet Tri-Party Agreement requirements will be outlined in the forthcoming Tank Waste Analysis Plan. It is also recognized that operational constraints may prevent some high priority tanks from being sampled.

The high priority tanks selected were reviewed for acceptance by the TWRS programs responsible for the issues and the DOE-RL. Table 7-1 lists high priority tanks.

\subsection{APPROACH TO SELECT HIGH PRIORITY TANKS}

The most important consideration when selecting high priority tanks is to ensure that all tank selection criteria listed in Section 4.0 are addressed. By focusing on tanks from the top of the priority list (see Table 6-1), tank selection criteria are addressed using the least number of tanks. Some tanks high on the priority list were not selected as high priority tanks because they address tank selection criteria already addressed by other tanks higher in priority. Likewise, some tanks lower on the priority list were selected as high priority tanks because they were first on the priority list that addressed a certain criteria. In this section, specific sampling needs for the different TWRS issues are discussed.

The primary sampling need for the flammable gas issue was to sample the remaining flammable gas tanks that experience episodic releases of flammable gases. The next most important need was to sample an SST from each flammable gas waste type. When high priority tanks were selected, it was possible to select tanks that covered waste types 1A, 2A, $1 B$, and 2B. No tanks were available for sampling (that could be push-mode sampled) that covered waste types $3 \mathrm{~A}$ and $3 \mathrm{~B}$. However, tanks $241-\mathrm{BY}-105$ and 241-SX-104 cover waste types $3 \mathrm{~A}$ and $3 \mathrm{~B}$, respectively. These tanks require rotary-mode sampling and should be considered high priority when the ability to use the RGS sampler in rotary-mode becomes available. 
The primary sampling need for the organic issue is to sample the rest of the tanks identified in Webb (1995) as being potentially unsafe if drained of their liquids. Of equal importance for the organic issue is to select tanks to sample that are predicted by the HDW model to have high quantities of organic material. Both needs were met in the selection of the high priority tanks.

When safety screening criteria was applied to the tanks, preference was given to tanks that contain waste types that are not well characterized. The waste types, which have not been well characterized, include REDOX sludge, saltcake from the 242-T Evaporator, and various PUREX waste types. When high priority tanks were selected, waste types that were not well characterized were represented. Another consideration for safety screening was to select tanks that are expected to contain a high concentration of plutonium. Tanks 241-C-104, 241-C-106, and 241-TX-118 are high priority tanks that are expected to have high plutonium concentrations.

As with safety screening, sludge washing and historical evaluation issues require characterization of waste types that are not well characterized. By selecting tanks from waste types that are not well characterized for the safety screening issue, the needs of the sludge washing and historical model evaluation issues are also met. The sludge washing issue also intends to study tanks that have self-boiled in the past. Tank 241-SX-101 is a high priority tank that self-boiled in the past.

Although the issue of waste retrieval was a low priority, two tanks were selected for sampling that specifically meet the needs of the retrieval issue: 241-C-106 and 241-AX-104. Although both tanks have lower priority numbers, they were chosen as high priority tanks.

High priority tanks for liquid sampling are selected to meet the needs of the supernatant pretreatment and privatization issues. Although the objectives of the supernatant pretreatment and privatization issues differ significantly, the sampling needs of both issues are very similar. Both issues require sampling of tanks that represent different waste types. For this reason, the high priority tanks selected for liquid sampling represent various DST waste types. In addition to obtaining representative samples of the various DST waste types, tank 241-AY-102 was selected as a high priority tank for liquid sampling to support needs of the retrieval program.

Finally, vapor space phenomenology studies are performed to ensure that sampling for vapor screening represents the true composition of gases in the headspace of the tanks. For this reason, the seven tanks that will be sampled for vapor space phenomenology are considered high priority tanks for vapor sampling. 


\subsection{HIGH PRIORITY TANKS FOR SOLID PHASE SAMPLING}

This section discusses the basis used to select high priority tanks for solid phase sampling. The issues determining the selection of high priority tanks are flammable gas, organic phenomenology, safety screening, process testing (sludge washing), retrieval, and historical model evaluation. The following information is provided for each high priority tank:

1. Priority number for solid phase sampling (see Table 6-1, column 3)

2. Issues supported by solid phase sampling of the tank

3. Type of sampling required (push-mode, push-mode with RGS sampler, rotary-mode, or auger sample)

4. Date sample is required (if applicable).

1. SST 241-U-103

Priority \#: $\quad 100$

Issues: $\quad$ - Hydrogen and organics Watch List

Flammable gas issue: contains waste type 1A (Recknagle 1996), measured headspace gas in the tank

- Organics issue: predicted by Webb (1995) to be unsafe if drained of liquids

Safety screening

Sampling Type: $\quad$ Push-mode core sample using RGS sampler.

Required Date: $\quad$ Must be sampled before and after salt well pumping for the flammable gas issue. Must be sampled no later than March 1997 to meet requirements in DOE-RL (1996).

2. SST 241-A-101

Priority \#: $\quad 99$

Issues: $\quad$ - Hydrogen and organics Watch List

- $\quad$ Flammable gas issue: contains waste type 1B (Recknagle 1996)

- Organic issue

- $\quad$ Safety screening

- $\quad$ Sludge washing: high saltcake inventory

- Historical: contains saltcake and salt slurry from the 242-A Evaporator, has many available risers for sampling

Sampling Type: Push-mode core sample using RGS sampler. 
Required Date: $\quad$ Must be sampled before and after salt well pumping for the flammable gas issue.

3. DST 241-AN-103

Priority \#: $\quad 85$

Issues: $\quad$ - Hydrogen Watch List

- $\quad$ Flammable gas issue: needs to be sampled to complete the study of flammable gas producing DSTs, exhibits periodic release of flammable gas, void meter shows highest recorded void space of any tank Safety screening

Sampling Type: $\quad$ Push-mode core sample using RGS sampler.

Required Date: Must be sampled no later than March 1997 to meet requirements in DOE-RL (1996).

4. DST 241-AN-104

Priority \#: $\quad 85$

Issues: $\quad$ - $\quad$ Hydrogen Watch List

- $\quad$ Flammable gas issue: needs to be sampled to complete the study of flammable gas producing DSTs, exhibits periodic release of flammable gas

Safety screening

Sampling Type: Push-mode core sample using RGS sampler.

Required Date: $\quad$ Must be sampled no later than March 1997 to meet requirements specified in DOE-RL (1996).

\section{SST 241-SX-103}

Priority \#: $\quad 78$

Issues: $\quad$ - Hydrogen and organics Watch List

- $\quad$ Organic issue: tank was predicted by the HDW model to contain significant quantities of organics but not considered a problem in Webb (1995); will be used as a comparison

- $\quad$ Safety screening: contains REDOX saltcake waste which is not well characterized

- Historical: contains large quantity of REDOX saltcake waste 
Sampling Type: $\quad$ Rotary-mode core sample.

Required Date: Unspecified.

6. SST 241-C-104

Priority \#:

78

Issues: $\quad$ - $\quad$ Not on current Watch List

- Organic issue: tank was predicted by the HDW model to contain significant quantities of organics but not considered a problem in Webb (1995); will be used as a comparison Safety screening: predicted by the HDW model to contain large quantities of plutonium; also contains PUREX cladding waste and waste from the thorium campaign that are not well characterized

- $\quad$ Sludge washing: large amount of aluminum predicted in tank.

- Historical: contains PUREX waste and has a complicated vertical profile (many waste types)

Sampling Type: Push-mode core sample.

Required Date: Unspecified.

\section{SST 241-AX-101}

Priority \#: $\quad 70$

Issues: $\quad$ - Hydrogen Watch List but not within the scope of the flammable gas issue for sampling

- Organic issue: tank was predicted by the HDW model to contain significant quantities of organics but not considered a problem in Webb (1995); will be used as a comparison

- $\quad$ Safety screening

- Historical evaluation: tank contains large quantities of saltcake from the 242-A Evaporator

Sampling Type: $\quad$ Rotary-mode core sample.

Required Date: Unspecified. 
8. SST 241-BX-110

Priority \#: $\quad 65$

Issues: $\quad$ - $\quad$ Not on current Watch List

- Organic issue: predicted by Webb (1995) as being potentially unsafe if drained of liquids

- $\quad$ Safety screening

- $\quad$ Sludge washing: tank has high sludge inventory

- Historical evaluation

Sampling Type: Rotary-mode core sample.

Required Date: Unspecified.

\section{SST $241-\mathrm{TX}-118$}

Priority \#: $\quad 62$

Issues: - $\quad$ Ferrocyanide and organic Watch List but ferrocyanide is no longer an issue that requires sampling information

- Organic issue

- Safety screening: contains T2 saltcake waste (not well characterized), passive neutron scans indicate potential high plutonium content (Toffer 1994), the HDW model also predicts high plutonium content (Agnew 1996b)

- $\quad$ Sludge washing

- Historical: Contains saltcake from the 242-T Evaporator and PUREX waste types

Sampling Type: Rotary-mode core sample.

Required Date: $\quad$ Unspecified.

10. SST 241-S-106

Priority \#: $\quad 60$

Issues: $\quad$ - $\quad$ Not on current Watch List

- Flammable gas issue: contains waste type 2A (Recknagle 1996)

- $\quad$ Safety screening

- Historical evaluation

Sampling Type: Push-mode core sample using RGS sampler. 
Required Date: $\quad$ Must be sampled before and after salt well pumping for the flammable gas issue.

\section{SST 241-BY-101}

Priority \#:

Issues: $\quad$ - $\quad$ Not on current Watch List

- Flammable gas issue: contains waste type 2B (Recknagle 1996)

- $\quad$ Safety screening

Sampling Type: $\quad$ Push-mode core sample using RGS sampler.

Required Date: $\quad$ Before salt well pumping for the flammable gas issue.

\section{SST 241-TY-102}

Priority \#:

48

Issues: $\quad$ - $\quad$ Not on current Watch List

- Organic issue: predicted by Webb (1995) as being potentially unsafe if drained of liquids

- Safety screening: contains T2 saltcake waste from 242-T Evaporator (not well characterized)

Sampling Type: Rotary-mode core sample.

Required Date: Unspecified.

\section{SST 241-SX-101}

Priority \#:

Issues:

\section{8}

Hydrogen Watch List but not within the scope of the flammable gas issue for sampling

Safety screening: contains R1 (early REDOX sludge) and

RSItCk (REDOX saltcake), waste types that are not well characterized

- $\quad$ Sludge washing: contains REDOX waste which is expected to be a difficult waste type to process. Tank self-boiled for several years which may have created compounds that are difficult-to-process Historical: REDOX wastes are high priority for the historical issue and tank 241-SX-101 has a complicated vertical profile (many waste types) 
Sampling Type: Rotary-mode core sample.

Required Date: Unspecified.

14. SST 241-C-106

Priority \#:

Issues: $\quad$ - $\quad$ High heat Watch List

- Safety screening: contains many waste types that are not well characterized including uranium recovery, PUREX zircalloy cladding (CWP1), washed PUREX sludge (AR), and B-Plant low-level (BL) waste; estimated by the HDW model as having a high inventory of plutonium

- Retrieval: characterization of "hard heel" in tank 241-C-106 is required for the Hanford Tanks Initiative Program, occurring after the rest of the tank content have been sluiced from the tank Historical evaluation: contains several Purex waste types (see above) as well as uranium recovery waste. Tank has a complicated vertical profile (many waste types)

Sampling Type: To be determined.

Required Date: $\quad$ April 1997 (to support Hanford Tanks Initiative Program objectives, sampling will occur after the tank is sluiced).

15. SST 241-AX-104

Priority \#: $\quad 20$

Issues: - $\quad$ Not on current Watch List

- Safety screening: contains PUREX waste types that are not well characterized

- Retrieval: characterization of heel in tank 241-AX-104 is required for the Hanford Tanks Initiative Program

Sampling Type: Light-duty utility arm.

Required Date: $\quad$ April 1997 (to support Hanford Tanks Initiative Program objectives). 


\subsection{HIGH PRIORITY TANKS FOR LIQUID PHASE (GRAB) SAMPLING}

This section discusses the basis used for the final selection of high priority tanks for liquid phase sampling (grab sampling). The issues determining high priority tanks include safety screening (in tanks that have no solids), privatization, process testing for supernatant pretreatment, and retrieval

Operations needs are met primarily through grab sampling. Operational needs are not considered in the following list of high priority tanks for grab sampling although they are still considered to be important when grab sampling. Operational needs are not considered here because of the dynamic nature of operations where schedules change too often to be considered in this technical basis document. When the scheduling of tanks is done, the relative priority of issues (see Section 5.0 ) will need to be taken into consideration when a decision is made to sample a high priority tank or a tank more conducive to current operations needs.

High priority tanks for grab sampling will be given in the same format as high priority tanks for solid phase sampling (see Section 7.2). Note that priority numbers in this section are liquid phase priority numbers.

1. DST 241-AW-101

Priority \#: $\quad 100$

Issues: - $\quad$ Hydrogen Watch List; tank already has been sampled for the hydrogen issue

- Privatization: provide samples of feed stream $A$ to private contractors; tank is expected to be available early as a feed staging tank

Supernatant pretreatment: contains DSSF waste

Sampling Type: Grab sample.

Required Date: $\quad$ No later than the end of July, 1996 to ensure that feed stream is available to private contractors.

2. DST 241-AN-107

Priority \#: $\quad 91$ 
Issues: $\quad$ - $\quad$ Not on the current Watch List

- Privatization: provide samples of feed stream $\mathrm{C}$ to private contractors; tank is expected to be available early as a feed staging tank

- Supernatant Pretreatment: contains CC waste

Sampling Type: Grab sample.

Required Date: No later than the end of July, 1996 to ensure that feed stream is available to private contractors

3. DST 241-AZ-101

Priority \#:

63

Issues: $\quad$ - $\quad$ Not on the current Watch List

- $\quad$ Retrieval: support mixer pump process test

- Supernatant pretreatment: contains NCAW waste

- Privatization

Sampling Type: Grab sample.

Required Date: Before, during, and after mixer pump process test in September 1996 to support needs of the retrieval program.

4. SST 241-C-106

Priority \#: $\quad 62$

Issues: - $\quad$ Privatization: provide samples of feed stream $\mathrm{D}$ to private contractors

Sampling Type: Grab sample.

Required Date: No later than the end of July, 1996 to ensure that feed stream is available to private contractors.

\section{DST 241-AY-102}

Priority \#:

Issues: $\quad$ - $\quad$ Retrieval: support retrieval of waste in tank 241-C-106

- Privatization 
Sampling Type: Grab sample.

Required Date: October 1996 to support the retrieval program.

\subsection{HIGH PRIORITY TANKS FOR VAPOR PHASE SAMPLING}

This section discusses the basis used for the final selection of high priority tanks for vapor phase sampling. Issues determining high priority tanks include vapor phenomenology and vapor screening.

The seven high priority tanks for vapor screening are provided below. All pertinent information regarding vapor phenomenology tanks (high priority vapor sampling tanks) already has been presented in Section 4.5. A summary of the high priority tanks for vapor sampling is listed below.

\section{1-4. SSTs 241-BX-104, 241-BY-108, 241-C-107, and 241-S-102}

Priority \#: $\quad 37$ (for all four tanks)

Issues: - Vapor phenomenology: temporal study. Tank 241-S-102 also will be used in the ventilation rate study

- Vapor screening

Sampling Type: Vapor sample.

Required Date: $\quad$ Summer, fall, and winter of 1996 to support the temporal study. Tank 241-BX-104 will require further sampling in spring and summer of 1997.

\section{5-7. SSTs 241-B-103, 241-TY-103 and 241-U-112}

Priority \#: $\quad 100$ for tanks 241-B-103 and 241-U-112

37 for tank 241-TY-103

Issues: $\quad$ - Vapor phenomenology: mixing study

- Vapor screening.

Sampling Type: Vapor sample.

Required Date: October 1996 to support the mixing study. 


\subsection{SUMMARY OF HIGH PRIORITY TANKS FOR SAMPLING}

This section summarizes all high priority tanks for sampling listed in Table 7-1. Column 1 lists high priority tanks. Column 2 lists the comparative priority number. Note that the comparative priority number may be different than the priority number in Table 6-1 and in Sections 7.2 through 7.4. Columns 3 and 4 of Table 7-1 show the phase of the waste that is of interest and the sampling method that will be used, respectively. If a sample is to be taken at a specific time, this is listed in Column 5. Watch List tanks are designated in Column 6. Column 7 describes which issue needs are expected to be met by sampling each high priority tank.

The priority number in Table 6-1 and in Sections 7.2 through 7.4 was for a specific sampling type and is useful for comparing the priority of tanks for sampling within the same waste phase (or sampling type). The comparative priority shown in Table 7-1 allows a comparison of the priority of tanks for sampling across the three waste phases (or sampling types). For example, Table 6-1 ranks the liquid sampling priority of tank 241-AW-101 as 100, which indicates that a liquid sample from tank $241-\mathrm{AW}-101$ is the most important liquid sample that could be taken. However, the comparative priority number of the liquid sample for tank 241-AW-101 is 55 (compared to the solid sample comparative priority of 100). This indicates that although tank $241-\mathrm{AW}-101$ is the most important tank for liquid sampling, the priority for solid sampling of tank $241-\mathrm{U}-103$ is twice as important as the liquid sampling priority of tank 241-AW-101.

A final consideration for determining the sampling order is time constraints. Some issues have no deadline for tank sampling, while other issues require sampling information at a specific time. It may be necessary to sample a tank with a lower comparative priority number before a tank with a higher comparative priority number because of time constraints. As mentioned earlier, operational constraints to sampling are not discussed in this document, but they will be addressed in the final sampling schedule. 
Table 7-1. High Priority Tanks for Sampling.

\begin{tabular}{|c|c|c|c|c|c|c|}
\hline Ganil & Gomparingur & phoos & Sampling & Wine agniple requined & Whatol & 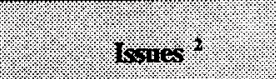 \\
\hline $\mathrm{U}-103$ & 100 & Solid & Push/RGS & $\begin{array}{l}\text { Before salt well pumping } \\
\text { (FG). No later than March } \\
1997 \text { (DOE-RL 1996). }\end{array}$ & $\begin{array}{l}\text { Hydrogen } \\
\text { Organic }\end{array}$ & FG, OR, SS \\
\hline A-101 & 99 & Solid & Push/RGS & $\begin{array}{l}\text { Before salt well pumping } \\
\text { (FG) }\end{array}$ & $\begin{array}{l}\text { Hydrogen } \\
\text { Organic }\end{array}$ & FG, OR, SS, SW, HM \\
\hline AN- 103 & 85 & Solid & Push/RGS & $\begin{array}{l}\text { No later than March } 1997 \\
\text { (DOE-RL 1996) }\end{array}$ & Hydrogen & FG, SS \\
\hline AN-104 & 85 & Solid & Push/RGS & $\begin{array}{l}\text { No later than March } 1997 \\
\text { (DOE-RL 1996) }\end{array}$ & Hydrogen & FG, SS \\
\hline$S X-103$ & 78 & Solid & Rotary & Unspecified & $\begin{array}{l}\text { Hydrogen } \\
\text { Organic }\end{array}$ & OR, SS, HM \\
\hline C-104 & 78 & Solid & Push & Unspecified & None & OR, SS, SW, HM \\
\hline$A X-101$ & 70 & Solid & Rotary & Unspecified & Hydrogen & OR, SS, HM \\
\hline BX-110 & 65 & Solid & Rotary & Unspecified & None & OR, SS, SW, HM \\
\hline TX-118 & 62 & Solid & Rotary & Unspecified & $\begin{array}{l}\text { Ferrocyanide } \\
\text { Organic }\end{array}$ & OR, SS, SW, HM \\
\hline S-106 & 60 & Solid & Push/RGS & $\begin{array}{l}\text { Before salt well pumping } \\
\text { (FG) }\end{array}$ & None & $\mathrm{FG}, \mathrm{SS}, \mathrm{HM}$ \\
\hline BY-101 & 55 & Solid & Push/RGS & $\begin{array}{l}\text { Before salt well pumping } \\
\text { (FG) }\end{array}$ & None & FG, SS \\
\hline
\end{tabular}


Table 7-1. High Priority Tanks for Sampling.

\begin{tabular}{|c|c|c|c|c|c|c|}
\hline Waily & Oompravive & Whaste & Sinping & Hine sumple Requirid & Wacoly & (3) \\
\hline TY-102 & 48 & Solid & Rotary & Unspecified & None & OR, SS, \\
\hline SX-101 & 48 & Solid & Rotary & Unspecified & Hydrogen & SS, SW, HM \\
\hline C-106 & 39 & Solid & $\begin{array}{l}\text { To be } \\
\text { determined }\end{array}$ & April 1997 (R) & High Heat & R, SS, HM \\
\hline AX-104 & 20 & Solid & $\begin{array}{l}\text { Light duty } \\
\text { utility arm }\end{array}$ & April 1997 (R) & None & $\mathrm{R}, \mathrm{SS}$ \\
\hline AW-101 & 55 & Supernatant & Grab & End of July 1996 (PV) & Hydrogen & PV, SP \\
\hline AN-107 & 50 & Supernatant & Grab & End of July 1996 (PV) & None & PV, SP \\
\hline AZ-101 & 35 & Supernatant & Grab & September 1996 (R) & None & PV, R, SP \\
\hline $\mathrm{C}-106$ & 34 & Supernatant & Grab & End of July 1996 (PV) & High Heat & PV \\
\hline AY -102 & 18 & Supernatant & Grab & October 1996 (R) & None & PV, R \\
\hline B-103 & 45 & Vapor & Vapor & October 1996 (VP) & Organic & VS, VP \\
\hline U-112 & 45 & Vapor & Vapor & October 1996 (VP) & None & VS, VP \\
\hline BX-104 & 17 & Vapor & Vapor & $\begin{array}{l}\text { Summer, fall, and winter } \\
1996 \text { and spring and } \\
\text { summer } 1997 \text { (VP) }\end{array}$ & None & VS, VP \\
\hline BY-108 & 17 & Vapor & Vapor & $\begin{array}{l}\text { Summer, fall, and winter } \\
1996 \text { (VP) }\end{array}$ & Ferrocyanide & VS, VP \\
\hline
\end{tabular}


Table 7-1. High Priority Tanks for Sampling.

\begin{tabular}{|c|c|c|c|c|c|c|}
\hline Tank. & $\begin{array}{l}\text { Comparative } \\
\text { Iriority. }\end{array}$ & $\begin{array}{l}\text { Waste } \\
\text { nhase }\end{array}$ & $\begin{array}{l}\text { Sarupling } \\
\text { Type }\end{array}$ & $\begin{array}{l}\text { Tine Sangle Required } \\
\text { (Specing to I Isane) }\end{array}$ & Watch List: & issies: \\
\hline C-107 & 17 & Vapor & Vapor & $\begin{array}{l}\text { Summer, fall, and winter } \\
1996 \text { (VP) }\end{array}$ & None & VS, VP \\
\hline S-102 & 17 & Vapor & Vapor & $\begin{array}{l}\text { Summer, fall, and winter } \\
1996 \text { (VP) }\end{array}$ & $\begin{array}{l}\text { Hydrogen } \\
\text { Organic }\end{array}$ & VS, VP \\
\hline TY-103 & 17 & Vapor & Vapor & October 1996 (VP) & Ferrocyanide & VS, VP \\
\hline
\end{tabular}

Notes:

$\begin{array}{lll}\mathrm{FG} & = & \text { Flammable Gas } \\ \mathrm{HM} & = & \text { Historical Model Evaluation } \\ \mathrm{OR} & = & \text { Organic } \\ \mathrm{PV} & = & \text { Privatization } \\ \mathrm{R} & = & \text { Retrieval } \\ \mathrm{RGS} & = & \text { Retained Gas Sampler }\end{array}$

SS $=$ Safety Screening

SP $=$ Supernatant Pretreatment

$\mathrm{SW}=$ Sludge Washing

VP $=$ Vapor Phenomenology

VS $=$ Vapor Screening 
WHC-SD-WM-TA-164 Rev, 2

This page intentionally left blank. 


\subsection{REFERENCES}

Agnew, S. F., 1996a, History of Organic Carbon in Hanford HLW Tanks: HDW Model, Rev. 3, LA-UR-96-989, Los Alamos National Laboratory, Los Alamos, New Mexico.

Agnew, S. F., 1996b, Hanford Tank Chemical and Radionuclide Inventories: HDW Model, Rev. 3, LA-UR-96-858, Los Alamos National Laboratory, Los Alamos, New Mexico.

Alstad, A. T., 1993, Riser Configuration Document for Single-Shell Waste Tanks, WHC-SD-RE-TI-053, Rev. 9, Westinghouse Hanford Company, Richland, Washington.

Atherton, J. A., 1974, Prediction of Liquor Retention in Saltcakes and Sludges, ARH-CD-230, Atlantic Richfield Hanford Company, Richland, Washington.

Bacon, R. F., 1996, Ferrocyanide Safety Program: Request for Removal of 14 Ferrocyanide Tanks from the Watch List and Resolution of the Ferrocyanide Safery Issue, (letter 9652982 to J. E. Kinzer, DOE-RL, July 3), Westinghouse Hanford Company, Richland, Washington.

Barney, G. S., 1994, The Solubilities of Significant Organic Compounds in HLW Tank Supernatant Solutions, WHC-SA-2565-FP, Westinghouse Hanford Company, Richland, Washington.

Barney, G. S., 1995, The Solubilities of Significant Organic Compounds in HLW Tank Supernatant Solutions - FY 1995 Progress Report, WHC-EP-0988, Westinghouse Hanford Company, Richland, Washington.

Bloom, G. R. and Q. H. Nguyen, 1995, Characterization Data Needs for Development, Design and Operations Retrieval Equipment Development through Data Quality Objective (DQO) Process, WHC-SD-DQO-008, Rev. 0, Westinghouse Hanford Company, Richland, Washington.

Borsheim, G. L., and B. C. Simpson, 1991, An Assessment of the Inventories of Ferrocyanide Watch List Tanks, WHC-SD-WM-EP-133, Rev. 0, Westinghouse Hanford Company, Richland, Washington.

Brevick, C. H., S. F. Agnew, R. A. Corbin, T. B. Duran, K. A. Jurgenson, T. P. Ortiz, B. L. Young, 1995, Waste Status and Transaction Record Summary for the Southwest Quadrant of the Hanford 200 East Area, WHC-SD-WM-TI-614, Rev. 1, Westinghouse Hanford Company, Richland, Washington. 
Brewster, M. E., B. J. Palmer, 1995, Prioritization of Single-Shell Tanks for Study of Gas Retention and Episodic Release, PNL-WTS122295, Pacific Northwest National Laboratory, Richland, Washington.

Brown, T. M., S. J. Eberlein, and T. J. Kunthara, 1995, Tank Waste Characterization Basis, WHC-SD-WM-TA-164, Rev. 1, Westinghouse Hanford Company, Richland, Washington.

Cash, R. J., 1996a, Application of "Flammable Gas Tank Safety Program: Data Requirements for Core Sampling Analysis Developed Through the Data quality Objectives Process, " Rev. 2 (Internal Memo 79300-96-028, to S. J. Eberlein, July 12), Westinghouse Hanford Company, Richland, Washington.

Cash, R. J., 1996b, Scope Increase of "Data quality Objective to Support Resolution of the Organic Complexant Safety Issue, " Rev. 2 (Internal Memo 79300-96-029, to S. J. Eberlein, July 12), Westinghouse Hanford Company, Richland, Washington.

Cash, R. J., 1996c, Scope Increase of "Data Quality Objective to Support Resolution of Organic Complexant Safety Issue," Rev. 2, (Internal Memo 79300-96-032, to S. J. Eberlein, August 1996, Westinghouse Hanford Company, Richland, Washington.

Certa, P. J., C. N. McConville, L. W. Shelton, E. J. Slaathaug, 1996, Preliminary Low-Level Waste Feed Staging Plan, WHC-SD-WM-RPT-210, Rev. 0, Westinghouse Hanford Company, Richland, Washington.

DOE, 1996, Request for Proposals (RFP) No. DE-RPO6-96RL13308 (TWRS Privatization), U.S. Department of Energy, Washington, D. C.

DOE-RL, 1996, Recommendation 93-5 Implementation Plan, DOE-RL 94-0001, Rev. 1, U.S. Department of Energy, Richland Operations Office, Richland, Washington.

Dukelow, G. T., J. W. Hunt, H. Babad, and J. E. Meacham, 1995, Tank Safety Screening Data Quality Objective, WHC-SD-WM-SP-004, Rev. 2, Westinghouse Hanford Company, Richland, Washington.

Eberlein, S. J., 1996, Meeting Minutes of April 26 and 30, 1996 Meetings to Determine TWRS Issue Priorities, (internal memorandum 79000-96-001 to R. F. Bacon, May 20), Westinghouse Hanford Company, Richland, Washington.

Ecology, EPA and DOE, 1996, Hanford Federal Facility Agreement and Consent Order, as amended, Washington State Department of Ecology, Olympia, Washington, U.S. Environmental Protection Agency and U.S. Department of Energy, Washington, D.C. 
EPA, 1994, Guidance For The Data Quality Objectives Process, EPA QA/G-4, U.S. Environmental Protection Agency, Washington, D. C.

Epstein, M., H. K. Fauske, M. D. Crippen, D. R. Dickinson, J. D. McCormack, R. J. Cash, J. E. Meacham, and C. S. Simmons, 1994, Ferrocyanide Safety Program: Assessment of the Possibility of Ferrocyanide Sludge Dryout, WHC-EP-0816, Westinghouse Hanford Company, Richland, Washington.

Fowler, K. D., 1995, Data Quality Objectives for Tank Farms Waste Compatibility Program, WHC-SD-WM-DQO-001, Rev. 1, Westinghouse Hanford Company, Richland, Washington.

Handy, L. L., 1975, Flow Properties of Saltcake for Interstitial Liquid Removal/Immobilization Development Program, ARH-C-6, Atlantic Richfieid Hanford Company, Richland, Washington.

Hanlon, B. M., 1996, Waste Tank Summary Report for Month Ending February 29, 1996, WHC-EP-0182-95, Westinghouse Hanford Company, Richland, Washington.

Hill, J. G., G. S. Anderson, B. C. Simpson, 1995, The Sort on Radioactive Waste Type Model: A Method to Sort Single-Shell Tanks into Characteristic Groups, PNL-9814, Rev. 2, Pacific Northwest National Laboratory, Richland, Washington.

Hodgson, K. M., R. P. Anantatmula, S. A. Barker, K. D. Fowler, J. D. Hopkins, J. A. Lechelt, D. A. Reynolds, D. C. Hedengren, R. E. Stout, R. T. Winward, 1996, Evaluation of Hanford Tanks for Trapped Gas, WHC-SD-WM-ER-526, Rev. 1, Westinghouse Hanford Company, Richland, Washington.

Hopkins, J. D., 1994, Criteria for Flammable Gas Watch List Tanks, WHC-EP-0702, Rev. 0, Westinghouse Hanford Company, Richland, Washington.

Hopkins, J. D., 1996, Methodology for Flammable Gas Evaluations, WHC-SD-WM-TI-724, Rev. 1, Westinghouse Hanford Company, Richland, Washington.

Huckaby, J. L., H. Babad, D. R. Bratzel, 1995, Headspace Gas and Vapor Characterization Summary for the 43 Vapor Program Suspect Tanks, WHC-SD-WM-ER-514, Rev. 1B., UC-2070, Westinghouse Hanford Company, Richland, Washington.

Husa, E. I., D. A. Lauhala, L. A. Tusler, 1995, Hanford Waste Tank Preliminary Dryness Evaluation, WHC-SD-WM-TI-703, Rev. 0, Westinghouse Hanford Company, Richland, Washington.

Kirk, J. J., 1980, Permeability, Porosity, and Capillarity of Hanford Waste Material and Its Limits of Pumpability, RHO-CD-925, Rev. 2, Rockwell Hanford Operations, Richland, Washington. 
Kupfer, M. J., W. W. Schulz, and J. T. Slankas, 1995, Strategy for Sampling Hanford Site Tank Wastes for Development of Disposal Technology, WHC-SD-WM-TA-154, Rev. 1, Westinghouse Hanford Company, Richland, Washington.

Laws, G. L., 1996, Status of the Current Understanding of the Toxic Air Pollutants (TAPS) and Hanford Tank Farm Vapor Space Characterization; Recommended Path Forward and Justification for Continued RMCS Exhauster Operations, (telephone conference memorandum 01830-96-022, to Distribution, March 8), Westinghouse Hanford Company, Richland, Washington.

Lilga, M. A., M. R. Lumetta, and G. F. Schiefelbein, 1993, Ferrocyanide Safety Project, Task 3 Aging Studies, FY 1993 Annual Report, PNL-8888, Pacific Northwest National. Laboratory, Richland, Washington.

Lilga, M. A., E. V. Alderson, M. R. Lumetta, and G. F. Schiefelbein, 1994, Ferrocyanide Safety Project, Task 3: Ferrocyanide Aging Studies, FY 1994 Annual Report, PNL-10126, Pacific Northwest National Laboratory, Richland, Washington.

Lipnicki, J., 1995, Waste Tank Risers Available for Sampling, WHC-SD-WM-TI-710, Rev. 2, Westinghouse Hanford Company, Richland, Washington.

Lumetta, G. J., and B. M. Rapko, 1994, Washing and Alkaline Leaching of Hanford Tank Sludges: A Status Report, PNL-10078, Pacific Northwest National Laboratory, Richland, Washington.

Manuel, A. F., 1996, Phase One High Level Waste Pretreatment and Feed Staging Plan, WHC-SD-WM-ES-370, Rev. 0, Westinghouse Hanford Company, Richland, Washington.

McDuffie, N. G., 1995, Flammable Gas Tank Safety Program: Data Requirements for Core Sample Analysis Developed Through the Data Quality Objectives (DQO) Process, WHC-SD-WM-DQO-004, Rev. 2, Westinghouse Hanford Company, Richland, Washington.

Metz, W. P., 1975, Preliminary Evaluation of the Affects of Capillary Forces on Stabilizing Hanford Waste Saltcakes and Sludges, (internal memorandum to R. J. Thompson, September 9), Atlantic Richfield Hanford Company, Richland, Washington.

Meacham, J. E., H. Babad, R. J. Cash, G. T. Dukelow, S. J. Eberlein, D. W. Hamilton, G. D. Johnson, J. W. Osborne, M. A. Payne, D. J. Sherwood, and D. A. Turner, 1995a, Approach for Tank Safery Characterization of Hanford Site Waste, WHC-EP-0843, Westinghouse Hanford Company, Richland, Washington. 
Meacham, J. E., R. J. Cash, B. A. Pulsipher, and G. Chen, 1995b, Data Requirements for the Ferrocyanide Safety Issue Developed through the Data Quality Objectives Process, WHC-SD-WM-DQO-007, Rev. 1, Westinghouse Hanford Company, Richland, Washington.

Mulkey, C. H., and K. D. Markillie, 1995, Data Quality Objective for Regulatory Requirements for Hazardous and Radioactive Air Emissions Sampling and Analysis, WHC-SD-WM-DQO-021, Rev. 0, Westinghouse Hanford Company, Richland, Washington.

Osborne, J. W., and L. L. Buckley, 1995, Data Quality Objectives for Tank Hazardous Vapor Safety Screening, WHC-SD-WM-DQO-002, Rev. 2, Westinghouse Hanford Company, Richland, Washington.

Powell, W. J., G. R. Bloom, A. J. Brothers, R. G. Brown, J. D. Galbraith, C. E. Jensen, D. E. Place, G. W. Reddick, and W. F. Zuroff, 1996, Neutralized Cladding Removal Waste and Tank 241-SY-102 Waste Management Plan, WHC-SD-WM-RPT-226, Rev. 0, Westinghouse Hanford Company, Richland, Washington.

Price, D. N., 1994, Rotary Core Vapor Sampling Data Quality Objective, WHC-SD-WM-SP-003, Rev. 0, Westinghouse Hanford Company, Richland, Washington.

Rapko, B. M., G. J. Lumetta, and M. J. Wagner, 1995, Washing and Caustic Leaching of Hanford Tank Sludges: Results of FY 1995 Studies, PNL-10712, Pacific Northwest National Laboratory, Richland, Washington.

Recknagle, K. P., 1996, Analysis of Visual Waste Observations for Single Shell Tanks, TWS96.3, Pacific Northwest National Laboratory, Richland, Washington.

Simpson, B. C. and D. J. McCain, 1995, Historical Model Evaluation Data Requirements, WHC-SD-WM-DQO-018, Westinghouse Hanford Company, Richland, Washington.

Slankas, T. J., M. J. Kupfer, and W. W. Schulz, 1995, Data Needs and Attendant Data Quality Objectives for Tank Waste Pretreatment and Disposal, WHC-SD-WM-DQO-022, Rev. 0, Westinghouse Hanford Company, Richland, Washington.

Stanton, G. A., 1996, Baseline Sampling Schedule, Change 96-02, (internal memorandum 75610-96-06, April 17), Westinghouse Hanford Company, Richland, Washington.

Temer, D. J., and R. Villarreal, 1995a, Sludge Washing and Alkaline Leaching Tests on Actual Hanford Tank Sludge: A Draft Report on Samples TY-104 and C-107, LAUR-95-3211, Los Alamos National Laboratory, Los Alamos, New Mexico. 
Temer, D. J., and R. Villarreal, 1995b, Sludge Washing and Alkaline Leaching Tests on Actual Hanford Tank Sludge: A Status Report, LAUR-95-2070, Los Alamos National Laboratory, Los Alamos, New Mexico.

Toffer, H., 1994, Passive Neutron Scans Indicate Potential High Pu, (internal memorandum \#9468 to T. S. Vail, September 30), Westinghouse Hanford Company, Richland, Washington.

Turner, D. A., H. Babad, L. L. Buckley and J. E. Meacham, 1995, Data Quality Objective to Support Resolution of the Organic Complexant Safety Issue, WHC-SD-WM-DQO-006, Rev. 2, Westinghouse Hanford Company, Richland, Washington.

Tusler, L. A., 1995, Double Shell Tanks Plutonium Inventory Assessment, WHC-SD-WM-TI-640, Rev. 0, Westinghouse Hanford Company, Richland, Washington.

Von Bargen, B. H., 1995, 242-A Evaporator/Liquid Effluent Retention Facility Data Quality Objectives, WHC-SD-WM-DQO-014, Rev. 1, Westinghouse Hanford Company, Richland, Washington.

Webb, A. B., J. L. Stewart, D. A. Tumer, M. G. Plys, B. Malinovic, J. M. Grigsby, D. M. Camaioni, P. G. Heasler, W. D. Samuels, J. J. Toth, 1995, Preliminary Safety Criteria for Organic Watch List Tanks at the Hanford Site, WHC-SD-WM-SARR-033, Rev. 0, Westinghouse Hanford Company, Richland, Washington.

WHC, 1994, Operating Specifications for Watch List Tanks, OSD-T-151-00030, Rev. 2B, Westinghouse Hanford Company, Richland, Washington. 
WHC-SD-WM-TA-164 Rev. 2

APPENDIX A

TANK PRIORITY MATRIX

A-1 
WHC-SD-WM-TA-164 Rev. 2

This page intentionally left blank. 


\section{APPENDIX A}

\section{A.0 TANK PRIORITY MATRIX}

Appendix A describes the priority matrix. The priority matrix refers to a spreadsheet that was used to determine the priorities of all single-shell and double-shell tanks for sampling. Input to the priority matrix is provided using the issue criteria outlined in this report. The results of the priority matrix are given in Appendices B through F. To facilitate understanding of the matrix, tank $241-\mathrm{SX}-101$ is provided as an example.

\section{A.1 TANKS IN SCOPE OF ISSUES}

Appendix B outlines which tanks are in the scope of each issue defined in the technical basis report. All tanks are listed in Appendix B in alphabetical order, starting with single-shell tanks and followed by double-shell tanks. All issues discussed in Section 3.1 are shown in the columns of the table. An " $\mathrm{X}$ " indicates that the tank is within the scope of the issue. A blank indicates that the tank is out of scope of the issue. Ferrocyanide is not included in the table because no more sampling will be performed for the ferrocyanide issue at this time.

For example, Appendix B indicates that tank 241-SX-101 is within the scope of the safety screening, vapor screening, process testing/sludge washing, and the historical model evaluation issues.

\section{A.2 ISSUE PRIORITY LISTS}

Appendicies $\mathrm{Cl}$ through $\mathrm{C} 9$ provides a priority matrix for each specific issue. The issues are:

- Flammable Gas - Appendix C1

- Organic Phenomenology - Appendix C2

- Safety Screening - Appendix C3

- Vapor Screening - Appendix C4

- Vapor Phenomenology - Appendix C5

- Privatization - Appendix C6

- Process Testing/Sludge Washing - Appendix C7-1

- Process Testing/Supernatant Pretreatment - Appendix C7-2

- Retrieval - Appendix C8

- Historical Model Evaluation - Appendix C9 
For each TWRS program issue, a separate spreadsheet has been created to facilitate the generation of an issue priority list. The first step in creating issue-specific priority lists is to determine what criteria influence the selection of tanks for sampling (for each particular issue). For example, the criteria that influence tank selection for the safety screening issue are energetics, criticality (total plutonium content), non-characterized waste type, dryness, and vapor flammability. Criteria are documented for each issue in Section 4.0.

The second step in creating issue-specific priority lists is to rank the priority of each criterion against one another. This step is accomplished by assigning each criterion a priority of high, medium, or low. For ranking criterion, high priority is assigned a value of 5 , medium priority is assigned a value of 3 , and low priority is assigned a value of 1 (see Appendices $\mathrm{C} 1$ through $\mathrm{C9}$ ). For the safety screening issue, energetics are high priority, plutonium content and non-characterized waste type are medium priority, and dryness and vapor flammability are low priority (for example, a tank that is expected to have high quantities of exothermic constituents is a higher priority than a tank with dry waste). The priorities of each criteria are documented in Section 4.0 .

The third step in creating issue-specific priority lists is to determine the priority of each tank with respect to each separate criterion. This is accomplished by defining the bounds for high, medium, and low priority for each criterion. These priority ratings are entered into the spreadsheet for each tank for each criterion (see Appendices C1 through C9). For the safety screening criterion of energetics, tanks predicted to have over 1 weight percent TOC, medium priority for tanks between 0.4 and 1 weight percent TOC, and low for tanks with less than 0.4 weight percent TOC (see Section 5.3 WHC-SD-WM-TA-164, Rev. 2 for definition of priority rating). Based on each criterion, tanks with a high priority are assigned an arbitrary value of 5, medium priority tanks are assigned a value of 3 , and low priority tanks receive a value of 0 . After each tank is assigned a priority for each criterion, the tanks are assigned a weighted priority value for each criterion. This weighted priority value is calculated for each tank by multiplying the tank priority $(0,3$, or 5$)$ by the criterion priority $(1,3$, or 5$)$.

The final step in creating the issue-specific priority lists is to sum up the weighted priority values for each tank for each separate criterion. This sum represents the relative priority for each tank within the scope of the issue. These numbers are normalized so that the least important tank within the scope of the issue received a priority ranking of 0 and the most important tank within the scope of the issue received a priority ranking of 100 (see Appendices C1 through C9).

Tank 241-SX-101 is high priority for the criteria of non-characterized waste type, dryness, and vapor flammability, and medium priority for the criterion of energetics and plutonium. The total priority ranking for tank $241-\mathrm{SX}-101$ for safety screening is calculated as follows:

Total Priority $=\quad$ (tank priority for waste type)*(criterion priority for waste type) + (tank priority for dryness)*(criterion priority for dryness) + (tank priority for energetics)*(criterion priority for energetics) + (tank 
priority for plutonium)*(criterion priority for plutonium) + (tank

priority for flammability)*(criterion priority for flammability)

Total Priority $=(5 * 3)+(5 * 1)+(3 * 5)+(3 * 3)+(5 * 1)=49$

After the total priority values for each tank within the scope of the issue are calculated, the values are normalized so that the tank with the lowest total priority number receives a normalized value of 0 and the tank with the highest total priority number received a normalized value of 100 . All other tanks receive numbers between 0 and 100 , depending upon their relative importance to the rest of the tanks in scope of the issue.

After normalizing the total safety screening priority for tank 241-SX-101 with the total priority for all other tanks, the normalized priority for tank 241-SX-101 for safety screening is 89 (out of 100).

\section{A.3 MULTI ISSUE PRIORITY LIST}

In Appendix D, each issue priority list has been collected in one table. Appendix D is a quick reference for priority scores for all issues. Each row represents an issue. Each column represents a tank. Tanks that are not within the scope of an issue are shown as n/a.

Tank 241-SX-101 has a safety screening priority of 89 (see Section A.2), a vapor screening priority of 0 , a sludge washing priority of 94 , and a historical model evaluation priority of 100. All other issues are not in scope. Although tank 241-SX-101 has a priority of 0 for vapor screening, it is still in scope of the issue.

\section{A.4 COMBINED ISSUE PRIORITY LIST}

Appendix E provides combined issue priority lists for solid, liquid, and vapor phase sampling. Individual issue priority lists are combined using the issue weights developed in Section 5.0. The issue weights are referred to as "width" in the matrix (see Appendix E). The width number has a multiplicative effect on the weight of the separate issue priority numbers for each tank.

One other number is used in the matrix and is referred to as the "shift." The shift is used only for issues that do not have all 177 tanks within the scope of the issue. Shift represents the importance of the least important tank within an issue compared to the most important tank within an issue. The shift for flammable gas is 0.1 and the width is 10 . These figures mean that the lowest priority flammable gas tank is 10 percent as important as the highest priority 
flammable gas tank. For issues that have all 177 tanks within their scope, a shift of 0 is used. Safety screening and vapor screening are the only issues with all tanks within the scope of the issue.

Once the width and shift values are entered into the matrix, the spreadsheet calculates a new priority value for each tank for each issue. The original (normalized) priority value for each tank is multiplied by the width number, then added to the shift number. The result of this manipulation is that every tank has a number that represents its importance to each issue further weighted by the importance of the issue. Hence, tanks that are high priority for an important issue are given much more overall priority than are tanks that are high priority for a low-priority issue.

Finally, the priority numbers for each issue are summed together for each tank. This final sum represents the overall priority for each tank with all issues considered. These numbers are normalized so that the lowest priority tank has a priority of 0 and the most important tank has a priority of 100 . The tanks that are at the top of the priority list are those that are important to several issues. Note that the final manipulation was performed separately for solid, liquid, and vapor phases. This was done to ensure that, for example, an issue that requires information in the vapor phase does not affect the priority number for solid sampling.

At the bottom of each page in Appendix E, a combined priority list is provided for solid, liquid, and vapor phases. Tank 241-SX-101 has a solids priority of 48 (out of 100) and a liquid and vapor priority of 0 each. This indicates that solid sampling of tank 241-SX-101 is almost one half as important as the solid sampling of tank 241-U-103 which has a solid priority of 100 . Tank 241-SX-101 has low priority for liquid or vapor phase sampling.

\section{A.5 CONSTRANTS}

Appendix F lists technical constraints to sampling. Many possible constraints to sampling are listed even though only 3 constraints are active: previously sampled tanks, number of risers available, and low volume tanks. The constraints section of the matrix has the effect of constraining a tank from sampling that meets the constraints criteria outlined in Section 6.2.

Appendix F indicates that tank 241-SX-101 was not constrained from sampling. 
WHC-SD-WM-TA-164 Rev. 2

APPENDIX B

TANKS IN SCOPE OF ISSUES

B-1 
WHC-SD-WM-TA-164 Rev. 2

This page intentionally left blank. 
WHC-SD-WM-TA-164 Rev 2

TANKS IN SCOPE OF ISSUES

\begin{tabular}{|c|c|c|c|c|c|c|c|c|c|c|}
\hline \multirow[b]{2}{*}{ TANK } & \multirow[b]{2}{*}{$\begin{array}{c}\text { Flammable } \\
\text { Gas }\end{array}$} & \multirow[b]{2}{*}{$\begin{array}{c}\text { Organic } \\
\text { Phenomenology }\end{array}$} & \multirow[b]{2}{*}{$\begin{array}{c}\text { Safety } \\
\text { Screening }\end{array}$} & \multicolumn{3}{|c|}{ APPLICABLE DQOs } & \multirow[b]{2}{*}{$\begin{array}{l}\text { Process } \\
\text { Testing- } \\
\text { Sludge }\end{array}$} & \multirow[b]{2}{*}{$\begin{array}{c}\text { Process } \\
\text { Testing- } \\
\text { Supernatant }\end{array}$} & \multirow[b]{2}{*}{ Retrievel } & \multirow[b]{2}{*}{$\begin{array}{c}\text { Historical } \\
\text { Model } \\
\text { Evaluation }\end{array}$} \\
\hline & & & & $\begin{array}{c}\text { Vapor } \\
\text { Screening }\end{array}$ & $\begin{array}{c}\text { Vapor } \\
\text { Phenomenology } \\
(93-5)\end{array}$ & Privatization & & & & \\
\hline A-101 & $x$ & $x$ & $x$ & $x$ & & & $x$ & & & $x$ \\
\hline A-102 & & $x$ & $x$ & $\underline{x}$ & & & & & & \\
\hline A-103 & $x$ & & $x$ & $x$ & & & & & & $x$ \\
\hline A-104 & & & $x$ & $x$ & & & & & & \\
\hline A-105 & & & $\bar{x}$ & $x$ & & & & & & \\
\hline A-106 & & & $x$ & $x$ & & & & & & $x$ \\
\hline AX-101 & & $x$ & $x$ & $x$ & & & & & & $x$ \\
\hline$A \times-102$ & & $x$ & $x$ & $x$ & & & & & & \\
\hline AX-103 & & & $x$ & $x$ & & & & & $x$ & $x$ \\
\hline AX-104 & & & $x$ & $x$ & & & & & $x$ & \\
\hline B-101 & & & $x$ & $x$ & & & & & & \\
\hline B-102 & & $\bar{x}$ & $x$ & $x$ & & & & & & \\
\hline B-103 & & $x$ & $x$ & $x$ & $x$ & & $x$ & & & \\
\hline B-104 & & & $x$ & $x$ & & & $x$ & & & $x$ \\
\hline B-105 & & & $x$ & $x$ & & & & & & $x$ \\
\hline B-106 & & & $x$ & $x$ & & & $x$ & & & $x$ \\
\hline B-107 & & & $x$ & $x$ & & & & & & \\
\hline B-108 & & & $x$ & $x$ & & & & & & $x$ \\
\hline B-109 & & & $x$ & $x$ & & & & & & \\
\hline B-110 & & & $x$ & $x$ & & & $x$ & & & \\
\hline B-111 & & & $x$ & $x$ & & & $x$ & & & \\
\hline B-112 & & & $x$ & $x$ & & & & & & \\
\hline B-201 & & & $x$ & $x$ & & & $x$ & & & \\
\hline B-202 & & & $x$ & $x$ & & & $x$ & & & \\
\hline B-203 & & & $x$ & $x$ & & & & & & \\
\hline B-204 & & & $x$ & $x$ & & & & & & \\
\hline BX-101 & & & $x$ & $x$ & & & & & & \\
\hline BX-102 & & & $x$ & $x$ & & & & & & \\
\hline$B X-103$ & & & $x$ & $x$ & & & $x$ & & & \\
\hline BX-104 & & & $x$ & $x$ & $x$ & & & & & \\
\hline BX-105 & & $x$ & $x$ & $x$ & & & $x$ & & & \\
\hline BX-106 & & & $x$ & $x$ & & & & & & \\
\hline BX-107 & & & $x$ & $x$ & & & $x$ & & & \\
\hline BX-108 & & & $x$ & $x$ & & & & & & \\
\hline BX-109 & & & $x$ & $x$ & & & $x$ & & & $x$ \\
\hline BX-110 & & $x$ & $x$ & $x$ & & & $x$ & & & $x$ \\
\hline
\end{tabular}


WHC-SD-WM-TA-164 Rev 2

TANKS IN SCOPE OF ISSUES

\section{APPLICABLE DQOs}

TANK Flammable $\begin{array}{cc}\text { Organic Safety } \\ \text { Phenomenology Screening }\end{array}$

Vapor

Gas Phenomenology Screening Screening Phenomenology

$$
\text { (93-5) }
$$

Privatization

\begin{tabular}{|c|c|c|}
\hline $\begin{array}{l}\text { Process } \\
\text { Testing- } \\
\text { Sludge }\end{array}$ & $\begin{array}{l}\text { Process } \\
\text { Testing- } \\
\text { Supernatant }\end{array}$ & Retrievel \\
\hline
\end{tabular}

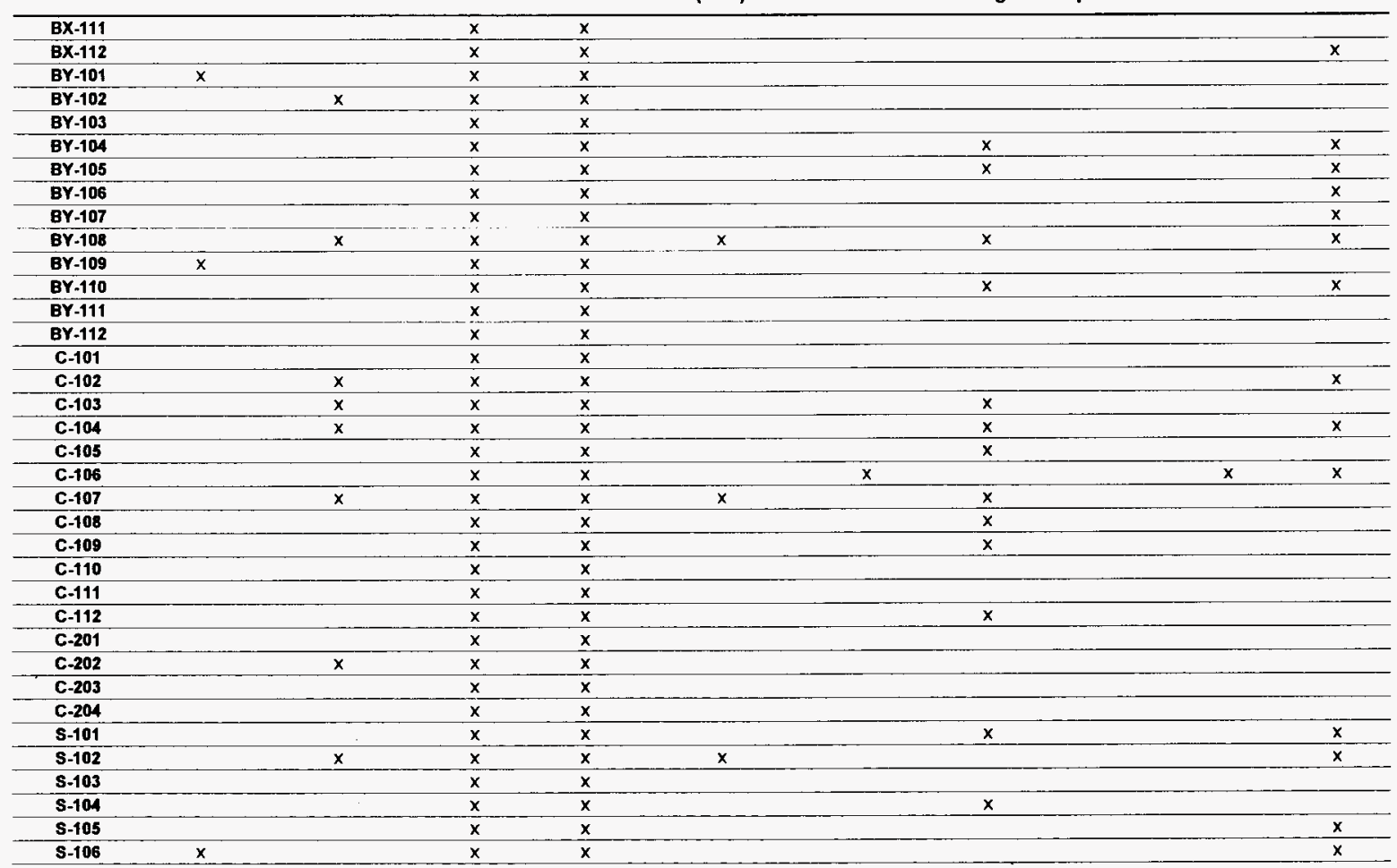


WHC-SD-WM-TA-164 Rev 2

TANKS IN SCOPE OF ISSUES

\begin{tabular}{|c|c|c|c|c|c|c|c|c|c|c|}
\hline \multirow[b]{2}{*}{ TANK } & \multirow[b]{2}{*}{$\begin{array}{c}\text { Flammable } \\
\text { Gas }\end{array}$} & \multirow[b]{2}{*}{$\begin{array}{c}\text { Organic } \\
\text { Phenomenology }\end{array}$} & \multirow[b]{2}{*}{$\begin{array}{c}\text { Safety } \\
\text { Screening }\end{array}$} & \multicolumn{3}{|c|}{ APPLICABLE DQOs } & \multirow[b]{2}{*}{$\begin{array}{c}\text { Process } \\
\text { Testing- } \\
\text { Sludge }\end{array}$} & \multirow[b]{2}{*}{$\begin{array}{c}\text { Process } \\
\text { Testing- } \\
\text { Supernatant }\end{array}$} & \multirow[b]{2}{*}{ Retrievel } & \multirow[b]{2}{*}{$\begin{array}{l}\text { Historical } \\
\text { Model } \\
\text { Evaluation }\end{array}$} \\
\hline & & & & $\begin{array}{c}\text { Vapor } \\
\text { Screening }\end{array}$ & $\begin{array}{c}\text { Vapor } \\
\text { Phenomenology } \\
(93-5)\end{array}$ & Privatization & & & & \\
\hline S-107 & & & $x$ & $x$ & & & $x$ & & & $x$ \\
\hline S-108 & & & $\bar{x}$ & $x$ & & & & & & $x$ \\
\hline s-109 & & & $x$ & $x$ & & & & & & $x$ \\
\hline $5-110$ & & & $x$ & $x$ & & & $x$ & & & $x$ \\
\hline s-111 & & $x$ & $x$ & $x$ & & & & & & $x$ \\
\hline S- -112 & $x$ & & $x$ & $x$ & & & & & & \\
\hline SX-101 & & & $x$ & $x$ & & & $x$ & & & $x$ \\
\hline sx-102 & & & $x$ & $x$ & & & & & & $x$ \\
\hline $5 x-103$ & & $x$ & $x$ & $x$ & & & & & & $x$ \\
\hline sx-104 & & & $x$ & $x$ & & & $x$ & & & $x$ \\
\hline sx-105 & & & $x$ & $x$ & & & & & & $x$ \\
\hline SX-106 & $x$ & $x$ & $x$ & $x$ & & & & & & \\
\hline SX-107 & & & $x$ & $x$ & & & $x$ & & & \\
\hline SX-108 & & & $x$ & $x$ & & & $x$ & & & $x$ \\
\hline sx-109 & & & $x$ & $x$ & & & $x$ & & & \\
\hline$s x-110$ & & & $x$ & $x$ & & & $x$ & & & \\
\hline sx-111 & & & $x$ & $x$ & & & & & & \\
\hline sx-112 & & & $x$ & $x$ & & & & & & \\
\hline sx-113 & & & $x$ & $x$ & & & $x$ & & & \\
\hline sx-114 & & & $x$ & $x$ & & & & & & \\
\hline SX-115 & & & $x$ & $x$ & & & & & & \\
\hline T-101 & & & $x$ & $x$ & & & & & & \\
\hline $\mathrm{T}-102$ & & & $x$ & $x$ & & & & & & \\
\hline $\mathrm{T}-103$ & & & $x$ & $x$ & & & $x$ & & & \\
\hline T-104 & & & $x$ & $x$ & & & $x$ & & & \\
\hline $\mathrm{T}-105$ & & & $x$ & $x$ & & & & & & \\
\hline$T-106$ & & & $x$ & $x$ & & & & & & \\
\hline$T-107$ & & & $x$ & $x$ & & & $x$ & & & \\
\hline$T-108$ & & & $x$ & $x$ & & & & & & $x$ \\
\hline$T-109$ & & & $x$ & $x$ & & & & & & $x$ \\
\hline T-110 & & & $x$ & $x$ & & & & & & \\
\hline$T-111$ & & $x$ & $x$ & $x$ & & & & & & \\
\hline T-112 & & & $x$ & $x$ & & & $x$ & & & \\
\hline$T-201$ & & & $x$ & $x$ & & & $x$ & & & \\
\hline$T-202$ & & & $x$ & $x$ & & & & & & \\
\hline T-203 & & & $x$ & $x$ & & & & & & \\
\hline
\end{tabular}


WHC-SD-WM-TA-164 Rev 2

TANKS IN SCOPE OF ISSUES

APPLICABLE DQOS

TANK Flammable Organic Safety Vapor Vapor Privatization Process Process Retrievel Historical Gas Phenomenology Screening Screening Phenomenology

(93-5)

\section{Process}

Sludge

Supernatant

Model

Evaluation

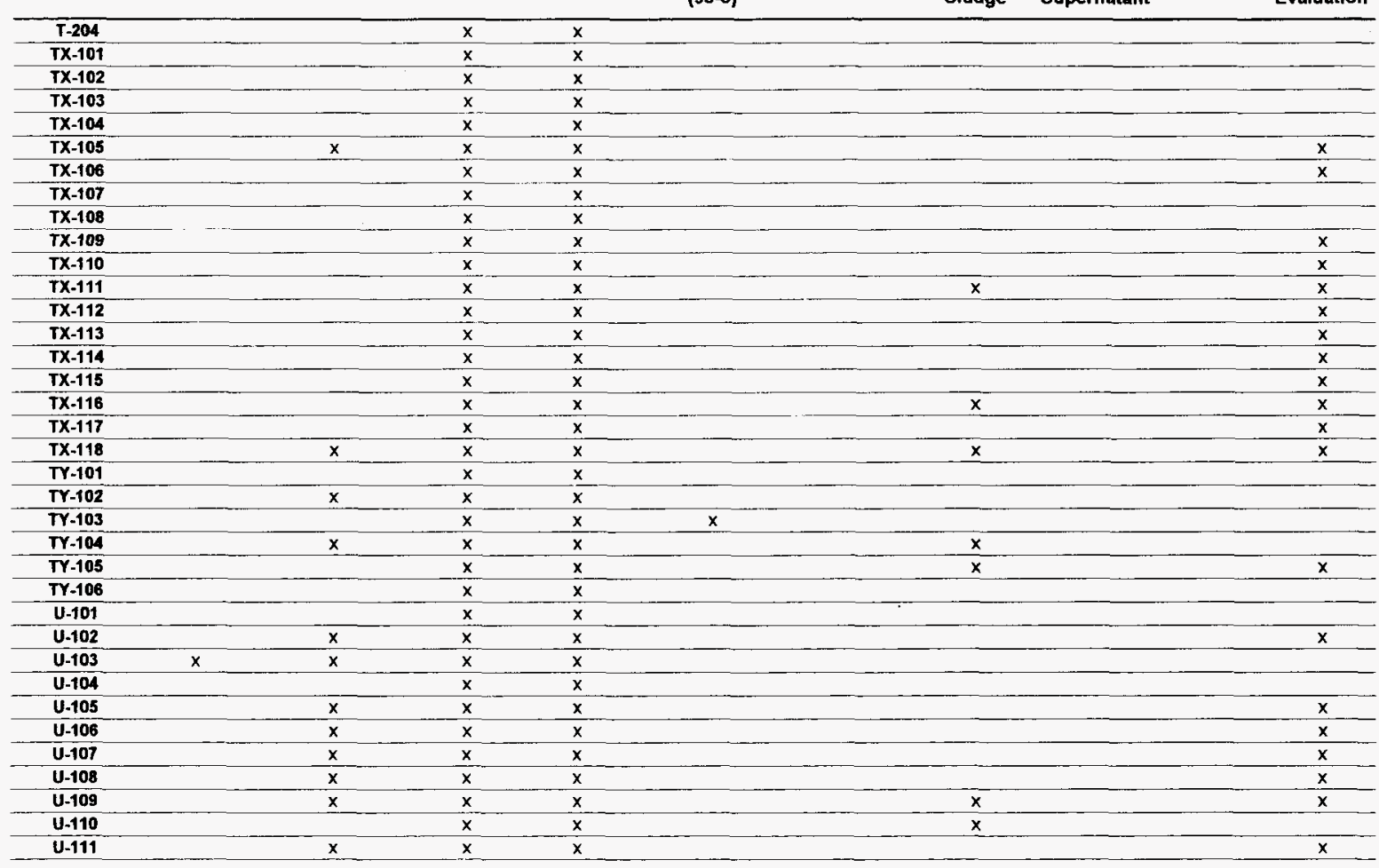


WHC-SD-WM-TA-164 Rev 2

TANKS IN SCOPE OF ISSUES

\begin{tabular}{|c|c|c|c|c|c|c|c|c|c|c|}
\hline \multirow[b]{2}{*}{ TANK } & \multirow[b]{2}{*}{$\begin{array}{c}\text { Flammable } \\
\text { Gas }\end{array}$} & \multirow[b]{2}{*}{$\begin{array}{c}\text { Organic } \\
\text { Phenomenology }\end{array}$} & \multirow[b]{2}{*}{$\begin{array}{c}\text { Safety } \\
\text { Screening }\end{array}$} & \multicolumn{2}{|c|}{ APPLICABLE DQOs } & \multirow[b]{2}{*}{ Privatization } & \multirow[b]{2}{*}{$\begin{array}{l}\text { Process } \\
\text { Testing- } \\
\text { Sludge }\end{array}$} & \multirow[b]{2}{*}{$\begin{array}{c}\text { Process } \\
\text { Testing- } \\
\text { Supernatant }\end{array}$} & \multirow[b]{2}{*}{ Retrievel } & \multirow[b]{2}{*}{$\begin{array}{l}\text { Historical } \\
\text { Model } \\
\text { Evaluation }\end{array}$} \\
\hline & & & & $\begin{array}{c}\text { Vapor } \\
\text { Screening }\end{array}$ & $\begin{array}{c}\text { Vapor } \\
\text { Phenomenology } \\
(93-5)\end{array}$ & & & & & \\
\hline U-112 & & & $x$ & $x$ & $x$ & & & & & \\
\hline U-201 & & & $x$ & $x$ & & & & & & \\
\hline U-202 & & & $\bar{x}$ & $x$ & & & & & & \\
\hline U-203 & & $x$ & $x$ & $x$ & & & & & & \\
\hline U-204 & & $x$ & $x$ & $x$ & & & & & & \\
\hline AN-101 & & & $x$ & $x$ & & $x$ & & & & \\
\hline AN-102 & & & $x$ & $x$ & & $x$ & & $x$ & & \\
\hline AN-103 & $x$ & & $x$ & $x$ & & $x$ & & & & \\
\hline AN-104 & $x$ & & $x$ & $x$ & & $x$ & & $x$ & & \\
\hline AN-105 & $x$ & & $x$ & $x$ & & $x$ & & $\bar{x}$ & & \\
\hline AN-106 & & & $x$ & $x$ & & $x$ & & $x$ & & \\
\hline AN-107 & $x$ & & $x$ & $\mathbf{x}$ & & $x$ & & $x$ & & \\
\hline AP-101 & & & $x$ & $x$ & & $x$ & & $x$ & & \\
\hline AP-102 & & & $\bar{x}$ & $x$ & & $x$ & & & & \\
\hline AP-103 & & & $x$ & $x$ & & $x$ & & & & \\
\hline AP-104 & & & $x$ & $x$ & & $x$ & & & & \\
\hline AP-105 & & & $x$ & $\mathbf{x}$ & & $x$ & & $x$ & & \\
\hline AP-106 & & & $x$ & $x$ & & $\bar{x}$ & & & & \\
\hline AP-107 & & & $x$ & $x$ & & $x$ & & & & \\
\hline AP.108 & & & $x$ & $x$ & & $x$ & & & & \\
\hline$A W-101$ & $x$ & & $x$ & $x$ & & $x$ & & $x$ & & \\
\hline AW-102 & & & $x$ & $x$ & & $x$ & & & & \\
\hline AW-103 & & & $x$ & $x$ & & $x$ & & $x$ & & \\
\hline$A W-104$ & $x$ & & $x$ & $x$ & & $x$ & & & & \\
\hline AW-105 & & & $x$ & $x$ & & $x$ & & $x$ & & \\
\hline AW-106 & & & $x$ & $x$ & & $x$ & & & & \\
\hline AY-101 & $x$ & & $x$ & $\underline{x}$ & & $x$ & & & & \\
\hline AY-102 & & & $\bar{x}$ & $x$ & & $x$ & & & $x$ & \\
\hline$A Z-101$ & & & $x$ & $x$ & & $x$ & & $x$ & $x$ & \\
\hline AZ-102 & & & $x$ & $x$ & & $x$ & & $x$ & & \\
\hline SY-101 & $x$ & & $x$ & $x$ & & $x$ & & & & \\
\hline SY-102 & & & $x$ & $x$ & & $x$ & & & & \\
\hline SY-103 & $x$ & & $x$ & $x$ & & $x$ & & & & \\
\hline
\end{tabular}


WHC-SD-WM-TA-164 Rev. 2

This page intentionally left blank. 
WHC-SD-WM-TA-164 Rev. 2

APPENDIX C

ISSUES

C-1 
WHC-SD-WM-TA-164 Rev. 2

This page intentionally left blank. 
WHC-SD-WM-TA-164 Rev, 2

APPENDIX C1

FLAMMABLE GAS

C1-1 
WHC-SD-WM-TA-164 Rev. 2

This page intentionally left blank. 
WHC-SD-WM-TA-164 Rev 2

\section{FLAMMABLE GAS}

CRITERIA
Gas retention
Waste type

Waste type

RGS ability

Episodic release

WEIGHT

\section{NUMERICAL ASSIGNMENTS}

\begin{tabular}{|c|c|c|c|c|c|}
\hline & & & & & \\
\hline & & $A-101$ & A-103 & BY-101 & $B Y-109$ \\
\hline Gas retention & 5 & 25 & 0 & 0 & 0 \\
\hline Waste type & 3 & 15 & 9 & 15 & 9 \\
\hline RGS ability & 5 & 25 & 25 & 25 & 25 \\
\hline Episodic release & 5 & 0 & 0 & 0 & 0 \\
\hline Total & & 65 & 34 & 40 & 34 \\
\hline Relative total (\%) & & 87 & 45 & 53 & 45 \\
\hline CRITERIA & WEIGHT & AW-104 & AY-101 & SY-101 & SY-103 \\
\hline Gas retention & H & $M$ & $\mathbf{L}$ & H & $L$ \\
\hline Waste type & $M$ & & & & \\
\hline RGS ability & H & $\mathrm{H}$ & $\mathrm{H}$ & $\mathrm{H}$ & $H$ \\
\hline Episodic release & H & & & $\mathrm{H}$ & $\mathrm{H}$ \\
\hline \multicolumn{6}{|c|}{ NUMERICAL ASSIGNMENTS } \\
\hline & & $A W-104$ & AY-101 & SY-101 & SY-103 \\
\hline Gas retention & 5 & 15 & 0 & 25 & 0 \\
\hline Waste type & 3 & 0 & 0 & 0 & 0 \\
\hline RGS ability & 5 & 25 & 25 & 25 & 25 \\
\hline Episodic rolease & 5 & 0 & 0 & 25 & 25 \\
\hline Total & & 40 & 25 & 75 & 50 \\
\hline Relative total (\%) & & 53 & 33 & 100 & 67 \\
\hline
\end{tabular}


WHC-SD-WM-TA-164 Rev. 2

This page intentionally left blank. 
WHC-SD-WM-TA-164 Rev. 2

APPENDIX C2

\section{ORGANIC PHENOMENOLOGY}

C2-1 
WHC-SD-WM-TA-164 Rev. 2

This page intentionally left blank. 
WHC-SD-WM-TA-164 Rev 2

CRITERIA

Unsafe if liquid drained

Unsafe if drained and dried out

Organic watch list

HDW model evaluation

\section{ORGANIC PHENOMENOLOGY}

\section{NUMERICAL ASSIGNMENTS}

Unsafe if liquid drained

Unsafe if drained and dried out

Organic watch list

HDW model evaluation

$\begin{array}{cc}\text { WEIGHT } & \text { A-101 } \\ H & \\ M & \\ L & H \\ H & \end{array}$

A-102 AX-101 AX-102

B-102

B-103

BX-105

BX-110

BY-102

BY-108

C-102

$H$

H

$\mathrm{H}$

H

Total

Relative total (\%)

A-10

$\begin{array}{ccc}A-101 & \text { A-102 } & \text { AX- } \\ 0 & 25 & 0 \\ 0 & 0 & 0 \\ 5 & 0 & 0 \\ 0 & 0 & 25\end{array}$

$5 \quad 25$

25
80

AX-101 AX
0
0
0
25

-102
0
0
5
0

B-102

B-103

$B X-105 \quad B X-110$

BY-102 BY-108

000

$\begin{array}{cc}0 & 25 \\ 15 & 0\end{array}$

15

0

25
0
0

$\begin{array}{cc}0 & 0 \\ 15 & 0 \\ 0 & 5 \\ 0 & 0\end{array}$

25
80

5
0

15
40

15

25

25

15

5

\section{CRITERIA}

Unsafe if liquid drained

Unsafe if drained and dried out

Organic watch list

HDW model evaluation

WEIGHT
H
M
L
$H$

C-103

C-104

C-107

$\mathrm{C}-202$

S-102

S-111

sX-103

$S x-106$

$\mathrm{T}-111$

TX-105

$\mathrm{TX}-118$

H

\section{NUMERICAL ASSIGNMENTS}

Unsafe if liquid drained

Unsafe if drained and dried out

Organic watch list

HDW model ovaluation

Total

Relative total (\%)

5
3
1
5

c-

$\begin{array}{ccc}-103 & C-104 & C-107 \\ 0 & 0 & 0 \\ 0 & 0 & 0 \\ 5 & 0 & 0 \\ 0 & 25 & 25 \\ & & \\ 5 & 25 & 25 \\ 0 & 80 & 80\end{array}$

$C-202$
0
0
0
25

25
80

$5-10$
0
0
5
0
5
0

S-111

$s \times-103$

sX-1

$\begin{array}{ccc}\text { T-111 } & \text { TX-105 } & \text { TX-118 } \\ 0 & 0 & 0 \\ 0 & 0 & 0 \\ 5 & 5 & 5 \\ 0 & 0 & 0\end{array}$

30

5

5 


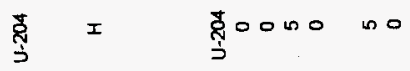

$$
\begin{aligned}
& \text { 空 I } \\
& \text { I I } \sum_{j} 0000 \text { wo } \\
& \frac{8}{3}=\quad \frac{8}{5} \times 00028 \\
& \frac{8}{3} x \quad \frac{8}{3} \times 000 \quad 28
\end{aligned}
$$

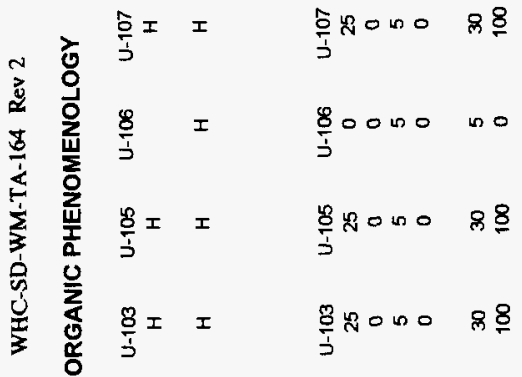

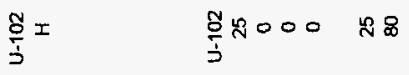

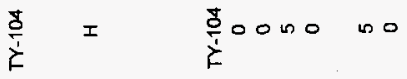

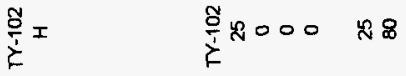

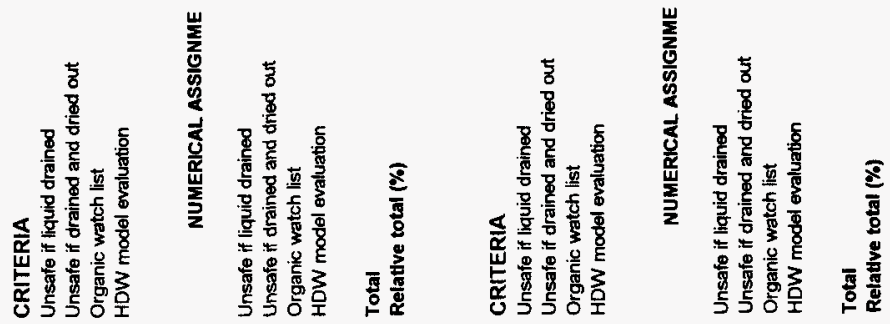


WHC-SD-WM-TA-164 Rev. 2

APPENDIX C3

SAFETY SCREENING

C3-1 
WHC-SD-WM-TA-164 Rev. 2

This page intentionally left blank. 


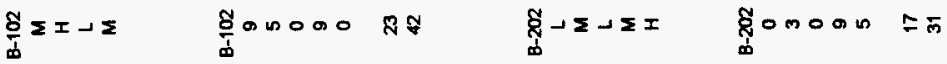

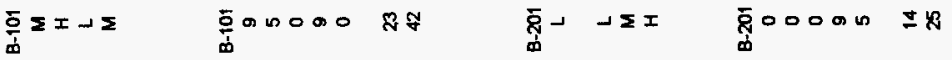

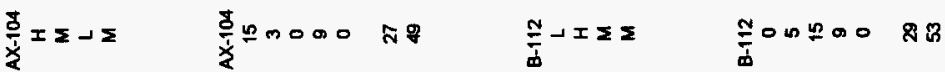

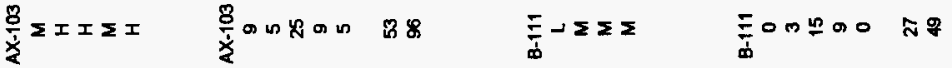

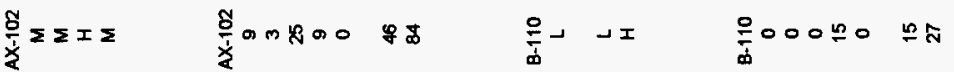

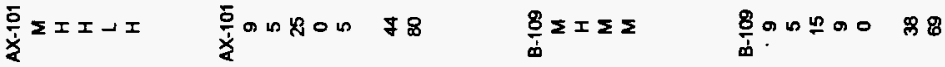

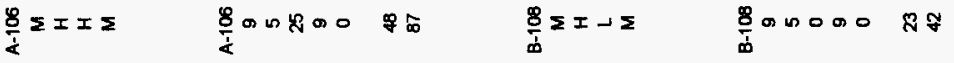

$$
\begin{aligned}
& \text { 旁 }
\end{aligned}
$$

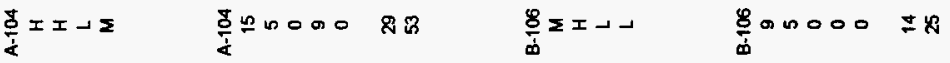

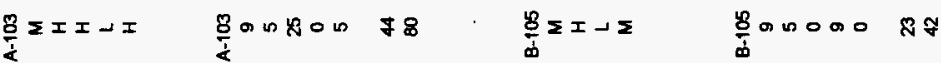

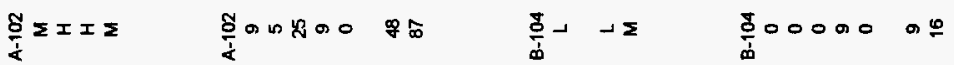

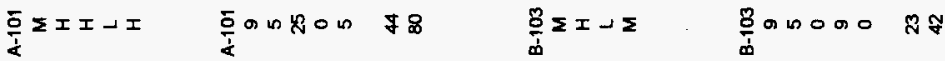

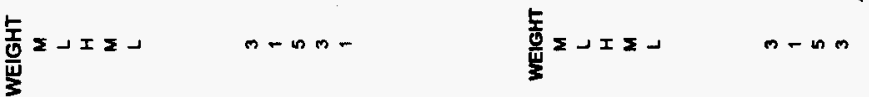

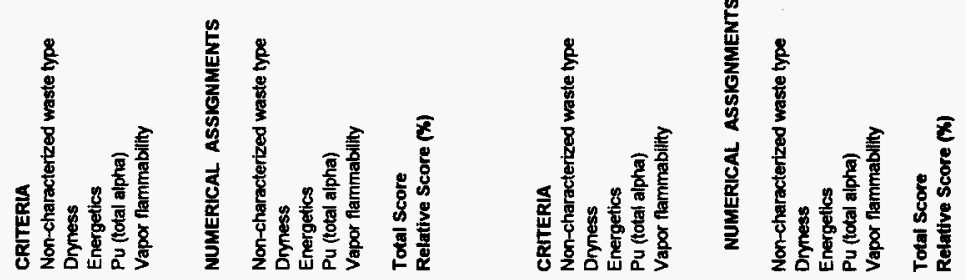


WHC-SD-WM-TA-164 Rev 2

SAFETY SCREENING

\section{CRITERIA}

Non-characterized waste type

\section{Dryness}

Energetics

Pu (total alpha)

Vapor flammability

NUMERICAL ASSIGNMENTS

Non-characterized waste type

\section{Dryness}

Energetics

Pu (total alpha)

Vapor flammability

Total Score

Relative Score ( $\%$ )

\section{CRITERIA}

Non-characterized waste type

Dryness

Energetics

Pu (total alpha)

Vapor flammability

\section{NUMERICAL ASSIGNMENTS}

Non-characterized waste type

Dryness

Energetics

Pu (total alpha)

Vapor flammability

Total Score

Relative Score (x)

$\begin{array}{cc}\text { B-203 } & B-204 \\ L & L \\ M & M \\ L & L \\ M & M\end{array}$

BX-101

$L$
$M$
$M$
$M$

$B X-102$
$L$
$H$
$L$
$M$

BX-103

BX-104

BX-105

$\begin{array}{cccccc}\text { BX-106 } & \text { BX-107 } & \text { BX-100 } & \text { BX-109 } & \text { BX-110 } & \text { BX-111 } \\ M & L & L & L & L & H \\ M & L & H & & M & H \\ M & \text { H } & \text { H } & \text { M } & M & M \\ & H & & & & M\end{array}$

$\begin{array}{ccccc}\text { B-203 } & \text { B-204 } & \text { BX-101 } & \text { BX-102 } & \text { BX-103 } \\ 0 & 0 & 0 & 0 & 0 \\ 3 & 3 & 3 & 5 & 0 \\ 0 & 0 & 15 & 0 & 15 \\ 9 & 9 & 9 & 9 & 9 \\ 0 & 0 & 0 & 0 & 0 \\ 12 & 12 & 27 & 14 & 24 \\ 22 & 22 & 49 & 25 & 44\end{array}$

BX-104

BX-105

$B X-106 \quad B X-107$

$\begin{array}{cccc}B X-108 & B X-109 & B X-110 & B X-111 \\ 0 & 0 & 0 & 15 \\ 5 & 0 & 3 & 5 \\ 0 & 0 & 15 & 15 \\ 15 & 9 & 9 & 9 \\ 0 & 0 & 0 & 0 \\ 20 & 9 & 27 & 44 \\ 36 & 16 & 49 & 80\end{array}$

BX-112

BY-101

BY-102

$\begin{array}{cc}\text { Y-102 } & \text { BY-103 } \\ H & H \\ M & M \\ M & M \\ M & L \\ H & H\end{array}$

BY-104

$\begin{array}{cc}H \\ H \\ M & \\ M & \end{array}$

BY-105
$H$
$H$
$M$
$M$
$H$

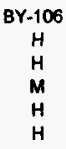

BY-107
$H$
$H$
$M$
$M$

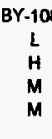

BY-10
$H$
$M$
$M$
$M$
$M$

BY-110

BY-111 BY-112

$\begin{array}{ccc}H & H & H \\ H & H & H \\ M & M & M \\ M & M & L\end{array}$

BX

$\begin{array}{cccc}\text { BX-112 } & \text { BY-101 } & \text { BY-102 } & \text { BY-103 } \\ 0 & 15 & 15 & 15 \\ 0 & 5 & 3 & 3 \\ 25 & 15 & 15 & 15 \\ 9 & 9 & 9 & 0 \\ 0 & 5 & 5 & 5 \\ & & & \\ 34 & 49 & 47 & 38 \\ 62 & 89 & 85 & 69\end{array}$

$\begin{array}{cc}\text { BY-104 } & \text { BY-105 } \\ 15 & 15 \\ 5 & 5 \\ 15 & 15 \\ 9 & 9 \\ 0 & 5 \\ & \\ 44 & 49 \\ 80 & 89\end{array}$

BY-106
15
5
15
15
5
55
100

BY-107
15
5
15
9
0
44
80

BY-108
0
5
15
9
0
29
53

BY-109
15
3
15
9
3
45
82

$\begin{array}{ccc}\text { BY-110 } & \text { BY-111 } & \text { BY-112 } \\ 15 & 15 & 15 \\ 5 & 5 & 5 \\ 15 & 15 & 15 \\ 9 & 9 & 0 \\ 0 & 0 & 0 \\ & & \\ 44 & 44 & 35 \\ 80 & 80 & 64\end{array}$




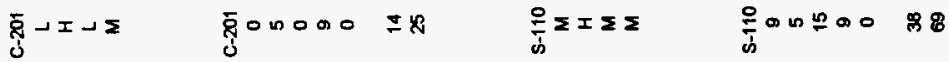

$$
\begin{aligned}
& \text { 겅 }
\end{aligned}
$$

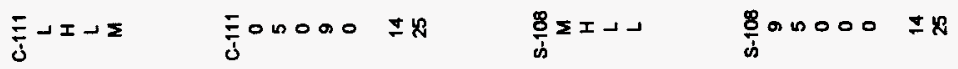

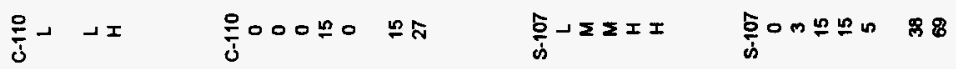

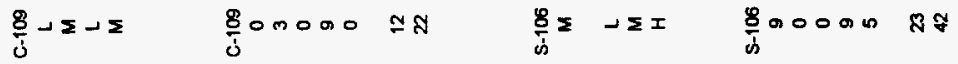

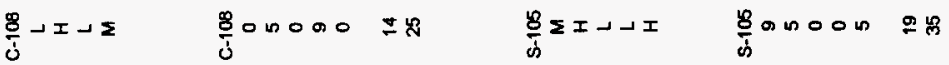

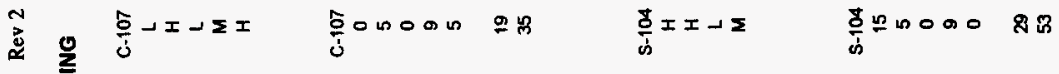

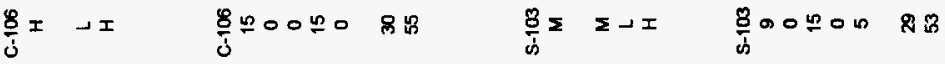

$$
\begin{aligned}
& \text { 빙 t }
\end{aligned}
$$

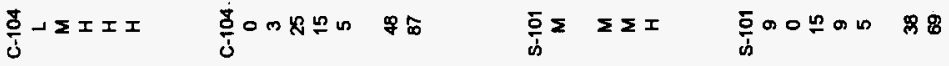

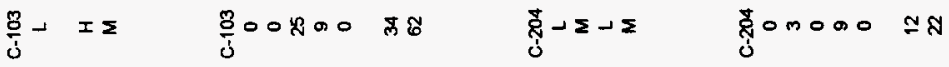

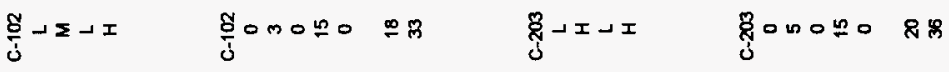

$$
\begin{aligned}
& \bar{j}
\end{aligned}
$$

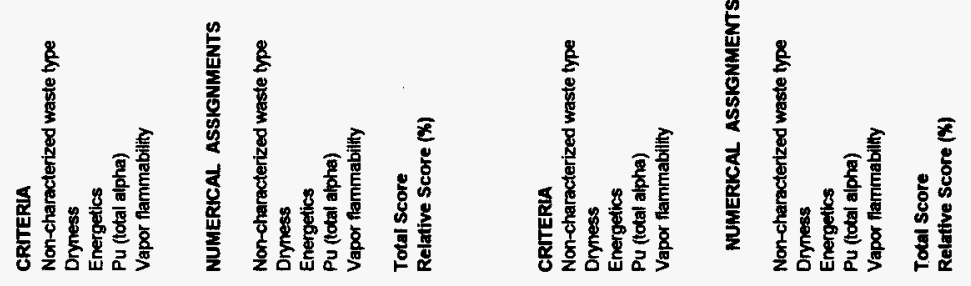


WHC-SD-WM-TA-164 Rev 2

\section{SAFETY SCREENING}

CRITERIA

Non-characterized waste type

Dryness

Energetics

Pu (total alpha)

Vapor flarnmability

NUMERICAL ASSIGNMENTS

Non-characterized waste type

Dryness

Energetks

Pu (total alpha)

Vapor flammability

Total Score

Relative Score (\%)

S-111
M
M
H

sX-101 sX-102

$\begin{array}{cc}H & M \\ H & H \\ M & H \\ M & M \\ H & H\end{array}$

sX-103

$M$
$H$
$H$
$M$
$H$

sX-104
$M$
$H$
$M$
$M$
$H$

SX-105
M
$H$
$M$
$M$
$H$

sX-106

$M$
M
H

SX-107
$H$
$H$
$L$
$M$

SX-108

$H$
$H$
$L$
$H$

$S \times-109$
$H$
$H$
$L$
$M$
$H$

$\begin{array}{cc}S X-110 & 5 X-111 \\ H & H \\ H & H \\ L & L \\ M & M\end{array}$

S-111 S-112

sx-101 sx-102

$\begin{array}{ccc}5 x-103 & s X-104 & s X-105 \\ 9 & 9 & 9\end{array}$

$\begin{array}{ccccc}\text { sX-101 } & \text { sX-102 } & \text { sX-103 } & \text { SX-104 } & \text { sX-105 } \\ 15 & 9 & 9 & 9 & 9 \\ 5 & 5 & 5 & 5 & 5 \\ 15 & 25 & 25 & 15 & 15 \\ 9 & 9 & 9 & 9 & 9 \\ 5 & 5 & 5 & 5 & 5\end{array}$

sx-106

sX-107

sX-108

sX-109 sX-110 sX-111

9
0
15
0
5

15
5
0
9
0

15
5
0
15
0

15

$15 \quad 15$

$0-5$

$\begin{array}{ll}9 & 0 \\ 5 & 5\end{array}$

38
69

49
89

$53 \quad 43$

43
78

29
53

29
53

35
64

34

$\sqrt{2+2}+2$

\section{CRITERIA}

Non-charactertzed waste type

Drymess

Energetics

Pu (total alpha)

Vapor fammability

\section{NUMERICAL ASSIGNMENTS}

\section{Non-charactertzed waste type}

Dryness

Energetics

Pu (total alpha)

Vapor flammability

Total Score

Relative Score (\%)
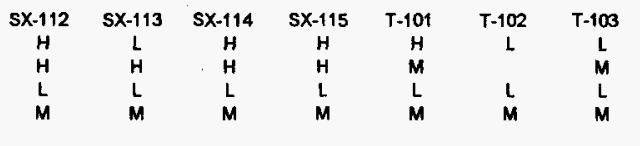

$T-104$
$L$
$M$
$H$

$T-105$
$L$
$M$
$L$

T-106

$\begin{array}{cr}T-106 & T-107 \\ L & L \\ L & L \\ M & H\end{array}$

$\begin{array}{cc}T-108 & T-109 \\ L & M \\ M & H \\ L & L \\ M & L\end{array}$

$\begin{array}{ccccc}s X-112 & s X-113 & s X-114 & s X-115 & T-101 \\ 15 & 0 & 15 & 15 & 15 \\ 5 & 5 & 5 & 5 & 3 \\ 0 & 0 & 0 & 0 & 0 \\ 9 & 9 & 9 & 9 & 9 \\ 0 & 0 & 0 & 0 & 0 \\ 29 & 14 & 29 & 29 & 27 \\ 53 & 25 & 53 & 53 & 4\end{array}$

$\begin{array}{cc}\text { T-101 } & \text { T-102 } \\ 15 & 0 \\ 3 & 0 \\ 0 & 0 \\ 9 & 9 \\ 0 & 0 \\ 27 & 9 \\ 49 & 16\end{array}$

$T-103$
0
3
0
9
0
12
22

$\mathrm{T}-104$
0
0
15
15
0

$T-105$
0
3
0
15
0

$T-106$
0
0
0
9
0
0

$\begin{array}{ccc}\text { T-107 } & \text { T-108 } & \text { T-109 } \\ 0 & 0 & 9 \\ 0 & 3 & 5 \\ 0 & 0 & 0 \\ 15 & 9 & 0 \\ 0 & 0 & 0\end{array}$

$\begin{array}{ll}30 & 18 \\ 55 & 33\end{array}$

\begin{abstract}
$53 \quad 49$
\end{abstract}




\begin{tabular}{|c|c|c|c|c|c|}
\hline$\frac{8}{\dot{x}} \pm \Sigma \Sigma$ & $\frac{8}{\grave{x}} \cong m=00$ & 88 & $\left.\frac{\bar{\sigma}}{\dot{L}}+x\right\lrcorner \Sigma$ & $\frac{\bar{g}}{\bar{r}} 00000$ & $\pm \mathbb{N}$ \\
\hline$\left.\frac{8}{x} \leq x\right\lrcorner-$ & $\frac{b}{\grave{x}}=000$ & $\mathscr{8} 8$ & $\frac{\infty}{\grave{\hbar}} I I \Sigma I$ & 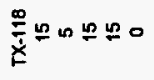 & 8 $\overline{5}$ \\
\hline$\frac{\frac{d}{d}}{\grave{x}} \pm \Sigma \Sigma \Sigma$ & 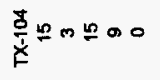 & ช্ণ & 㕈ェェ & $\frac{7}{\grave{x}}$ & \& 8 \\
\hline د & $\frac{8}{x}=0000$ & $\simeq \varnothing$ & 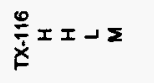 & $\frac{\Phi}{\grave{x}}=0000$ & 88 \\
\hline$\left.\frac{\delta}{\grave{d}} ェ \pm \Sigma\right\lrcorner エ$ & $\frac{\delta}{x} \curvearrowleft \infty 上 0$ & 유 & 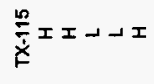 & $\frac{n}{x}=000$ n & 89 \\
\hline$\frac{\bar{\sigma}}{\grave{x}} x \sum \Sigma$ & $\frac{5}{x}=000$ & $g \pi$ & 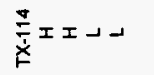 & 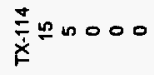 & 요 \\
\hline
\end{tabular}

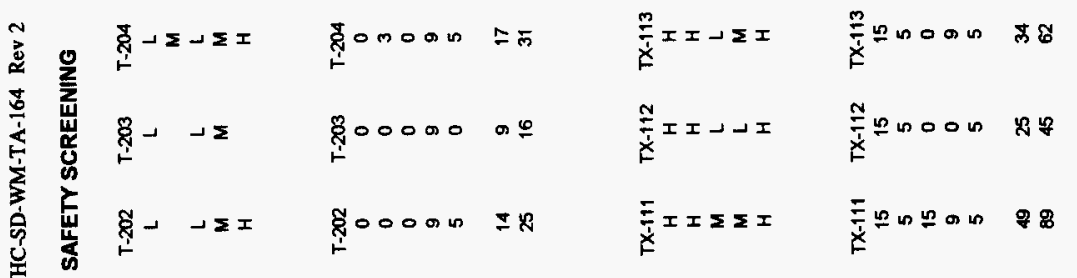

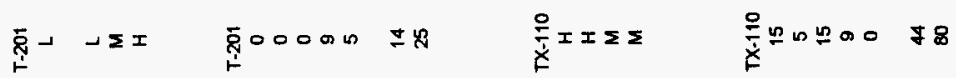

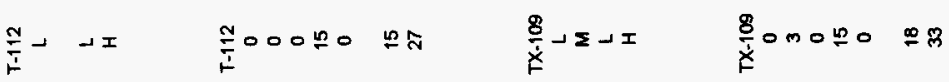

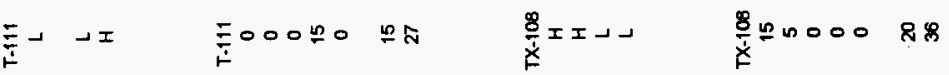

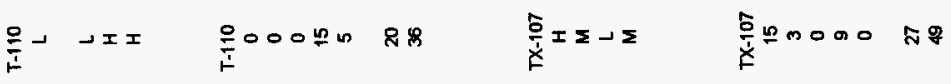

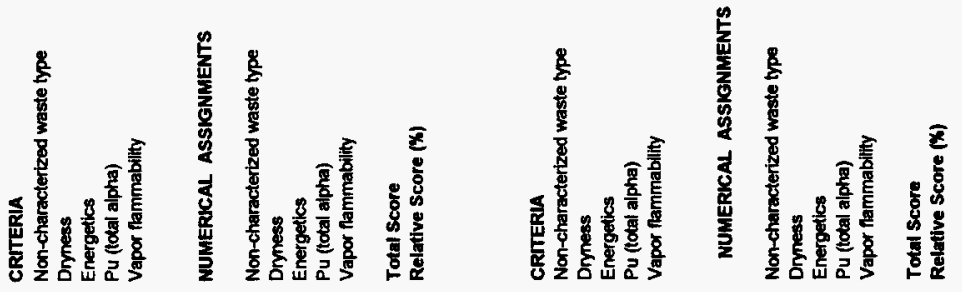


WHC-SD-WM-TA-164 Rev 2

\section{SAFETY SCREENING}

CRITERIA

Non-characterized waste type

Dryness

Energetics

Pu (total alpha)

Vapor flammability

NUMERICAL ASSIGNMENTS

Non-characterized waste type

Dryness

Energetics

Pu (total alpha)

Vapor flammability

Total Score

Relative Score (W)

\section{CRITERIA}

Non-characterized waste type

Dryness

Energetics

Pu (total alpha)

Vapor flammability

\section{NUMERICAL ASSIGNMENTS}

Non-characterized waste type

\section{Dryness}

Energetics

Pu (total alpha)

Vapor flammability

Total Score

Rekative Score (\%)

$$
\begin{array}{cccccc}
\text { TY-102 } & \text { TY-103 } & \text { TY-104 } & \text { TY-105 } & \text { TY-106 } & \text { U-101 } \\
\text { H } & \text { L } & \text { L } & \text { L } & \text { L } & \\
\text { M } & & & \text { M } & \text { H } & \text { L } \\
\text { L } & L & L & \text { L } & \text { L } & \\
\text { L } & \text { M } & \text { H } & \text { M } & \text { M } &
\end{array}
$$

$\begin{array}{ccc}\text { TY-102 } & \text { TY-103 } & \text { TY } \\ 15 & 0 \\ 3 & 0 \\ 0 & 0 \\ 0 & 9 \\ 0 & 0 \\ 18 & 9 \\ 33 & 16\end{array}$

$\begin{array}{cc}U-109 & U-110 \\ M & L \\ H & M \\ M & L \\ H & M\end{array}$

$$
\begin{array}{cc}
U-111 & U-112 \\
M & L \\
M & M \\
M & L \\
M & M \\
H &
\end{array}
$$

U-201
$\mathrm{L}$
$\mathrm{L}$
$\mathrm{M}$

$\mathrm{U}-202$
$\mathrm{~L}$
$\mathrm{M}$

U-203

$U-204$

AN-101

AN-10

AN-10

AN-104 AN-105

$\begin{array}{llll}L & L & L & H \\ M & M & M & L\end{array}$

$\begin{array}{ll}H & H \\ L & \text { L }\end{array}$

$\begin{array}{ll}H & H \\ L & \text { L } \\ H & \text { H }\end{array}$

H

H

$\begin{array}{ccccccccccccc}U-109 & U-110 & U-111 & U-112 & U-201 & U-202 & U-203 & U-204 & \text { AN-101 } & \text { AN-102 } & \text { AN-103 } & \text { AN-104 } & \text { AN-105 } \\ 9 & 0 & 9 & 0 & 0 & 0 & 0 & 0 & 0 & 9 & 15 & 15 & 0 \\ 0 & 3 & 3 & 3 & 0 & 0 & 0 & 0 & 0 & 0 & 0 & 0 & 0 \\ 25 & 0 & 15 & 0 & 0 & 0 & 0 & 0 & 0 & 25 & 25 & 25 & 25 \\ 9 & 9 & 9 & 9 & 9 & 9 & 9 & 9 & 9 & 0 & 0 & 0 & 0 \\ 5 & 0 & 5 & 0 & 0 & 0 & 0 & 0 & 0 & 0 & 5 & 5 & 5 \\ 48 & 12 & 41 & 12 & 9 & 9 & 9 & 9 & 9 & 34 & 45 & 45 & 30 \\ 87 & 22 & 75 & 22 & 16 & 16 & 16 & 16 & 16 & 62 & 82 & 82 & 55\end{array}$


WHC-SD-WM-TA-164 Rev 2

\begin{tabular}{|c|c|c|c|c|c|c|c|c|c|c|c|c|c|}
\hline CRITERIA & AN-106 & AN-107 & AP-101 & AP-102 & AP- 103 & AP-104 & AP.105 & AP-106 & AP-107 & AP-108 & $A W-101$ & $A W-102$ & AW-103 \\
\hline $\begin{array}{l}\text { Non-characterized waste type } \\
\text { Dryness }\end{array}$ & M & $M$ & $L$ & $L$ & $\mathbf{L}$ & $\mathbf{L}$ & $\mathbf{L}$ & $\mathbf{L}$ & L & $\mathbf{L}$ & $\mathbf{M}$ & $\mathbf{M}$ & $\mathbf{L}$ \\
\hline $\begin{array}{l}\text { Energetics } \\
\text { Pu (total alpha) } \\
\text { Vapor flammability }\end{array}$ & $M$ & $\begin{array}{l}\mathrm{H} \\
\mathbf{L} \\
\mathrm{H}\end{array}$ & $\mathrm{L}$ & M & $\mathbf{L}$ & L & $M$ & $\mathbf{L}$ & $\mathbf{L}$ & $\mathbf{L}$ & $\begin{array}{l}H \\
M \\
H\end{array}$ & M & $\stackrel{L}{M}$ \\
\hline \multicolumn{14}{|l|}{ NUMERICAL ASSICNMENTS } \\
\hline & AN-106 & AN-107 & AP-101 & AP-102 & AP-103 & AP-104 & $A P-105$ & AP -106 & AP-107 & AP-108 & AW-101 & AW-102 & AW-103 \\
\hline Non-characterized waste type & 9 & 9 & 0 & 0 & 0 & 0 & $\mathbf{0}$ & 0 & 0 & $\mathbf{0}$ & 9 & 9 & $\mathbf{0}$ \\
\hline Dryness & $\mathbf{0}$ & 0 & 0 & 0 & 0 & 0 & 0 & 0 & 0 & 0 & 0 & 0 & 0 \\
\hline Energetics & 15 & $\mathbf{2 5}$ & 0 & 15 & 0 & 0 & 15 & $\mathbf{0}$ & 0 & 0 & 25 & 15 & o \\
\hline Pu (total alpha) & 0 & 0 & 0 & 0 & 0 & 0 & 0 & 0 & 0 & 0 & 9 & 0 & 9 \\
\hline Vapor flammability & 0 & 5 & 0 & 0 & 0 & 0 & 0 & 0 & 0 & 0 & 5 & 0 & 0 \\
\hline Total Score & 24 & 39 & 0 & 15 & 0 & 0 & 15 & 0 & 0 & 0 & 48 & 24 & 9 \\
\hline Relative Score (\%) & 44 & 71 & 0 & 27 & 0 & 0 & 27 & 0 & 0 & 0 & 87 & 44 & 16 \\
\hline CRITERIA & AW-104 & AW-105 & AW-106 & $A Y-101$ & AY-102 & $A Z-101$ & AZ-102 & SY-101 & SY-102 & SY-103 & & & \\
\hline $\begin{array}{l}\text { Non-characterized waste hpe } \\
\text { Dryness }\end{array}$ & $M$ & L & $M$ & L & L & H & L & $M$ & $M$ & $M$ & & & \\
\hline Energetics & $\mathbf{L}$ & $\mathbf{L}$ & $\mathbf{M}$ & $\mathbf{H}$ & $\mathbf{L}$ & $\mathrm{L}$ & $\mathbf{L}$ & $\mathrm{H}$ & $L$ & $M$ & & & \\
\hline Pu (total alpha) & $\mathbf{M}$ & $\mathbf{M}$ & $L$ & $\mathbf{M}$ & M & $\mathbf{M}$ & $\mathbf{M}$ & $\mathbf{M}$ & $\mathbf{H}$ & $\mathbf{L}$ & & & \\
\hline Vapor flammabitly & $H$ & & & H & & & & $\mathbf{H}$ & & H & & & \\
\hline \multicolumn{14}{|c|}{ NUMERICAL ASSIGNMENTS } \\
\hline & AW-104 & AW-105 & AW-100 & AY-101 & AY-102 & AZ-101 & AZ-102 & SY-101 & SY-102 & SY-103 & & & \\
\hline Non-charactertzed woste type & 9 & 0 & 9 & 0 & o & 15 & 0 & 9 & 9 & 9 & & & \\
\hline Dryness & 0 & 0 & 0 & 0 & 0 & 0 & 0 & 0 & 0 & 0 & & & \\
\hline Energetics & $\mathbf{0}$ & 0 & 15 & 25 & 0 & 0 & 0 & 25 & 0 & 15 & & & \\
\hline Pu (total aipha) & 9 & 9 & 0 & 9 & 9 & 9 & 9 & 9 & 15 & 0 & & & \\
\hline Vapor flammability & 5 & 0 & 0 & $\mathbf{5}$ & 0 & 0 & 0 & 5 & 0 & 5 & & & \\
\hline Total Score & 23 & 9 & 24 & 39 & 9 & 24 & 9 & 48 & 24 & 29 & & & \\
\hline Relative Score (\%) & 42 & 16 & 44 & 71 & 16 & 44 & 16 & 87 & 44 & 53 & & & \\
\hline
\end{tabular}


WHC-SD-WM-TA-164 Rev. 2

APPENDIX C4

VAPOR SCREENING

C4-1 
WHC-SD-WM-TA-164 Rev. 2

This page intentionally left blank. 
WHC-SD-WM-TA-164 Rev 2

\section{VAPOR SCREENING}

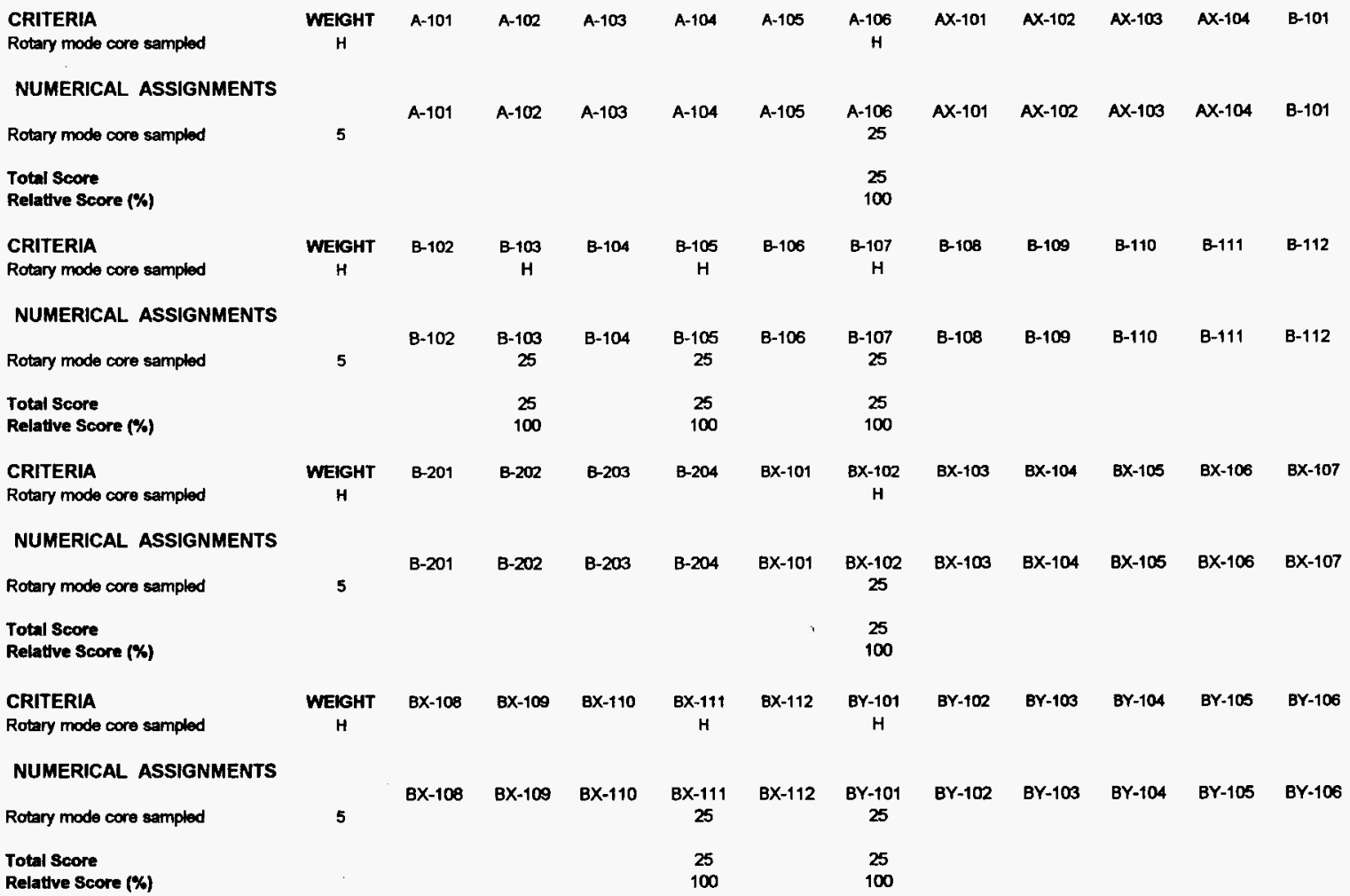


WHC-SD-WM-TA-164 Rev 2

\section{VAPOR SCREENING}

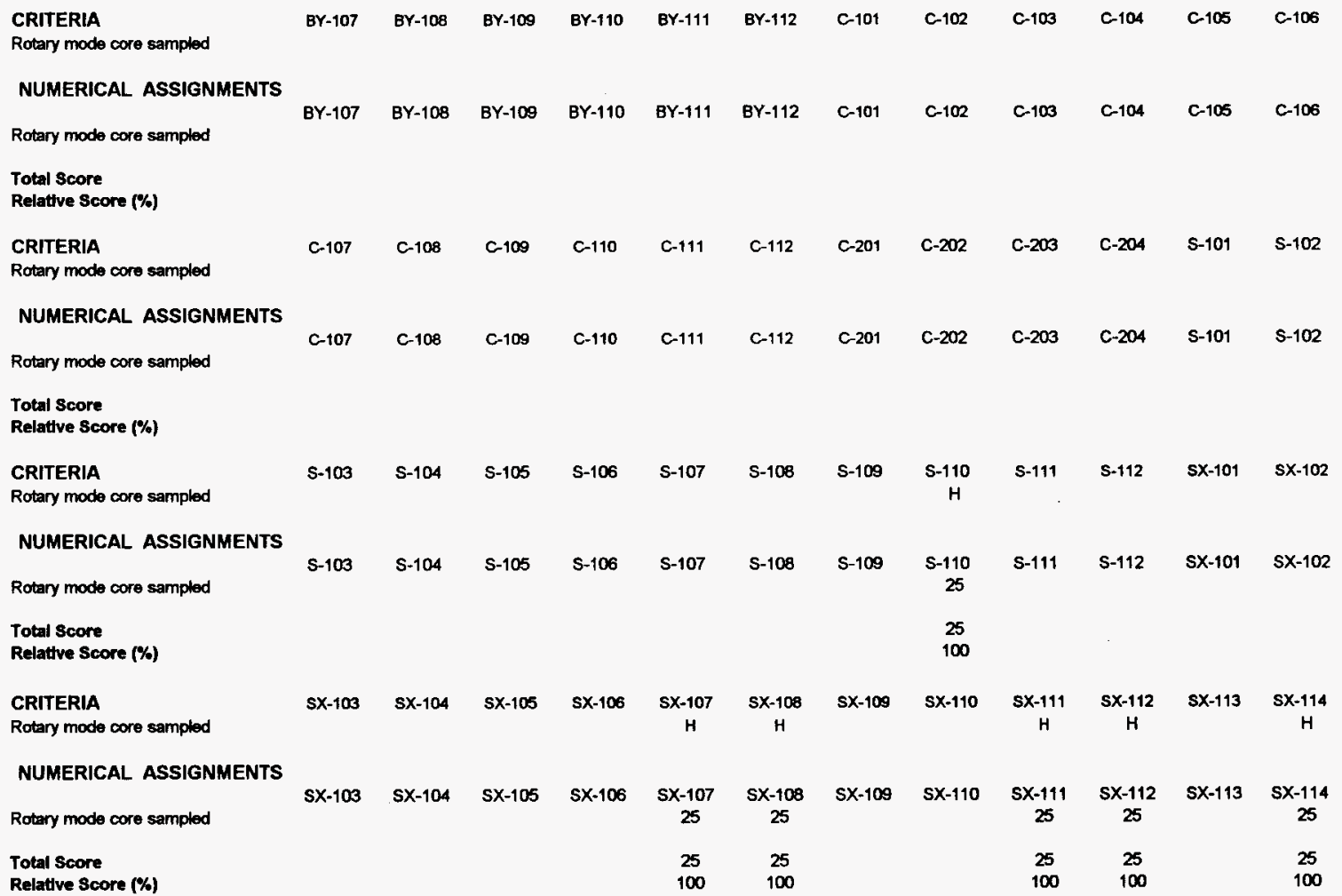




\section{WHC-SD-WM-TA-164 Rev 2}

\begin{tabular}{|c|c|c|c|c|c|c|c|c|c|c|c|c|}
\hline $\begin{array}{l}\text { CRITERIA } \\
\text { Rotary mode core sampled }\end{array}$ & $5 x-115$ & $\begin{array}{c}T-101 \\
H\end{array}$ & $T-102$ & $T-103$ & $T-104$ & $T-105$ & $T-106$ & T-107 & $T-108$ & $T-109$ & $T-110$ & $T-111$ \\
\hline \multicolumn{13}{|c|}{ NUMERICAL ASSIGNMENTS } \\
\hline Rotary mode core sampled & $s \times-115$ & $\begin{array}{c}T-101 \\
25\end{array}$ & $\mathrm{~T}-102$ & $T-103$ & $T-104$ & $\mathrm{~T}-105$ & $T-106$ & $T-107$ & $T-108$ & $T-109$ & $T-110$ & $T-111$ \\
\hline $\begin{array}{l}\text { Total Score } \\
\text { Relattve Score (\%) }\end{array}$ & & $\begin{array}{c}25 \\
100\end{array}$ & & & & & & & & & & \\
\hline CRITERIA & $T-112$ & $T-201$ & $\mathrm{~T}-202$ & $T-203$ & $T-204$ & TX-101 & $T X-102$ & $7 x-103$ & $7 X-104$ & TX-105 & $7 x-106$ & $T X-107$ \\
\hline Rotary mode core sampled & & H & H & $\mathrm{H}$ & $\mathbf{H}$ & $\mathbf{H}$ & H & $\mathbf{H}$ & H & & H & \\
\hline \multicolumn{13}{|c|}{ NUMERICAL ASSIGNMENTS } \\
\hline & $\mathrm{T}-112$ & $T-201$ & $\mathrm{~T}-202$ & $T-203$ & $T-204$ & $T X-101$ & $\mathrm{TX}-102$ & $T X-103$ & $T X-104$ & TX-105 & $T \times-106$ & TX-107 \\
\hline Rotary mode core sampled & & 25 & 25 & 25 & 25 & 25 & 25 & 25 & 25 & & 25 & \\
\hline $\begin{array}{l}\text { Total Score } \\
\text { Relative Score (\%) }\end{array}$ & & $\begin{array}{c}25 \\
100\end{array}$ & $\begin{array}{c}25 \\
100\end{array}$ & $\begin{array}{c}25 \\
100\end{array}$ & $\begin{array}{c}25 \\
100\end{array}$ & $\begin{array}{c}25 \\
100\end{array}$ & $\begin{array}{c}25 \\
100\end{array}$ & $\begin{array}{c}25 \\
100\end{array}$ & $\begin{array}{c}25 \\
100\end{array}$ & & $\begin{array}{c}25 \\
100\end{array}$ & \\
\hline CRITERIA & $T X-108$ & $T X-109$ & $7 x-110$ & TX-111 & $T X-112$ & $T X-113$ & TX-114 & $T X-115$ & $T X-116$ & $T X-117$ & TX-118 & Tr-101 \\
\hline Rotary mode core sampled & H & $\mathrm{H}$ & $\mathrm{H}$ & & $\mathrm{H}$ & H & H & $\mathrm{H}$ & H & H & & \\
\hline \multicolumn{13}{|c|}{ NUMERICAL ASSIGNMENTS } \\
\hline & $T X-108$ & TX-109 & $T X-110$ & TX-141 & TX-112 & $T X-113$ & $T X-114$ & TX-115 & TX-116 & $T X-117$ & $T X-118$ & TY-101 \\
\hline Rotary mode core sampled & 25 & 25 & 25 & $\cdot$ & 25 & 25 & 25 & 25 & 25 & 25 & & \\
\hline Total Score & 25 & 25 & 25 & & 25 & 25 & 25 & 25 & 25 & 25 & & \\
\hline Relative score (\%) & 100 & 100 & 100 & & 100 & 100 & 100 & 100 & 100 & 100 & & \\
\hline $\begin{array}{l}\text { CRITERIA } \\
\text { Rotary mode core sampled }\end{array}$ & Tr-102 & $T Y-103$ & $T Y-104$ & $\begin{array}{c}T r-105 \\
H\end{array}$ & $T r-106$ & U-101 & $U-102$ & U-103 & $\mathrm{U}-104$ & $U-105$ & U-106 & $U-107$ \\
\hline \multicolumn{13}{|c|}{ NUMERICAL ASSIGNMENTS } \\
\hline Rotary mode core sampled & TY-102 & TY-103 & TY-104 & $\begin{array}{c}\text { TY-105 } \\
25\end{array}$ & TY-106 & U-101 & U-102 & $U-103$ & $U-104$ & U-105 & U-106 & U-107 \\
\hline $\begin{array}{l}\text { Total Score } \\
\text { Relattve Score }(\%)\end{array}$ & & & & $\begin{array}{c}25 \\
100\end{array}$ & & & & & & & & \\
\hline
\end{tabular}




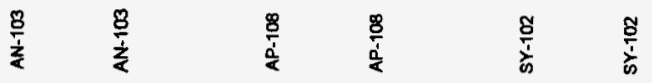

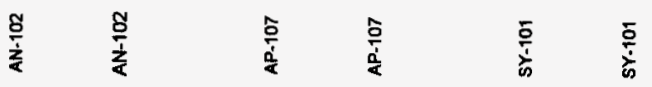

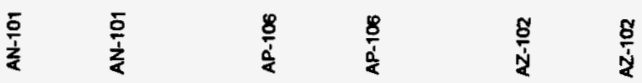

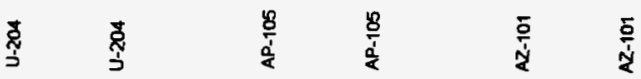

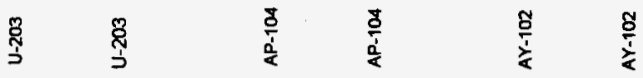

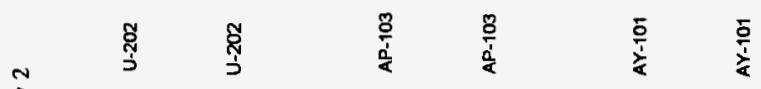

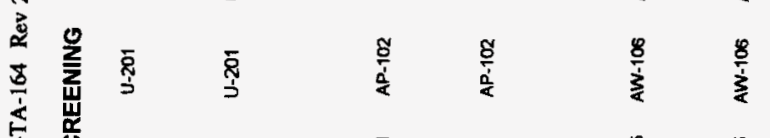

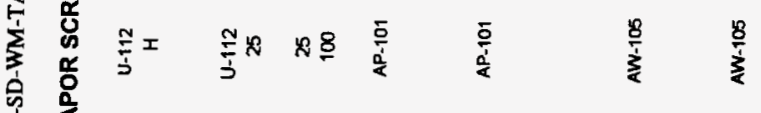

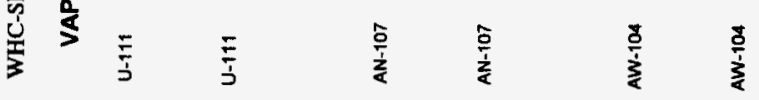

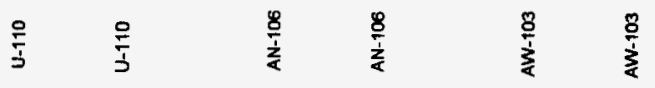

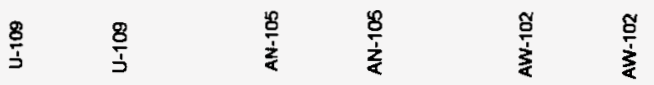

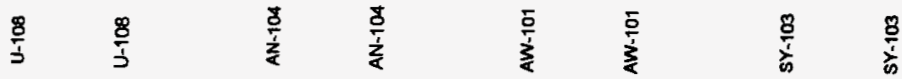

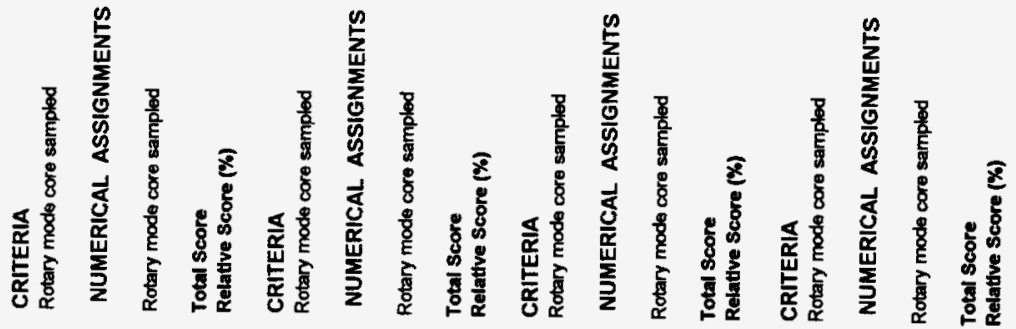


WHC-SD-WM-TA-164 Rev. 2

APPENDIX C5

VAPOR PHENOMENOLOGY

C5-1 
WHC-SD-WM-TA-164 Rev. 2

This page intentionally left blank.

C5-2 
WHC-SD-WM-TA-164 Rev 2

\section{VAPOR PHENOMENOLOGY}

\section{CRITERIA}

Temporal study

Mixing study

Ventilation study

$\begin{array}{cc}\text { WEIGHT } & \text { B-103 } \\ \mathbf{H} & \\ \mathbf{H} & \mathbf{H} \\ \mathbf{H} & \end{array}$

$\begin{array}{cc}B X-104 & B Y-108 \\ H & H\end{array}$

C-107

S-102

U-112

$\mathrm{H}$

H

H

H

H H

NUMERICAL ASSIGNMENTS

Temporal study

Mixing study

Ventilation study

Total Score

Relative Score (\%)

$\begin{array}{cccccccc} & \text { B-103 } & \text { BX-104 } & \text { BY-108 } & \text { C-107 } & \text { S-102 } & \text { TY-103 } & \text { U-112 } \\ 5 & 0 & 25 & 25 & 25 & 25 & 0 & 0 \\ 5 & 25 & 0 & 0 & 0 & 0 & 25 & 25 \\ 5 & 0 & 0 & 0 & 0 & 25 & 0 & 0 \\ & & & & & & & \\ & 25 & 25 & 25 & 25 & 50 & 25 & 25 \\ & 50 & 50 & 50 & 50 & 100 & 50 & 50\end{array}$


WHC-SD-WM-TA-164 Rev. 2

This page intentionally left blank. 
WHC-SD-WM-TA-164 Rev. 2

APPENDIX C6

PRIVATIZATION 
WHC-SD-WM-TA-164 Rev. 2

This page intentionally left blank. 
WHC-SD-WM-TA-164 Rev 2

\section{PRIVATIZATION}

CRITERIA
Sequence for staging waste to private

vendors

Date When DST is available as feed

Provide waste for feed envelopes

NUMERICAL ASSIGNMENTS

Sequence for staging waste to private vendors

Date When DST is available as feed Provide waste for feed envelopes

Total Score

Relattve Score (\%)

\section{CRITERIA}

Sequence for staging waste to private vendors

Date When DST is available as feed

Provide waste for feed envelopes

\section{NUMERICAL ASSIGNMENTS}

Sequence for staging waste to private vendors

Date When DST is available as feed

Provide waste for feed envelopes

Total Score

Relattve Score (\%)

WEIG

EIGHT
$M$
H

C-106

AN-10t

AN-102

AN-103

AN-104

AN-105

AN-106

AN-107

AP-101

AP-102

H H

$\begin{array}{ll}H & H \\ H & H\end{array}$

$\begin{array}{ll}H & H \\ H & H\end{array}$

H
H

C-106

AN-101

AN-102

AN-103

AN-104

AN-105

AN-106

AN-107

AP-101

AP-102

3
3
5

9
0
25
34
62

15
15
0
30

$\begin{array}{ll}15 & 15 \\ 15 & 15\end{array}$

30
55

15
15
0
30
55

15
15
0
30
55

15

15
0

0

15
15
25
55
100

15
25
55
100

0
0
0
0
0

15
15
25
55

0

15

0

0
0

0

27

AP-103

AP-104

AP-105

AP-106

AP-107

AP-108

AW+101

AW-102

AW-103 AW-104

M

M

H

L
H

L

L

H

$\mathrm{L}$

H

AP-103

AP-104

AP-105

AP-106

AP-107

AP +108

AW-101

AW-102 AW-103 AW-104

3

0
15
0
15
27

15
15
0
30
55

0
15
0
15
27

15
15
25
55
100

0
0
0
0
0

$\begin{array}{ll}0 & 0 \\ 0 & 0 \\ 0 & 0 \\ 0 & 0 \\ 0 & 0\end{array}$


WHC-SD-WM-TA-164 Rev 2

\section{PRIVATIZATION}

CRITERIA

Sequence for staging waste to private vendors

Dato When DST is available as feed Provide waste for feed envelopes

\section{NUMERICAL ASSIGNMENTS}

Sequence for staging waste to private vendors

Date When DST is available as feed

Provide waste for feed envelopes

Total score

Relative Score (\%)

\section{CRITERIA}

Sequence for staging waste to private vendors

Date When DST is available as feed Provide waste for feed envelopes

\section{NUMERICAL ASSIGNMENTS}

Sequence for staging waste to private vendors

Date When DST is available as feed

Provide waste for feed envelopes

Total Score

Relative Score (\%)
AW-105 AW-106

AY-101

AY-102

$A Z-101$

$A Z-102$

SY-101

SY-102

SY-103

L L

H

M

M
L

\section{M}

L

L

AW-105 AW-105

AY-101

AY-102

AZ-101

AZ-102

SY-101

SY-102

SY-103

$\begin{array}{ccc}0 & 0 & 15 \\ 0 & 0 & 0 \\ 0 & 0 & 0 \\ 0 & 0 & 15 \\ 0 & 0 & 27\end{array}$

9
0
0
9
16

9
0
0
9
16

9

0

15

0

15
27

0

15

0

15
27 
WHC-SD-WM-TA-164 Rev. 2

APPENDIX C7-1

PROCESS TESTING-SLUDGE WASHING

C7-1-1 
WHC-SD-WM-TA-164 Rev. 2

This page intentionally left blank. 
WHC-SD-WM-TA-164 Rev 2

\section{PROCESS TESTING - Sludge Washing}

\section{CRITERIA}

Fill history (waste types)

Self boiling tanks (Redox only)

Key analytes - $\mathrm{Cr}$

Koy analytes - Al

High sludge inventory

High salt cake inventon

NUMERICAL ASSIGNMENTS

Fill history (waste types)

Self bolling tanks (Redox only)

Key analytes - $\mathrm{Cr}$

Key analytes - A

High sludge inventory

High salt cake inventory

Total

Relative total (\%)

\section{CRITERIA}

Fill history (waste types)

Self boiling tanks (Redox only)

Key analytes - $\mathrm{Cr}$

Key analytes - A

High sludge inventory

High salt cake inventory

\section{NUMERICAL ASSIGNMENTS}

Fill history (waste types)

Self boiling tanks (Redox only)

Key analytes $-\mathrm{Cr}$

Key analytes - $\mathbf{A}$

High sludge inventory

High salt cake inventory

Total

Relattve total (\%)

$\begin{array}{ccccccc}\text { WEIGHT } & \text { A-101 } & \text { B-103 } & \text { B-104 } & \text { B-106 } & \text { B-110 } & \text { B-111 } \\ \text { H } & \text { L } & \text { L } & \text { M } & \text { L } & \text { M } & \\ \text { M } & & & & & \\ \text { H } & \text { L } & \text { L } & \text { L } & \text { L } & \text { L } \\ \text { M } & \text { L } & \text { L } & \text { L } & \text { L } & \text { L } \\ \text { M } & & \text { L } & \text { H } & \text { L } & \text { H } \\ \text { L } & \text { H } & \text { M } & \text { M } & \text { M } & \end{array}$

5
3
5
3
1

$\begin{array}{cc}\text { A-101 } & \text { B-103 } \\ 0 & 0 \\ 0 & 0 \\ 0 & 0 \\ 0 & 0 \\ 0 & 0 \\ 5 & 3 \\ 5 & 3 \\ 2 & 0\end{array}$

B-104
15
0
0
0
15
3
33
35

$\begin{array}{cc}\text { B-106 } & \text { B-110 } \\ 0 & 15 \\ 0 & 0 \\ 0 & 0 \\ 0 & 0 \\ 0 & 15 \\ 3 & 0 \\ 3 & 30 \\ 0 & 31\end{array}$

B-111
15
0
0
0
15
0
30
31

$\begin{array}{ccc}\text { B-202 } & \text { BX-103 } & \text { BX-105 } \\ 15 & 15 & 15 \\ 0 & 0 & 0 \\ 0 & 0 & 0 \\ 0 & 0 & 0 \\ 0 & 9 & 0 \\ 0 & 0 & 0 \\ 15 & 24 & 15 \\ 14 & 24 & 14\end{array}$

$\begin{array}{ccc}\text { WEKGHT } & \text { BX-107 } & \text { BX-109 } \\ \text { H } & \text { M } & \text { M } \\ \text { M } & & \\ H & L & L \\ M & L & L \\ M & H & H\end{array}$

\section{$B X-110$}

BY-10

BY-105

BY-108

$\underset{M}{\text { BY-110 }}$

$\begin{array}{ccc}\text { C-103 } & \text { C-104 } & \text { C-105 } \\ \text { M } & \text { M } & \text { M } \\ \text { L } & \text { L } & \text { L } \\ \text { M } & \text { H } & \text { H } \\ \text { M } & \text { H } & \text { M }\end{array}$

BX-107 BX-109 BX-110

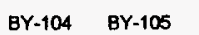

$$
\begin{gathered}
0 \\
0 \\
0 \\
0 \\
15 \\
5 \\
20 \\
20
\end{gathered}
$$

$\begin{array}{cc}B Y-105 & B Y-108 \\ 0 & 15 \\ 0 & 0 \\ 0 & 0 \\ 9 & 0 \\ 15 & 15 \\ 5 & 3 \\ 29 & 33 \\ 30 & 35\end{array}$

BY-110

C-103

C-104

C-106

15
0
0
0
15
5

15
0
0
9
9
0

$15 \quad 15$

0

$15 \quad 15$

15 
WHC-SD-WM-TA-164 Rev 2

PROCESS TESTING - Sludge Washing

CRITERIA

Fill history (waste types)

Self boiling tanks (Redox only)

Key analytes - $\mathrm{Cr}$

Key analytes - $\mathbf{A}$

High sludge inventory

High salt cake inventory

\section{NUMERICAL ASSIGNMENTS}

Fill history (waste types)

Self boiling tenks (Redox only)

Koy analytes - $\mathrm{Cr}$

Key analytes - A

High sludge inventory

High salt cake inventory

\section{Total}

Relative total (\%)

\section{CRITERIA}

Fill history (waste types)

Self boiling tanks (Redox only)

Koy analytes - $\mathrm{Cr}$

Key analytes - $\mathrm{Al}$

High studge imventory

High salt cake inventory

\section{NUMERICAL ASSIGNMENTS}

Fill history (waste types)

Self boiling tanks (Redox only)

Key analytes $-\mathrm{Cr}$

Key anaiytes - A

High sludge inventory

High salt cake inventory

Total

Relative total (\%)

$\begin{array}{ccccc}\text { C-107 } & \text { C-108 } & \text { C-109 } & \text { C-112 } & \text { S-10t } \\ \text { M } & M & M & M & \text { L } \\ \text { L } & \text { L } & \text { L } & \text { L } & \text { M } \\ \text { L } & \text { M } & \text { L } & \text { L } & \text { M } \\ \text { H } & \text { M } & \text { M } & \text { M } & \text { M } \\ & & & & H\end{array}$

$5-104$
$H$
$H$
$M$
$H$
$M$
$H$

$\begin{array}{cccc}\text { C-107 } & \text { C-108 } & \text { C-109 } & \text { C-112 } \\ 15 & 15 & 15 & 15 \\ 0 & 0 & 0 & 0 \\ 0 & 0 & 0 & 0 \\ 0 & 9 & 0 & 0 \\ 15 & 9 & 9 & 9 \\ 0 & 0 & 0 & 0 \\ 30 & 33 & 24 & 24 \\ 31 & 35 & 24 & 24\end{array}$

$\begin{array}{cc}s \times-109 & s \times-110 \\ H & H \\ H & \\ M & H \\ M & M \\ M & L \\ H & L\end{array}$

$S X-113 \quad T-103 \quad T-104$

$\begin{array}{ccc}S X-113 & T-103 & T-104 \\ M & M & \\ H & \\ M & L \\ L & H \\ & L\end{array}$

$s \times-109$
25
15
15
9
9
5

78
87

$\begin{array}{ccc}S X-110 & S X-113 & T-103 \\ 25 & 15 & 15 \\ 0 & 15 & 0 \\ 25 & 15 & 0 \\ 9 & 0 & 15 \\ 0 & 0 & 0 \\ 0 & 0 & 0 \\ 59 & 45 & 30\end{array}$

65
S-101

S-104

$\mathrm{T}-107$

T-107

30

30

S-107
$M$
S-1
H
H
M

$S-110$
$L$
$M$
$M$
$M$
$H$

$s \times-101$
$H$
$H$
$M$
$M$
$H$
$H$

sx-104

$\begin{array}{lcc}L & H & H \\ H & H & H \\ M & M & H \\ M & H & H \\ M & M & M \\ H & L & \end{array}$

S-107
15
0
15
15
15
3

$\begin{array}{ccccc}\text { S-110 } & \text { SX-101 } & \text { sX-104 } & \text { sX-107 } & \text { sX-108 } \\ 0 & 25 & 0 & 25 & 25 \\ 0 & 15 & 15 & 15 & 15 \\ 15 & 15 & 15 & 15 & 25 \\ 9 & 9 & 9 & 15 & 15 \\ 9 & 15 & 9 & 9 & 9 \\ 5 & 5 & 5 & 0 & 0\end{array}$

$63 \quad 38$

$84 \quad 53$

$79 \quad 69$

84
94

41

$T-109 \quad T-111$

TX-111

TX-116 TX-118 TY-104

L

L

H

L

$\mathrm{L}$

M

L

L L

H

H

L

$T-109$

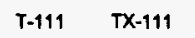

TX-116

TX-118 TY-104

150000015

0

$\mathbf{0}$

0

15
0

0
0
0

0

5

0
0
0
0
5

0

0

0

0

o

31 
WHC-SD-WM-TA-164 Rev 2

\section{PROCESS TESTING - Sludge Washing}

\section{CRITERIA}

Fill history (waste types)

Self boiling tanks (Redox only)

Koy analytes $-\mathrm{Cr}$

Koy analytes - Al

High sludge inventory

High salt cake inventory

\section{NUMERICAL ASSIGNMENTS}

Fill history (waste types)

Self boiling tanks (Redox only)

Key analytes $-\mathrm{Cr}$

Key analytes - Al

High sludge inventory

High salt cake inventory

Total

Relattve total (\%)

\section{CRITERIA}

Fill history (waste types)

Self boiling tanks (Redox only)

Key analytes - $\mathrm{Cr}$

Koy analytes - $\mathrm{A}$

High sludge inventory

High salt cake inventory

\section{NUMERICAL ASSIGNMENTS}

Fill history (wasto types)

Self boiling tanks (Redox only)

Koy analytes - $\mathrm{Cr}$

Key analytes - A

High sludge inventory

High salt cake inventory

Total

Relative total (\%)

$\begin{array}{ccc}\text { TY-105 } & \text { U-109 } & \text { U-110 } \\ M & L & M \\ L & L & L \\ L & M & L \\ H & L & H\end{array}$

$\begin{array}{ccc}\text { TY-105 } & \text { U-109 } & \text { U-110 } \\ 15 & 0 & 15 \\ 0 & 0 & 0 \\ 0 & 0 & 0 \\ 0 & 9 & 0 \\ 15 & 0 & 15 \\ 0 & 5 & 0 \\ 30 & 14 & 30 \\ 31 & 13 & 31\end{array}$


WHC-SD-WM-TA-164 Rev. 2

This page intentionally left blank. 
WHC-SD-WM-TA-164 Rev. 2

APPENDIX C7-2

PROCESS TESTING - SUPERNATANT PRETREATMENT

C7-2-1 
WHC-SD-WM-TA-164 Rev. 2

This page intentionally left blank. 
WHC-SD-WM-TA-164 Rev 2

PROCESS TESTING - Supernatant Pretreatment

CRITERIA

Suitable DSSF

Sultable CC

Suitable NCAW

Suitable NCRW

\section{NUMERKAL ASSIGNMENTS}

Suitable DSSF

Suitabie CC

Suitable NCAW

Suitable NCRW

Total

Relative total (\%)

CRTERLA

Suitable DSSF

Suitable CC

Suitable NCAW

Suitable NCRW

NUMERICAL ASSIGNMENTS

Suitable DSSF

Suitable CC

Suitable NCAW

Suitable NCRW

Total

Relative total (\%)

WEIGHT AN

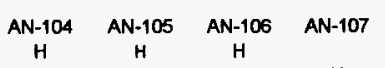

$\mathrm{H}$

5
5
1

$\begin{array}{cccc}\text { AN-102 } & \text { AN-104 } & \text { AN-105 } & \text { AN-106 } \\ 0 & 25 & 25 & 25 \\ 25 & 0 & 0 & 0 \\ 0 & 0 & 0 & 0 \\ 0 & 0 & 0 & 0 \\ 25 & 25 & 25 & 25\end{array}$

$100 \quad 100$

100

100

WEIGHT
H
H
M
L

AZ-101

AZ-102

H H

$\begin{array}{ccc} & A Z-101 & A Z-102 \\ 5 & 0 & 0 \\ 5 & 0 & 0 \\ 3 & 15 & 15 \\ 1 & 0 & 0 \\ & 15 & 15 \\ & 50 & 50\end{array}$

AP-101 AP-105 AW-101 AW-103 AW-105

H H H

H

H H

$\begin{array}{cccccc}\text {-107 } & \text { AP-101 } & \text { AP-105 } & \text { AW-101 } & \text { AW-103 } & \text { AW-105 } \\ 0 & 25 & 25 & 25 & 0 & 0 \\ 25 & 0 & 0 & 0 & 0 & 0 \\ 0 & 0 & 0 & 0 & 0 & 0 \\ 0 & 0 & 0 & 0 & 5 & 5 \\ 25 & 25 & 25 & 25 & 5 & 5 \\ 100 & 100 & 100 & 100 & 0 & 0\end{array}$


WHC-SD-WM-TA-164 Rev. 2

This page intentionally left blank. 


\section{WHC-SD-WM-TA-164 Rev. 2}

APPENDIX C8

\section{RETRIEVAL}


WHC-SD-WM-TA-164 Rev. 2

This page intentionally left blank.

\section{C8-2}


WHC-SD-WM-TA-164 Rev 2

RETRIEVEL

CRITERIA

Retrievel Need

NUMERICAL ASSIGNMENTS

Retrievel Need

Total Score

Relative score (\%)
WEIGHT

$$
\text { H }
$$

AX-10

L

Ax-104

C-106

AY-1

AZ-101

$\mathrm{H}$

$H$

$\mathrm{H}$

$\mathrm{H}$

$A \times-103$

Ax-104

C-106

AY-102

AZ-101

5

0

$0 \quad 25$

25
100

25

25

25

$\begin{array}{ccccc}0 & 25 & 25 & 25 & 25 \\ 0 & 100 & 100 & 100 & 100\end{array}$ 
WHC-SD-WM-TA-164 Rev. 2

This page intentionally left blank. 
WHC-SD-WM-TA-164 Rev. 2

APPENDIX C9

\section{HISTORICAL MODEL EVALUATIONS}

C9-1 
WHC-SD-WM-TA-164 Rev 2

CRITERIA

Typical Redox

Typical salt cake

Typical Pursx

Typical UR waste

Greatest spatial variability - vertical

Greatest spatial variability - horizontal

\section{NUMERICAL ASSIGMENTS}

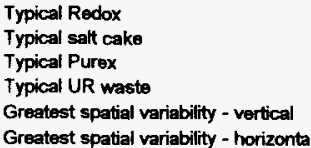

Greatest spatial variability - horizontal

Total Score

Relative Score (\%)

\section{CRITERIA}

Typical Redox

Typical salt cake

Typical Purex

Typical UR waste

Greatest spatial variability - verticad

Greatest spatial variability - horizontal

\section{NUMERICAL ASSIGMENTS}

Typical Redox

Typical salt cake

Typical Purex

Typical UR waste

Greatest spatial variability - vertical

Greatest spatial variability - horizontal

Total Score

Relative Score (\%)
HISTORICAL MODEL EVALUATION

\begin{tabular}{|c|c|c|c|c|c|c|c|c|c|c|}
\hline $\begin{array}{c}\text { WEKGHT } \\
\mathrm{H}\end{array}$ & A-101 & A-103 & $A-106$ & $A X-101$ & AX-103 & B-104 & B-105 & B-106 & B-108 & $B X-109$ \\
\hline $\begin{array}{l}H \\
M\end{array}$ & $H$ & $\mathrm{H}$ & $M$ & $\begin{array}{l}\mathrm{H} \\
\mathrm{M}\end{array}$ & $\begin{array}{l}M \\
M\end{array}$ & $M$ & H & $\mathrm{H}$ & $\mathbf{M}$ & \\
\hline M & & & & & & & & & & $\mathrm{H}$ \\
\hline M & $M$ & $\mathbf{L}$ & $\mathrm{L}$ & $M$ & $\mathbf{L}$ & $M$ & $\mathbf{L}$ & $\mathrm{L}$ & $L$ & L \\
\hline L & $H$ & $\mathbf{M}$ & $H$ & $\mathbf{H}$ & $\mathrm{H}$ & $\mathrm{L}$ & $\mathbf{M}$ & $\mathbf{H}$ & $\mathbf{M}$ & $M$ \\
\hline
\end{tabular}

$\begin{array}{ccccccccccc}A-101 & A-103 & A-106 & A X-101 & A X-103 & B-104 & B-105 & B-106 & B-108 & B X-109 \\ 0 & 0 & 0 & 0 & 0 & 0 & 0 & 0 & 0 & 0 \\ 25 & 25 & 15 & 25 & 15 & 15 & 25 & 25 & 15 & 0 \\ 0 & 0 & 0 & 9 & 9 & 0 & 0 & 0 & 0 & 0 \\ 0 & 0 & 0 & 0 & 0 & 0 & 0 & 0 & 0 & 15 \\ 9 & 0 & 0 & 9 & 0 & 9 & 0 & 0 & 0 & 0 \\ 5 & 3 & 5 & 5 & 5 & 0 & 3 & 5 & 3 & 3 \\ 39 & 28 & 20 & 48 & 29 & 24 & 28 & 30 & 18 & 18 \\ 56 & 40 & 29 & 69 & 41 & 34 & 40 & 43 & 26 & 26\end{array}$

\begin{tabular}{|c|c|c|c|c|c|c|c|c|c|c|}
\hline $\begin{array}{c}\text { WEIGHT } \\
H\end{array}$ & $8 \times-110$ & $B X-112$ & $B Y-104$ & BY-105 & $B Y-106$ & BY-107 & $B Y-108$ & $B Y-110$ & $c-102$ & C-104 \\
\hline $\mathrm{H}$ & $M$ & $M$ & $\mathrm{H}$ & $\mathrm{H}$ & H & $\mathrm{H}$ & $M$ & H & & \\
\hline$M$ & & & & & & & & & H & $H$ \\
\hline$M$ & & & & & & $M$ & & & $M$ & \\
\hline$M$ & $M$ & $M$ & $M$ & $\mathbf{M}$ & $M$ & $\mathbf{L}$ & $\mathbf{M}$ & $M$ & M & $M$ \\
\hline L & $M$ & $M$ & $\mathrm{~L}$ & $M$ & $M$ & $\mathrm{H}$ & $\mathrm{H}$ & H & $\mathrm{L}$ & L \\
\hline
\end{tabular}

$\begin{array}{ccccccccccc}B X-110 & B X-112 & B Y-104 & B Y-105 & B Y-106 & B Y-107 & B Y-108 & B Y-110 & C-102 & \text { C-104 } \\ 0 & 0 & 0 & 0 & 0 & 0 & 0 & 0 & 0 & 0 \\ 15 & 15 & 25 & 25 & 25 & 25 & 15 & 25 & 0 & 0 \\ 0 & 0 & 0 & 0 & 0 & 0 & 0 & 0 & 15 & 15 \\ 0 & 0 & 0 & 0 & 0 & 9 & 0 & 0 & 9 & 0 \\ 9 & 9 & 9 & 9 & 9 & 0 & 9 & 9 & 9 & 9 \\ 3 & 3 & 0 & 3 & 3 & 5 & 5 & 5 & 0 & 0 \\ 27 & 27 & 34 & 37 & 37 & 39 & 29 & 39 & 33 & 24 \\ 39 & 39 & 49 & 53 & 53 & 56 & 41 & 56 & 47 & 34\end{array}$




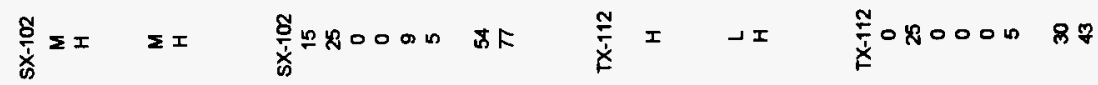

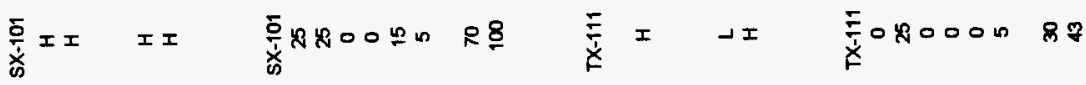

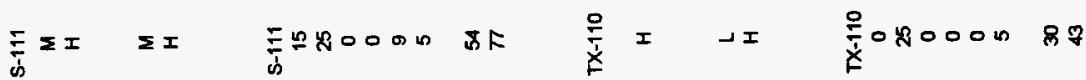

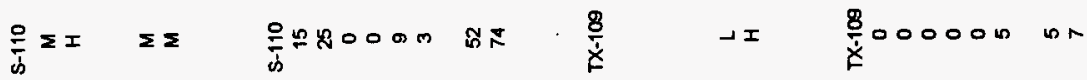

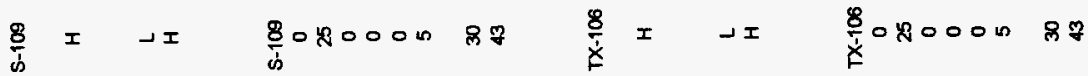

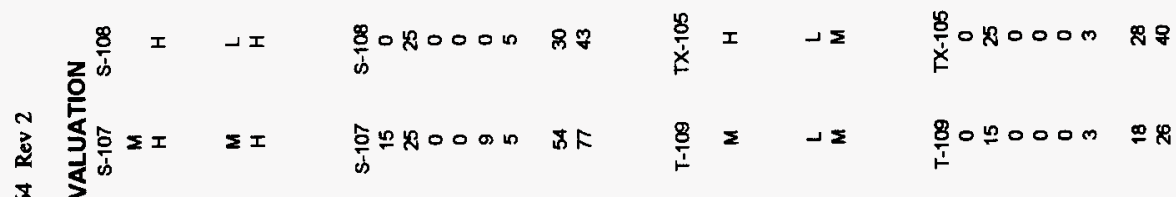
范 岁家 $1 \quad-x \quad \frac{8}{5}$

$\frac{8}{5} 04000087$ $\frac{8}{i} \Sigma \quad-\Sigma \quad \frac{8}{i} 00000 \%$

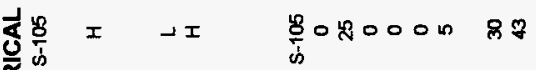

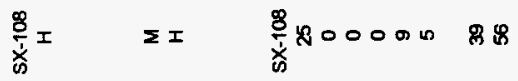

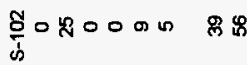

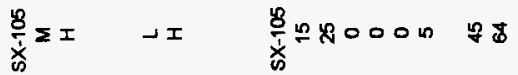

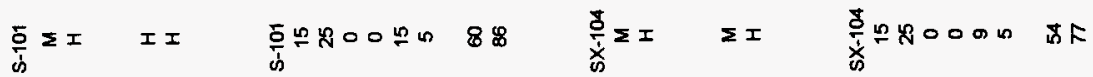

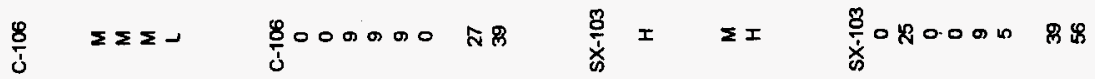
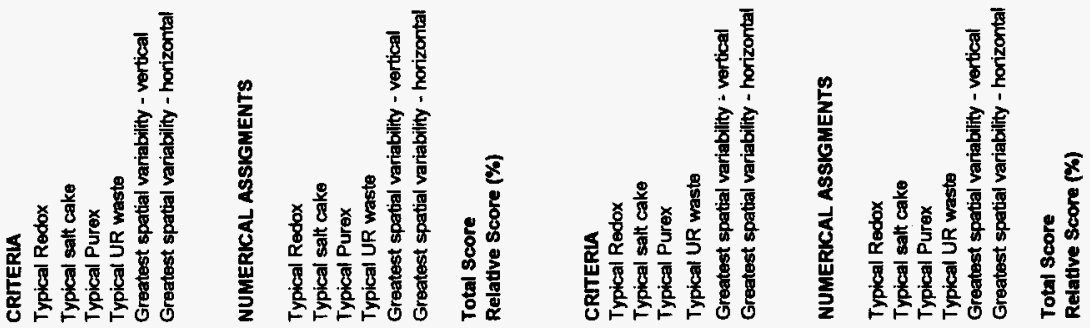
WHC-SD-WM-TA-164 Rev 2

\section{CRITERIA}

Typical Redox

Typical salt cake

Typical Purex

Typical UR waste

Greatest spatial variability - vertical

Greatest spatial variability - horizontal

\section{NUMERICAL ASSIGMENTS}

Typical Redox

Typical salt cake

Typical Purex

Typical UR wasto

Greatest spatial variability - vertical

Greatest spatial variability - horizontal

Total score

Relattve score $(\%)$

\section{CRITERIA}

Typical Redox

Typical salt cake

Typical Purex

Typical UR waste

Greatest spatial variabifity - vertical

Greatest spatial variability - horizontal

\section{NUMERICAL ASSIGMENTS}

\section{Typical Redox}

Typical salt cake

Typical Purex

Typical UR waste

Greatest spatial variability - vertical

Greatest spatial variability - horizontal

Total score

Relattve score (\%)

\section{HISTORICAL MODEL EVALUATION
$T x-113 \quad T X-114 \quad T X-115 \quad T X-116 \quad T X-117 \quad T X-118 \quad T Y-105$}

$\begin{array}{lllll}\text { U-102 } & \text { U-105 } & \text { U-106 } & \text { U-107 } & \text { U-108 }\end{array}$

H H

H

H

$\mathbf{H}$
$\mathbf{M}$

$\begin{array}{lll}M & M & L \\ H & H & H\end{array}$

$\begin{array}{ll}\mathrm{L} & \mathrm{M} \\ \mathrm{H} & \mathrm{H}\end{array}$

$\begin{array}{cccc}\text { TX-113 } & \text { TX-114 } & \text { TX-115 } & \text { TX } \\ 0 & 0 & 0 & \\ 25 & 25 & 25 & \\ 0 & 0 & 0 & \\ 0 & 0 & 0 & \\ 9 & 9 & 0 \\ 5 & 5 & 5 & \\ 39 & 39 & 30 & \\ 56 & 56 & 43 & \end{array}$

U-109 U-111

H $\quad$ M

$\begin{array}{ll}M & M \\ M & H\end{array}$

$\begin{array}{cc}U-109 & U-111 \\ 0 & 0 \\ 25 & 15 \\ 0 & 0 \\ 0 & 0 \\ 9 & 9 \\ 3 & 5 \\ 37 & 29 \\ 53 & 41\end{array}$


WHC-SD-WM-TA-164 Rev. 2

This page intentionally left blank. 
WHC-SD-WM-TA-164 Rev. 2

\section{APPENDIX D}

INDIVIDUAL ISSUE PRIORITIES

D-1 
WHC-SD-WM-TA-164 Rev. 2

This page intentionally left blank. 
WHC-SD-WM-TA-164 Rev 2

\section{INDIVIDUAL ISSUE PRIORITIES}

\begin{tabular}{|c|c|c|c|c|c|c|c|c|c|c|}
\hline ISSUE TYPE & ISSUES & A-101 & A-102 & A-103 & A-104 & A-105 & A-106 & AX-101 & AX-102 & $A X-103$ \\
\hline \multirow[t]{6}{*}{ SAFETY: } & Flammable Gas & 87 & $n / a$ & 45 & $n / a$ & $n / a$ & $n / a$ & $\mathrm{n} / \mathrm{a}$ & $n / a$ & $n / a$ \\
\hline & OHOHOHWHOHOHOS & 6 & 86 & 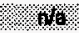 & Wo & 10 & (x) & ato & 6 & \% \\
\hline & Safety Screening & 80 & 87 & 80 & 53 & 53 & 87 & 80 & 84 & 96 \\
\hline & Whp & 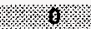 & (6) & B & 6 & 6 & Who & 8 & 好 & 6. \\
\hline & Vapor Space Phenomenology & n/a & $n / a$ & $n / a$ & na & $\mathrm{n} / \mathrm{a}$ & $n / a$ & $n / a$ & n/a & n/a \\
\hline & 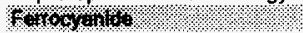 & $\alpha$ & 8 & 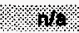 & \% & 14 & me & \% & \% & of \\
\hline \multirow[t]{4}{*}{ DISPOSAL: } & Privatization & $\mathrm{n} / \mathrm{a}$ & $\mathrm{n} / \mathrm{a}$ & $\mathrm{n} / \mathrm{a}$ & $\mathrm{n} / \mathrm{a}$ & $\mathrm{n} / \mathrm{a}$ & $\mathrm{n} / \mathrm{a}$ & $\mathrm{n} / \mathrm{a}$ & $\mathrm{n} / \mathrm{a}$ & $\mathrm{n} / \mathrm{a}$ \\
\hline & 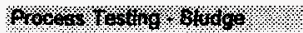 & 20 & 46 & 40 & 14 & Wo & 40 & $1 \%$ & $\%$ & $4 \%$ \\
\hline & Process Testing - Supernatant & n/a & n/a & $n / a$ & $n / a$ & $n / a$ & $n / a$ & $\mathrm{n} / \mathrm{a}$ & $n / a$ & $n / a$ \\
\hline & Row & ah & $W$ & 10 & mo & war & Wh & Ma & \% & ox \\
\hline CHARACTERIZATION: & Historical Model Evaluation & 56 & $\mathrm{n} / \mathrm{a}$ & 40 & $\mathrm{n} / \mathrm{a}$ & $\mathrm{n} / \mathrm{a}$ & 29 & 69 & n/a & 41 \\
\hline ISSUE TYPE & ISSUES & $A X-104$ & B-101 & B-102 & B-103 & $B-104$ & $B-105$ & $B-106$ & B-107 & B-108 \\
\hline \multirow[t]{6}{*}{ SAFETY: } & Flammable Gas & $n / a$ & $n / a$ & $n / a$ & n/a & $n / a$ & $n / a$ & $n / a$ & $n / a$ & $n / a$ \\
\hline & 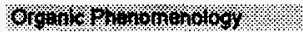 & (2) & $x+$ & 40 & 6 & 18 & of & wit & $x$ & 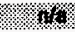 \\
\hline & Safety Screening & 49 & 42 & 42 & 42 & 16 & 42 & 25 & 33 & 42 \\
\hline & 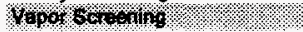 & 1 & 8 & - 10 & 100. & \% & $8 \%$ & \% & 16 & o \\
\hline & Vapor Space Phenomenology & $n / a$ & $n / a$ & $\mathrm{n} / \mathrm{a}$ & 50 & $\mathrm{n} / \mathrm{a}$ & $n / a$ & $n / a$ & $\mathrm{n} / \mathrm{a}$ & $n / a$ \\
\hline & $8 \%$ of $14=2$ & $1+$ & 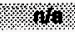 & xis & 40 & Wh & SW & \% & 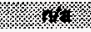 & $4 \%$ \\
\hline \multirow[t]{4}{*}{ DISPOSAL: } & Privatization & $\mathrm{n} / \mathrm{a}$ & $\mathrm{n} / \mathrm{a}$ & $n / a$ & $\mathrm{n} / \mathrm{a}$ & $\mathrm{n} / \mathrm{a}$ & n/a & $n / a$ & $n / a$ & $n / a$ \\
\hline & 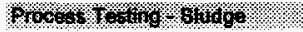 & $M$ & 48 & mo & 0 & 婪 & (x) & 要 & ox & (1) \\
\hline & Process Testing - Supernatant & $\mathrm{n} / \mathrm{a}$ & n/a & n/a & n/a & $n / a$ & $\mathrm{n} / \mathrm{a}$ & $\mathbf{n a}$ & $\mathrm{n} / \mathrm{a}$ & $\mathrm{n} / \mathrm{a}$ \\
\hline & 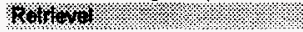 & 68 & M & 10 & 8) & 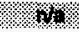 & (1) & 1) & 20 & 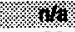 \\
\hline CHARACTERIZATION: & Historical Model Evaluation & n/a & $n / a$ & na & $\mathrm{n} / \mathrm{a}$ & 34 & 40 & 43 & $\mathrm{n} / \mathrm{a}$ & 26 \\
\hline
\end{tabular}

$\mathrm{n} / \mathrm{a}=$ currently tank does not have this issue and not in scope 
WHC-SD-WM-TA-164 Rev 2

INDIMDUAL ISSUE PRIORITIES

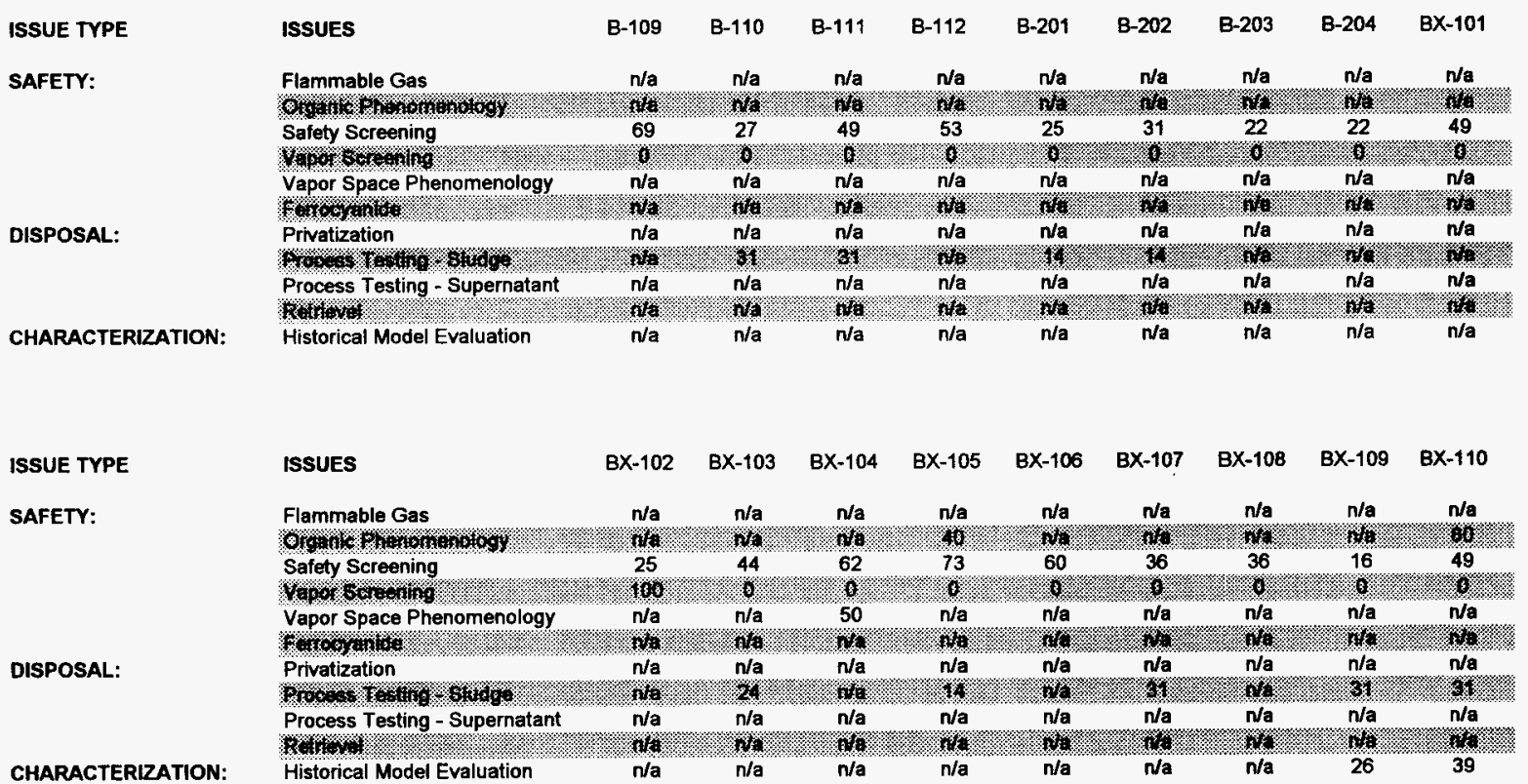

$\mathrm{n} / \mathrm{a}=$ currently tank does not have this issue and not in scope 
WHC-SD-WM-TA-164 Rev 2

\section{INDIVDUAL ISSUE PRIORITIES}

\begin{tabular}{|c|c|c|c|c|c|c|c|c|c|c|}
\hline ISSUE TYPE & ISSUES & BX-111 & $8 X-112$ & BY-101 & BY-102 & $B Y-103$ & BY-104 & BY-105 & BY-106 & BY-107 \\
\hline \multirow[t]{6}{*}{ SAFETY: } & Flammable Gas & $n / a$ & n/a & 53 & $n / a$ & n/a & $\mathrm{n} / \mathrm{a}$ & na & $\mathrm{n} / \mathrm{a}$ & $\mathrm{Na}$ \\
\hline & 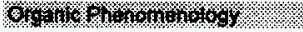 & mo & mals & Ho & of & 34 & 4 & \% & x. & mo \\
\hline & Safety Screening & 80 & 62 & 89 & 85 & 69 & 80 & 89 & 100 & 80 \\
\hline & 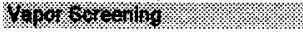 & $16 x$ & \%o & 60 & 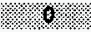 & 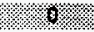 & ox & 8 & to & 縟 \\
\hline & Vapor Space Phenomenology & $n / a$ & n/a & n/a & n/a & n/a & n/a & n/a & $\mathrm{n} / \mathrm{a}$ & $n / a$ \\
\hline & 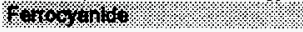 & Ho & Hax & \%o & 34 & 18 & \% & $2 \%$ & $\%$ & $\%$ \\
\hline \multirow[t]{4}{*}{ DISPOSAL: } & Privatization & n/a & n/a & n/a & $n / a$ & $\mathrm{n} / \mathrm{a}$ & $\mathrm{n} / \mathrm{a}$ & $n / a$ & $\mathrm{n} / \mathrm{a}$ & na \\
\hline & 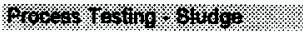 & 10 & 10 & Wa & Wo & ma & $8 \%$ & so & \% & 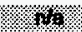 \\
\hline & Process Testing - Supernatant & n/a & $n / a$ & n/a & n/a & n/a & $n / a$ & n/a & $\mathrm{n} / \mathrm{a}$ & n/a \\
\hline & $\mathrm{Hox} / \mathrm{\alpha}$ & wa & no & 1010 & ord & wa & $10 \%$ & $2 \%$ & Wro & 84 \\
\hline CHARACTERIZATION: & Historical Model Evaluation & $\mathrm{n} / \mathrm{a}$ & 39 & n/a & $n / a$ & $n / a$ & 49 & 53 & 53 & 56 \\
\hline ISSUE TYPE & ISSUES & $B Y-108$ & $B Y-109$ & $B Y-110$ & $B Y-111$ & $B Y-112$ & $\mathrm{c}-101$ & $\mathrm{C}-102$ & $\mathrm{c}-103$ & C-104 \\
\hline \multirow[t]{6}{*}{ SAFETY: } & Flammable Gas & n/a & 45 & $n / a$ & $n / a$ & $n / \mathbf{a}$ & $n / a$ & n/a & n/a & $n / a$ \\
\hline & 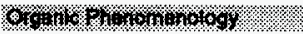 & 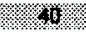 & Wh & X18. & 46 & $x$ & $1 \%$ & 0 & 㜻 & \% \\
\hline & Safety Screening & 53 & 82 & 80 & 80 & 64 & 25 & 33 & 62 & 87 \\
\hline & 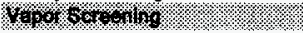 & 16- & $8 \%$ & 16. & 0 & 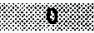 & 0 & 6 & (6) & S \\
\hline & Vapor Space Phenomenology & 50 & $n / a$ & $n / a$ & $n / a$ & $n / a$ & $\mathrm{n} / \mathrm{a}$ & n/a & $n / a$ & $n / a$ \\
\hline & 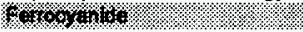 & mo & Wha & 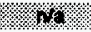 & \% & 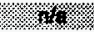 & 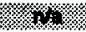 & 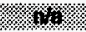 & $\%$ & \%x. \\
\hline \multirow[t]{4}{*}{ DISPOSAL: } & Privatization & $\mathrm{n} / \mathrm{a}$ & $\mathrm{n} / \mathrm{a}$ & $n / a$ & $n / a$ & $n / a$ & $n / a$ & $\mathrm{n} / \mathrm{a}$ & $\mathrm{n} / \mathrm{a}$ & na \\
\hline & 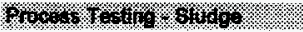 & gat & Wh & 67 & $\%$ & 10 & $\%$ & Ka & $x$ & \% \\
\hline & Process Testing - Supernatant & $\mathbf{n} / \mathbf{a}$ & $n / a$ & $n / a$ & $n / a$ & $\mathrm{n} / \mathrm{a}$ & $n / a$ & $n / a$ & $n / a$ & $\mathrm{n} / \mathrm{a}$ \\
\hline & 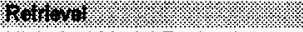 & (6) & \%o & 26 & 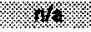 & 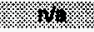 & \% & $x$ & 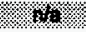 & 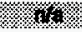 \\
\hline CHARACTERIZATION: & Historical Model Evaluation & 41 & n/a & 56 & $\mathrm{n} / \mathrm{a}$ & $n / a$ & $n / a$ & 47 & $\mathrm{n} / \mathrm{a}$ & 34 \\
\hline
\end{tabular}

$\mathrm{n} / \mathrm{a}=$ currently tank does not have this issue and not in scope 
WHC-SD-WM-TA-164 Rev 2

\section{INDIMDUAL ISSUE PRIORITIES}

\begin{tabular}{|c|c|c|c|c|c|c|c|c|c|c|}
\hline ISSUE TYPE & ISSUES & C-105 & C-106 & C-107 & C-108 & C-109 & $C-110$ & C-111 & $\mathrm{C}-112$ & C-201 \\
\hline \multirow[t]{6}{*}{ SAFETY: } & Flammable Gas & $n / a$ & $n / a$ & $n / a$ & n/a & $n / a$ & $n / a$ & $\mathrm{n} / \mathrm{a}$ & $\mathrm{n} / \mathbf{a}$ & $n / a$ \\
\hline & 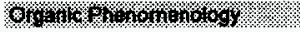 & Wh & $\%$ & 㩐3 & ox & $x+$ & 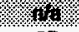 & 42 & (2) & Hix \\
\hline & Safety Screening & 16 & 55 & 35 & 25 & 22 & 27 & 25 & 16 & 25 \\
\hline & Wpos & Xo & 0 & xa & o & 0 & 6 & \% & 3 & 8 \\
\hline & Vapor Space Phenomenology & $n / a$ & $n / a$ & 50 & $n / a$ & $n / a$ & $\mathrm{n} / \mathrm{a}$ & $\mathrm{n} / \mathrm{a}$ & $\mathrm{n} / \mathrm{a}$ & $\mathbf{n} / \mathbf{a}$ \\
\hline & Hor & m & Ho & 40 & 10 & \%क & res & 80 & (m) & 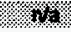 \\
\hline \multirow[t]{4}{*}{ DISPOSAL: } & Privatization & $\mathrm{n} / \mathrm{a}$ & 62 & $\mathrm{n} / \mathrm{a}$ & $n / a$ & $n / a$ & na & $n / a$ & $\mathrm{n} / \mathrm{a}$ & $n / a$ \\
\hline & 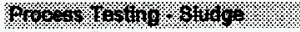 & 48 & ota & 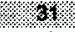 & 48 & 84 & 148 & \%) & 84 & $\%$ \\
\hline & Process Testing - Supernatant & n/a & $\mathrm{n} / \mathrm{a}$ & $\mathrm{n} / \mathrm{a}$ & $n / a$ & $\mathrm{n} / \mathrm{a}$ & n/a & $\mathrm{n} / \mathrm{a}$ & $\mathrm{n} / \mathrm{a}$ & $\mathrm{n} / \mathrm{a}$ \\
\hline & Hour & Wh & K60 & 1) & Wha & 34 & 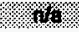 & $x<$ & 44 & m \\
\hline CHARACTERIZATION: & Historical Model Evaluation & $\mathrm{n} / \mathrm{a}$ & 39 & $\mathrm{n} / \mathrm{a}$ & $n / a$ & $\mathrm{n} / \mathrm{a}$ & $\mathrm{n} / \mathrm{a}$ & $\mathrm{n} / \mathrm{a}$ & $\mathrm{n} / \mathbf{a}$ & $\mathrm{n} / \mathrm{a}$ \\
\hline ISSUE TYPE & ISSUES & C-202 & C-203 & C-204 & $5-101$ & S-102 & S-103 & S-104 & $S-105$ & $S-106$ \\
\hline \multirow[t]{6}{*}{ SAFETY: } & Flammable Gas & $n / a$ & n/a & $n / a$ & $n / a$ & $n / a$ & $\mathrm{n} / \mathrm{a}$ & $\mathbf{n} / \mathbf{a}$ & $\mathrm{n} / \mathrm{a}$ & 87 \\
\hline & 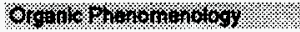 & 80 & Na & \% & xag & 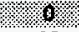 & 40 & \% & $4 \%$ & 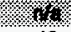 \\
\hline & Safety Screening & 25 & 36 & 22 & 69 & 62 & 53 & 53 & 35 & 42 \\
\hline & 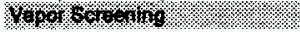 & g & xo & ga & 6 & 6 & get & $\%$ & 眇 & 6 \\
\hline & Vapor Space Phenomenology & $\mathrm{n} / \mathrm{a}$ & n/a & $n / a$ & na & 100 & $\mathrm{n} / \mathrm{a}$ & $\mathrm{n} / \mathrm{a}$ & $\mathrm{n} / \mathrm{a}$ & $\mathrm{n} / \mathrm{a}$ \\
\hline & H $1 \% \% 4 h \%$ \% & $4 \%$ & \% & W1 & w & 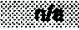 & M & \% & 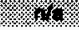 & $\%$ \\
\hline \multirow[t]{4}{*}{ DISPOSAL: } & Privatization & $\mathrm{n} / \mathrm{a}$ & $\mathrm{n} / \mathrm{a}$ & $n / a$ & n/a & $n / a$ & $\mathrm{n} / \mathrm{a}$ & $n / a$ & $\mathrm{n} / \mathrm{a}$ & $\mathrm{n} / \mathrm{a}$ \\
\hline & 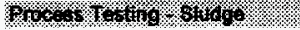 & 16 & ry & $x+1$ & 80. & Ho & Wo & Kols & 34 & No \\
\hline & Process Testing - Supernatant & $\mathrm{na}$ & $\mathrm{n} / \mathrm{a}$ & $n / a$ & $\mathrm{n} / \mathrm{a}$ & $\mathrm{n} / \mathbf{a}$ & $\mathbf{n} / \mathbf{a}$ & $\mathrm{n} / \mathbf{a}$ & $\mathrm{n} / \mathrm{a}$ & $\mathrm{n} / \mathrm{a}$ \\
\hline & $61+x$ & \% & mo & \% & 40 & 30 & 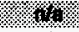 & 18) & 30 & $\$$ \\
\hline CHARACTERIZATION: & Historical Model Evaluation & $\mathrm{n} / \mathrm{a}$ & $\mathrm{n} / \mathrm{a}$ & $n / a$ & 86 & 56 & $n / a$ & $n / a$ & 43 & 43 \\
\hline
\end{tabular}

$n / a=$ currently tank does not have this issue and not in scope 


\section{WHC-SD-WM-TA-164 Rev 2}

\section{INDIMDUAL ISSUE PRIORITIES}

ISSUE TYPE

SAFETY:

DISPOSAL

CHARACTERIZATION:

ISSUE TYPE

SAFETY:

DISPOSAL:

CHARACTERIZATION:

ISSUES

S-107

S-108

S-109

S-110

S-111

S-112

sX-101 sX-102

sx-103

\begin{tabular}{|c|c|c|c|c|c|c|c|c|c|}
\hline Flammable Gas & $\mathrm{n} / \mathrm{a}$ & $n / a$ & $\mathrm{n} / \mathrm{a}$ & n/a & $\mathbf{n} / \mathbf{a}$ & 45 & $\mathrm{n} / \mathrm{a}$ & $\mathrm{n} / \mathrm{a}$ & $\mathrm{n} / \mathrm{a}$ \\
\hline 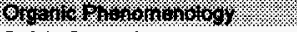 & \% & $1 \%$ & 64 & 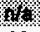 & 6 & $1 \%$ & \% & 算 & 8 \\
\hline Safety Screening & 69 & 25 & 31 & 69 & 69 & 31 & 89 & 96 & 96 \\
\hline 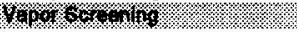 & 6 & 的高 & $x 6$ & 80 & 8 & 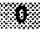 & \%o & \% & 6 \\
\hline Vapor Space Phenomenology & $\mathrm{n} / \mathrm{a}$ & $n / a$ & $n / a$ & $\mathrm{n} / \mathrm{a}$ & $n / a$ & $\mathrm{n} / \mathrm{a}$ & $\mathrm{n} / \mathrm{a}$ & $n / a$ & $n / a$ \\
\hline 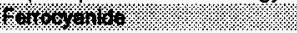 & mo & 1/4 & \% & 67 & 10 & $m$ & oto & $\%$ & \% \\
\hline Privatization & $\mathrm{n} / \mathrm{a}$ & $\mathrm{n} / \mathrm{a}$ & $\mathrm{n} / \mathrm{a}$ & $\mathrm{n} / \mathrm{a}$ & $\mathrm{n} / \mathrm{a}$ & $\mathrm{n} / \mathrm{a}$ & $n / a$ & $\mathrm{n} / \mathrm{a}$ & $\mathrm{n} / \mathrm{a}$ \\
\hline 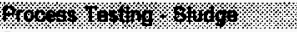 & 40 & 16 & \% & 4 & 10\% & $\sqrt{3}$ & 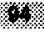 & 48 & $x$ \\
\hline Process Testing - Supernatant & $\mathrm{n} / \mathrm{a}$ & $\mathrm{n} / \mathrm{a}$ & $\mathrm{n} / \mathrm{a}$ & n/a & $\mathrm{n} / \mathrm{a}$ & n/a & n/a & $n / a$ & $n / 8$ \\
\hline 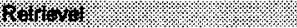 & (na & 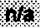 & $\%$ & $6 \%$ & Ha & $x$ & $x=$ & 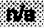 & 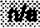 \\
\hline Historical Model Evaluation & 77 & 43 & 43 & 74 & 77 & $\mathrm{n} / \mathrm{a}$ & 100 & 77 & 56 \\
\hline
\end{tabular}

\section{ISSUES}

sX-104 sX-105

SX-106 SX-107

sX-108

sx-109

SX-110

SX-111

SX-112

\section{Flammable Gas}

$\frac{n / a}{78}$

\section{Safety Screening}

$78 \quad 78$

$\mathrm{n} / \mathrm{a} \quad 45$

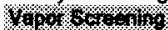

n/a

$\mathrm{nda} \quad \mathrm{n} / \mathrm{a}$

$n / a \quad n / a \quad n / a \quad n / a$

n/a n/a n/a n/a

5353

64 \%

$53 \quad 53$

$53 \quad 53$

Vapor Space Phenomenology

Privatization

168 \%

8 \%

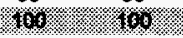

$\mathrm{n} / \mathrm{a} \quad \mathrm{n} / \mathrm{a} \quad \mathrm{n} / \mathrm{a} \quad \mathrm{n} / \mathrm{a} \quad \mathrm{n} / \mathrm{a} \quad \mathrm{n} / \mathrm{a} \quad \mathrm{n} / \mathrm{a} \quad \mathrm{n} / \mathrm{a} \quad \mathrm{n} / \mathrm{a}$

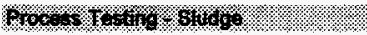

Process Testing - Supernatant n/a

$\mathrm{n} / \mathrm{a} \quad \mathrm{n} / \mathrm{a}$

$\begin{array}{lllllll}n / a & n / a & n / a & n / a & n / a & n / a & n / a\end{array}$

Historical Model Evaluation

$77 \quad 64$

6.

$\mathrm{n} / \mathrm{a} \quad \mathrm{N} / \mathrm{a}$

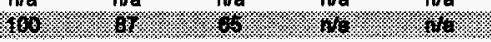

n/a n/a n n/a n/a n/a

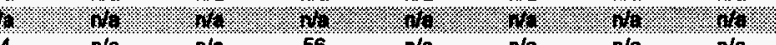

$\mathrm{n} / \mathrm{a}=$ currently tank does not have this issue and not in scope 
WHC-SD-WM-TA-164 Rev 2

\section{INDIMDUAL ISSUE PRIORITIES}

\begin{tabular}{|c|c|c|c|c|c|c|c|c|c|c|}
\hline ISSUE TYPE & ISSUES & $S x-113$ & $s x-114$ & $s \times-115$ & $T-101$ & T-102 & $T-103$ & $T-104$ & $T-105$ & $T-106$ \\
\hline \multirow[t]{6}{*}{ SAFETY: } & Flammable Gas & $n / a$ & $n / a$ & $n / a$ & $n / a$ & $n / a$ & $n / a$ & $\mathrm{n} / \mathbf{a}$ & n/a & n/a \\
\hline & OH, & 110 & 10 & 810 & \%x & $10 \%$ & 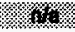 & $3 \%$ & \%) & 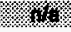 \\
\hline & Safety Screening & 25 & 53 & 53 & 49 & 16 & 22 & 55 & 33 & 16 \\
\hline & 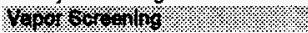 & 6 & 100 & 鴊 & $16 \%$ & 6) & 8 & 6. & 6 & sk \\
\hline & Vapor Space Phenomenology & $n / a$ & $\mathrm{n} / \mathrm{a}$ & $\mathrm{n} / \mathrm{a}$ & $n / a$ & $\mathrm{n} / \mathrm{a}$ & $\mathrm{n} / \mathrm{a}$ & $\mathrm{n} / \mathrm{a}$ & n/a & $n / a$ \\
\hline & Btoroshot & 14 & nox & $\%$ & 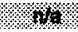 & $10 \%$ & nox & wo & $6 \%$ & 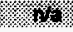 \\
\hline \multirow[t]{4}{*}{ DISPOSAL: } & Privatization & $\mathrm{n} / \mathrm{a}$ & n/a & $n / a$ & $\mathrm{n} / \mathrm{a}$ & $n / a$ & $\mathrm{n} / \mathrm{a}$ & $\mathrm{n} / \mathrm{a}$ & na & n/a \\
\hline & 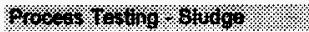 & 40 & 140 & (1) & mo & 14\% & 8 & 48 & \% & $8 x$ \\
\hline & Process Testing - Supernatant & $n / a$ & $\mathrm{n} / \mathrm{a}$ & $n / a$ & $n / a$ & $n / a$ & Na & $n / a$ & $\mathrm{n} / \mathrm{a}$ & $n / a$ \\
\hline & 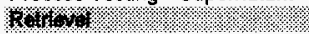 & wata & $8 \times$ & 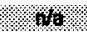 & 10 & W & 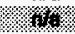 & $3 \%$ & $x+$ & $3 \%$ \\
\hline CHARACTERIZATION: & Historical Model Evaluation & $n / a$ & n/a & n/a & $\mathrm{n} / \mathrm{a}$ & $\mathrm{n} / \mathrm{a}$ & $n / a$ & $\mathrm{n} / \mathrm{a}$ & $\mathrm{n} / \mathrm{a}$ & $\mathrm{n} / \mathrm{a}$ \\
\hline ISSUE TYPE & ISSUES & $T-107$ & $T-108$ & $T-109$ & $T-110$ & $\mathrm{~T}-111$ & $\mathrm{~T}-112$ & $\mathrm{~T}-201$ & $\mathrm{~T}-202$ & $\mathrm{~T}-203$ \\
\hline \multirow[t]{6}{*}{ SAFETY: } & Flammable Gas & $n / a$ & $n / a$ & n/a & n/a & $\mathrm{n} / \mathrm{a}$ & $n / a$ & n/a & $\mathrm{n} / \mathrm{a}$ & $n / a$ \\
\hline & 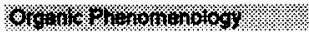 & Ho & 1) & $6 \%$ & 16 & 80 & 8 - & $x_{0}$ & w1 & 籁 \\
\hline & Safety Screening & 27 & 22 & 25 & 36 & 27 & 27 & 25 & 25 & 16 \\
\hline & 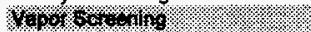 & \% & 10 & xa & 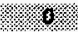 & o. & 譣 & $8 / 3$ & tor & 46 \\
\hline & Vapor Space Phenomenology & n/a & $\mathrm{n} / \mathrm{a}$ & n/a & $n / a$ & $n / a$ & n/a & $\mathrm{n} / \mathrm{a}$ & n/a & n/a \\
\hline & Whoornto & 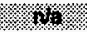 & ato & $1 \%$ & H & 146 & 5 & \% & $1 \%$ & $\%$ \\
\hline \multirow[t]{4}{*}{ DISPOSAL: } & Privatization & $n / a$ & $n / a$ & $\mathrm{n} / \mathrm{a}$ & $\mathrm{n} / \mathrm{a}$ & na & $\mathbf{n} / \mathbf{8}$ & $n / a$ & n/a & $\mathrm{n} / \mathrm{a}$ \\
\hline & 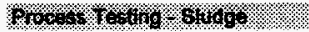 & \% & ox & \% & rat & K/ & 4 玨 & $4 \%$ & 164 & 848 \\
\hline & Process Testing - Supernatant & $n / a$ & $\mathrm{n} / \mathrm{a}$ & $n / a$ & $n / a$ & $n / a$ & n/a & n/a & $n / a$ & n/a \\
\hline & 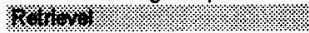 & m & 12 & of & (3) & 18 & 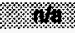 & 26 & 110. & 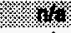 \\
\hline CHARACTERIZATION: & Historical Model Evaluation & $n / a$ & 26 & 26 & $\mathrm{n} / \mathrm{a}$ & n/a & n/a & $n / a$ & $\mathrm{n} / \mathrm{a}$ & $\mathrm{n} / \mathrm{a}$ \\
\hline
\end{tabular}

$\mathrm{n} / \mathrm{a}=$ currently tank does not have this issue and not in scope 


\section{WHC-SD-WM-TA-164 Rev 2}

\section{INDIVDUAL ISSUE PRIORITIES}

ISSUE TYPE

SAFETY:

DISPOSAL:

CHARACTERIZATION:
ISSUES Flammable Gas Safety Screening

. W10. w

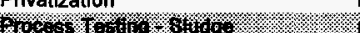
Process Testing - Supernatant n/a Y\%

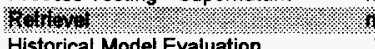

T-204
$T X-104$
TX-102 TX-103

TX-105

DISPOSAL:

CHARACTERIZATION:

\section{TX-109 TX-110 TX-111 TX-112 $\quad$ TX-113 $\quad$ TX-114 $\quad$ TX-115 $\quad$ TX-116 $\quad$ TX-117}

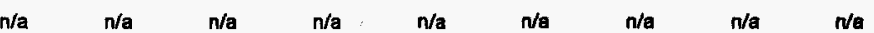

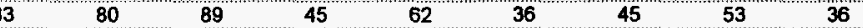

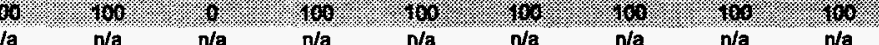
$\begin{array}{llllllll}n / a & n / a & n / a & n / a & n / a & n / a & n / a & n / a\end{array}$

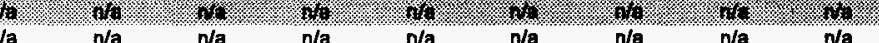

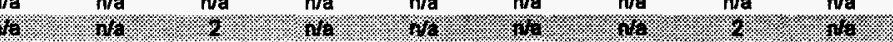
$\begin{array}{llllllll}n / a & n / a & n / a & n / a & n / a & n / a & n / a & n / a\end{array}$ 6.

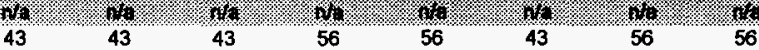

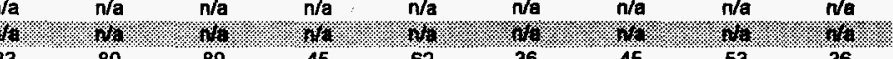

$\mathrm{n} / \mathrm{a}=$ currently tank does not have this issue and not in scope 
WHC-SD-WM-TA-164 Rev 2

INDIVIDUAL ISSUE PRIORITIES

ISSUE TYPE

SAFETY:

DISPOSAL:

CHARACTERIZATION:

ISSUE TYPE

SAFETY:

DISPOSAL:

CHARACTERIZATION:

ISSUES

TX-118 TY-101

TY-102 TY-103

TY-104

TY-105

TY-106

U-101

U-102

Flammable Gas

na

n/a $\quad n / a$

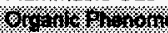

Safety Screening

$40 \%$ \%

Kofos

Na $\quad n / a$

n/a $\quad n / a$

$\mathrm{n} / \mathrm{a} \quad \mathrm{n} / \mathrm{a} \quad \mathrm{N} / \mathrm{a}$

Vapor Space Phenomentogy

1/. 8

$33 \quad 16$

16 27

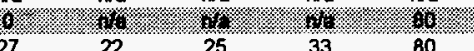

tortoon on $\%$. $\%$.

$\begin{array}{llll}\mathrm{Na} & \mathrm{n} / \mathrm{a} & \mathrm{n} / \mathrm{a} & 50\end{array}$

25

33 80

Privatization

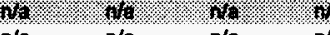

$\mathrm{n} / \mathrm{a}$

s.8.

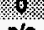

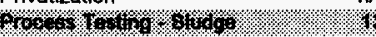

Process Testing - Supernatant

$n / a \quad n / a$

$\begin{array}{lllll}n / a & n / a & n / a & n / a & N a\end{array}$

row 1 \% .

$\mathrm{n} / \mathrm{a} \quad \mathrm{n} / \mathrm{a} \quad \mathrm{n} / \mathrm{a}$

-

.

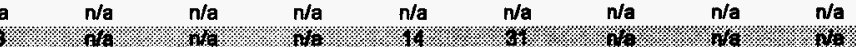

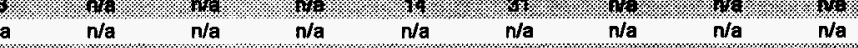

Historical Model Evaluation

69

$\mathrm{nu} / \mathrm{mo}$

$\mathrm{No} / \mathrm{H} / \mathrm{a} / \mathrm{m} / \mathrm{a}$

$6 \%$ m

$n / a \quad 29$

n/a

53

ISSUES

U-103

U-104

U-105

U-106

U-107

U-108

U-109

U-110

U-111

Flammable Gas

$73 \quad \mathrm{n} / \mathrm{a} \quad \mathrm{n}$

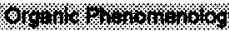

Safety Screening

and $x$; - oning

$69 \quad 25 \quad 7$

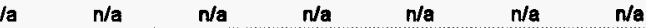

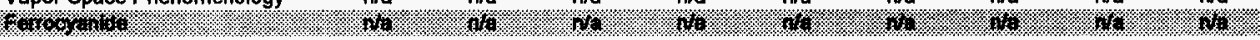

Privatization

$\mathrm{n} / \mathrm{a} \quad \mathrm{n} / \mathrm{a} \quad \mathrm{n} / \mathrm{a}$

$\mathrm{n} / \mathrm{a} \quad \mathrm{n} / \mathrm{a} \quad \mathrm{n} / \mathrm{a} \quad \mathrm{n} / \mathrm{a} \quad \mathrm{N} / \mathrm{a} \quad \mathrm{N} / \mathrm{a} \quad \mathrm{Na}$

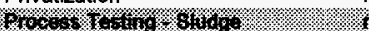

Process Testing - Supernatant

$\mathrm{n} / \mathrm{a} \quad \mathrm{n} / \mathrm{a} \quad \mathrm{n} / \mathrm{a}$

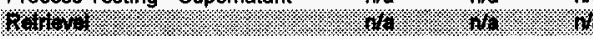

Historical Model Evaluation

n/a

n/a $\quad 53$

53 . 40

40.10

53

8

53

n/a n/a

Waxwa

Na

na

41

$\mathrm{n} / \mathrm{a}=$ currently tank does not have this issue and not in scope 
WHC-SD-WM-TA-164 Rev 2

\section{INDIVIDUAL ISSUE PRIORITIES}

ISSUE TYPE

SAFETY:

DISPOSAL:

CHARACTERIZATION:

ISSUE TYPE

SAFETY:

DISPOSAL:

CHARACTERIZATION:

\section{ISSUES}

U-112

U-201

U-202

U-203

U-204

AN-10

AN-102

AN-103

AN-104

Flammable Gas

$n / a$

Safety Screening

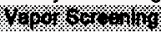

a

Vapor Space Phenomenology

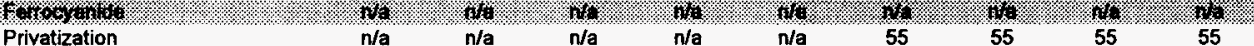

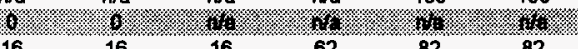

$\begin{array}{lllll}16 & 16 & 62 & 82 & 82\end{array}$

1616 \%

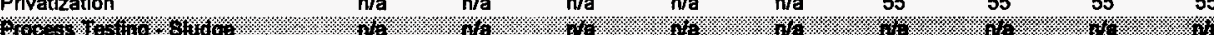

$\begin{array}{llllllllllllllll}\text { Process Testing - Supernatant } & n / a & n / a & n / a & n / a & n / a & n / a & 100 & n / a & 100\end{array}$

now

Historical Model Evaluation

$\begin{array}{llll}n / a & n / a & n / a & n / a\end{array}$

$\mathrm{n} / \mathrm{a} \quad \mathrm{n} / \mathrm{a}$

$\mathrm{n} / \mathrm{a}$

$\mathrm{n} / \mathrm{a}$

$\mathrm{n} / \mathrm{a}$

$\mathrm{n} / \mathrm{a}=$ currently tank does not have this issue and not in scope 
WHC-SD-WM-TA-164 Rev 2

\section{INDIVIDUAL ISSUE PRIORITIES}

ISSUE TYPE

SAFETY:

DISPOSAL:
ISSUES

Flammable Gas

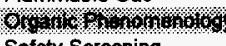

Safety Screening

Vepotow-ung

Vapor Space Phenomenology

Vapor Space Phenomenology n n/a

Privatization

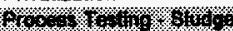

Process Testing - Supernatant

row

Historical Model Evaluation
AP-107 AP-108 AW-101 AW-102

AW-103

AW-104

AW-105

AW-106

AY-101

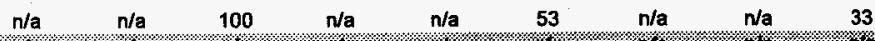

176 - 1 -

$\begin{array}{lllllllll}0 & 0 & 87 & 44 & 16 & 42 & 16 & 44 & 71\end{array}$

16. \%. \%

$n / a \quad n / a \quad n / a \quad n / a \quad n / a \quad n d a \quad n / a \quad n / a \quad n$

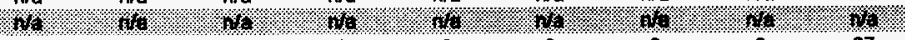

$\begin{array}{llllllll}27 & 0 & 100 & 0 & 0 & 0 & 0 & 0\end{array}$

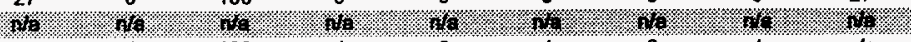

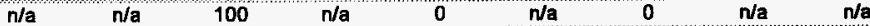

nda

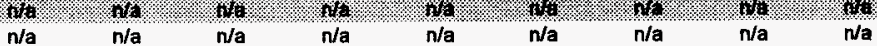

ISSUE TYPE

ISSUES

AY-102

AZ-101

AZ-102 SY-101

SY-102 SY-103

Flammable Gas

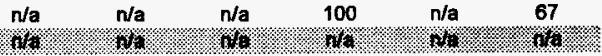

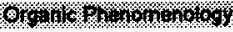

Safety Screening 16

44 H.

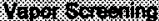

Vapor Space Phenomenology

\%

Privatization

16

16

$87 \quad 44$

$44 \quad 53$

DISPOSAL:

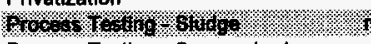

Process Testing - Supernatant

$n / a$

$4 w_{1}$.

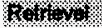

76.

$27 \cdots$

$0 \quad 27$

$\mathrm{n} / \mathrm{a}$

50

n/a n/a

CHARACTERIZATION: $\begin{array}{ll}108 & \\ \mathrm{n} / \mathrm{a} & \mathrm{n} / \mathrm{a}\end{array}$

\%oge

$\mathrm{n} / \mathrm{a}$

it

$\mathrm{n} / \mathrm{a}$

\%

$\mathrm{n} / \mathrm{a}=$ currently tank does not have this issue and not in scope 
WHC-SD-WM-TA-164 Rev. 2

APPENDIX E

ISSUE PRIORITIES AND WEIGHTS 
WHC-SD-WM-TA-164 Rev. 2

This page intentionally left blank. 
ISSUE PRIORITIES AND WEIGHTS

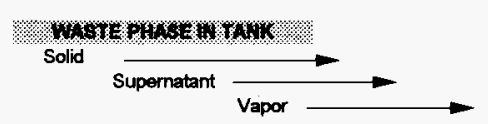

$\begin{array}{rrrrrr}A-101 & \text { A-102 } & \text { A-103 } & \text { A-104 } & \text { A-105 } & \text { A-106 } \\ \times & \times & \times & \times & x & \times \\ \times & \times & \times & x & x & x\end{array}$

\begin{tabular}{|c|c|c|c|c|c|}
\hline \multirow[t]{2}{*}{ 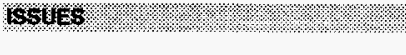 } & \multicolumn{3}{|c|}{ 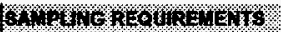 } & \multicolumn{2}{|c|}{ 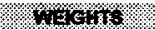 } \\
\hline & Solld & Liquid & Vapor & shift & Width \\
\hline Flammable Gas & $x$ & & & 0.1 & 10 \\
\hline 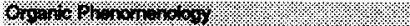 & $x$ & $x$ & & 03 & 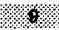 \\
\hline Safety Screening & $x$ & $x$ & & 0 & 6.5 \\
\hline 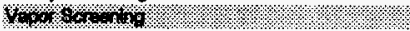 & & & $x$ & 要 & s. \\
\hline Vapor Space Phenomenology & & & $x$ & 1 & 3.5 \\
\hline $10 \% 4 \% 4 \%$ & $x$ & & & 80 & 0 \\
\hline Privatization & $x$ & $x$ & & 0.4 & 3.5 \\
\hline 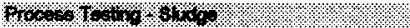 & x & W & & $\$ 8$ & 25 \\
\hline Process Testing - Supernatant & & $x$ & & 0.4 & 2.5 \\
\hline nown & x & $x$ & & $0 \%$ & \% \\
\hline Historical Model Evaluation & $x$ & & & 0.2 & 2 \\
\hline
\end{tabular}

\begin{tabular}{|c|c|c|c|c|c|}
\hline$a-101$ & A-102 & A-103 & A-104 & A-105 & A-106 \\
\hline 880 & 0 & 508 & 0 & 0 & 0 \\
\hline 800 & 10 & 34 & $\sigma$ & \% & 0 \\
\hline 520 & 567 & 520 & 343 & 343 & 567 \\
\hline 0 & 荻 & 20 & 8 & 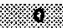 & 80,5 \\
\hline 0 & 0 & 0 & 0 & 0 & 0 \\
\hline 0 & 0 & $0 x$ & 8 & 0 & 0 \\
\hline 0 & 0 & 0 & 0 & 0 & 0 \\
\hline 100 & 0 & 6 & 0 & $\theta$ & 0 \\
\hline 0 & 0 & 0 & 0 & 0 & 0 \\
\hline$\theta$ & 0 & 8 & 0 & 0 & 6 \\
\hline 129 & 0 & 104 & 0 & 0 & 86 \\
\hline
\end{tabular}

\section{PRIORITIZATION - SOLID}

Total Score

Relattve Score \% (0 to 100)

A-101
2083

A-102

1377

A-10s

A-104

A-105

\section{A-108}

9

65

54

16

16

31

\section{PRIORITIZATION - SUPERNATANT}

Total Score

A-101

A-102

4-10s

A-104
0

A-105 A-108

Relative Score $\%(0$ to 100$)$

A-101

A-102

A-10

A-10-4

A-106

\section{Total Score}

Relattve Score \% (0 to 100) 
WHC-SD-WM-TA-164 Rev 2

\section{ISSUE PRIORITIES AND WEIGHTS}

\begin{tabular}{|c|c|c|c|c|c|c|c|c|c|c|c|}
\hline & $\begin{array}{c}A x-101 \\
x\end{array}$ & $\underset{x}{A X-102}$ & $\underset{x}{A X-103}$ & $\underset{x}{A X-104}$ & $\begin{array}{c}\text { B-101 } \\
x\end{array}$ & $\underset{x}{B-102}$ & $\begin{array}{c}B-103 \\
x\end{array}$ & $\begin{array}{c}B-104 \\
x\end{array}$ & $\begin{array}{c}B-105 \\
\times\end{array}$ & $\underset{x}{B-106}$ & $\begin{array}{c}\text { B-107 } \\
\times\end{array}$ \\
\hline & $x$ & $x$ & $\mathbf{x}$ & $x$ & $x$ & $x$ & $x$ & $\mathbf{x}$ & $x$ & $x$ & $x$ \\
\hline 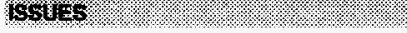 & $A X-101$ & AX-102 & AX-103 & AX-104 & B-101 & B-102 & B-103 & B-104 & B-105 & B-106 & B-107 \\
\hline Flammable Gas & o & 0 & 0 & 0 & o & 0 & o & $\mathbf{0}$ & 0 & o & 0 \\
\hline 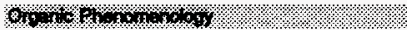 & 610. & $068 \%$ & 0. & 8 & (0. & 86 & 4 & 0 & 10 & 整 & \%: \\
\hline Safety Screening & 520 & 544 & 626 & 319 & 272 & 272 & 272 & 106 & 272 & 165 & 213 \\
\hline 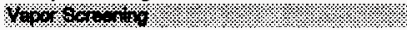 & to. 0 & 0. & 0 & 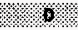 & \%. & 0 & 1801 & 0 & 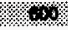 & o. & $\infty$ \\
\hline Vapor Spece Phenomenology & 0 & 0 & 0 & o & 0 & 0 & 350 & 0 & 0 & 0 & 0 \\
\hline H roornd & 6 & 0 & 0 & 68 & 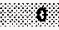 & 0.0 & 0. & 6 & 0 & \% & 0 \\
\hline Privatization & 0 & 0 & 0 & 0 & 0 & 0 & 0 & 0 & 0 & 0 & 0 \\
\hline 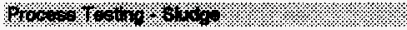 & 10 & 0 & 0 & 6 & 0 & 0 & 0.00 & 18 & 6 & 103 & $6:$ \\
\hline Process Testing - Supernatant & 0 & 0 & 0 & 0 & 0 & 0 & 0 & 0 & 0 & 0 & 0 \\
\hline Ronor & $1 \%$ & 0 & 10 & 160 & 0 & 0. & $\%$ & 3: & 6. & 0 & $=0 \%$ \\
\hline Historical Model Evaluation & 150 & 0 & 106 & 0 & 0 & 0 & 0 & 95 & 104 & 109 & 0 \\
\hline PRIORITIZATION - SOLID & $A X-101$ & AX-102 & $A X-103$ & AX-104 & B-101 & B-102 & B-103 & 8-104 & B-106 & B-106 & B-107 \\
\hline Total Score & 1480 & 994 & 773 & 419 & 272 & 902 & 822 & 354 & 376 & 374 & 213 \\
\hline Relattve Score \% (0 to 100) & 70 & 47 & 37 & 20 & 13 & 43 & 39 & 17 & 18 & 18 & 10 \\
\hline PRIORITIZATION - SUPERNATANT & $A X-101$ & $A X-102$ & AX-103 & $A X-104$ & B-101 & B-102 & B-103 & B-104 & B-105 & B-106 & B-107 \\
\hline Total Score & 0 & 0 & $\mathbf{0}$ & 0 & 0 & 0 & o & 0 & $\mathbf{0}$ & 0 & o \\
\hline Relattve Score \% (0 to 100) & 0 & 0 & 0 & 0 & 0 & 0 & 0 & 0 & 0 & 0 & o \\
\hline PRIORITIZATION - VAPOR & $A X-101$ & $A X-102$ & $A X-103$ & $a x-104$ & B-101 & B-102 & B-103 & B-104 & B-105 & B-106 & 8-107 \\
\hline Total Score & $\mathbf{0}$ & 0 & o & 0 & 0 & 0 & 950 & 0 & 600 & 0 & 600 \\
\hline Relattve Score $\%\left(\begin{array}{lll}0 & 00 & 100\end{array}\right)$ & $\mathbf{0}$ & 0 & $\mathbf{0}$ & o & 0 & 0 & 100 & 0 & 63 & 0 & 63 \\
\hline
\end{tabular}


WHC-SD-WM-TA-164 Rev 2

\section{ISSUE PRIORITIES AND WEIGHTS}

\begin{tabular}{|c|c|c|c|c|c|c|c|c|c|c|}
\hline Q-108 & B-109 & B-110 & B-111 & B-112 & B-201 & B-202 & B-203 & B-204 & BX-101 & $B X-102$ \\
\hline$x$ & $x$ & $x$ & $x$ & $x$ & $x$ & $x$ & $x$ & $x$ & $x$ & $x$ \\
\hline$x$ & $x$ & $x$ & $x$ & $x$ & $x$ & $x$ & $x$ & $x$ & $x$ & $x$ \\
\hline
\end{tabular}

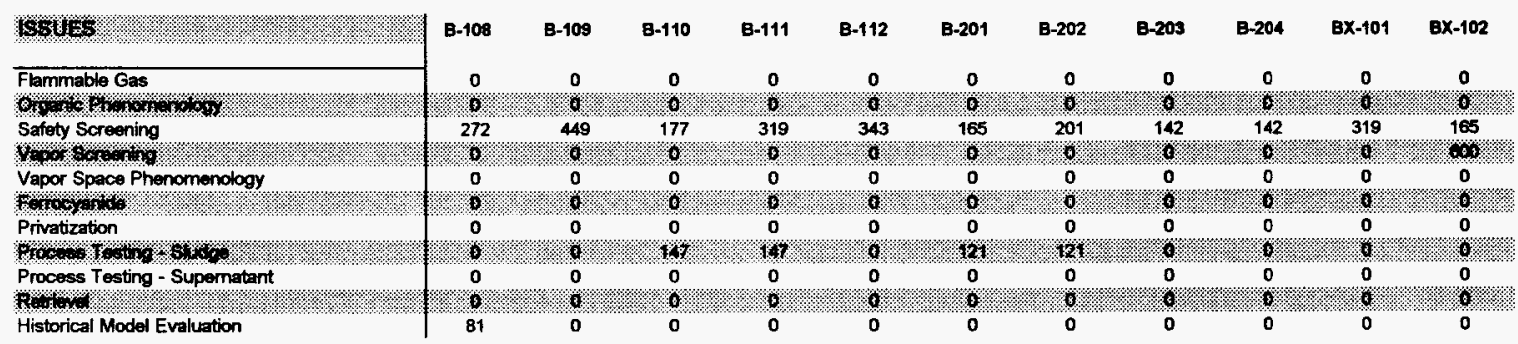

\begin{tabular}{|c|c|c|c|c|c|c|c|c|c|c|c|}
\hline $\begin{array}{l}\text { PRIORITIZATION - SOLID } \\
\text { Total Score }\end{array}$ & $\begin{array}{r}8-108 \\
353\end{array}$ & $\begin{array}{r}8-109 \\
449\end{array}$ & $\begin{array}{r}\text { B-110 } \\
324\end{array}$ & $\begin{array}{r}B-111 \\
466\end{array}$ & $\begin{array}{r}8-112 \\
343\end{array}$ & $\begin{array}{r}B-201 \\
286\end{array}$ & $\begin{array}{r}\text { B-202 } \\
322\end{array}$ & $\begin{array}{r}B-203 \\
142\end{array}$ & $\begin{array}{r}B-204 \\
142\end{array}$ & $\begin{array}{c}B \times-101 \\
319\end{array}$ & $\begin{array}{c}B x-102 \\
165\end{array}$ \\
\hline Relattve Score $\%(0$ to 100) & 17 & 21 & 15 & 22 & 16 & 14 & 15 & 7 & 7 & 15 & 8 \\
\hline PRIORITIZATION - SUPERNATANT & 8-108 & 8-109 & B-110 & B-111 & B-112 & B-201 & B-202 & B-203 & B-204 & $B x-101$ & BX-102 \\
\hline Total Score & 0 & 0 & 0 & 0 & 0 & 0 & 0 & o & o & 0 & 0 \\
\hline Relative Score $\%(0$ to 100) & 0 & 0 & 0 & 0 & 0 & 0 & 0 & o & $\mathbf{0}$ & 0 & 0 \\
\hline PRIORITIZATION - VAPOR & B-108 & B-109 & B-110 & B-111 & B-112 & B-201 & B-202 & B-203 & E-204 & Ex-101 & BX-102 \\
\hline Total Score & 0 & 0 & 0 & 0 & 0 & 0 & 0 & 0 & 0 & 0 & 600 \\
\hline Relattve score $\%(0$ to 100) & $\mathbf{0}$ & $\mathbf{0}$ & 0 & 0 & 0 & 0 & 0 & $\mathbf{0}$ & $\mathbf{0}$ & $\mathbf{0}$ & 63 \\
\hline
\end{tabular}


WHC-SD-WM-TA-164 Rev 2

ISSUE PRIORITIES AND WEIGHTS

\begin{tabular}{|c|c|c|c|c|c|c|c|c|c|c|c|}
\hline & $\begin{array}{c}8 x-103 \\
x\end{array}$ & $\begin{array}{c}\text { BX-104 } \\
x\end{array}$ & $\begin{array}{c}8 x-105 \\
x\end{array}$ & $\begin{array}{c}\text { BX-106 } \\
x\end{array}$ & $\begin{array}{c}\text { BX-107 } \\
x\end{array}$ & $\begin{array}{c}\text { BX-108 } \\
x\end{array}$ & $\begin{array}{c}B X-109 \\
x\end{array}$ & $\begin{array}{c}B X-110 \\
x\end{array}$ & $\begin{array}{c}\text { Ex-111 } \\
x\end{array}$ & $\begin{array}{c}\text { BX-112 } \\
x\end{array}$ & $\begin{array}{c}\text { BY-101 } \\
x\end{array}$ \\
\hline & $x$ & $x$ & $x$ & $\mathbf{x}$ & $x$ & $x$ & $x$ & $x$ & $x$ & $x$ & $x$ \\
\hline OS1SH. & BX-103 & BX-104 & BX-105 & BX-106 & $B \times-107$ & BX-108 & $B \times-109$ & $B X-110$ & Bx-111 & BX-112 & BY-101 \\
\hline Flammable Gas & o & 0 & o & 0 & 0 & $\mathbf{0}$ & $\mathbf{0}$ & 0 & 0 & $\mathbf{0}$ & 580 \\
\hline 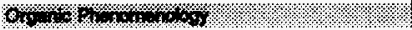 & o & 6 & 60 & 10\% & 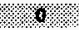 & 0 & 6 & 460 & 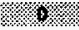 & 6 & $\%$ \\
\hline Safety Screening & 284 & 402 & 473 & 390 & 236 & 236 & 106 & 319 & 520 & 402 & 579 \\
\hline 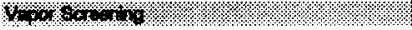 & bo & \% & 0 & 0 & 6 & 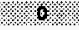 & 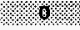 & \% & $6 \%$ & 60 & 604 \\
\hline Vapor Space Phenomenology & 0 & 350 & 0 & 0 & 0 & 0 & 0 & 0 & 0 & 0 & o \\
\hline 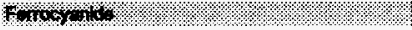 & 6 & 3. & 0 & $\%$ & \% & 8 & 8 & 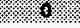 & 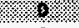 & 6 & 0 \\
\hline Privatization & 0 & 0 & 0 & 0 & 0 & 0 & $\mathbf{0}$ & 0 & 0 & $\mathbf{0}$ & $\mathbf{0}$ \\
\hline 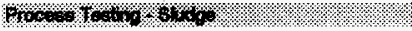 & 18 & 6 & 18 & 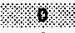 & 48 & 80 & 148 & q & 8 & 8 & 00 \\
\hline Process Testing - Supernatant & 0 & 0 & 0 & 0 & 0 & 0 & 0 & o & o & o & 0 \\
\hline nowoto $/ 2 \%$ & 80 & 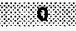 & 0 & 4 & 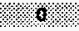 & o & o & 涯 & 86 & 83 & 80 \\
\hline Historical Model Evaluation & 0 & 0 & o & 0 & 0 & 0 & 81 & 102 & o & 102 & 0 \\
\hline PRIORITIZATION - SOLID & $B X-103$ & BX-104 & $8 \times-105$ & BX-106 & BX-107 & BX-108 & BX-109 & BX-110 & BX-111 & $B x-112$ & BY-101 \\
\hline Total Score & 420 & 402 & 1224 & 390 & 383 & 236 & 335 & 1378 & 520 & 504 & 1159 \\
\hline Relattve Score \% (0 to 100) & 20 & 19 & 58 & 18 & 18 & 11 & 16 & 65 & 25 & 24 & 55 \\
\hline PRIORITLATION - SUPERNATANT & ax-103 & BX-104 & $B \times-105$ & BX-106 & BX-107 & BX-108 & $8 x-109$ & EX-110 & BX-111 & ax-112 & BY-101 \\
\hline Total Score & 0 & 0 & 0 & 0 & 0 & 0 & 0 & $\mathbf{0}$ & 0 & 0 & 0 \\
\hline Relative Score \% (0 to 100) & 0 & 0 & $\mathbf{0}$ & 0 & $\mathbf{0}$ & 0 & 0 & $\mathbf{0}$ & $\mathbf{0}$ & 0 & $\mathbf{0}$ \\
\hline PRIORITIZATION - VAPOR & BX-103 & $B \times-104$ & $B \times-105$ & BX-106 & $B X-107$ & BX-108 & BX-109 & BX-110 & BX-111 & Ex-112 & EY-10t \\
\hline Total Score & 0 & 350 & 0 & o & 0 & 0 & 0 & 0 & 600 & 0 & 600 \\
\hline Relative Score \% (0 to 100) & 0 & 37 & 0 & 0 & 0 & 0 & 0 & 0 & 63 & 0 & 63 \\
\hline
\end{tabular}




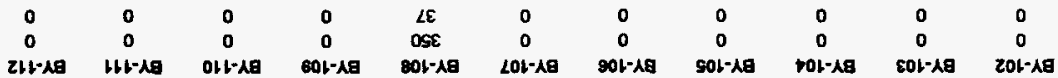

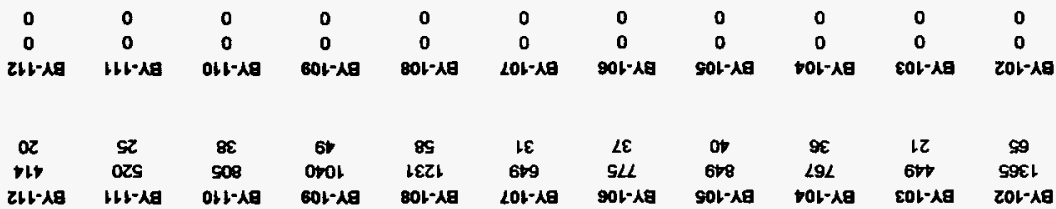

$(001$ 의 0$) \%$ acoss aspejay aroos 1701 YOd

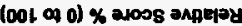
2.00510101

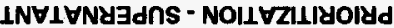

(001 09 o) \% anoos onp부요 a.00s 1401 al7Os - NOII ZILIYOIyd

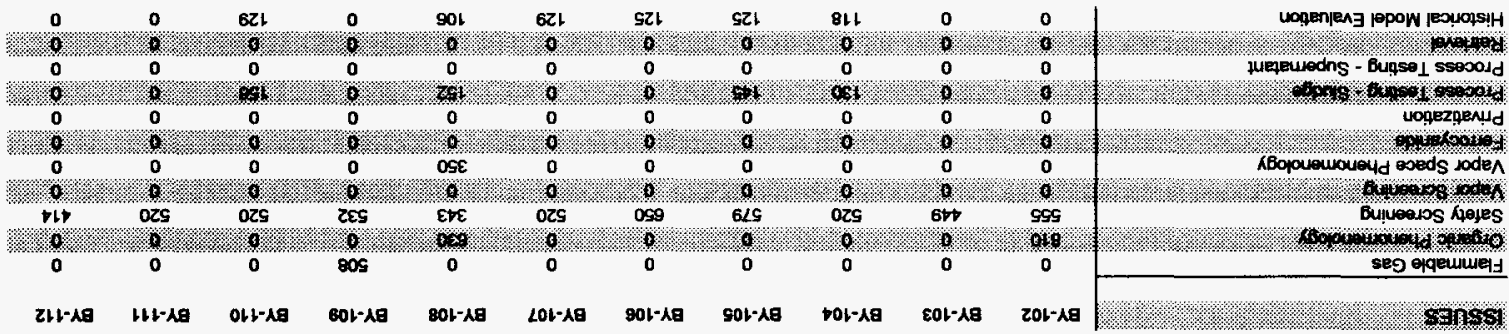

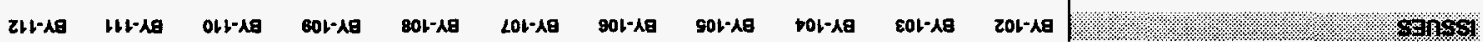

\begin{tabular}{|c|c|c|c|c|c|c|c|c|c|}
\hline$x$ & $x$ & $x$ & $x$ & $x$ & $x$ & $x$ & $x$ & $x$ & $x$ \\
\hline$x$ & $x$ & $x$ & $x$ & $x$ & $x$ & $x$ & $x$ & $x$ & $x$ \\
\hline
\end{tabular}

ZLL H HLV

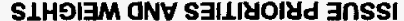

乙 ควด ค9I-YI-WM-वS-JHM 
WHC-SD-WM-TA-164 Rev 2

\section{ISSUE PRIORITIES AND WEIGHTS}

\begin{tabular}{|c|c|c|c|c|c|c|c|c|c|c|}
\hline C-101 & C-102 & C-103 & C-104 & C-105 & C-106 & C-107 & C-108 & C-109 & C-110 & c-111 \\
\hline$x$ & $x$ & $x$ & $x$ & $x$ & $\begin{array}{l}x \\
x\end{array}$ & $x$ & $x$ & $x$ & $x$ & $x$ \\
\hline$x$ & $x$ & $x$ & $x$ & $x$ & $x$ & $x$ & $x$ & $x$ & $x$ & $\mathbf{x}$ \\
\hline
\end{tabular}

\begin{tabular}{|c|c|c|c|c|c|c|c|c|c|c|c|}
\hline 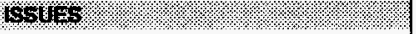 & C-101 & C-102 & C-103 & C-104 & C-105 & C-106 & C-107 & C-108 & C-109 & C-110 & C-111 \\
\hline Flammable Gas & 0 & 0 & o & 0 & 0 & 0 & 0 & 0 & 0 & 0 & 0 \\
\hline 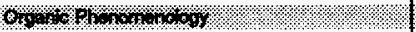 & ot & so & 106 & 8010 & 6 & 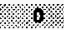 & $\%$ & 6 & o. & x & \%) \\
\hline Safety Screening & 165 & 213 & 402 & 567 & 106 & 355 & 225 & 165 & 142 & 177 & 165 \\
\hline $640 / 8<-14$ & 0 & 6 & 0 & 0 & 6 & 80 & 准o & 30 & 86 & 細 & 80 \\
\hline Vapor Space Phenomenology & 0 & 0 & 0 & 0 & 0 & 0 & 350 & 0 & 0 & 0 & 0 \\
\hline 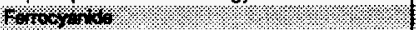 & 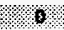 & \% & 6 & 8 & $\$$ & 6 & 0 & \% & 8 & (1) & 80 \\
\hline Privatzation & 0 & 0 & 0 & 0 & o & 270 & 0 & 0 & 0 & 0 & 0 \\
\hline 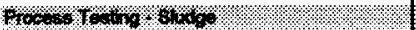 & 10 & 0 & $\%$ & 16 & 16 & 0 & 14 & 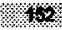 & xit & 急 & 10 \\
\hline Process Testing - Supernatant & 0 & 0 & 0 & 0 & D & o & 0 & 0 & 0 & 0 & 0 \\
\hline 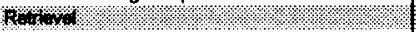 & 9. & 0 & 0 & 8 & 4 & XES & 80 & 3 & so & 6 & 0 \\
\hline Historical Model Evaluation & 0 & 115 & 0 & 95 & 0 & 102 & 0 & 0 & o & 0 & 0 \\
\hline
\end{tabular}

\begin{tabular}{|c|c|c|c|c|c|c|c|c|c|c|c|}
\hline PRIORITIZATION - SOLID & C-101 & c-102 & C-103 & C-104 & C-105 & C-106 & C-107 & C-108 & C-109 & C-110 & C.111 \\
\hline Total Score & 165 & 778 & 1004 & 1645 & 269 & 826 & 1182 & 318 & 278 & 177 & 165 \\
\hline Relattve Score $\%(0$ to 100$)$ & 8 & 37 & 48 & 78 & 13 & 39 & 56 & 15 & 13 & 8 & 8 \\
\hline PRIORITIZATION - SUPERNATANT & C-101 & C-102 & C-103 & C-104 & C-105 & C-106 & C-107 & C.108 & C-109 & C-110 & c.111 \\
\hline Total Score & 0 & $\mathbf{0}$ & 0 & $\mathbf{0}$ & $\mathbf{0}$ & 724 & $\mathbf{0}$ & 0 & 0 & o & 0 \\
\hline Relattve Score \% (0 to 100) & 0 & $\mathbf{0}$ & 0 & 0 & 0 & 62 & 0 & 0 & $\mathbf{0}$ & 0 & 0 \\
\hline PRIORITIZATION - VAPOR & C-101 & C-102 & C-103 & C-104 & C-405 & C-106 & C-107 & C-108 & C.109 & C-110 & C-111 \\
\hline Total Score & 0 & $\mathbf{0}$ & $\mathbf{0}$ & 0 & 0 & 0 & 350 & 0 & 0 & 0 & $\mathbf{0}$ \\
\hline Relattve score \% (0 to 100) & $\mathbf{0}$ & $\mathbf{0}$ & 0 & 0 & 0 & 0 & 37 & 0 & 0 & $\mathbf{0}$ & $\mathbf{0}$ \\
\hline
\end{tabular}


WHC-SD-WM-TA-164 Rev 2

ISSUE PRIORITIES AND WEIGHTS

\begin{tabular}{|c|c|c|c|c|c|c|c|c|c|c|c|}
\hline & $\begin{array}{c}\text { C-112 } \\
x\end{array}$ & $\begin{array}{c}\text { C-201 } \\
x\end{array}$ & $\begin{array}{c}\text { C-202 } \\
\times\end{array}$ & $\begin{array}{c}C-203 \\
x\end{array}$ & $\begin{array}{c}C-204 \\
x\end{array}$ & $\begin{array}{c}\text { S-101 } \\
\times\end{array}$ & $\begin{array}{c}S-102 \\
x\end{array}$ & $\begin{array}{c}\text { S-103 } \\
\times\end{array}$ & $\begin{array}{c}5-104 \\
\times\end{array}$ & $\begin{array}{c}\text { S-105 } \\
x\end{array}$ & $\begin{array}{c}S-106 \\
x\end{array}$ \\
\hline & $x$ & $x$ & $\mathbf{x}$ & $x$ & $x$ & $\mathbf{x}$ & $x$ & $x$ & $x$ & $x$ & $\mathbf{x}$ \\
\hline ESUES & C-112 & C-201 & C-202 & C-203 & C-204 & S-101 & s-102 & S-103 & S-104 & s-105 & S-106 \\
\hline Flammable Gas & o & o & 0 & o & 0 & 0 & 0 & o & 0 & 0 & 880 \\
\hline 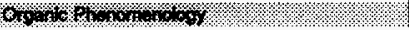 & 0 & 6 & $\Delta \%$ & 60 & 6i: & 6 & \%o. & $\%$ & 6. & o. & 6. \\
\hline Safety Screening & 106 & 165 & 165 & 236 & 142 & 449 & 402 & 343 & 343 & 225 & 272 \\
\hline 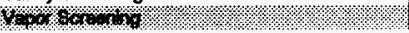 & 10. & 0 & 0 & 6. & 0 & 0 & $10:$ & 6. & 8. & 0 & 0.0. \\
\hline Vapor Space Phenomenology & 0 & o & 0 & 0 & 0 & 0 & 350 & o & o & 0 & o \\
\hline 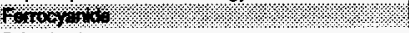 & 60 & a & $0 \%$ & 0. & o. & \% & 0. & 8... & 6. & 10 & 10.9 \\
\hline Privatization & 0 & 0 & 0 & 0 & 0 & 0 & 0 & o & a & 0 & o \\
\hline 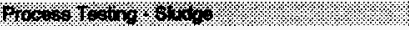 & $18 \%$ & 0 & 0 & 0. & o. & $18 \%$ & 0. & 8 & 24 & 60 & 0. \\
\hline Process Testing - Supernatant & 0 & 0 & 0 & 0 & 0 & 0 & 0 & $\circ$ & 0 & 0 & 0 \\
\hline Roun & 0 & 0 & $1: 0.0$ & (1) & ... 0. & 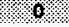 & 6. & 3 & 0. & 0. & 0. \\
\hline Historical Model Evaluation & 0 & o & 0 & 0 & 0 & 177 & 129 & 0 & o & 109 & 109 \\
\hline PRIORITLZATION - SOLID & C-112 & C-201 & C-202 & C-203 & C-204 & S-101 & S-102 & S-103 & S-104 & s-105 & S-108 \\
\hline Total Score & 243 & 165 & 975 & 236 & 142 & 813 & 981 & 343 & 584 & 333 & 1260 \\
\hline Relative Score $\%(0$ to 100$)$ & 12 & 8 & 46 & 11 & 7 & 39 & 47 & 16 & 28 & 16 & 60 \\
\hline PRIORITIZATION - SUPERNATANT & C-112 & C-201 & C-202 & C-203 & c-204 & S-101 & 5-102 & S-103 & S-104 & s-105 & S-106 \\
\hline Total Score & 0 & o & 0 & 0 & o & o & 0 & 0 & 0 & 0 & 0 \\
\hline Relattve Score \% (0 to 100) & 0 & o & o & 0 & $\mathbf{0}$ & D & o & 0 & 0 & 0 & 0 \\
\hline PRIORITIZATION - VAPOR & C-112 & C-201 & C-202 & C-203 & C-204 & S-101 & 5-102 & S-103 & S-104 & S-105 & S-106 \\
\hline Total Score & $\mathbf{0}$ & $\mathbf{0}$ & 0 & 0 & 0 & o & 350 & 0 & 0 & 0 & 0 \\
\hline Relattve Score \% ( $\left(\begin{array}{lll}0 & \text { to } & 100\end{array}\right)$ & o & 0 & 0 & 0 & 0 & 0 & 37 & 0 & 0 & 0 & 0 \\
\hline
\end{tabular}


WHC-SD-WM-TA-164 Rev 2

ISSUE PRIORITIES AND WEIGHTS

\begin{tabular}{|c|c|c|c|c|c|c|c|c|c|c|c|}
\hline & $\begin{array}{c}5.407 \\
x\end{array}$ & $\begin{array}{c}\text { S-108 } \\
x\end{array}$ & $\begin{array}{c}5-109 \\
x\end{array}$ & $\begin{array}{c}5-110 \\
x\end{array}$ & $\begin{array}{c}s-111 \\
x\end{array}$ & $\begin{array}{c}s-112 \\
x\end{array}$ & $\begin{array}{c}5 x-101 \\
x\end{array}$ & $\begin{array}{c}\text { 5x-102 } \\
x\end{array}$ & $\begin{array}{c}\text { sx-103 } \\
x\end{array}$ & $\begin{array}{c}5 x-104 \\
x\end{array}$ & $\begin{array}{c}5 x-105 \\
x\end{array}$ \\
\hline & $x$ & $\mathbf{x}$ & $\mathbf{x}$ & $\mathbf{x}$ & $x$ & $x$ & $\mathbf{x}$ & $x$ & $x$ & $\mathbf{x}$ & $\mathbf{x}$ \\
\hline 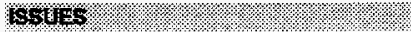 & S-107 & S-108 & S-109 & S-110 & S.111 & S-112 & $5 x-101$ & $\mathbf{5 x - 1 0 2}$ & $5 x-103$ & sx-104 & $5 x-105$ \\
\hline Flammabla Gas & 0 & 0 & $\mathbf{0}$ & o & 0 & 508 & 0 & 0 & 0 & 0 & 0 \\
\hline 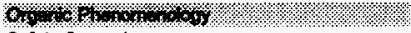 & $\%$ & 6 & 0 & 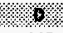 & 40 & 6 & 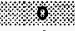 & 娄 & $\operatorname{seg}$ & 器1 & 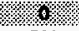 \\
\hline Safety Screening & 449 & 165 & 201 & 449 & 449 & 201 & 579 & 626 & 626 & $\mathbf{5 0 8}$ & 508 \\
\hline W $40 \times 4 \times$ & 样 & 0 & 10 & 60 & 6 & 6 & Q⿻ & 祭 & $\%$ & 40 & 范 \\
\hline Vapor Space Phenomenology & 0 & 0 & 0 & 0 & 0 & 0 & o & 0 & 0 & 0 & 0 \\
\hline $1010001 \%$ & 8 & 6 & 8 & o & 8 & 0 & 0 & \% & 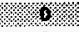 & \% & 0 \\
\hline Privatization & 0 & 0 & 0 & 0 & a & 0 & 0 & 0 & 0 & 0 & 0 \\
\hline 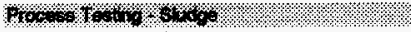 & 48 & 6 & 60 & 46 & 6 & $\%$ & 84 & 荧 & \% & 14\% & 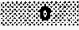 \\
\hline Process Testing - Supernatant & 0 & 0 & 0 & 0 & o & 0 & 0 & 0 & 0 & 0 & 0 \\
\hline Horofll & 8 & ol & 10\% & $\ddot{6}$ & $\%$ & 0 & 4 & 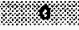 & s. & \% & 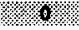 \\
\hline Historical Model Evaluation & 163 & 109 & 109 & 159 & 163 & 0 & 200 & 163 & 129 & 163 & 143 \\
\hline PRIORITIZATION - SOLID & S-107 & S-108 & S-109 & S-110 & S-114 & $5-1+2$ & $5 x-101$ & $5 x-102$ & $5 x-103$ & $5 x-104$ & $5 x-105$ \\
\hline Total Score & 817 & 274 & 309 & 769 & 1053 & 709 & 1020 & 790 & 1656 & 859 & 651 \\
\hline Relattve Score \% $(0$ to 100$)$ & 39 & 13 & 15 & 36 & 50 & 34 & 48 & 37 & 78 & 41 & 31 \\
\hline PRIORITIZATION - SUPERNATANT & S-107 & S-108 & S-109 & s-110 & S-111 & S-112 & sx-101 & $5 x-102$ & $5 x-103$ & $5 x-104$ & $5 \times-105$ \\
\hline Total score & $\mathbf{0}$ & 0 & 0 & 0 & 0 & 0 & 0 & 0 & $\mathbf{0}$ & 0 & $\mathbf{0}$ \\
\hline Relattve score \% (0 to 100) & 0 & 0 & 0 & 0 & 0 & 0 & 0 & 0 & o & $\mathbf{0}$ & 0 \\
\hline PRIORITIZATION - VAPOR & s-107 & S-108 & $s-109$ & $s-110$ & S-111 & S-112 & $5 x-101$ & $5 x-102$ & sx-103 & $5 x-104$ & $5 x-105$ \\
\hline Total Score & 0 & 0 & 0 & 600 & 0 & 0 & $\mathbf{0}$ & $\mathbf{0}$ & o & 0 & 0 \\
\hline Relattve Score \% (0 to 100) & 0 & 0 & 0 & 63 & o & o & $\mathbf{0}$ & 0 & $\mathbf{0}$ & 0 & 0 \\
\hline
\end{tabular}


WHC-SD-WM-TA-164 Rev 2

\section{ISSUE PRIORITIES AND WEIGHTS}

\begin{tabular}{|c|c|c|c|c|c|c|c|c|c|c|}
\hline $5 X-106$ & $5 x-107$ & sX-108 & sX-109 & $5 x-110$ & $s x-111$ & sx-112 & $5 x-113$ & $5 x-114$ & sX-115 & $T-101$ \\
\hline$x$ & $x$ & $x$ & $x$ & $x$ & $x$ & $x$ & $x$ & $x$ & $x$ & $x$ \\
\hline$x$ & $x$ & $x$ & $x$ & $x$ & $x$ & $x$ & $x$ & $x$ & $x$ & $x$ \\
\hline
\end{tabular}

\begin{tabular}{|c|c|c|c|c|c|c|c|c|c|c|c|}
\hline 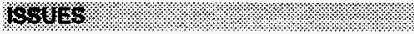 & $5 x-106$ & sX-107 & sx-108 & $5 x-109$ & $5 x-110$ & $s x-111$ & sX-112 & $5 x-113$ & $5 x-114$ & $5 x-115$ & T-101 \\
\hline Flammable Gas & 508 & 0 & o & o & 0 & 0 & 0 & 0 & 0 & o & 0 \\
\hline 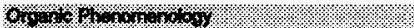 & $\%$ & $\alpha$ & 80 & os: & 0 & 6 & 8 & 0 & 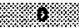 & 袨 & $0 \%$ \\
\hline Safety Screening & 343 & 343 & 414 & 402 & 343 & 343 & 343 & 165 & 343 & 343 & 319 \\
\hline 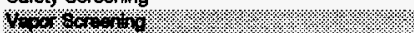 & $\%$ & 60 & 609 & 0. & $6 \%$ & $\%$ & 60 & Wh & -8 & 6 & 0,5 \\
\hline Vapor Space Phenomenology & 0 & 0 & 0 & 0 & 0 & 0 & 0 & 0 & 0 & 0 & 0 \\
\hline 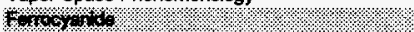 & 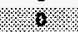 & 0. & 8 & 0 & 3 & 6 & 6 & 6 & 0 & o & 80 \\
\hline Privatization & 0 & 0 & o & 0 & 0 & 0 & 0 & 0 & 0 & 0 & 0 \\
\hline 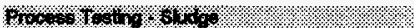 & 0 & 26 & 200 & $2 \times 1$ & 189 & 6 & 6 & $1 \mathrm{x}$ & 8 & 10 & 8 \\
\hline Process Testing - Supermatant & 0 & 0 & 0 & 0 & 0 & 0 & 0 & 0 & 0 & 0 & 0 \\
\hline Rownow & 稵 & 0 & 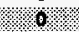 & 19. & a. & 6 & 0 & si & 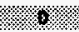 & 8 & 6 \\
\hline Historical Model Evaluation & 0 & 0 & 129 & 0 & 0 & 0 & 0 & 0 & 0 & 0 & 0 \\
\hline PRIORITIZATION - SOLID & $5 x-106$ & sx-107 & $s x-108$ & $5 x-109$ & $5 \times-410$ & $s x-119$ & $5 x-112$ & $5 x-113$ & sx-114 & sx-116 & $T-101$ \\
\hline Total score & 1301 & 575 & 793 & 633 & 540 & 343 & 343 & 339 & 343 & 343 & 319 \\
\hline Relattve Score \% (0 to 160) & 62 & 27 & 38 & 30 & 26 & 16 & 16 & 16 & 16 & 16 & 15 \\
\hline PRIORITIZATION - SUPERNATANT & $5 x-106$ & $5 x-107$ & $5 x-108$ & $5 \times-109$ & $s x-110$ & $5 x-111$ & $5 x-112$ & $5 x-113$ & $5 x-114$ & $5 x-115$ & $T-101$ \\
\hline Total score & 0 & 0 & o & 0 & 0 & 0 & 0 & 0 & 0 & 0 & 0 \\
\hline Relattve Scone $\%(0$ to 100) & 0 & 0 & 0 & 0 & 0 & 0 & 0 & 0 & 0 & 0 & 0 \\
\hline PRIORITIZATION - VAPOR & sX-106 & $5 x-107$ & $5 x-108$ & $5 X-109$ & $5 x-110$ & $5 x-111$ & $5 x-112$ & sx-113 & $5 x-114$ & $5 x-115$ & $T-101$ \\
\hline Total Score & 0 & 600 & 600 & 0 & 0 & 600 & 600 & 0 & 600 & 0 & 600 \\
\hline Relattve Score $\%$ (0 to 100) & 0 & 63 & 63 & 0 & 0 & 63 & 63 & 0 & 63 & 0 & 63 \\
\hline
\end{tabular}


WHC-SD-WM-TA-164 Rev 2

\section{ISSUE PRIORITIES AND WEIGHTS}

\begin{tabular}{|c|c|c|c|c|c|c|c|c|c|c|c|}
\hline & $\underset{x}{T-102}$ & $\underset{x}{T-103}$ & $\begin{array}{c}T-104 \\
x\end{array}$ & $\underset{x}{T-105}$ & $\begin{array}{c}T-106 \\
x\end{array}$ & $\begin{array}{c}T-107 \\
x\end{array}$ & $\begin{array}{c}T-108 \\
x\end{array}$ & $\begin{array}{c}T-109 \\
\times\end{array}$ & $\begin{array}{c}T-110 \\
x\end{array}$ & $\begin{array}{c}T-111 \\
x\end{array}$ & $\underset{x}{T-112}$ \\
\hline & $x$ & $\mathbf{x}$ & $x$ & $x$ & $x$ & $x$ & $x$ & $x$ & $x$ & $x$ & $x$ \\
\hline 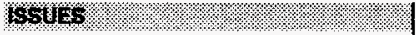 & T-102 & T-103 & $T-104$ & T-105 & $T-106$ & T-107 & $T-408$ & T.109 & T.110 & T-111 & T-112 \\
\hline Flammable Gas & o & o & 0 & 0 & 0 & 0 & 0 & 0 & 0 & $\mathbf{0}$ & $\mathbf{0}$ \\
\hline 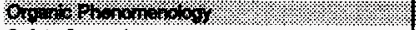 & 6 & 0 & 0 & 6) & 0 & 0 & \%. & 6 & 6 & 45 & \%. \\
\hline Safety Sereening & 106 & 142 & 355 & 213 & 106 & 177 & 142 & 165 & 236 & 177 & 177 \\
\hline 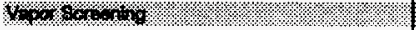 & 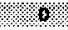 & 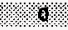 & 6 & $6:$ & $=0$ & 10.0 & 0 & 2. & 60 & a & $0 \%$ \\
\hline Vapor Space Phenomenology & o & 0 & 0 & 0 & 0 & 0 & 0 & 0 & 0 & 0 & 0 \\
\hline 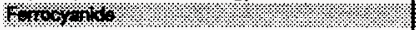 & 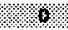 & 0 & 0 . & 10 & $\%$ & 6 & $\theta$ & 6 & \% & 0 & 0.1 \\
\hline Privatization & 0 & 0 & 0 & 0 & o & 0 & 0 & 0 & 0 & o & 0 \\
\hline 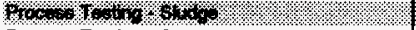 & 0 & 14 & 40 & 0 & 6. & $17 \%$ & $\%$ & 160 & 1) & $\pi /$ & \%: \\
\hline Process Testing - Supernatant & 0 & 0 & 0 & 0 & 0 & 0 & 0 & 0 & 0 & o & 0 \\
\hline Mons. & 0 & 1.0 & $0:$ & 0 & 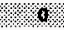 & 6. & 0. & 6 & o. & 10 & 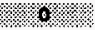 \\
\hline Historical Model Evaluation & 0 & 0 & o & 0 & 0 & 0 & 81 & 81 & o & 0 & 0 \\
\hline PRIORITIZATION - SOLID & T-102 & $T-103$ & $T-104$ & $T-105$ & $T-106$ & $T-107$ & $T-108$ & T-109 & T-110 & T-111 & T-112 \\
\hline Total Score & 106 & 289 & 502 & 213 & 106 & 324 & 223 & 347 & 236 & 774 & 177 \\
\hline Relattve Score \% (0 to 100) & 5 & 14 & 24 & 10 & 5 & 15 & 11 & 16 & 11 & 37 & 8 \\
\hline PRIORITIZATION - SUPERNATANT & r-102 & T-103 & T-104 & $T-105$ & $T-108$ & T-107 & $T-108$ & $T-109$ & $T-410$ & T-111 & T.112 \\
\hline Total Score & o & o & o & 0 & 0 & 0 & 0 & 0 & o & 0 & 0 \\
\hline Relattve score \% (0 to 100) & 0 & 0 & o & 0 & 0 & 0 & 0 & 0 & o & 0 & 0 \\
\hline PRIORITIZATION - VAPOR & T-102 & $T-103$ & $T-104$ & $T-105$ & $T-106$ & $T-107$ & $T-108$ & $T-109$ & $T-110$ & $T-111$ & $T-112$ \\
\hline Total score & 0 & D & 0 & 0 & 0 & 0 & 0 & 0 & 0 & o & 0 \\
\hline Relative Score $\%(0$ to 100$)$ & 0 & 0 & 0 & 0 & 0 & 0 & 0 & 0 & 0 & 0 & $\mathbf{0}$ \\
\hline
\end{tabular}


WHC-SD-WM-TA-164 Rev 2

\section{ISSUE PRIORITIES AND WEIGHTS}

$\begin{array}{ccccccccccc}T-201 & T-202 & T-203 & T-204 & T X-101 & T X-102 & T X-103 & T X-104 & T X-105 & T X-106 & T X-107 \\ \times & x & x & x & x & x & x & x & x & x & x \\ x & x & x & x & x & x & x & x & x & x & x\end{array}$

\begin{tabular}{|c|c|c|c|c|c|c|c|c|c|c|c|}
\hline Mollos & $T-201$ & $T-202$ & $T-203$ & T-204 & TX-101 & TX-102 & TX-103 & $T X-104$ & TX-10s & $T X-106$ & $T X-107$ \\
\hline Flammable Gas & 0 & 0 & 0 & 0 & 0 & $\mathbf{0}$ & 0 & 0 & 0 & 0 & 0 \\
\hline 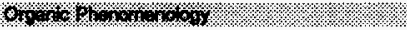 & g & बै & 6 & m & o & 8 & 8 & $\%$ & 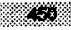 & 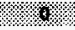 & (⿻) \\
\hline Safety Screening & 165 & 165 & 106 & 201 & 461 & 473 & 213 & 496 & 236 & 390 & 319 \\
\hline 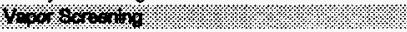 & $8 \mathrm{BH}$ & 100 & 60 & osa & 630 & 80 & $\%$ & 6so & ssto & (ess & $\%$ \\
\hline Vapor Space Phenomenology & 0 & 0 & 0 & 0 & 0 & 0 & 0 & 0 & 0 & 0 & 0 \\
\hline Wob $140 \%$ & \% & 8 & 0 & 楸 & \% & o. & $\%$ & \% & 8s & \% & $\%$ \\
\hline Privatization & 0 & 0 & 0 & 0 & 0 & 0 & 0 & $\mathbf{0}$ & o & 0 & o \\
\hline $100 \%$ oss & o & 6 & 10 & \% & 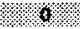 & 0 & $\%$ & \% & Q6. & as & 6 \\
\hline Process Testing - Superratant & 0 & 0 & o & 0 & 0 & 0 & 0 & o & 0 & 0 & 0 \\
\hline now w 1 l. & o & 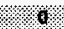 & 0 & 6 & \% & 0 & 8 & 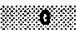 & 次 & +2 & 8 \\
\hline Historical Model Evaluation & 0 & 0 & o & 0 & 0 & 0 & 0 & 0 & 104 & 109 & 0 \\
\hline
\end{tabular}

\begin{tabular}{|c|c|c|c|c|c|c|c|c|c|c|c|}
\hline PRIORITIZATION - SOLID & T-201 & $T-202$ & $T-203$ & $T-204$ & $T X-101$ & TX-102 & $T X-103$ & $T X-104$ & $T X-105$ & $T X-106$ & TX-107 \\
\hline Total Score & 165 & 165 & 106 & 201 & 461 & 473 & 213 & 496 & 790 & 499 & 319 \\
\hline Relattve Score \% (0 to 100) & 8 & 8 & 5 & 10 & 22 & 22 & 10 & 24 & 37 & 24 & 15 \\
\hline PRIORITIZATION - SUPERNATANT & T-201 & $T-202$ & $T-203$ & $T-204$ & $T X-101$ & $T X-102$ & TX-103 & TX-104 & $T X-108$ & $T X-108$ & TX-107 \\
\hline Total Seore & 0 & 0 & 0 & o & 0 & 0 & o & 0 & 0 & 0 & 0 \\
\hline Relattve score $\%(0$ to 100$)$ & 0 & 0 & 0 & 0 & 0 & 0 & 0 & 0 & 0 & o & 0 \\
\hline PRIORITIZATION - VAPOR & $T-201$ & $T-202$ & $T-203$ & $T-204$ & TX-101 & $T X-102$ & TX-103 & $T X-104$ & $T X-105$ & $T X-106$ & $T X-107$ \\
\hline Total Score & 600 & 600 & 600 & 600 & 600 & 600 & 600 & 600 & 0 & 600 & 0 \\
\hline Relattve Score $\%(0$ to 100$)$ & 63 & 63 & 63 & 63 & 63 & 63 & 63 & 63 & 0 & 63 & 0 \\
\hline
\end{tabular}


WHC-SD-WM-TA-164 Rev 2

\section{ISSUE PRIORITIES AND WEIGHTS}

$\begin{array}{ccccccccccc}T X-108 & T X-109 & T X-110 & T X-111 & T X-112 & T X-113 & T X-114 & T X-115 & T X-116 & T X-117 & T X-118 \\ x & x & x & x & x & x & x & x & x & x & x \\ x & x & x & x & x & x & x & x & x & x & x\end{array}$

\begin{tabular}{|c|c|c|c|c|c|c|c|c|c|c|c|}
\hline 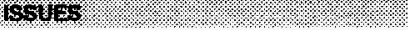 & $T X-108$ & $T X-109$ & TX-110 & $T X-111$ & $T X-112$ & $T X-113$ & $T X-114$ & TX-115 & $T X-116$ & $T X-117$ & $T X-118$ \\
\hline Flammabla Ges & o & $\mathbf{0}$ & 0 & 0 & 0 & o & 0 & 0 & o & 0 & 0 \\
\hline os & 89 & 0 & 80 & \% & 8 & 0 & \% & 80 & so & 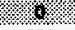 & \%o \\
\hline Safety Screening & 236 & 213 & 520 & 579 & 295 & 402 & 236 & 295 & 343 & 236 & 591 \\
\hline 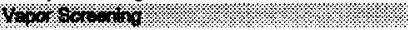 & 800 & 800 & $00 \%$ & o & 800 & 60 & \% & 260 & 6 & 8 & 0 \\
\hline Vapor Space Phenomenology & 0 & 0 & 0 & 0 & 0 & o & $\mathbf{0}$ & 0 & o & 0 & 0 \\
\hline 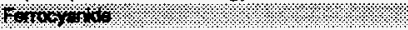 & 0 & 6 & 0. & 10. & 类 & 8 & 0 & 6. & 40 & 10 & 0. \\
\hline Privatization & 0 & 0 & 0 & 0 & 0 & o & 0 & 0 & 0 & 0 & 0 \\
\hline 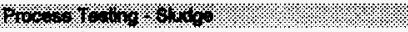 & 0 & 4 & 0 & 106 & 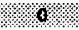 & 8 & 8 & se & Tos & 吆 & 14: \\
\hline Process Testing - Supernatant & 0 & 0 & 0 & 0 & 0 & 0 & 0 & 0 & 0 & 0 & 0 \\
\hline 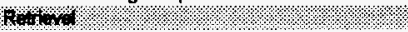 & 8 & 4 & (1) & \% 0 & 8 & 0 & \% & o & so & 40 & 0 \\
\hline Historical Model Evaluation & 0 & 51 & 109 & 109 & 109 & 129 & 129 & 109 & 129 & 129 & 150 \\
\hline PRIORITIZATION - SOLID & $T X-108$ & $T X-109$ & $T X-110$ & $T X-111$ & $T X-112$ & $T X-113$ & TX-114 & TX-115 & $T X-116$ & $T X-117$ & TX-118 \\
\hline Total Score & 236 & 264 & 629 & 791 & 404 & 531 & 366 & 404 & 575 & 366 & 1310 \\
\hline Relattve Score \% (0 to 100) & 11 & 13 & 30 & 38 & 19 & 25 & 17 & 19 & 27 & 17 & 62 \\
\hline PRIORITIZATION - SUPERNATANT & TX-108 & TX-109 & $T X-110$ & $T X-111$ & TX-112 & TX-113 & TX-114 & TX-115 & TX-116 & $T X-117$ & $T X-118$ \\
\hline Total score & 0 & o & $\mathbf{0}$ & 0 & 0 & 0 & 0 & 0 & 0 & 0 & 0 \\
\hline Relattve score \% (0 to 100) & 0 & 0 & $\mathbf{0}$ & 0 & 0 & 0 & $\mathbf{0}$ & 0 & $\mathbf{0}$ & 0 & 0 \\
\hline PRIORITIZATION - VAPOR & $T X-108$ & TX-109 & $T X-110$ & $T X-111$ & $T X-112$ & TX-113 & $T X-114$ & $T X-115$ & $T X-116$ & $T X-117$ & $T X \cdot 118$ \\
\hline Total score & 600 & 600 & 600 & D & 600 & 600 & 600 & 600 & 600 & 600 & 0 \\
\hline Relattve Score $\%$ (0 to 100) & 63 & 63 & 63 & 0 & 63 & 63 & 63 & 63 & 63 & 63 & 0 \\
\hline
\end{tabular}


WHC-SD-WM-TA-164 Rev 2

\section{ISSUE PRIORITIES AND WEIGHTS}

\begin{tabular}{|c|c|c|c|c|c|c|c|c|c|c|c|}
\hline Hos 5 S & TY-101 & $T \gamma-102$ & Tr-103 & $T r-104$ & TY-105 & $\mathbf{T} \gamma-106$ & U-101 & U-102 & U-103 & U-104 & $U-105$ \\
\hline Flammable Gas & 0 & 0 & 0 & 0 & 0 & 0 & 0 & 0 & 760 & $\mathbf{0}$ & 0 \\
\hline 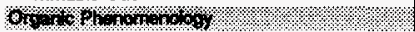 & 0 & oro & 6. & 40 & 0 & 0 & 8 & \%o & 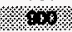 & \% & 000 \\
\hline Safety Screening & 165 & 213 & 106 & 177 & 142 & 165 & 213 & 520 & 449 & 165 & 461 \\
\hline 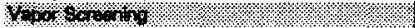 & 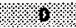 & 6 & \% & 80 & 630 & 0 & $\%$ & so & s & a & 0 \\
\hline Vapor Spece Phenomenology & 0 & 0 & 350 & 0 & 0 & 0 & 0 & 0 & 0 & 0 & 0 \\
\hline 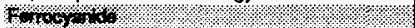 & 6 & 6 & 6 & 0 & 0 & 6 & 6 & 8 & \% & (a. & 60 \\
\hline Privatization & 0 & 0 & 0 & 0 & 0 & 0 & 0 & 0 & 0 & 0 & 0 \\
\hline 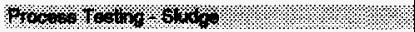 & 0 & 6 & 0 & $11 \%$ & 14 & 0 & 0 & xo & 哜 & $\%$ & 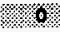 \\
\hline Process Testing - Supernatant & 0 & 0 & 0 & 0 & 0 & 0 & 0 & o & 0 & o & 0 \\
\hline nork & $\%$ & 6 & 0 & \% & a. & 0. & 0 & 然 & sis & a & so \\
\hline Historical Model Evaluation & 0 & 0 & 0 & 0 & 88 & 0 & 0 & 125 & 0 & 0 & 125 \\
\hline PRIORITIZATION - SOLID & Tr-101 & $\pi Y-102$ & $T r-103$ & $\pi-104$ & TY-105 & $\pi \gamma-106$ & U-401 & $U-102$ & U-103 & U-104 & U-105 \\
\hline Total Score & 165 & 1023 & 106 & 748 & 375 & 165 & 213 & 1455 & 2100 & 165 & 1485 \\
\hline Relative Score \% (0 to 100) & 8 & 48 & 5 & 35 & 18 & 8 & 10 & 69 & 100 & 8 & 70 \\
\hline PRIORITIZATION - SUPERNATANT & $T Y-101$ & $T r-102$ & TY.103 & $\pi-104$ & Tr-105 & TY-106 & U-101 & U-102 & U-103 & U-104 & $U-405$ \\
\hline Total Score & 0 & 0 & 0 & 0 & 0 & 0 & 0 & 0 & D & 0 & 0 \\
\hline Relative score $\%(0$ to 100$)$ & 0 & 0 & 0 & o & 0 & 0 & 0 & 0 & $\mathbf{0}$ & o & 0 \\
\hline PRIORITIZATION - VAPOR & TY-101 & $\pi-102$ & Tr-103 & TY-104 & TY-105 & $T Y-106$ & U-101 & U-102 & U-103 & U-104 & U-108 \\
\hline Total score & 0 & 0 & 350 & 0 & 600 & 0 & 0 & 0 & 0 & 0 & 0 \\
\hline Retattve Score \% (0 to 100) & 0 & 0 & 37 & $\mathbf{0}$ & 63 & 0 & 0 & 0 & 0 & 0 & 0 \\
\hline
\end{tabular}


WHC-SD-WM-TA-164 Rev 2

\section{ISSUE PRIORITIES AND WEIGHTS}

$\begin{array}{crrrrrrrrrr}U-106 & U-107 & U-108 & U-109 & U-110 & U-111 & U-112 & U-201 & U-202 & U-203 & U-204 \\ \times & x & x & x & x & x & x & x & x & \times & \times \\ x & x & x & x & x & x & x & x & x & \times & \times\end{array}$

\begin{tabular}{|c|c|c|c|c|c|c|c|c|c|c|c|}
\hline$\Delta \Delta u=6$ & U-106 & U-107 & U-108 & U-109 & $U-110$ & $U-111$ & U-112 & U-201 & U-202 & U-203 & U-204 \\
\hline Flammable Gas & 0 & 0 & 0 & 0 & 0 & 0 & 0 & 0 & 0 & 0 & $\mathbf{0}$ \\
\hline 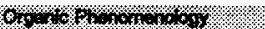 & $\%$ & 80 & 8010 & 86 & * & \% & \% & $\%$ & o. & $\$ 4$ & $\%$ \\
\hline Safety Screening & 567 & 449 & 449 & 567 & 142 & 485 & 142 & 106 & 106 & 106 & 106 \\
\hline $46,1 \% \alpha-10 \%$ & 8 & 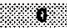 & 0 & 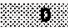 & 6 & \% & 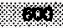 & 6 & 6 & 36 & 6 \\
\hline Vapor Space Phenomenology & 0 & 0 & 0 & o & o & 0 & 350 & 0 & 0 & 0 & 0 \\
\hline 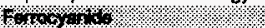 & 3 & 8 & 0 & 0. & 68 & 6 & o & 40 & 0 & ot & 唡 \\
\hline Privatization & 0 & 0 & 0 & 0 & o & 0 & 0 & 0 & 0 & 0 & 0 \\
\hline 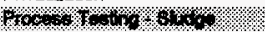 & 0 & o & 0 & 119 & $1 / 7$ & 6 & $\theta$ & \% & 6 & 4 & \% \\
\hline Process Testing - Supernatant & 0 & 0 & 0 & 0 & 0 & 0 & 0 & 0 & 0 & 0 & 0 \\
\hline 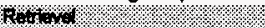 & 8 & 8 & 6 & o. & 莎 & 0 & s. & 8 & 6 & 4 & $\%$ \\
\hline Historical Model Evaluation & 104 & 125 & 125 & 125 & 0 & 106 & 0 & 0 & 0 & 0 & 0 \\
\hline
\end{tabular}

PRIORITIZATION - SOLID Total Score

Relattve score \% (0 to 100)

PRIORITIZATION - SUPERNATANT Total Score

Relative Score $\%(0$ to 100)

PRIORITIZATION - VAPOR

Total Score

Relattive score \% (0 to 100)

$\begin{array}{cccccccccrr}U-106 & U-107 & U-108 & U-109 & U-110 & U-111 & U-112 & U-201 & U-202 & U-203 & U-204 \\ 1121 & 1474 & 1384 & 1621 & 289 & 1041 & 142 & 106 & 106 & 556 & 556 \\ 53 & 70 & 66 & 77 & 14 & 49 & 7 & 5 & 5 & 26 & 26\end{array}$

\begin{tabular}{|c|c|c|c|c|c|c|c|c|c|c|}
\hline U-108 & U-107 & U-108 & U-109 & 0.110 & U-111 & U-112 & U-201 & U-202 & U-203 & $U-204$ \\
\hline 0 & 0 & 0 & 0 & 0 & 0 & 0 & 0 & 0 & 0 & 0 \\
\hline 0 & 0 & 0 & 0 & 0 & 0 & 0 & 0 & 0 & 0 & 0 \\
\hline
\end{tabular}

$\begin{array}{ccccccccccc}U-106 & U-107 & U-108 & U-109 & U-110 & U-111 & U-112 & U-201 & U-202 & U-203 & U-204 \\ 0 & 0 & 0 & 0 & 0 & 0 & 950 & 0 & 0 & 0 & 0 \\ 0 & 0 & 0 & 0 & 0 & 0 & 100 & 0 & 0 & 0 & 0\end{array}$


WHC-SD-WM-TA-164 Rev 2

\section{ISSUE PRIORITIES AND WEIGHTS}

\begin{tabular}{|c|c|c|c|c|c|c|c|c|c|c|}
\hline AN-101 & $\begin{array}{c}\text { AN-102 } \\
x\end{array}$ & $\begin{array}{c}\text { AN- } 103 \\
x\end{array}$ & $\begin{array}{c}\text { AN-104 } \\
x\end{array}$ & $\begin{array}{c}\text { AN-105 } \\
\times\end{array}$ & $\begin{array}{c}\text { AN-106 } \\
x\end{array}$ & $\begin{array}{c}\text { AN-107 } \\
x\end{array}$ & AP-101 & AP-102 & AP-103 & AP-104 \\
\hline $\mathbf{x}$ & $x$ & $x$ & $x$ & $x$ & $x$ & $x$ & $\mathbf{x}$ & $x$ & $x$ & $\mathbf{x}$ \\
\hline $\mathbf{x}$ & $x$ & $\mathbf{x}$ & $x$ & $x$ & $\mathbf{x}$ & $x$ & $x$ & $x$ & $x$ & $\mathbf{x}$ \\
\hline
\end{tabular}

\begin{tabular}{|c|c|c|c|c|c|c|c|c|c|c|c|}
\hline SSOBLS & AN-101 & AN-102 & AN-103 & AN-104 & AN-105 & AN-106 & AN-107 & AP-101 & AP-102 & AP-103 & AP.104 \\
\hline Flammable Gas & o & 0 & 1000 & 1000 & 1000 & 0 & 580 & o & o & $\mathbf{0}$ & o \\
\hline 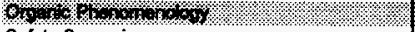 & s. & 8 & 80 & 86 & a & to & 6 & 6. & 3. & a & 80. \\
\hline Safety Screening & 106 & 402 & 532 & 532 & 355 & 284 & 461 & 0 & 177 & 0 & 0 \\
\hline 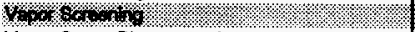 & so & 0 & o. & \% & o. & 10 & 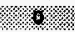 & 然 & 6 & ax & 0 \\
\hline Vapor Space Phenomenology & 0 & 0 & 0 & 0 & 0 & 0 & 0 & 0 & 0 & 0 & 0 \\
\hline 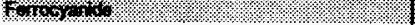 & $5 \%$ & 30 & 0 & 6 & 60 & 10 & 6 & 6 & 80 & $\$ 2$ & 60 \\
\hline Privatization & 255 & 255 & 255 & 255 & 350 & 140 & 350 & 140 & 197 & 197 & 140 \\
\hline 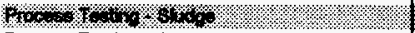 & on & 0 & 0 & \% & 4 & \% & 0 & xo & so & Xx & o. \\
\hline Process Testing - Supernatant & 0 & 250 & 0 & 250 & 250 & 250 & 250 & 250 & 0 & 0 & 0 \\
\hline $60 \% *$ & 10 & git & 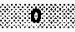 & \% & om & 6 & 0 & 如 & 8 & ox & 0 \\
\hline Historical Model Evaluation & o & 0 & 0 & 0 & 0 & 0 & 0 & 0 & 0 & 0 & 0 \\
\hline
\end{tabular}

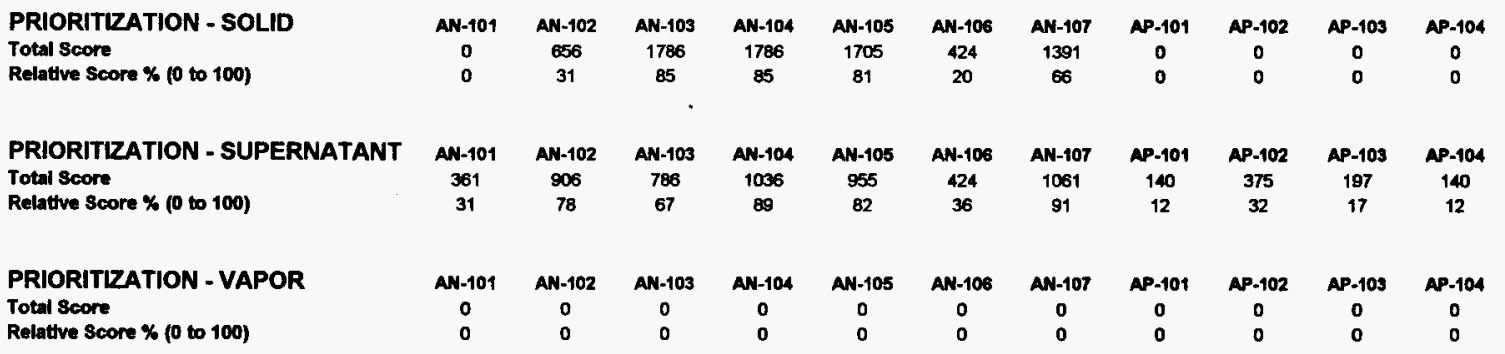


WHC-SD-WM-TA-164 Rev 2

\section{ISSUE PRIORITIES AND WEIGHTS}

\begin{tabular}{|c|c|c|c|c|c|c|c|c|c|c|c|}
\hline & AP-105 & AP-106 & AP-107 & AP-108 & $\begin{array}{c}\text { AW-101 } \\
x\end{array}$ & AW-102 & $\begin{array}{c}\text { AW-103 } \\
x\end{array}$ & $\begin{array}{c}\text { AW-104 } \\
\times\end{array}$ & $\begin{array}{c}\text { AW-105 } \\
x\end{array}$ & $\begin{array}{c}A W-106 \\
x\end{array}$ & $\begin{array}{c}\text { AY-101 } \\
x\end{array}$ \\
\hline & $x$ & $x$ & $x$ & $x$ & $x$ & $x$ & $\mathbf{x}$ & $\mathbf{x}$ & $x$ & $x$ & $x$ \\
\hline & $x$ & $x$ & $x$ & $\mathbf{x}$ & $x$ & $x$ & $\mathbf{x}$ & $x$ & $x$ & $\mathbf{x}$ & $\mathbf{x}$ \\
\hline Sosts & AP-405 & AP-106 & AP-107 & AP-108 & AW-101 & AW-102 & AW-103 & AW-104 & AW-105 & $A W-106$ & AY-101 \\
\hline Flammable Gas & 0 & 0 & 0 & $\mathbf{0}$ & 1000 & 0 & 0 & 580 & 0 & 0 & 400 \\
\hline 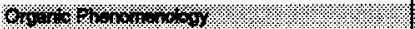 & \%o & 6ax & 8 & 6 & 4 & $\%$ & 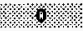 & 0 & 6. & 6. & 10 \\
\hline Safety Screening & 177 & 0 & 0 & 0 & 567 & 284 & 106 & 272 & 106 & 284 & 461 \\
\hline How ow & oi & 8 & 6 & 10 & 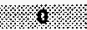 & o. & 0 & 4 & 8 & 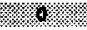 & 80 \\
\hline Vapor Space Phenomenology & 0 & 0 & 0 & 0 & $\mathbf{0}$ & 0 & 0 & 0 & 0 & 0 & 0 \\
\hline 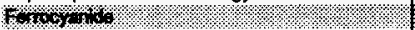 & 8 & 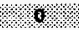 & 6 & 0 & 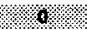 & 6 & 6 & \% & 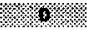 & 6 & 6 \\
\hline Privatization & 140 & 255 & 197 & 140 & 350 & 140 & 140 & 140 & 140 & 140 & 197 \\
\hline 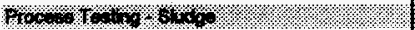 & $\mathbf{6}$ & m & 6 & o & 60 & \% & 6 & ox & 3 & 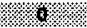 & 学 \\
\hline Process Testing - Supernatant & 250 & 0 & 0 & 0 & 250 & o & 100 & $\mathbf{0}$ & 100 & 0 & 0 \\
\hline Bhol & os & a & 6 & 0 & 6 & 6 & 6 & o & \% & \% & \% \\
\hline Historical Model Evaluation & 0 & $\mathbf{0}$ & 0 & 0 & 0 & 0 & 0 & 0 & 0 & o & 0 \\
\hline PRIORITIZATION - SOLID & AP-105 & AP-106 & AP-107 & AP-108 & AW-101 & AW-102 & AW-903 & AW-104 & $A W-106$ & AW-106 & AY-101 \\
\hline Total Score & 0 & 0 & $\mathbf{0}$ & 0 & 1917 & $\mathbf{0}$ & 246 & 992 & 246 & 424 & 1058 \\
\hline Relattve Score \% (0 to 100) & 0 & o & 0 & 0 & 91 & $\mathbf{0}$ & 12 & 47 & 12 & 20 & 50 \\
\hline PRIORITIZATION - SUPERNATANT & AP-105 & AP-106 & AP-107 & AP-108 & AW-101 & AW-102 & AW-103 & AW-104 & AW-106 & $A W-106$ & AY-101 \\
\hline Total score & 317 & 255 & 197 & 140 & 1167 & 424 & 346 & 412 & 346 & 424 & 658 \\
\hline Relattve Score \% (0 to 100) & 27 & 22 & 17 & 12 & 100 & 36 & 30 & 35 & 30 & 36 & 56 \\
\hline PRIORITIZATION - VAPOR & AP-105 & AP-106 & AP-107 & AP-108 & AW-101 & AW-102 & AW-103 & AW-104 & AW-105 & AW-106 & AY-101 \\
\hline Total score & 0 & 0 & 0 & 0 & 0 & 0 & 0 & 0 & 0 & 0 & 0 \\
\hline Relattve Score $\%(0$ to 100$)$ & 0 & 0 & 0 & 0 & 0 & 0 & 0 & 0 & 0 & 0 & 0 \\
\hline
\end{tabular}


WHC-SD-WM-TA-164 Rev 2

\section{ISSUE PRIORITIES AND WEIGHTS}

$\begin{array}{cccccc}A Y-102 & A Z-101 & A Z-102 & \text { SY-101 } & \text { SY-102 } & \text { SY-103 } \\ \times & X & X & X & X & X \\ X & \mathrm{X} & \mathrm{X} & \mathrm{X} & \mathrm{X} & \mathrm{X} \\ \mathrm{X} & \mathrm{X} & \mathrm{X} & \mathrm{X} & \mathrm{X} & \mathrm{X}\end{array}$

\begin{tabular}{|c|c|c|c|c|c|c|}
\hline 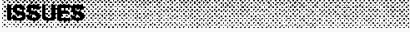 & AY-102 & AZ-101 & AZ-102 & SY-101 & SY-102 & SY-103 \\
\hline Flammable Gas & 0 & 0 & 0 & 1000 & 0 & 700 \\
\hline 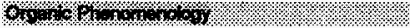 & \% & 8 & 0 & $\%$ & o & 6 \\
\hline Safety Screening & 106 & 284 & 106 & 567 & 284 & 343 \\
\hline 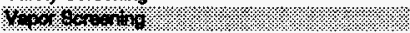 & w & \% & 6\% & (6) & 0 & Q \\
\hline Vapor Space Phenomenology & 0 & 0 & 0 & 0 & 0 & 0 \\
\hline Hor & 6 & o & 6 & 6 & \% & 6 6/ \\
\hline Privatization & 174 & 174 & 174 & 197 & 140 & 197 \\
\hline 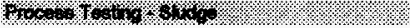 & so & 0 & 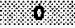 & $\%$ & $\alpha$ & 听 \\
\hline Process Testing - Supernatant & 0 & 175 & 175 & 0 & 0 & 0 \\
\hline Honst & \%o & 163 & 0 & 0 & o & 0 \\
\hline Historical Model Evaluation & 0 & 0 & 0 & 0 & 0 & 0 \\
\hline PRIORITIZATION - SOLID & AY-102 & AZ-101 & $A Z-102$ & SY-101 & SY-102 & SY-103 \\
\hline Total Score & 381 & 558 & 281 & 1765 & 424 & 1240 \\
\hline Relattve score \% (0 to 100) & 18 & 26 & 13 & 84 & 20 & 59 \\
\hline PRIORITIZATION - SUPERNATANT & AY-102 & AZ-101 & AZ-102 & SY-101 & SY-102 & SY-103 \\
\hline Total Score & 381 & 733 & 281 & 765 & 424 & 540 \\
\hline Relattve Score $\%(0$ to 100) & 33 & 63 & 24 & 65 & 36 & 46 \\
\hline PRIORITIZATION - VAPOR & AY-102 & AZ-101 & AZ-102 & 5Y-101 & SY-102 & SY-103 \\
\hline Total Score & 0 & 0 & 0 & $\mathbf{0}$ & D & 0 \\
\hline Relattve Score \% (0 to 100) & o & o & o & 0 & 0 & 0 \\
\hline
\end{tabular}


WHC-SD-WM-TA-164 Rev. 2

This page intentionally left blank. 
WHC-SD-WM-TA-164 Rev. 2

\section{APPENDIX F}

\section{CONSTRAINTS}


WHC-SD-WM-TA-164 Rev. 2

This page intentionally left blank. 
WHC-SD-WM-TA-164 Rev 2

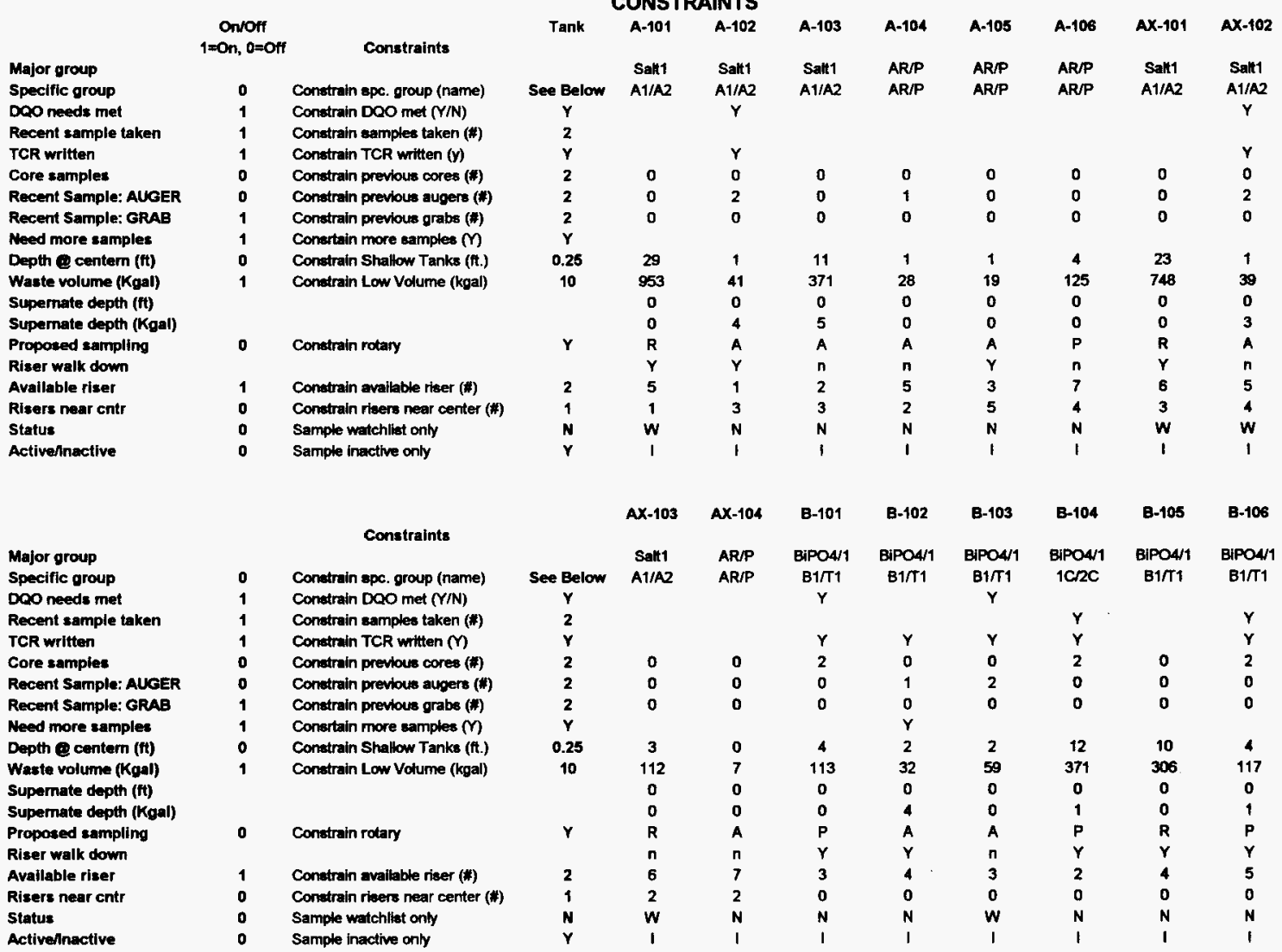


WHC-SD-WM-TA-164 Rev 2

\begin{tabular}{|c|c|c|c|c|c|c|c|c|c|c|c|c|c|}
\hline & & & & & & ONSTRA & NTS & & & & & & \\
\hline & B-107 & B-108 & B-109 & B-110 & B-111 & B-112 & B-201 & B-202 & B-203 & 8-204 & BX-101 & BX-102 & BX-103 \\
\hline Major group & BiPO4/1 & BIPO4/1 & BIPO4/1 & BipO4/1 & BiPO4/1 & BIPOAt & BIPO4/1 & BIPO4/1 & BiPO4/1 & BIPO4/1 & $\mathrm{BIPO} / 2$ & $D E$ & $\mathrm{BiPO} / / 2$ \\
\hline Speciflc group & $1 \mathrm{C} / 2 \mathrm{C}$ & $\mathrm{B} 1 / \mathrm{T1}$ & $\mathrm{B} 1 / \pi 1$ & $1 \mathrm{C} / 2 \mathrm{C}$ & $1 \mathrm{C} / 2 \mathrm{C}$ & $1 \mathrm{C} / 2 \mathrm{C}$ & 224 & 224 & 224 & 224 & MW & DE & MW \\
\hline DQO needs met & & & & & & $Y$ & & & $Y$ & $\mathbf{Y}$ & $Y$ & & \\
\hline Recent sample taken & & & & $\mathbf{Y}$ & $Y$ & & $Y$ & $\mathbf{Y}$ & & & & & \\
\hline TCR written & & & & $\mathbf{Y}$ & $\mathbf{Y}$ & $\mathbf{Y}$ & $\checkmark$ & $\mathbf{Y}$ & $Y$ & $\mathbf{Y}$ & $\mathbf{Y}$ & & $\mathbf{Y}$ \\
\hline Core samples & $\mathbf{0}$ & 0 & 0 & 8 & 2 & 0 & 2 & 2 & 2 & 2 & 0 & 0 & 2 \\
\hline Recent Sample: AUGER & 0 & 0 & 0 & 0 & 0 & 2 & 0 & 0 & 0 & 0 & 7 & 0 & 0 \\
\hline Recent Sample: GRAB & 0 & 0 & 0 & 0 & 0 & 0 & 0 & 0 & 0 & 0 & 0 & o & 0 \\
\hline Need more samples & & & & & & & & & & & & & $Y$ \\
\hline Depth e centem (it) & 6 & 3 & 4 & 8 & 8 & 2 & 13 & 12 & 22 & 22 & 2 & 4 & 3 \\
\hline Waste volume (Koal) & 165 & 94 & 127 & 246 & 237 & 33 & 29 & 27 & 51 & 50 & 43 & 96 & 66 \\
\hline Supernate depth (ft) & 0 & 0 & 0 & 0 & 0 & 0 & 0 & 0 & 0 & 0 & 0 & 0 & 0 \\
\hline Supamate depth (Koal) & 1 & 0 & 0 & 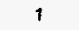 & 1 & 3 & 1 & 0 & 1 & 1 & 1 & 0 & 4 \\
\hline Proposed sampling & $\mathbf{R}$ & $\mathbf{P}$ & $\mathbf{P}$ & $\mathbf{P}$ & $\mathbf{P}$ & A & $\mathbf{P}$ & $\mathbf{P}$ & $\mathbf{P}$ & $\mathbf{P}$ & A & $\mathbf{R}$ & $P$ \\
\hline Riser walk down & $\mathbf{Y}$ & $\mathbf{Y}$ & $Y$ & $\mathbf{n}$ & $\mathbf{n}$ & $n$ & $n$ & n & $n$ & $n$ & $n$ & n & $Y$ \\
\hline Avallable riser & 4 & 3 & 4 & 3 & 5 & 6 & 4 & 6 & 6 & 6 & 2 & 2 & 2 \\
\hline Risers near cntr & 0 & 0 & 0 & 0 & $\mathbf{0}$ & 0 & 0 & D & $\mathbf{0}$ & 0 & 0 & 0 & 0 \\
\hline Status & $\mathbf{N}$ & $\mathbf{N}$ & $\mathbf{N}$ & $\mathbf{N}$ & $\mathbf{N}$ & $\mathbf{N}$ & $\mathbf{N}$ & $\mathbf{N}$ & $\mathbf{N}$ & $\mathbf{N}$ & $\mathbf{N}$ & $\mathbf{N}$ & $\mathbf{N}$ \\
\hline Active/lnactive & 1 & I & 1 & 1 & 1 & 1 & 1 & 1 & 1 & 1 & I & 1 & 1 \\
\hline & Ex-104 & BX-105 & BX-106 & BX-107 & $B X-108$ & BX-109 & BX-110 & $B X-111$ & BX-142 & BY-101 & BY-102 & BY-103 & BY-104 \\
\hline Major group & BIPOA/2 & BIPOA/2 & BIPOA/2 & BiPOA/1 & BiPO4/1 & BiPO4/2 & BIPO4/1 & Salt1 & BiPOA/1 & Salt1 & Salt1 & Salk1 & Salk1 \\
\hline Specific group & MW & MW & MW & $1 \mathrm{C} / 2 \mathrm{C}$ & $1 \mathrm{C} / 2 \mathrm{C}$ & UR & $1 \mathrm{C} / 2 \mathrm{C}$ & BY & $1 \mathrm{C} / 2 \mathrm{C}$ & BY & BY & BY & BY \\
\hline DQO needs met & $\mathbf{Y}$ & & $Y$ & & & & & & & & & & \\
\hline Recent sample taken & & $Y$ & & $\mathbf{Y}$ & $Y$ & $\mathbf{Y}$ & & & $Y$ & & $\mathbf{Y}$ & & $\mathbf{Y}$ \\
\hline TCR written & $Y$ & $Y$ & $\mathbf{Y}$ & $\mathbf{Y}$ & $\mathbf{Y}$ & $\mathbf{Y}$ & $\mathbf{Y}$ & & $\mathbf{Y}$ & & & & $Y$ \\
\hline Core samples & 2 & 0 & 0 & 2 & 0 & 2 & 0 & 0 & 2 & 0 & 0 & $\mathbf{0}$ & 2 \\
\hline Recent Sample: AUGER & 0 & 2 & 2 & 0 & 2 & & 2 & 0 & 2 & 0 & 0 & 2 & 0 \\
\hline Recent Sample: GRAB & 0 & 0 & 0 & 0 & 0 & & 0 & 0 & 0 & 0 & 0 & 0 & 0 \\
\hline Need more samples & & & & & & & $Y$ & & & & & $Y$ & \\
\hline Depth e centern (fi) & 4 & 2 & 2 & 11 & 1 & 6 & 7 & 6 & 6 & 12 & 11 & 13 & 13 \\
\hline Waste volume (Kgal) & 99 & 51 & 46 & 345 & 26 & 193 & 207 & 162 & 165 & 387 & 341 & 400 & 406 \\
\hline Supernate depth (it) & 0 & o & 0 & $\mathbf{0}$ & 0 & 0 & 0 & $\mathbf{0}$ & 0 & 0 & 0 & 0 & 0 \\
\hline Supernate depth (Kgal) & 3 & 5 & 15 & 1 & 0 & 0 & 3 & 1 & 1 & 0 & 0 & o & 0 \\
\hline Proposed sampling & $\mathbf{P}$ & A & A & $\mathbf{P}$ & A & $\mathbf{P}$ & $\mathbf{R}$ & $\mathbf{R}$ & $\mathbf{P}$ & $\mathbf{R}$ & $\mathbf{R}$ & $\mathbf{R}$ & $\mathbf{R}$ \\
\hline Riser walk down & n & n & $Y$ & $n$ & $n$ & $Y$ & $Y$ & $n$ & $\mathbf{n}$ & $n$ & $n$ & $Y$ & $Y$ \\
\hline Available riser & 2 & 3 & 2 & 5 & 4 & 3 & 4 & 3 & 4 & 5 & 4 & 4 & 3 \\
\hline Risers near cntr & 0 & 0 & 0 & 0 & 1 & 0 & 0 & 0 & 0 & 0 & 2 & 0 & 2 \\
\hline Status & $\mathbf{N}$ & $\mathbf{N}$ & $\mathbf{N}$ & $\mathbf{N}$ & $\mathbf{N}$ & $\mathbf{N}$ & $\mathbf{N}$ & $\mathbf{N}$ & $\mathbf{N}$ & $\mathbf{N}$ & $\mathbf{N}$ & $w$ & $w$ \\
\hline Active/nactive & I & 1 & I & 1 & 1 & 1 & 1 & 1 & 1 & i & 1 & $i$ & 1 \\
\hline
\end{tabular}


WHC-SD-WM-TA-164 Rev 2

\begin{tabular}{|c|c|c|c|c|c|c|c|c|c|c|c|c|c|}
\hline & & & & & & ONSTR & INTS & & & & & & \\
\hline & BY-105 & BY.106 & BY-107 & BY-108 & BY.109 & BY-110 & BY-111 & BY-112 & C-101 & C-102 & C-103 & C-104 & C-10s \\
\hline Major group & Saltt & Salt1 & Salt1 & Salt1 & Salt1 & Salt1 & Salt1 & Salk1 & BiPO4/2 & CWAI & CWAI & CWAI & CWAI \\
\hline Specific group & BY & BY & BY & BY & BY & BY & or & BY & UR & CWP & CWP & CWP & CWP \\
\hline DOO needs met & & & & $Y$ & & & & & & & $Y$ & & $Y$ \\
\hline Recent sample taken & $r$ & & $Y$ & & & $\mathbf{Y}$ & & & & & & & \\
\hline TCR written & $Y$ & $\mathbf{Y}$ & & $Y$ & & $Y$ & & & $Y$ & & $\mathbf{Y}$ & & $\mathbf{Y}$ \\
\hline Core samples & 0 & 1 & 0 & 3 & 0 & 4 & 0 & 0 & & & 2 & 0 & 2 \\
\hline Recent Sample: AUGER & 0 & 0 & 0 & 2 & 0 & 0 & 0 & 0 & 2 & 1 & $\mathbf{0}$ & 0 & 2 \\
\hline Recent Sample: GRAB & 0 & 0 & 0 & 1 & 0 & 0 & 0 & 0 & 0 & $\mathbf{0}$ & 0 & 0 & o \\
\hline Need more samples & & $\mathbf{Y}$ & & & & & & & $\mathbf{Y}$ & $\mathbf{Y}$ & & & \\
\hline Depth \& centern ( $f$ ) & 16 & 20 & 9 & 8 & 13 & 13 & 15 & $\mathbf{9}$ & 3 & 13 & 7 & 10 & $\dot{5}$ \\
\hline Waste volume (Kgal) & 503 & 642 & 266 & 228 & 423 & 398 & 459 & 291 & 88 & 423 & 195 & 295 & 135 \\
\hline Supernate depth (ft) & 0 & 0 & 0 & 0 & 0 & 0 & o & 0 & 0 & 0 & 4 & 0 & 0 \\
\hline Supernate depth (Kgal) & 0 & 0 & 0 & 0 & 0 & 0 & 0 & 0 & 0 & 0 & .133 & 0 & 5 \\
\hline Proposed sampling & $\mathbf{R}$ & $\mathbf{R}$ & $\mathrm{R}$ & $\mathbf{R}$ & $\mathbf{R}$ & $\mathbf{R}$ & $\mathbf{R}$ & $\mathbf{R}$ & A & $\mathbf{R}$ & $P$ & $\mathbf{R}$ & $\mathbf{p}$ \\
\hline Riser walk down & $\mathbf{Y}$ & $\mathbf{Y}$ & $Y$ & $Y$ & $Y$ & $\mathbf{Y}$ & $Y$ & $\mathbf{Y}$ & $Y$ & $\mathbf{Y}$ & $\mathbf{Y}$ & $\mathbf{Y}$ & $n$ \\
\hline Available riser & 3 & 2 & 5 & 3 & 4 & 3 & 2 & 4 & 2 & 2 & 2 & 2 & 2 \\
\hline Risers near cntr & 1 & 1 & 3 & 3 & 0 & 3 & 1 & 1 & o & 0 & D & 0 & 0 \\
\hline Status & $w$ & $\mathbf{w}$ & $w$ & $\mathbf{w}$ & $\mathbf{N}$ & $w$ & $w$ & $w$ & $\mathbf{N}$ & $\mathbf{w}$ & $w$ & $\mathbf{N}$ & $\mathbf{N}$ \\
\hline Active/nactive & 1 & 1 & 1 & 1 & 1 & $\mathbf{I}$ & $\mathbf{I}$ & 1 & 1 & 1 & 1 & 1 & 1 \\
\hline & C.106 & C-107 & C-108 & C-109 & C-110 & C.111 & C-112 & $C-201$ & C-202 & $C-203$ & C-204 & S-101 & S-102 \\
\hline Major group & AR/P & BIPO4/1 & BIPO $4 / 2$ & $\mathrm{BIPO} 4 / 2$ & BIPO4/1 & BIPO4/1 & BIPO $4 / 2$ & BIPO4/2 & BIPO4/2 & BIPOA/2 & BIPO4/2 & Redox & Salt2 \\
\hline Specific group & AR/P & $1 \mathrm{C} / 2 \mathrm{C}$ & UR & $\mathrm{FeCN}$ & $1 \mathrm{C} / 2 \mathrm{C}$ & $1 \mathrm{C} / 2 \mathrm{C}$ & $\mathrm{FeCN}$ & MW & $M W$ & MW & MW & R1 & $\mathbf{S 1 / S 2}$ \\
\hline DeO needs met & & $r$ & $Y$ & $Y$ & $Y$ & $Y$ & $Y$ & & & $\mathbf{Y}$ & $Y$ & & \\
\hline Recent sumple taken & & & & & & & & & & & & $\mathbf{r}$ & $Y$ \\
\hline TCR written & $\mathbf{Y}$ & $\mathbf{r}$ & $\mathbf{Y}$ & $\mathbf{Y}$ & $\mathbf{Y}$ & $\mathbf{Y}$ & $\mathbf{r}$ & $Y$ & $Y$ & $\mathbf{Y}$ & $\mathbf{Y}$ & $r$ & $\mathbf{Y}$ \\
\hline Core sample: & 0 & 3 & 1 & 3 & 3 & 3 & 3 & $\mathbf{0}$ & $\mathbf{0}$ & 0 & 0 & o & 0 \\
\hline Recant Sample: AUGER & 0 & 0 & 2 & 0 & 0 & 2 & 0 & 2 & 2 & 2 & 2 & 0 & 0 \\
\hline Recent Sample: GRAB & $\mathbf{0}$ & $\mathbf{0}$ & 0 & 0 & 0 & 0 & 0 & $\mathbf{0}$ & $\mathbf{0}$ & 0 & 0 & $\mathbf{0}$ & 0 \\
\hline Nead more samples & $\mathbf{r}$ & & & & & & & 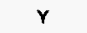 & $Y$ & & & & \\
\hline Depth $\mathrm{e}$ centern ( $\mathrm{f}$ ) & 8 & 9 & 3 & 3 & 6 & 2 & 4 & 1 & 1 & 2 & 2 & 14 & 17 \\
\hline Waste volume (Kgal) & 229 & 275 & 66 & 66 & 187 & 57 & 104 & 2 & 1 & 5 & 3 & 427 & 549 \\
\hline Supernate depth (ft) & 1 & 0 & 0 & 0 & 0 & 0 & 0 & 0 & 0 & 0 & $\mathbf{0}$ & o & 0 \\
\hline Supernate depth (Kgal) & 32 & 0 & 0 & 4 & 0 & 0 & 0 & 0 & 0 & 0 & o & 12 & o \\
\hline Proposed sampling & $\mathbf{P}$ & $\mathbf{P}$ & $A$ & $\mathbf{p}$ & $\mathbf{P}$ & $\mathbf{P}$ & $\mathbf{P}$ & A & A & A & A & $\mathbf{R}$ & $\mathbf{R}$ \\
\hline Riser walk down & $n$ & $Y$ & $n$ & n & $n$ & $n$ & $n$ & $n$ & $\mathbf{n}$ & $\mathrm{n}$ & $n$ & $Y$ & $\mathbf{Y}$ \\
\hline Available riser & 3 & 4 & 5 & 5 & 6 & 6 & 5 & 2 & 2 & 2 & 2 & 4 & 5 \\
\hline Risers near cntr & 0 & 0 & 0 & 0 & 0 & 0 & 0 & 0 & o & 0 & o & 4 & 3 \\
\hline Status & $w$ & $\mathbf{N}$ & $w$ & $\mathbf{w}$ & $\mathbf{N}$ & $\mathbf{w}$ & $w$ & $\mathbf{N}$ & $\mathbf{N}$ & $\mathbf{N}$ & $\mathbf{N}$ & $\mathbf{N}$ & $\mathbf{w}$ \\
\hline Active/nactive & 1 & 1 & 1 & 1 & I & $\mathbf{I}$ & $\mathbf{I}$ & 1 & 1 & I & 1 & 1 & 1 \\
\hline
\end{tabular}


WHC-SD-WM-TA-164 Rev 2

\begin{tabular}{|c|c|c|c|c|c|c|c|c|c|c|c|c|c|}
\hline & & & & & & DNSTR & INTS & & & & & & \\
\hline & S-103 & 5-104 & S-10s & S-106 & S-107 & S-108 & S-109 & $5-110$ & S-111 & S-112 & $5 x-101$ & sX-102 & sx-103 \\
\hline Major group & Salt2 & Redox & Salt2 & Salt2 & Redox & Salt2 & Salk2 & Salt2 & Salie & Salt2 & Redox & Sent2 & Salt2 \\
\hline Specific group & s1/s2 & R1 & $\$ 1 / s 2$ & $s 1 / s 2$ & R1 & $\mathbf{s 1 / s 2}$ & $s 1 / 52$ & $\mathbf{s 1 / s 2}$ & $51 / 52$ & $s 1 / s_{2}$ & R1 & $\mathbf{s} 1 / \mathrm{s} 2$ & $s 1 / s 2$ \\
\hline DoO needs met & & & & & & & & & & & & & \\
\hline Recent sample taken & & $\mathbf{Y}$ & & & $\mathbf{Y}$ & & $Y$ & $\mathbf{Y}$ & $\mathbf{Y}$ & & & & \\
\hline TCR written & & $\mathbf{Y}$ & & & $\mathbf{Y}$ & & & & & & & & \\
\hline Core samples & 0 & 3 & 0 & 0 & 3 & $\mathbf{0}$ & $\mathbf{0}$ & 0 & 0 & 0 & 0 & 0 & 0 \\
\hline Recent Sample: AUGER & 0 & 0 & 0 & 0 & 0 & 0 & o & 0 & 0 & 0 & 0 & 0 & 0 \\
\hline Recent Sample: GRAB & 0 & 0 & 0 & 0 & 0 & 0 & 0 & 0 & 0 & 0 & 0 & 0 & 0 \\
\hline Need more ramples & & & & & & & & & $Y$ & & & & \\
\hline Depth Q centern (it) & 8 & 10 & 14 & 15 & 12 & 19 & 18 & 12 & 19 & 16 & 14 & 17 & 20 \\
\hline Waste volume (Kgal) & 248 & 294 & 456 & 479 & 376 & 604 & 568 & 390 & 596 & 523 & 456 & 543 & 652 \\
\hline Supernate depth (ft) & 1 & 0 & 0 & 0 & 0 & 0 & 0 & 0 & 0 & 0 & 0 & 0 & 0 \\
\hline Supemate depth (Kgal) & 17 & 1 & 0 & 4 & 14 & 0 & 0 & 0 & 10 & 0 & 1 & 0 & 1 \\
\hline Proposed sampling & $\mathbf{R}$ & $\mathbf{p}$ & $R$ & $\mathbf{R}$ & p & $\mathbf{R}$ & $\mathbf{R}$ & $\mathbf{R}$ & $\mathbf{P}$ & $\mathbf{R}$ & $\mathbf{R}$ & $\mathbf{R}$ & $\mathbf{R}$ \\
\hline Riser walk down & $n$ & $\mathbf{n}$ & n & n & $\mathbf{Y}$ & $n$ & $\mathbf{n}$ & $\mathbf{Y}$ & n & $n$ & $\mathbf{Y}$ & $Y$ & $Y$ \\
\hline Available riser & 5 & 4 & 5 & 5 & 5 & 4 & 5 & 4 & 4 & 5 & 2 & 3 & 4 \\
\hline Risers near cntr & 3 & 4 & 4 & 2 & 3 & 2 & 2 & 4 & 2 & 3 & 1 & 2 & 2 \\
\hline Status & $\mathbf{N}$ & $\mathbf{N}$ & $\mathbf{N}$ & $\mathbf{N}$ & $\mathbf{N}$ & $\mathbf{N}$ & $\mathbf{N}$ & $\mathbf{N}$ & $w$ & $w$ & $w$ & $w$ & $w$ \\
\hline Active/nactive & 1 & I & 1 & 1 & 1 & 1 & 1 & I & 1 & 1 & 1 & 1 & 1 \\
\hline & $5 x-104$ & $5 x-105$ & $5 x-106$ & sx-107 & $5 x-108$ & $5 x-109$ & $s x-110$ & $5 x-111$ & $5 x-112$ & $5 x-113$ & $5 x-114$ & $s x-116$ & $T-101$ \\
\hline Major group & Salt2 & Salt2 & Salt2 & Redox & Redox & Redox & Redox & Redox & Redox & DE & Redox & Redox & Salk2 \\
\hline Specific group & $\mathbf{s 1 / 5 2}$ & $\mathrm{s}_{1 / \mathrm{s} 2}$ & $\mathrm{~s} 1 / \mathrm{s} 2$ & R1 & R1 & RSHCK & RSHCK & RSItCK & RSHCK & $\mathrm{DE}$ & RSICKK & RSHCK & $\mathrm{T} 2$ \\
\hline DQO needs met & & & & & & & & & & $Y$ & & & \\
\hline Recent sample taken & & & & & & & & & & & & & \\
\hline TCR written & & & & & $\mathbf{Y}$ & & & & & $Y$ & & & \\
\hline Core samples & 0 & 0 & 0 & 0 & 0 & 0 & 0 & 0 & 0 & 0 & 0 & 0 & 0 \\
\hline Recent Sample: AUCER & 0 & o & 0 & 0 & 2 & 0 & 0 & 0 & 0 & 2 & 0 & 2 & 0 \\
\hline Recent Sample: GRAB & 0 & 0 & 0 & 0 & 0 & 0 & 0 & 0 & 0 & 0 & 0 & 0 & 0 \\
\hline Need more sexmples & & & & & $\mathbf{Y}$ & & & & & & & & \\
\hline Depth e centem (ft) & 19 & 21 & 17 & 4 & 3 & 8 & 2 & 4 & 3 & 1 & 6 & 1 & 4 \\
\hline Waste volume (Kgal) & 614 & 683 & 538 & 104 & 87 & 250 & 62 & 125 & 92 & 26 & 181 & 12 & 102 \\
\hline Supemate depth (ft) & 0 & 0 & 2 & 0 & $\mathbf{0}$ & D & 0 & $\mathbf{0}$ & 0 & 0 & 0 & 0 & 0 \\
\hline Supermate depth (Kgal) & 0 & 0 & 61 & 0 & 0 & 0 & 0 & 0 & 0 & 0 & 0 & 0 & 1 \\
\hline Proposed sampling & $\mathbf{R}$ & $\mathbf{R}$ & $\mathbf{R}$ & $\mathbf{R}$ & $\mathbf{R}$ & $\mathbf{R}$ & $\mathbf{R}$ & $\mathbf{R}$ & $\mathbf{R}$ & A & $\mathbf{R}$ & $A$ & $\mathbf{R}$ \\
\hline Riser walk down & Y & $\dot{Y}$ & $Y$ & $n$ & 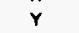 & 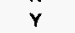 & $n$ & $n$ & $n$ & $n$ & $n$ & $n$ & $n$ \\
\hline Avallable riser & 3 & 4 & 2 & 4 & 4 & 3 & 3 & 5 & 2 & 2 & 3 & 2 & 2 \\
\hline Risers near cntr & 3 & 2 & 2 & 3 & 3 & 2 & 2 & 3 & 1 & 2 & 2 & 1 & 0 \\
\hline Status: & $w$ & $w$ & $w$ & $\mathbf{N}$ & N & $\bar{w}$ & $\mathbf{N}$ & $\mathbf{N}$ & $\mathbf{N}$ & $\mathbf{N}$ & $\mathbf{N}$ & $\mathbf{N}$ & $\mathbf{N}$ \\
\hline Active/nactive & I & $\mathbf{I}$ & 1 & 1 & I & 1 & I & 1 & 1 & .1 & 1 & 1 & 1 \\
\hline
\end{tabular}




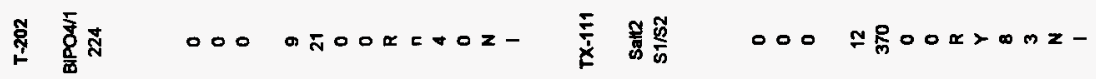

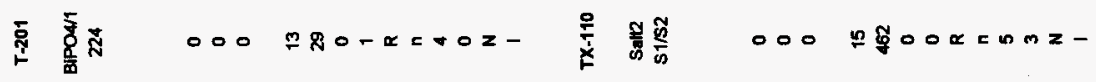

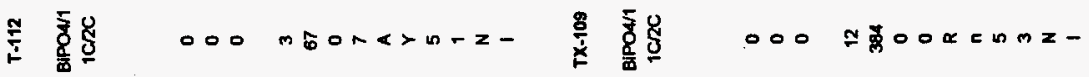

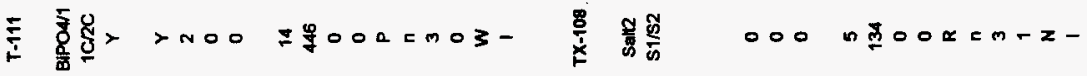

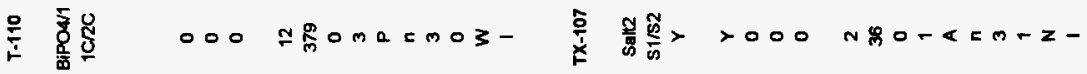

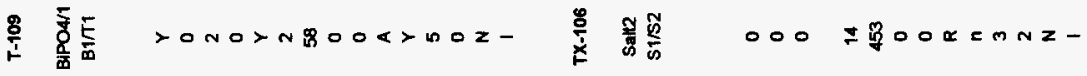

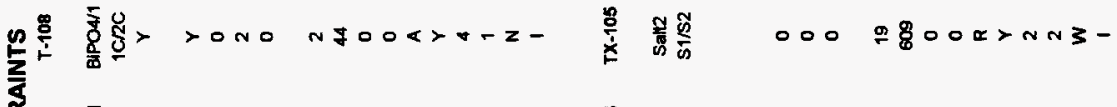

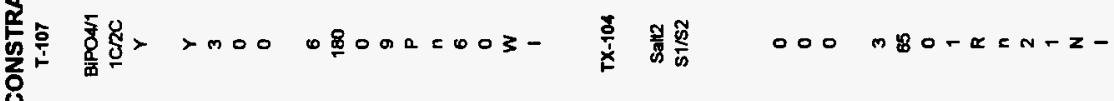

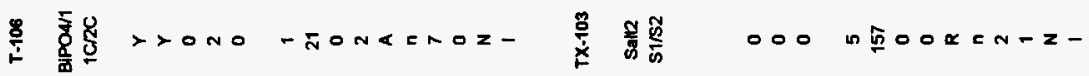

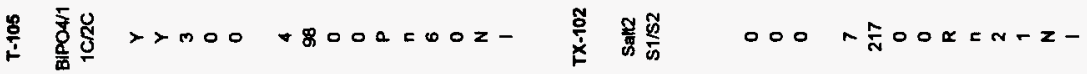

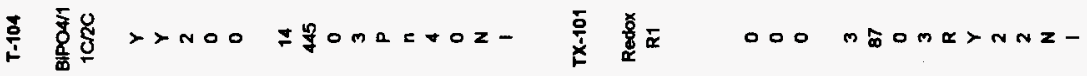

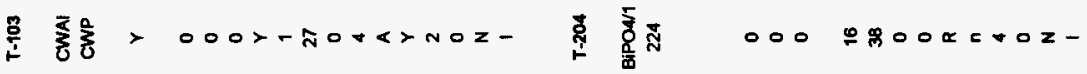

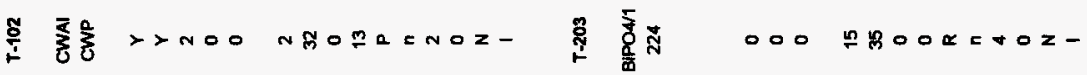
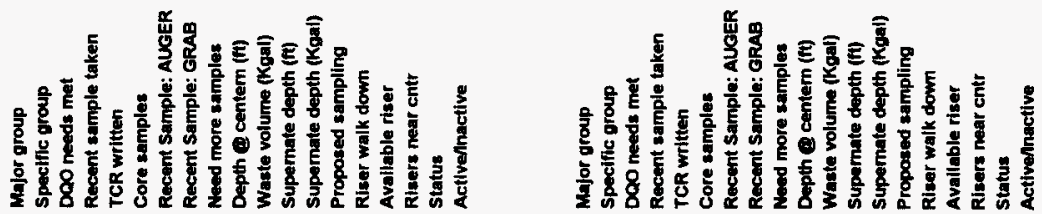
WHC-SD-WM-TA-164 Rev 2

\begin{tabular}{|c|c|c|c|c|c|c|c|c|c|c|c|c|c|}
\hline & \multicolumn{10}{|c|}{ CONSTRAINTS } & \multirow[b]{2}{*}{ TY-104 } & \multirow[b]{2}{*}{ TY-105 } & \multirow[b]{2}{*}{$T r-106$} \\
\hline & $T X-112$ & $T X-113$ & $T X-114$ & TX-115 & $T X-116$ & $T X-117$ & $T X-1+8$ & Tr-101 & TY-102 & $T Y-103$ & & & \\
\hline Major group & Salt2 & Salt & Salt2 & Salt2 & Salt2 & Salt2 & Salt2 & BiPO4/2 & Salk & BIPO4/2 & BIPO4/2 & BIPOA/2 & BiPO4/2 \\
\hline $\begin{array}{l}\text { Specific group } \\
\text { DQO needs met } \\
\text { Recent sample taken }\end{array}$ & $s 1 / s 2$ & $\mathrm{~s} 1 / \mathrm{s} 2$ & $s 1 / s 2$ & s1/s2 & $51 / s_{2}$ & $s 1 / s 2$ & $s 1 / s 2$ & FeCN & $T 2$ & UR & $\begin{array}{l}\text { UR } \\
Y\end{array}$ & UR & $\begin{array}{l}\text { UR } \\
Y\end{array}$ \\
\hline TCR written & & & & & & & & & & & $Y$ & & $\mathbf{Y}$ \\
\hline Core samples & 0 & 0 & 0 & 0 & 0 & 0 & 0 & 0 & 0 & $\mathbf{0}$ & 2 & 0 & 0 \\
\hline Recent Sample: AUGER & 0 & 0 & 0 & 0 & 0 & 0 & 0 & 0 & 0 & 0 & 2 & 0 & 2 \\
\hline Recent Sample: GRAB & 0 & 0 & 0 & 0 & 0 & 0 & 0 & 0 & 0 & $\mathbf{0}$ & 0 & 0 & 0 \\
\hline \multicolumn{14}{|l|}{ Need more samples } \\
\hline Depth centem (ft) & 20 & 19 & 17 & 20 & 20 & 20 & 11 & 4 & 3 & 6 & 2 & 8 & 1 \\
\hline Waste volume (Kgal) & 649 & 607 & 535 & 640 & 631 & 626 & 347 & 118 & 64 & 162 & 46 & 231 & 17 \\
\hline Supernate depth (ft) & 0 & 0 & 0 & 0 & 0 & 0 & 0 & 0 & 0 & 0 & 0 & 0 & 0 \\
\hline Supernate depth (Kgal) & 0 & 0 & 0 & 0 & 0 & 0 & 0 & 0 & 0 & 0 & 3 & 0 & 0 \\
\hline Proposed sampling & $R$ & $\mathbf{R}$ & $\mathbf{R}$ & $\mathbf{R}$ & $\mathbf{R}$ & $\mathbf{R}$ & $\mathbf{R}$ & $R$ & $\mathbf{R}$ & $\mathbf{R}$ & P & $\mathbf{R}$ & $A$ \\
\hline Riser walk dowm & $\gamma$ & $n$ & $n$ & n & $Y$ & $n$ & $Y$ & $Y$ & $Y$ & $Y$ & $n$ & $n$ & $n$ \\
\hline Avallable riser & 5 & 3 & 5 & 5 & 4 & 5 & 8 & 2 & 2 & 2 & 6 & 4 & 6 \\
\hline Risers near cntr & 2 & 2 & 3 & 2 & 3 & 2 & 2 & 3 & 3 & 3 & 2 & 3 & 1 \\
\hline Status & $\mathrm{N}$ & $\mathrm{N}$ & $\mathbf{N}$ & $\mathrm{N}$ & $\mathbf{N}$ & $\mathbf{N}$ & $w$ & $w$ & $\mathbf{N}$ & $w$ & $w$ & $\mathbf{N}$ & $\mathrm{N}$ \\
\hline \multirow[t]{2}{*}{ Active/nactive } & 1 & I & 1 & 1 & 1 & 1 & 1 & i & 1 & $i$ & 1 & $i$ & 1 \\
\hline & U-101 & U-102 & U-103 & U-104 & $U-106$ & $U-106$ & U-107 & $U-108$ & U-109 & U-110 & $U-111$ & U-112 & U-201 \\
\hline Major group & BiPO4/2 & Salt2 & Salt2 & DE & Salt2 & Salt2 & Salt2 & Salle & Salt2 & BiPO4/1 & Salt2 & BIPOA/1 & Redox \\
\hline Specific group & MW & $\mathrm{T} 2$ & $s 1 / s 2$ & $\mathrm{DE}$ & $\mathbf{s 1 / s 2}$ & s1/s2 & $s 1 / s 2$ & $s 1 / s 2$ & s1/s2 & $1 \mathrm{C} / 2 \mathrm{C}$ & $s 1 / s 2$ & $1 \mathrm{C} 2 \mathrm{C}$ & CWR \\
\hline DCO needs met & & & & & & & & & & & & & $Y$ \\
\hline Recent sample taken & $\mathbf{Y}$ & $\mathbf{r}$ & & & $\gamma$ & $\mathbf{Y}$ & $\mathbf{Y}$ & $\mathbf{Y}$ & $\mathbf{Y}$ & $Y$ & & & \\
\hline TCR written & & & & & $\mathbf{r}$ & & $Y$ & & $\gamma$ & $y$ & & & $\gamma$ \\
\hline Core samples & 0 & 0 & 0 & 0 & 0 & 0 & 0 & 0 & 0 & 8 & 0 & 0 & 3 \\
\hline Recent Sample: AUGER & 0 & 0 & o & 0 & 0 & 0 & 0 & 0 & 0 & 0 & D & 0 & 0 \\
\hline $\begin{array}{l}\text { Recent Sample: GRAB } \\
\text { Need more samples }\end{array}$ & 0 & 0 & 0 & 0 & 0 & 0 & 0 & 0 & . 0 & 0 & 0 & 0 & 0 \\
\hline Depth centem (ft) & 1 & 12 & 15 & 4 & 13 & 7 & 13 & 15 & 15 & 6 & 11 & 2 & 2 \\
\hline Waste volume (Kgal) & 25 & 374 & 468 & 122 & 418 & 226 & 406 & 468 & 463 & 186 & 329 & 49 & 5 \\
\hline Supernate depth (it) & 0 & 1 & 0 & 0 & 1 & 0 & 1 & 1 & 1 & 0 & 0 & 0 & 0 \\
\hline Supernate depth (Kgal) & 3 & 18 & 13 & 0 & 37 & 15 & 31 & 24 & 19 & 0 & D & 4 & 1 \\
\hline Proposed sampling & A & $\mathbf{R}$ & $\mathbf{R}$ & $\mathbf{R}$ & $\mathbf{R}$ & $R$ & $\mathbf{R}$ & $\mathbf{R}$ & $\mathbf{R}$ & $\mathbf{R}$ & $\mathbf{R}$ & $\mathbf{R}$ & $\mathbf{P}$ \\
\hline Riser watk down & $n$ & n & $n$ & $n$ & $r$ & $Y$ & $y$ & $Y$ & $\gamma$ & $n$ & $Y$ & r & 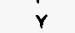 \\
\hline Available riser & 2 & 3 & 3 & 3 & 3 & 3 & 4 & 4 & 4 & 5 & 5 & 4 & 2 \\
\hline Risers near cntr & 0 & o & 0 & 0 & 0 & 0 & 0 & 0 & 0 & 0 & 0 & 0 & 0 \\
\hline Status & $\mathbf{N}$ & $\mathbf{N}$ & $w$ & $\mathbf{N}$ & $w$ & $w$ & $w$ & $w$ & $w$ & $\mathbf{N}$ & $w$ & $\mathbf{N}$ & $\mathrm{N}$ \\
\hline Active/nactive & 1 & 1 & 1 & 1 & 1 & 1 & 1 & 1 & 1 & 1 & 1 & 1 & 1 \\
\hline
\end{tabular}


WHC-SD-WM-TA-164 Rev 2

\begin{tabular}{|c|c|c|c|c|c|c|c|c|c|c|c|c|c|}
\hline \multicolumn{14}{|c|}{ CONSTRAINTS } \\
\hline & U-202 & U-203 & U-204 & AN-101 & AN-102 & AN-103 & AN-104 & AN-105 & AN-106 & AN-107 & AP-101 & AP-102 & AP-103 \\
\hline Major group & Redox & Redox & Redox & & Others & Salt1 & Salt1 & & Salt1 & Others & Others & Others & Others \\
\hline Specific group & CWR & CWR & CWR & & Others & $\mathbf{A} 1 / \mathbf{A} 2$ & $A 1 / A 2$ & & $A 1 / A 2$ & Others & Others & Others & Others \\
\hline DQO needs mèt & $\mathbf{Y}$ & $Y$ & $\mathbf{Y}$ & & & & & & $Y$ & & & & \\
\hline Recent sample taken & & & & $\mathbf{Y}$ & $\mathbf{Y}$ & & & $\mathbf{Y}$ & & $\mathbf{Y}$ & $\mathbf{Y}$ & $\mathbf{Y}$ & $\mathbf{Y}$ \\
\hline TCR written & $\mathbf{Y}$ & $\mathbf{Y}$ & $\mathbf{Y}$ & $\mathbf{Y}$ & $Y$ & & & & $\mathbf{r}$ & $\mathbf{Y}$ & $Y$ & $Y$ & $Y$ \\
\hline Core samples & 2 & 2 & 2 & 0 & 1 & 0 & 0 & 0 & 0 & 0 & 0 & 0 & 0 \\
\hline Recent Sample: AUGER & 0 & 0 & 0 & $\mathbf{0}$ & $\mathbf{0}$ & 0 & 0 & 0 & 0 & 0 & 0 & 0 & 0 \\
\hline Recent Sample: GRAB & 0 & 0 & 0 & 2 & 4 & 0 & 0 & 0 & 0 & 4 & 5 & 15 & 9 \\
\hline \multicolumn{14}{|l|}{ Need more samples } \\
\hline Depth e centern (ft) & 2 & 2 & 2 & 27 & 33 & 29 & 32 & 34 & 13 & 32 & 2 & 33 & 1 \\
\hline Waste volume (Kgal) & 5 & 3 & 3 & 903 & 1082 & 951 & 1058 & 1130 & 420 & 1058 & 78 & 1099 & 26 \\
\hline Supernate depth (ft) & 0 & 0 & 0 & 27 & 30 & 0 & 24 & 34 & 12 & 28 & 2 & 33 & 1 \\
\hline Supermate depth (Kgal) & 1 & 1 & 1 & 903 & 993 & 14 & 794 & 1130 & 400 & 924 & 78 & 1099 & 26 \\
\hline Proposed sampling & $\mathbf{P}$ & A & $\mathbf{P}$ & $\mathbf{G}$ & $\mathbf{P}$ & $P$ & $P$ & $\mathbf{P}$ & G & $\mathbf{G}$ & $G$ & $\mathbf{G}$ & $\mathbf{G}$ \\
\hline Riser walk down & $\mathbf{Y}$ & $\mathbf{Y}$ & $Y$ & & & & & & & & & & \\
\hline Avallabie riser & 2 & 2 & 2 & 5 & 6 & 6 & 6 & 6 & 6 & 6 & 11 & 12 & 13 \\
\hline Risers near cntr & 0 & 0 & 0 & 1 & 2 & 2 & 2 & 3 & 2 & 3 & 6 & 6 & 6 \\
\hline Status & $\mathbf{N}$ & $w$ & $w$ & $\mathbf{N}$ & $\mathrm{N}$ & $w$ & $w$ & $w$ & $\mathbf{N}$ & $\mathbf{N}$ & $\mathbf{N}$ & $\mathbf{N}$ & $\mathrm{N}$ \\
\hline \multirow[t]{2}{*}{ Active/nactive } & 1 & 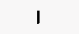 & 1 & A & 1 & I & 1 & 1 & 1 & 1 & A & 1 & 1 \\
\hline & AP-104 & AP-105 & AP-106 & AP-107 & AP-10B & AW-101 & AW-102 & AW-103 & AW-104 & $A W-105$ & AW-106 & AY-101 & AY -102 \\
\hline Major group & Others & Others & Others & Others & Others & Salt1 & Salt1 & $\mathrm{cWZr}$ & Salt1 & CWZr & Salt1 & Others & Others \\
\hline Specific group & Others & Others & Others & Others & Others & A1/A2 & At/A2 & CWRr & $\mathrm{A} 1 / \mathrm{A} 2$ & CWZr & $A 1 / A 2$ & Others & Others \\
\hline DCO needs met & & & & & $Y$ & & & & & & & & \\
\hline Recent sample taken & $\mathbf{Y}$ & $\mathbf{Y}$ & & $\mathbf{Y}$ & & $Y$ & & $Y$ & & & & $\mathbf{Y}$ & \\
\hline TCR written & $\mathbf{Y}$ & $Y$ & $Y$ & $Y$ & $\mathbf{Y}$ & $\mathbf{Y}$ & $\mathbf{Y}$ & $Y$ & $\mathbf{Y}$ & $\mathbf{Y}$ & $\mathbf{Y}$ & $Y$ & $\mathbf{Y}$ \\
\hline Core samples & 0 & 0 & 0 & 0 & 0 & 0 & 0 & 0 & & 1 & 0 & 0 & 0 \\
\hline Recent Sample: AUGER & 0 & 0 & 0 & 0 & 0 & 3 & & 3 & & 0 & 0 & & 0 \\
\hline Recent Sample: GRAB & 0 & 0 & 7 & 6 & 2 & 0 & & & & 0 & 0 & & 0 \\
\hline Need more samples & & & $\mathbf{Y}$ & & & & $\mathbf{Y}$ & & $\mathbf{Y}$ & $\mathbf{Y}$ & $Y$ & & $Y$ \\
\hline Depth \& centem (it) & 1 & 25 & 32 & 30 & 1 & 34 & 5 & 16 & 34 & 13 & 20 & 27 & 26 \\
\hline Waste volume (Kgal) & 18 & 818 & 1043 & 996 & 28 & 1124 & 174 & 515 & 1124 & 413 & 655 & 881 & 848 \\
\hline Supernate depth (ft) & 1 & 25 & 32 & 30 & 1 & 32 & 5 & 5 & 25 & 4 & 11 & 24 & 25 \\
\hline Supemate depth (Kga) & 18 & 818 & 1043 & 996 & 28 & 1040 & 173 & 152 & 834 & 116 & 359 & 798 & 816 \\
\hline Proposed sampling & $\mathbf{G}$ & $\mathbf{G}$ & $\mathbf{G}$ & G & $G$ & $\mathbf{P}$ & $\mathbf{G}$ & $P$ & $\mathbf{P}$ & $\mathbf{P}$ & $\mathbf{P}$ & $\mathbf{G}$ & $\mathbf{G}$ \\
\hline \multicolumn{14}{|l|}{ Riser walk down } \\
\hline Avallable riser & 12 & 11 & 13 & 11 & 11 & 8 & 5 & 6 & 7 & 6 & 7 & 7 & 7 \\
\hline Risers near entr & 6 & 6 & 6 & 6 & 6 & 4 & 2 & 4 & 4 & 3 & 3 & & \\
\hline Status & $\mathbf{N}$ & $\mathbf{N}$ & $\mathbf{N}$ & $\mathbf{N}$ & $\mathbf{N}$ & $w$ & $\mathbf{N}$ & $\mathbf{N}$ & $\mathbf{N}$ & $N$ & $\mathbf{N}$ & $\mathbf{N}$ & $\mathbf{N}$ \\
\hline Activennactive & 1 & 1 & 1 & A & A & 1 & A & I & 1 & A & A & 1 & 1 \\
\hline
\end{tabular}



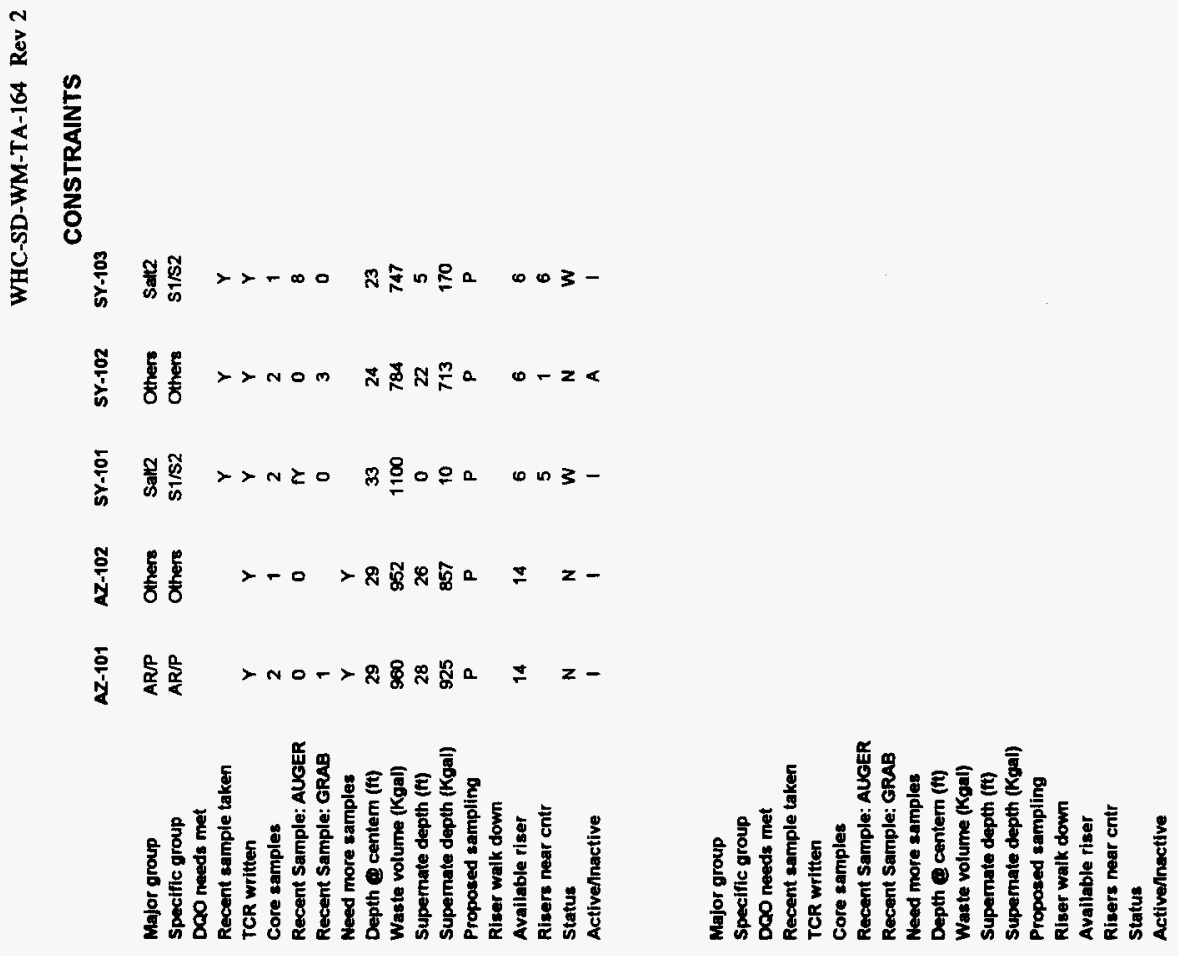


\section{DISTRIBUTION SHEET}

\begin{tabular}{|c|c|c|c|c|c|}
\hline \multirow{2}{*}{$\begin{array}{l}\text { To } \\
\text { Distribution }\end{array}$} & \multirow{2}{*}{\multicolumn{3}{|c|}{$\begin{array}{l}\text { From } \\
\text { Evaluation and Planning/TWRS } \\
\text { Technical Basis }\end{array}$}} & \multicolumn{2}{|l|}{ Page 1 of 2} \\
\hline & & & & \multicolumn{2}{|c|}{ Date $\quad 07 / 31 / 96$} \\
\hline \multicolumn{4}{|l|}{ Project Title/Work Order } & \multicolumn{2}{|l|}{ EDT No. N/A } \\
\hline WHC-SD-WM-TA-164, Rev. & Naste Charac & $n$ & $"$ & \multicolumn{2}{|c|}{ ECN No. ECN-631599 } \\
\hline Name & MSIN & $\begin{array}{c}\text { Text } \\
\text { With } \\
\text { All } \\
\text { Attach. }\end{array}$ & Text onls & $\begin{array}{l}\text { Attach./ } \\
\text { Appendix } \\
\text { Oniy }\end{array}$ & $\begin{array}{c}\text { EDT/ECN } \\
\text { Only }\end{array}$ \\
\hline
\end{tabular}

ONSITE

U. S. Department of Energy -

Richtand Field office

W. Liou

J. F. Thompson

N. W. Willis

S7 $-54 \quad x$

$\begin{array}{ll}57-54 & x \\ 57-54 & x\end{array}$

ICF Kaiser

R. L. Newe 17

$R$. T. Steen

S3-10 $\quad x$

Pacific Northwest National Laboratories
A. M. Liebetrau
J. L. Huckaby
K. M. Remund
K. D. Wiemers

$K 5-12 \quad X$

K6-80 X

K5-12 $\quad x$

$K 6-51 \quad X$

Westinghouse Hanford Company
M. R. Adams
H. Babad
R. F. Bacon
D. L. Banning
W. B. Barton
G. R. Bloom
T. M. Brown (20)
J. G. Burton
L. L. Buckley
J. W. Cammann
R. J. Cash
J. M. Conner
G. T. Dukelow
S. J. Eberlein
L. F. Ermold
D. W. Hamilton
C. S. Homi
J. O. Honeyman
J. W. Hunt
L. Jensen
G. D. Johnson

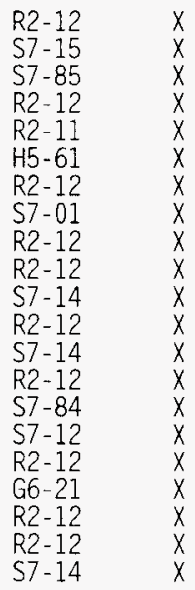




\section{DISTRIBUTION SHEET}

\begin{tabular}{|c|c|c|c|c|c|}
\hline To & \multirow{2}{*}{\multicolumn{3}{|c|}{$\begin{array}{l}\text { From } \\
\text { Evaluation and Planning/TWRS } \\
\text { Technical Basis }\end{array}$}} & \multicolumn{2}{|c|}{ Page 2 of 2} \\
\hline Distribution & & & & \multicolumn{2}{|c|}{ Date } \\
\hline \multicolumn{4}{|l|}{ Project Title/Work Order } & \multicolumn{2}{|c|}{ EDT No. $\quad N / A$} \\
\hline WHC-SD-WM-TA-164. Rev. & aste Characte & ization & sis" & \multicolumn{2}{|c|}{ ECN No. ECN-631599 } \\
\hline Name & MSIN & $\begin{array}{l}\text { Text } \\
\text { With } \\
\text { All } \\
\text { Attach. }\end{array}$ & Text Only & $\begin{array}{l}\text { Attach./ } \\
\text { Appendix } \\
\text { On } 7 y\end{array}$ & $\begin{array}{c}\text { EOT/ECN } \\
\text { Oniy }\end{array}$ \\
\hline
\end{tabular}

Westinghouse Hanford Company - continued

T. J. Kelley

N. W. Kirch

E. J. Kosiancic

J. G. Kristofzski

M. J. Kupfer

R. E. Lerch

E. J. Lipke

D. J. McCain

J. E. Meacham

C. T. Narquis

M. A. Payne

R. S. Popielarczyk

B. C. Simpson

J. P. Sloughter

G. A. Stanton, Jr.

J. E. Truax

A. M. Umek

D. J. Washenfelder

Central files

T.C.R.C. (1)

$\begin{array}{ll}\text { S7-21 } & x \\ \text { R2-11 } & x \\ \text { H5-61 } & x \\ \text { R2-12 } & x \\ \text { H5 -27 } & x \\ \text { S7-85 } & x \\ \text { A2-34 } & x \\ \text { R2-12 } & x \\ \text { S7-14 } & x \\ \text { T6-16 } & x \\ \text { S7-84 } & x \\ \text { A2-34 } & x \\ \text { R2-12 } & x \\ \text { R2-54 } & x \\ \text { S7-21 } & x \\ \text { R2-50 } & x \\ \text { S7 }-81 & x \\ \text { H5 }-27 & x \\ \text { A3-88 } & x \\ \text { R2-12 } & x\end{array}$

\section{OFFSITE}

U. S. Department of Energy - Headquarters

Office of Environmental Restoration and Waste Management EM-563

12800 Middlebrook Road

Germantown. MD 20874

K. T. Lang

J. A. Poppiti

$x$

$x$

Los A7 amos National Laboratory

P. 0 . Box 1663

Los Al amos. NM 87545

Stephen Agnew Group

SAIC

20300 Century BTvd.

Germantown. MD 20874

H. Sutter 